UNIVERSIDADE DE SÃO PAULO

FACULDADE DE FILOSOFIA, LETRAS E CIÊNCIAS HUMANAS DEPARTAMENTO DE HISTÓRIA PROGRAMA DE PÓS-GRADUAÇÃO EM HISTÓRIA SOCIAL

\title{
INVENÇÕES DO ACRE: DE TERRITÓRIO A ESTADO - UM OLHAR SOCIAL...
}

Maria José Bezerra 


\title{
UNIVERSIDADE DE SÃO PAULO \\ FACULDADE DE FILOSOFIA, LETRAS E CIÊNCIAS HUMANAS \\ DEPARTAMENTO DE HISTÓRIA PROGRAMA DE PÓS-GRADUAÇÃO EM HISTÓRIA SOCIAL
}

\section{INVENÇÕES DO ACRE: DE TERRITÓRIO A ESTADO - UM OLHAR SOCIAL...}

\author{
Maria José Bezerra
}

Tese apresentada ao Programa de Pós-Graduação em História Social, do Departamento de História da Faculdade de Filosofia, Letras e Ciências Humanas da Universidade de São Paulo para obtenção do título de Doutora em História.

Orientado: Prof. Dr. Ulysses Telles Guariba Neto 
Ficha Catalográfica

(Elaborada na Biblioteca Central da UFAC)

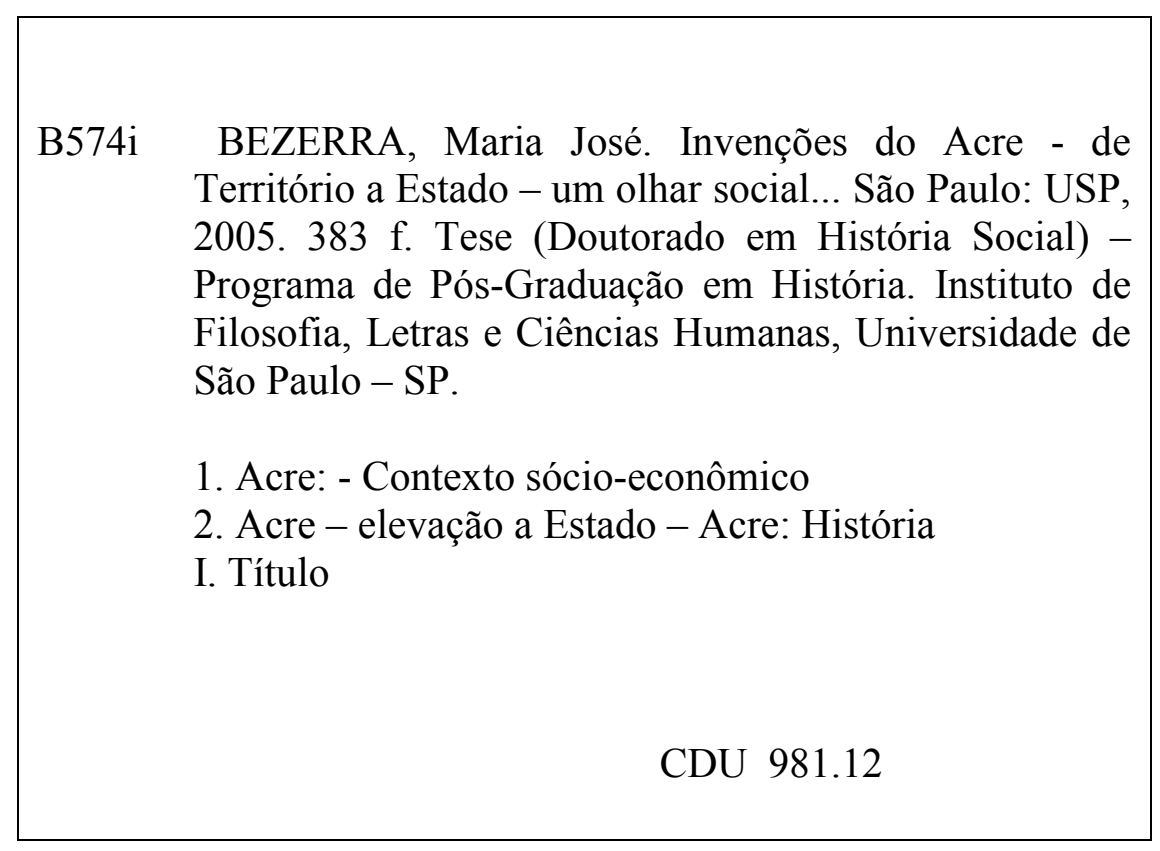




\section{DEDICATÓRIA}

A Luanda, elo de amor que me une ao Acre. A Eduardo Mansour pelo amor não vivido e a certeza do reencontro na outra dimensão da vida.

À memória de José Guiomard dos Santos, arauto da autonomia acreana.

Aos homens e mulheres de ontem e de hoje, que lutaram e lutam por um Acre autônomo e viável. 


\section{AGRADECIMENTOS}

Não teria sido possível produzir este trabalho sem o apoio e o reconhecimento às contribuições de tantas pessoas. Assim, agradecemos:

A Deus, por sua proteção e fidelidade permanentes em minha vida, dando-me forças para finalizar a redação desta tese.

A minha filha Luanda, pelas ausências e dilatada paciência durante a feitura deste trabalho acadêmico.

À Prof ${ }^{\mathrm{a}}$. Dr ${ }^{\mathrm{a}}$. Sandra Tereza Cadiolli Basílio, e, em especial seu irmão Walter pelo apoio inicial em São Paulo viabilizando a nossa inscrição no exame de seleção para o doutorado em História da USP.

Ao Prof. Dr. Ulysses Telles Guariba Neto, nosso orientador, pelas contribuições valiosas ofertadas.

Ao Prof. Dr. Francisco Murari Pires, pelo suporte intelectual às minhas atividades acadêmicas iniciais na USP e apoio fraternal durante a feitura da presente tese.

Ao Prof. Dr. Marcos Silva, pela leitura e aprovação da primeira versão do projeto do estudo realizado e sugestões ofertadas no exame de qualificação da tese.

Ao Prof. Dr. Valdir de Oliveira Calixto, pelas oportunas sugestões ao presente texto.

Ao Prof. Dr. Carlos Alberto Alves de Souza, pelas conversas elucidatórias mantidas ao longo da produção deste texto.

À minha mãe, D. Zefinha (in memoriam), por ter acalentado, há muitos anos, junto comigo, o sonho deste doutorado.

Ao meu pai, "o general do povo", José Sátiro Bezerra (Pilar), in memoriam, por me ensinar desde a tenra idade a ser cidadã.

A Gustavo Fernandes de Souza Ribeiro do Vale, o Gu, pelo carinho de filho durante as minhas estadas em Sampa, e a sua tia Nilda, pelos incentivos no decorrer da produção da tese.

À memória de madrinha Georgina, tia Cleonice e tio João, pelo orgulho de tê-los como remanescentes das minhas negras raízes.

Aos autonomistas do Acre, homens e mulheres, pela luta em prol de um Acre autônomo.

A Bety Cameli, pelo acesso a documentos importantes para o presente trabalho.

À Prof ${ }^{a}$. Dr ${ }^{\mathrm{a}}$. Rosa Ester Rossini, pelo companheirismo acadêmico e participação na banca de qualificação desta tese.

A Renée Grazia Salermo, pelos bons momentos em Sampa.

À memória de Lydia Hammes Guiomard dos Santos pelo incentivo à realização deste trabalho.

À memória de Rui Brandão, pelo sonho conjunto acalentado de escrever a história do Estado do Acre.

Aos entrevistados, homens e mulheres, que ousaram sonhar com um Acre emancipado e viável.

À memória da Prof . Maria de Lourdes de Lima Ramos (Lula Ramos), pelo exemplo de dedicação ao magistério superior.

A Clara Bader e Glória Queiroz, pela amizade, bálsamo necessário diante das vicissitudes da vida.

À memória de D. Massu e Seu Bio, amigos que me apoiaram ao longo da trajetória intelectual. 
Ao IESACRE, nas pessoas do diretor Sérgio Guimarães da Costa Flórido e vicediretor José Viana, pelo apoio imprescindível durante a pesquisa e redação final da tese.

Aos colegas e alunos da UFAC e IESACRE e aos pesquisadores do C.D.I.H., pelo acesso a documentos relevantes ao presente estudo.

A Marcos Vinícius Simplício das Neves, ex diretor do Patrimônio Histórico e Cultural da Fundação Elias Mansour e atual presidente da Fundação Garibaldi Brasil, pela amizade que nos une e paixão pela história acreana.

Aos funcionários do Museu da Borracha, pela acolhida durante as minhas pesquisas.

A Martiniano Cândido Siqueira Filho, pelos cuidados com a nossa filha durante as minhas idas a São Paulo.

As minhas secretárias do lar, Sônia e Vânia, pelo apoio nas atividades domésticas liberando-me para a feitura desta tese.

A Maria Lenice da Silva Lima, pela digitação do texto.

Ao colega de Academia, prof. de inglês Rosenato Pontes Corrêa pelo suporte na tradução do resumo.

A Beneilton da Silva Damasceno, pela criteriosa revisão textual.

A todos que, direta ou indiretamente, apoiaram este trabalho. 
"Sou, portanto, neste momento a voz dos heróis infelizes que nos deram o Acre, à custa de todos os sacrificios, inclusive o da própria vida; daqueles cearenses audaciosos que, tangidos pela seca e ao arrepio das caudais, alcançaram os confins da Pátria, descrevendo já em pleno século 20, novo drama de bandeirismo, na luta feroz com a vastidão amazônica; daqueles demarcadores de fronteiras que se rebelaram contra os gabinetes e as intrigas da cidade, sofrendo injustiças e admoestações, como no dizer do Thaumaturgo de Azevedo, "por cumprir deveres além do meu dever".

E, finalmente, tenho de falar em nome dos soldados provisórios apodrecidos nos igapós a fim de que a espada vitoriosa de Plácido de Castro [fosse] a expressão mais forte da nossa vontade de ser uma grande nação."

Discurso proferido por José Guiomard dos Santos na sessão da Câmara Federal, em 17 de novembro de 1953, em nome da Maioria. 


\section{SUMÁRIO}

Relação das Fotos

Relação dos Quadros

Relação das Abreviaturas

Resumo

Abstract

A INVENÇÃO DO ACRE ESTRANGEIRO - A GUERRA NOS ALTOS RIOS DO AQUIRY (INTRODUÇÃO)

1. Capítulo: A INVENÇÃO DO ACRE BRASILEIRO 82

1.1 Os que mandavam

1.2 E a borracha sustentava o Acre

1.3 Autonomia já!

2. Capítulo: A INVENÇÃO DO ACRE EMANCIPADO 140

2.1 O Acre quer ser Estado

142

2.2 E mulheres foram à luta - as legionárias do Acre

3. Capítulo: OS PARTIDOS POLÍTICOS E A MEMÓRIA DOS MILITANTES ACREANOS

3.1 Os partidos políticos brasileiros em foco

3.2 A voz do passado - os militantes acreanos

4. Capítulo: A INVENÇÃO DO ACRE VIÁVEL 230

4.1 O grito da floresta

253

4.2 A floresta envergonhada e as novas representações da autonomia acreana

277

OS LABIRINTOS DAS INVENÇÕES DO ACRE (CONCLUSÃO) 295

$\begin{array}{ll}\text { REFERÊNCIAS BIBLIOGRÁFICAS } & 301\end{array}$

$\begin{array}{ll}\text { GLOSSÁRIO } & 310\end{array}$

$\begin{array}{ll}\text { ANEXOS } & 319\end{array}$

ANEXO A - Tratado de Petrópolis (em português e espanhol) 320

ANEXO B - Tratado Velarde - Rio Branco 334

ANEXO C - Projeto 2.654-C/57 - Na Câmara dos deputados 343

ANEXO D - Discurso do Primeiro Governador constitucional do Acre, José Augusto de Araújo $\quad 346$

ANEXO E - Primeira Constituição do Estado do Acre 358 


\section{RELAÇÃO DAS ABREVIATURAS}

ADEP

BANACRE

BASA

CCAW

$\mathrm{CCC}$

CEBS

CEDB

CERB

CIMI

COBAL

CONTAG

COPERBO

CPT

DNI

FABOR

FPN

FUNTAC

IAHP

IBAD

INCRA

IPES

LIDER

MTR

PCB

$\mathrm{PC}$ do $\mathrm{B}$

PDT

PL

POLOAMAZÔNIA
- Ação Democrática Popular

- Banco do Estado do Acre

- Banco da Amazônia S.A.

- Comissão de Controle dos Acordos de Washington

- Comando de Caça aos Comunistas

- Comunidades Eclesiais de Base

- Comissão Executiva de Defesa da Borracha

- Colégio Estadual de Rio Branco

- Conselho Missionário Indigenista

- Companhia Brasileira de Alimento

- Confederação Nacional dos Trabalhadores Agrícolas

- Companhia Pernambucana de Borracha Sintética

- Comissão Pastoral da Terra

- Departamento Nacional de Imigração

- Fábrica de Borracha Sintética da Petrobrás

- Frente Parlamentar Nacional

- Fundação de Tecnologia do Acre

- Instituto Arqueológico e Histórico de Pernambuco

- Instituto Brasileiro de Ação Democrática

- Instituto de Colonização e Reforma Agrária

- Instituto de Pesquisas e Estudos Sociais

- Liga Democrática Radical

- Movimento Trabalhista Renovador

- Partido Comunista Brasileiro

- Partido Comunista do Brasil

- Partido Democrático Trabalhista

- Partido Liberal

- Programa dos Pólos de Desenvolvimento Agropecuário e Agromineral da Amazônia.

POLONORDESTE - Programa de Desenvolvimento Integrado do Nordeste Brasileiro 


$\begin{array}{ll}\text { PPS } & \text { - Partido Popular Sindicalista } \\ \text { PROBOR } & \text { - Programa de Incentivo à Produção da Borracha Vegetal. } \\ \text { PROTERRA } & \text { - Programa de Redistribuição de Terras e de Estímulo a Agroindústria } \\ & \text { do Norte e do Nordeste } \\ \text { PRT } & \text { - Partido Reformador Trabalhista } \\ \text { PSB } & \text { - Partido Socialista Brasileiro } \\ \text { PSD } & \text { - Partido Social Democrático } \\ \text { PT } & \text { - Partido dos Trabalhadores } \\ \text { PTB } & \text { - Partido Trabalhista Brasileiro } \\ \text { PTN } & \text { - Partido Trabalhista Nacional } \\ \text { PV } & \text { - Partido Verde } \\ \text { SESP } & \text { - Serviço Especial de Saúde Pública } \\ \text { SUDAM } & \text { - Superintendência do Desenvolvimento da Amazônia } \\ \text { SUDHEVEA } & - \text { Superintendência da Borracha } \\ \text { TORMB } & - \text { Taxa de Organização e Regulamentação do Mercado da Borracha } \\ \text { UDN } & \text { - União Democrática Nacional } \\ \text { UDR } & \text { - União Democrática Ruralista } \\ \text { UNI } & \text { União das Nações Indígenas }\end{array}$




\section{RELAÇÃO DAS FOTOS}

Foto 1 - Solenidade de assinatura da Lei 4.070, que elevou o Acre a Estado. Da esquerda para a direita: Lydia Hammes Guiomard dos Santos, José Guiomard dos Santos, Presidente João Goulart e o PrimeiroMinistro Tancredo Neves.15 de junho de 1962. Acervo: C.D.I.H.

Foto 2 - Presidente João Goulart assinando a Lei 4.070, de 15 de junho de 1962. Acervo: C.D.I.H. 


\section{RELAÇÃO DOS QUADROS}

Quadro 1 - $\quad$ Borracha exportada de 1822 a $1910 \quad 26$

Quadro 2 - $\quad$ Borracha exportada do Brasil 27

Quadro 3 - $\quad$ Valores das exportações (impostos alfandegários) 28

Quadro 4 - $\quad$ Emigração para a Amazônia 29

Quadro 5 - $\quad$ Produção da borracha em $1950 \quad 122$

Quadro 6 - $\quad$ Produção da borracha no Alto Purus - $1952 \quad 122$

Quadro 7 - $\quad$ Produção da borracha na zona do Alto Juruá 123

Quadro 8 - $\quad$ Produção da castanha (1920-1950) 124

$\begin{array}{lll}\text { Quadro } 9 \text { - } & \text { A madeira no Acre } & 126\end{array}$

Quadro 10 - $\quad$ Exportação da borracha (1945-1952) 128

Quadro 11 - $\quad$ Produção e consumo da borracha 237

Quadro 12 - $\quad$ Borracha sintética: produção, importação e consumo no Brasil, (1960 a 1970)

Quadro 13 - $\quad$ Produção da borracha natural 242 


\section{RESUMO}

A presente tese de doutorado "INVENÇÕES DO ACRE - DE TERRITÓRIO A ESTADO - UM OLHAR SOCIAL. . .” tem como objetivo central caracterizar o processo histórico de invenção do Acre em quatro momentos decisivos, a saber: o Acre estrangeiro, o Acre brasileiro, o Acre emancipado e o Acre viável.

Como parte do objetivo explicitado destacam-se, também, questões relativas aos seguintes aspectos:

a) o processo de anexação do Acre ao território nacional;

b) a luta pela emancipação política do Acre;

c) a participação das mulheres na luta emancipacionista acreana;

d) a memória dos militantes políticos acerca do Acre-Estado; e

e) as novas representações do Acre.

Acrescentamos, ainda, que para a elaboração do presente trabalho utilizamos como fontes os depoimentos de seringueiros/seringueiras, das mulheres integrantes da "Legião Acreana" e dos militantes políticos do Acre, artigos dos jornais "O Acre" e "O Estado", livros, relatórios de prefeitos e governos do Acre, fotografias, coletâneas de documentos oficiais acerca da anexação do Acre ao Brasil, bem como alusivos à tramitação do processo de elevação do Acre a Estado, entre outros.

A meta perseguida foi descrever as invenções do Acre, a partir de um "olhar" social, destacando sujeitos sociais não contemplados pela história oficial, tendo como horizonte demonstrar o custo social das referidas invenções para os segmentos subalternos.

PALAVRAS CHAVES: Acre - anexação ao Brasil. 2. Acre. - Elevação a Estado. Acre: história. 


\begin{abstract}
The purpose of this doctoring thesis "Inventions of Acre - from territory to State - a social looking", has the central objective to characterize the historic process of invention of Acre in four decisive moments, to know: The foreigner Acre, The brazilian Acre, the Emancipated Acre and the Viable Acre.
\end{abstract}

As part of the explicitated objective detach, also, questions relating to the following aspects:

a) The process of anexation of Acre to the nacional territory;

b) The fighting for politic emancipation of Acre;

c) The participation of the Acreana women in the emancipationist fighting;

d) The memory of the militant politicians about Acre-State; and

e) The new representation of Acre.

We add yet, that for the elaboration of the present work we utilized as font the reportings of the rubbertappers, of the Legião Acreana women and the militant politicians of Acre, and articles from Acre and State journals, books,reportings

From mayors and governs of Acre, photos, collectanea of official documents about the anexation of Acre to Brazil, as well as allusive to the transmition of the elevation process of Acre to state, among others.

The persecuted aim was to describe the inventions of Acre, from a social looking, detaching social subjects not comtemplated by the official history, taking as horizon to demonstrate the social cost of the reffering inventions for the subaltern classes.

Key words: Acre - Anexation to Brazil. Acre- Elevation to state. Acre: - history. O ACRE ESTRANGEIRO - a guerra nos altos rios do Aquiri (INTRODUÇÃO) 


\section{O ACRE - ESTRANGEIRO - A GUERRA NOS ALTOS RIOS DO AQUIRI (INTRODUÇÃO)}

A guerra e a diplomacia são pedras que no tabuleiro internacional se combinam segundo as circunstâncias e certas regras de um grande jogo A condução dos povos ao seu destino!

José Guiomard dos Santos

A presente tese de doutorado "Invenções do Acre - de Território a Estado - um olhar social. ..” tem como objetivo central caracterizar as invenções do Acre em quatro momentos decisivos de sua história, a saber o Acre estrangeiro, o Acre brasileiro, o Acre emancipado e o Acre viável numa perspectiva histórica institucional que possibilita o diálogo entre fontes históricas oficiais e as memórias e oralidades de atores sociais presentes em cada momento inventivo, trazendo estes à cena histórica com suas vozes, experiências, esperanças, aventuras e desilusões, no entendimento de que a legitimidade dos discursos presentes nos relatos não está tanto na excepcionalidade do conteúdo de suas falas, mas no que elas permitem desvelar por apresentar contextos novos em relação aos documentos oficiais.

Portanto, uma história documentada institucionalmente, mas, também, centrada na experiência de sujeitos sociais subalternos. Uma história que apresenta o diálogo com o "outro" ou sobre o "outro" e neste contexto, enquanto pesquisadora, a partir do nosso lugar social de origem e das experiências vividas como migrante nesses vinte e um anos de Acre, nos colocamos como parte integrante da história contada.

Nesse processo, nos enxergamos entre os "outros", nos colocamos no tempo deles e nos nossos, e todos nós numa viagem no tempo, numa história que é diacrônica e sincrônica.

A meta almejada foi construir uma escrita da história onde o pulsar da vida dos atores sociais esteja presente, incorporando a emoção do vivido. Objetividade não se configura como 
neutralidade e nem como isenção histórica. A história pode e deve trazer à baila a emoção do vivido.

Como chegamos ao tema?

A escolha do tema, os cortes temporais e as abordagens descritas foi um processo que teve início no começo da década de 1990, quando na condição de Coordenadora do Centro de Documentação e Informação Histórica (CDIH) da UFAC, tive a oportunidade de organizar o acervo documental alusivo ao tema, publicando em 1993 o "Dossiê-Acervo: Guiomard Santos (Acre) Elevação do Acre a Estado”, o qual se constitui uma coletânea de documentos de natureza diferenciada, cronologicamente seqüenciada de 1953 a 1962, exceto nos casos dos documentos sem data.

A partir dessa época, começamos a desenvolver estudos sobre o tema em foco, inclusive coordenamos, juntamente com o prof ${ }^{\circ}$. Dr. Valdir de Oliveira Calixto, um projeto de pesquisa através do PIBIC.

Importante considerarmos também que a facilidade de acesso a documentação referente à transição do Acre de Território a Estado deve-se ao fato de que, em 1987, a sra. Lydia Hammes Guiomard Santos doou à UFAC o acervo da biblioteca do ex-governador José Guiomard Santos, bem como a amizade pessoal que desenvolvemos com ela, fazendo com que, nas suas vindas a Rio Branco, tivéssemos oportunidade de entrevistá-la acerca do assunto.

Outro aspecto que nos guiou ao assunto foi o fato de que até o presente não há nenhum trabalho acadêmico sobre a elevação do Acre a Estado, sendo o tema tratado como apêndice de algumas dissertações de mestrado e teses de doutorado. E, nesse sentido, a intenção acalentada foi oferecer contributos quanto a construção de um tempo histórico ainda desconhecido, na medida que tanto os trabalhos dos historiadores quanto de sociólogos, antropólogos e economistas acerca do Acre têm priorizado em seus estudos o corte temporal 
de 1970 aos dias atuais. Ou em casos esporádicos, das últimas década do século XIX até o final da década de 1940, do século XX.

Inicialmente pretendíamos limitar à invenção do Acre ao período de 1953 - 62, porém, ao avançarmos as pesquisas, decidimos trabalhar os quatro momentos significativos das invenções do Acre e, neste caso, extrapolamos o marco temporal previsto, atingindo a década de 1990.

Por que $1953 ?$

Em 1953, durante as solenidades do cinqüentenário do Tratado de Petrópolis, José Guiomard dos Santos proferiu um discurso na Câmara Federal, no qual assumiu publicamente que, enquanto parlamentar, iria lutar pela emancipação política do Acre, elaborando um projeto que encaminharia ao Congresso Nacional. Nessa direção, em 1954, apresentou a primeira versão do projeto, que ao longo de sua tramitação foi sofrendo ajustes até ser aprovado em 15 de junho de 1962, através da Lei n. 4.070.

E, por último, ressaltamos que a presente tese dá continuidade aos estudos que iniciamos durante o Mestrado, quando discutimos a construção do imaginário de Rio Branco como cidade, durante a gestão de Guiomard Santos como governador do Acre-Território, no período de $1946-50$.

Como suporte teórico às reflexões presentes nesta tese, utilizamos as contribuições de Antônio Gramsci acerca dos conceitos de elite e intelectuais orgânicos, categorias fundamentais ao entendimento da relação entre Guiomard Santos e os representantes dos patrões (seringalistas e comerciantes), instrumentalizando-os quanto às estratégias para a corporificação e aprovação do projeto de Estado gestado por estes.

As reflexões de Michel Foucault seja acerca de discurso, seja quanto a microfísica do poder também nos foram úteis, particularmente quando ele discute a não-compartimentação e determinação entre as esferas política, econômica, social e cultural, além do fato de que a 
compreensão das invenções do Acre exige relacionar o local ao nacional e internacional de maneira articulada. E a questão dos poderes, pois o poder não está concentrado exclusivamente no Estado, sendo este um mero aparelho de dominação da classe dominante, na medida que a luta pela elevação do Acre à condição de Estado, apesar das estratégias e alianças engendradas pelos representantes da classe produtora, não foi vitoriosa no primeiro pleito para a eleição do também primeiro governador do Acre Constitucional, o que se comprova com a eleição de José Augusto de Araújo para o governo do Acre - Estado. As forças políticas que "fizeram" o Estado não receberam o apoio popular para governá-lo.

Por outro lado, a luta pela autonomia do Acre não ocorreu sem resistências dentro da própria rede do poder, frente a multiplicidade de relações de forças engendradas, podendo ter havido uma relativa autonomia da periferia em relação ao centro.

No sentido de entendermos o universo ideológico e as práticas políticas de José Guiomard dos Santos e Oscar Passos, ambos pertencentes às esferas do Exército Brasileiro, as contribuições de Caio Navarro de Toledo quanto ao ISEB e o seu papel na formulação da ideologia nacional-desenvolvimentista foram fundamentais.

Considerando, ainda, que o movimento autonomista se desenvolveu num universo marcado pela luta do poder local para se afirmar frente ao "poder central", as contribuições de Suely Robles acerca dos "radicais da República" e Maria Isaura Pereira de Queiroz sobre o mandonismo local na vida política brasileira nos ajudaram a compreender as peculiaridades dos "coronéis de barranco". A este respeito, algumas obras da literatura e da historiografia acreana também foram importantes.

Para o estudo do acreanismo subjacente à questão autonomista, as ponderações de Eric Hobsbawn sobre tradição e, ainda, as que se referem aos séculos XIX e XX, contribuíram, sobremaneira, para a contextualização do nosso objeto - as invenções do Acre. 
Em relação à memória política dos integrantes dos partidos políticos da época - PSD, PTB e UDN - e à memória social das mulheres legionárias da causa autonomista, os trabalhos de Eclea Bosi e Maurice Halbwachs foram imprescindíveis quanto à relação entre memória, história e identidade.

A documentação a que tivemos acesso é bastante ampla e diversificada. Comporta depoimentos orais, relatórios de prefeitos departamentais e governadores do Acre, fotografias antigas, dossiê sobre a elevação do Acre a Estado, o projeto de elevação do Acre a Estado nas suas três versões, os jornais "O Acre" e "O Estado" de 1953 a 1962, e o jornal alternativo Varadouro de 1977 a 1981.

Frente ao exposto, o presente trabalho tem como objetivo central historiar o processo das invenções do Acre, em vários momentos, dando ênfase aos homens e mulheres que bravamente lutaram, primeiramente, por um Acre brasileiro, depois por um Acre emancipado politicamente e, na atualidade, lutam por um Acre viável.

Com base no exposto, outro aspecto a considerar é que as invenções do Acre tiveram como pano de fundo o processo do desenvolvimento do capitalismo, a partir das últimas décadas do século XIX, quando teve início a ocupação efetiva das terras, onde atualmente localiza-se o Acre, por migrantes nordestinos, notadamente cearenses. E, nesse contexto é importante considerarmos que os povos indígenas foram os primeiros ocupantes do Acre.

E, por que as terras onde atualmente localiza-se o Acre pertenciam a Bolívia?

A invenção do Acre estrangeiro liga-se a expansão européia no continente americano, especialmente aos Tratados internacionais entre Portugal e Espanha na disputa por terras, assim o primeiro instrumento legal definidor das terras de um e de outro foi a Bula Intercostera de 1493, pois esta determinou que o marco divisor das terras de ambos seria 100 léguas da Ilha de Cabo Verde, ou seja as terras que estivessem a oeste desta linha imaginária pertenceriam a Espanha e as que ficassem a leste seriam de Portugal. 
Dessa forma, não só a área territorial do Acre, mas a Bolívia pertenciam a Espanha.

Com o Tratado de Tordesilha, o quadro não se inverteu, pois este estabelecia que a 370 léguas a oeste da Ilha de Cabo Verde, as terras pertenceriam a Espanha e a leste a Portugal. Nesse caso, Acre e Bolívia continuam nos domínios da Espanha na América.

Com o Tratado de Madri, datado de 1750 ficou estabelecida que os portugueses assegurariam para si as terras já "adquiridas" na Amazônia, tendo como base o princípio do UTI POSSIDETIS, mesmo assim Acre e Bolívia continuariam sob o domínio da Espanha.

Em 1761, com o Tratado Pardo, ficou acordado que os limites das terras entre Portugal e Espanha na América deveriam ser os já previstos pelo Tratado de Tordesilhas de 1494. Dessa forma, o status do Acre e o de Bolívia não se alteraram pois continuam a pertencer a Espanha.

Por sua vez, o Tratado de Santo Idelfonso de 1777, estabeleceu que os territórios, até então, conquistados pelos portugueses na Amazônia pertenceriam a Portugal, e, dessa forma chegou-se ao tratado de Ayacucho de 1867, assinado no contexto da Guerra do Paraguai, o qual se propôs a atender as reivindicações da Bolívia em relação ao Acre, desde que esta se comprometesse a ficar neutra no conflito.

Portanto, a dança das linhas de limites entre Portugal e a Espanha conduziram ao Tratado de Ayacucho assinado em 1867, através do qual, a Bolívia tornou-se proprietária formal das terras do atual Acre.

No entanto, embora a região pertencesse a Bolívia, a borracha estava sendo explorada exclusivamente por produtores brasileiros, e a Bolívia buscava participar das vantagens dessa produção.

Merece menção o fato de que a borracha tornava-se matéria prima emergente em decorrência do desenvolvimento industrial. 
Produto importante na pauta das exportações brasileiras, a borracha era produzida na região acreana e na crescente expansão de sua extração, a região do Acre ocupava posição de destaque, haja vista que tinha grande abundância de seringas da melhor qualidade.

No enfrentamento que passou a existir envolvendo o Brasil e a Bolívia, quanto à definição de suas fronteiras, a Bolívia, em várias reclamações ao governo brasileiro, solicitou maior brevidade na demarcação de limites, mormente a partir de 1895, quando, em atendimentos ao Protocolo de 19 de fevereiro, o governo brasileiro atendeu aos reclames dos bolivianos quanto à formação de uma Comissão Mista (Brasil - Bolívia) para solucionar a demarcação de limites entre os dois países.

Para a Bolívia, uma tomada de posição por parte do Brasil era vital para que aquele país atuasse nas atividades de produção e comercialização da borracha em seus territórios vales do rio Acre e Alto Purus, como também no vale do rio Juruá - e, dessa forma, incrementasse a sua economia através de maior participação no mercado internacional.

Inicialmente, as relações políticas entre as duas nações se realizaram num clima de amizade por meio de correspondências e acertos cordiais de "compreensão" recíproca aos direitos de cada uma na região.

A Bolívia, enfraquecida pela instabilidade política e debilidade econômica, aliada à falta de unidade territorial, não se encontravam em condições de pleitear com beligerância a posse da região.

Por outro lado, ficam patentes as dificuldades da Bolívia em enviar expedições à região para ocupá-la e explorá-la, além da própria carência de população disponível por parte da Bolívia para realizar o empreendimento de ocupar a área, bem como o fato das grandes dificuldades de transportes e comunicação diante de um território tão imenso e distante, sobretudo se levarmos em conta que os rios eram as principais vias de penetração na área. 
Por outro lado, se o meio físico, de um lado, dificultava a penetração boliviana, do outro facilitava a chegada dos brasileiros, que, saindo de Manaus, "poderiam chegar ao Acre 20 a 25 dias, na época da estiagem, e de 15 a 20 dias na época das cheias; 20 a 25 dias partindo de Belém; 25 a 30, saindo do Ceará ${ }^{1}$.

O fato é que as populações agrárias da Bolívia não imigraram para a região dos "gomales do Acre". Um documento da época da Revolução Acreana, assinado por D. Lino Romero, corrobora na afirmativa das diferenças climáticas entre Brasil e Bolívia, ao dizer que

[. . .] nos encontramos em pena lucha, talvez antes de dois dias seremos atacados en este puerto. . . Los que aun quedamos en el Acre, estamos dispostos a oferecer iguales sacrifícios e esa divindad simbólica que se llama Pátria.

Queremos evitar nuevos sacrifícios e nuestro desgraciado pais. El Acre nominalmente es de Bolívia; pero materialmente es de Brasil. Todo contribuy a elles; imensas distancias y obstáculos que os separam del resto del país la población extraña que lo puebla, la falta de vias de comunicación dentro del mismo território y finalmente la imposible adaptación de nuestra raza à este clima mortífero. Los bolivianos en esta región nos sentimos tan extraños como nos sentiríamos en las apartadas colonias del Ásia, además nos sou aqui adverso la naturaleza y los hombres [...]

Pueblos poderosos no han podido manejar bajo sus domínios a seres de otra raza y otros costumbres, y nosotros que somos um pueblo debil y embrionário, no podemos contrariar uma lei histórica comprobada a cada paso. $^{2}$

Este documento, escrito no calor dos acontecimentos que marcaram as últimas resistências das forças militares bolivianas quando cercadas por Plácido de Castro, patenteia nossas afirmações anteriores quanto aos obstáculos existentes à ocupação boliviana definitiva no Acre.

No entanto, o que foi decisivo para a ocupação das terras do Acre pelos brasileiros e litígio pela posse das terras entre Brasil e Bolívia foi, inegavelmente, o desenvolvimento industrial dos países europeus e dos E.U.A. e, conseqüente, a demanda internacional por borracha, e, do outro, a grande seca de 1877 que atingiu o Ceará.

\footnotetext{
${ }^{1}$ Ibid. p. 76.

${ }^{2}$ Ibid. p. 79.
} 
A exploração da borracha na Amazônia, inicialmente, desenvolveu-se no estado do Pará, incluindo as ilhas de Marajó e alguns municípios localizados às margens do Amazonas.

No entanto, frente ao processo arcaico de extração do látex, ocasionando o rápido esgotamento das árvores, havia uma necessidade crescente de penetração na floresta, notadamente nos rios da Bacia Amazônica.

$\mathrm{Na}$ primeira metade do século XIX, foram explorados os primeiros trechos do Amazonas acima, na incessante procura por novos mananciais de hévea.

Nessa época, a cotação da borracha no mercado internacional era alta e sua exportação, a partir de 1839, com a invenção de Goodyear, borracha vulcanizada, e, sobretudo, mais adiante, com o desenvolvimento da indústria de veículos e da fabricação de pneumáticos, atingiu patamares de significativas elevações, o que induzia a uma maior produção, que por sua vez demandava uma maior quantidade de mão-de-obra e de recursos financeiros.

O capital para a compra das mercadorias e equipamentos originou-se das poupanças dos empresários de Belém, de outras regiões brasileiras e de uma pequena parte de estrangeiros.

A mão-de-obra, em sua maioria, era proveniente da zona rural do Estado do Pará, que de tradição agrícola passou a dedicar-se ao extrativismo da borracha.

O método de extração do látex pela técnica arcaica que utilizava gerava o esgotamento das fontes produtoras do látex, que eram abandonadas, impelindo a procura de novos locais, o que levava à penetração cada vez maior do rio Amazonas acima.

Dessa forma, à medida que diminuía a produção do Pará, aumentava a produção do Amazonas. Esse fato impulsionava os governos do Pará e do Amazonas a penetrarem, cada vez mais, em direção aos rios acima, na Bacia Amazônica, que se expandia principalmente na direção oeste ou na direção dos territórios peruanos e bolivianos. 
Por volta de 1850 , objetivando abrir novas vias de comunicação e comercialização com a Bolívia, o governador do Amazonas incentivou a organização da expedição do pernambucano Serafim Salgado e o impeliu a subir os rios Aquiri (Acre) e Iaco.

Em 1858, outro explorador, João da Cunha Correia, subiu o rio Juruá, atingindo a foz do Juruá-Mirim em terras do Acre, embora julgasse haver atingido o rio Xapuri, no AltoAcre.

Mais adiante, em 1861, Manuel Urbano da Encarnação, através de outra expedição exploradora, atingiu a região acreana, ultrapassando as fronteiras do Brasil e penetrando nos rios Aquiri, Iaco e Chandless, em territórios conhecidos bolivianos. Essas expedições marcaram o início da ocupação das terras do Acre, tendo como via de penetração os rios.

No entanto, foi a partir de 1877, com a "grande seca" do Ceará, que se iniciou, de forma efetiva, a corrida migratória dos nordestinos, especialmente cearenses, para a Amazônia.

Afugentados de seus locais de origem tanto pelos horrores da seca quanto pela concentração fundiária que os transformava em "massa de manobra" dos grandes proprietários de terra do Nordeste, que os usavam e descartavam conforme seus interesses e "humores", e por outro lado atraídos pela perspectiva de que, vindo para a Amazônia, poderiam adquirir em pouco tempo capital suficiente para retornar ao Nordeste e comprar um pedaço de terra para "tocar a vida", os nordestinos lançaram-se ao sonho de um futuro promissor na Amazônia.

A construção desse imaginário da Amazônia como um paraíso, terra de abundância, onde as árvores, as seringueiras, davam "leite" que virava "ouro", fez com que milhares de nordestinos (cearenses, paraibanos, potiguares, piauienses, pernambucanos e outros), deixassem para trás o inferno da seca. 
Segundo Raimundo Girão, a emigração nordestina de 1869 até o fim do século XIX atingiu o total de 255.526 pessoas, tendo-se o porto de Fortaleza, capital do Ceará, como a principal via de partida para o Amazonas.

A esse respeito, o historiador Samuel Bechimol também assinala que, de 1877 a 1900, houve um grande fluxo migratório do Nordeste para a Amazônia, destacando, no período, o aumento triplicado de migração de 1877 a 1879, uma certa continuidade até 1892 e, de 1892 até 1898, um certo equilíbrio e uma nova onda crescente migratória de 1898 até 1900, devido à maior demanda de borracha.

Por outro lado, à medida que a indústria crescia, aumentava o nível de produção, que até então era realizado unicamente na Amazônia. Em decorrência da produção e exportação da borracha, desenvolveram-se o comércio e a importação de produtos estrangeiros para o abastecimento da região, que numa cadeia de dependência interligava as casas exportadoras às aviadoras e estas ao seringalista e ao seringueiro.

As atividades de importação e exportação eram realizadas através do transporte a vapor. Nesse aspecto, foram operadas melhorias nas embarcações, inclusive no que concerne a uma maior capacidade de tonelagem.

Importante destacar que os rios tiveram papel preponderante no comércio da borracha, entre os quais salientamos o Purus, o Acre, o Iaco e o Chandless, na bacia do Juruá (Tarauacá e o Envira) além do Madeira.

Por outro lado, o contrabando na região era intenso, proporcionando o enriquecimento dos comerciantes do Amazonas, pois o tratado de 1867 permitira à Bolívia o livre trânsito nos rios da Amazônia. Isso fez com que as mercadorias importadas com destino à Bolívia passassem livremente pelas alfândegas brasileiras e, em vez de seguirem seu destino, eram vendidas para o consumo do Amazonas. A borracha extraída do território brasileiro várias 
vezes vinha à exportação com guias das alfândegas bolivianas, furtando-se, assim, o interessado ao pagamento dos impostos devidos.

Embora fosse inegável o lucro dos Estados amazonenses, muitos contrabandistas conseguiram enriquecer desviando lucros que seriam totais para o Amazonas e o Pará.

No quadro seguinte, pode-se observar o aumento da exportação da borracha nas praças de Manaus e Belém no período de 1822 a 1901, embora grande parte dessa produção fosse oriunda do Acre boliviano.

\section{Quadro 1}

Borracha Exportada de 1822 a 1910

\begin{tabular}{lc}
\hline ANOS & TONELADAS \\
\hline 1822 & 156 \\
1830 & 388 \\
1840 & 1.467 (com a expansão da navegação) \\
1850 & 2.675 \\
1860 & 2.591 \\
1870 & 8.679 (com a seca e a grande imigração) \\
1880 & 16.394 \\
1890 & 27.650 \\
1900 (época litigiosa) & 38.177 \\
1910 &
\end{tabular}

Fonte: Serzedelle Corrêa. O Rio Acre. Rio de Janeiro: Casa Monty Alverne, 1899, p. 57 In: LIMA, Manoel Ferreira. A Bolívia de 1890 a 1905: suas relações exteriores e a questão do Acre, p. 86. 
Merece destaque o fato de que, até 1880 , a Bolívia não auferiu grande lucros com a borracha, exceto durante a ocupação da Delegacia de Paravicini e do delegado Lino Romero. A primeira ocorreu durante o período de 2 de janeiro de 1899 a 30 de abril do mesmo ano, quando foi instalada uma instância arrecadadora de impostos, atingindo a soma de quase cinco milhões de contos de réis. A segunda realizou-se no período de agosto de 1900 a agosto de 1901, ocasião em que novamente a Bolívia conseguiu o domínio da região.

Portanto, até essa fase, a produção de borracha comercializada pela Bolívia era inexpressiva e produzida na região do Departamento de Beni, sendo exportada pelo rio Madeira. Somente após o Tratado de Petrópolis (1903) é que a produção da borracha no Alto Acre e Abunã tornou-se mais significativa e, embora fosse explorada por mão-de-obra brasileira, era controlada por entidades fiscais bolivianas.

Assim, foi no contexto de fins do século XIX, particularmente na sua última década, que a borracha ganhou grande relevo nas exportações brasileiras, especialmente dirigidas para a Europa e os E.U.A, tendo este último um consumo maior.

\section{Quadro 2}

Borracha Exportada do Brasil de 1890 a 1898

\begin{tabular}{r|rc|rc}
\hline ANO & \multicolumn{2}{|c|}{ PARA A EUROPA } & \multicolumn{2}{c}{ PARA OS ESTADOS UNIDOS } \\
\hline 1890 & 6.806 .058 & toneladas & 9.687 .763 & toneladas \\
1891 & 6.957 .877 & “ & 10.831 .528 & “ \\
1892 & 7.077 .623 & “ & 11.341 .559 & “ \\
1893 & 7.785 .270 & “ & 11.431 .929 & “ \\
1894 & 9.012 .658 & “ & 10.461 .030 & “ \\
1895 & 9.518 .170 & “ & 11.251 .410 & “ \\
1896 & 12.556 .424 & “ & 9.045 .450 &
\end{tabular}


10.915 .742 “

12.078 .742

“

“

12.620 .858

66

1898

Comea. O Rio Acre.

9.830 .265

Fonte: Serzedello Corrêa. O Rio Acre. p. 160. In: LIMA, Manoel Ferreira. A Bolívia de 1890 a 1905: suas relações exteriores e a questão do Acre, p. 88.

Fazendo uma leitura do quadro acima, verificamos que as exportações resultaram em grandes lucros para as praças exportadoras e importadoras (Manaus e Belém).

\section{Quadro 3}

Valores das Exportações (impostos alfandegários)

\begin{tabular}{c|c|c}
\hline ANO & ALFÂNDEGA DE BELÉM & ALFÂNDEGA DE MANAUS \\
\hline 1893 & $11.487: 840 \$ 082$ & $3.929: 975 \$ 813$ \\
\hline 1894 & $13.281: 850 \$ 282$ & $3.809: 332 \$ 458$ \\
\hline 1895 & $13.447: 669 \$ 751$ & $5.476: 596 \$ 197$ \\
\hline 1896 & $18.507: 065 \$ 132$ & $5.831: 645 \$ 275$ \\
\hline TOTAIS & $56.724: 425 \$ 247$ & $19.047: 549 \$ 743$ \\
\hline
\end{tabular}

Fonte: Serzedello Corrêa. O Rio Acre. p. 161. In: LIMA, Manoel Ferreira. A Bolívia de 1890 a 1905: suas relações exteriores e a questão do Acre, p. 89.

Fica evidente que, com a produção da borracha, os Estados do Pará e do Amazonas (Grão-Pará e Rio Negro) buscaram se afirmar no contexto de construção da ordem republicana.

Belém, mais do que Manaus, tornou-se o principal pólo exportador da Amazônia, ficando o Amazonas com uma significativa parcela deste e nada para a Bolívia, que na época não tinha participação atuante nessa comercialização. 
Sob o impulso da economia gomífera, Belém e Manaus passaram a viver a sua "belle époque", cujas marcas estão presentes nas feições arquitetônicas e nos serviços urbanos instituídos. Foi a época dos anos dourados à moda européia, notadamente francesa.

Esse processo de crescimento da produção da borracha incentivou a migração para a Amazônia. Segundo Wagley, “o afluxo na Amazônia foi tão grande em fins do século XIX que a população de Manaus, que em 1879 era de 5.000 pessoas, em 1890 atingia 50.000, e em Belém, onde viviam apenas 15.000 pessoas em 1848 , em 1890 já se contavam $100.000^{3 \%}$.

Nesse processo migratório, a participação nordestina foi preponderante, pois no período de 1872 a 1900, conforme Celso Furtado, a população, que era de aproximadamente 260.000 habitantes, elevou-se para 500.000 no decênio daquele século.

Esses números são, por sua vez, questionados por outros autores como Benchimol, que propõe para esse mesmo período (até 1910) um contingente em torno de 300.000 pessoas. Nos cálculos de Girão, das 300.902 pessoas que emigraram do Ceará de 1869 até o fim do século, 225.526 se destinaram para a Amazônia.

Segundo Benchimol, conforme quadro abaixo, os percentuais quanto à emigração para a Amazônia foram menores, embora trabalhe com um período menor (1877 - 1900).

\section{Quadro 4}

Emigração para a Amazônia

\begin{tabular}{c|c}
\hline ANO & PESSOAS \\
\hline 1877 & 4.610 \\
1878 & 15.300 \\
1892 & 13.593 \\
1893 & 7.830
\end{tabular}

\footnotetext{
${ }^{3}$ WAGLEY, C. Uma comunidade Amazônia. Estudo do homem nos trópicos. 2 ed. São Paulo: Nacional, 1977, p. 62.
} 


\begin{tabular}{c|r}
1894 & 4.443 \\
1895 & 9.052 \\
1896 & 9.682 \\
1897 & 7.312 \\
1898 & 25.872 \\
1899 & 17.045 \\
1900 & 45.792 \\
Total Geral & 160.125
\end{tabular}

Fonte: MARTINELLO, Pedro. A Batalha da Borracha na Segunda Guerra Mundial e suas conseqüências para o Vale Amazônico, p. 42.

Pelos dados apresentados por Roberto Santos, podemos deduzir que a população da Amazônia aumentou de forma sensível no período de 1877 a 1910, distanciando-se muitos dos índices iniciais, quando, quadruplicando seu contingente populacional no período, apresentou em relação a outras regiões brasileiras um crescimento populacional dos mais expressivos.

Como parte do processo migratório, os migrantes que se dirigiram aos altos rios, ao Aquiri, fixaram-se às margens deles, dando origem aos seringais, que se tornaram unidades de produção da borracha e também cenário das lutas por um Acre brasileiro.

Essa ocupação da região do Aquiri representou um custo social para o migrante na condição de seringueiro, devido à instituição do regime de trabalho compulsório e o conseqüente endividamento. E, para os povos indígenas que ocupavam as terras do atual Acre, significou a expropriação e o genocídio.

A Bolívia, no afã de assegurar oficialmente seu domínio sobre ao altos rios do Aquiri, em 3 de janeiro de 1899, destituiu a autoridade dos funcionários brasileiros ali representados pelo superintendente Francisco Monteiro de Souza Júnior e pelo juiz de Direito da Comarca 
de Vila Amazonense de Floriano Peixoto anteriormente denominado município de Antimari, nomeados pelo governo daquele Estado.

Para que se tenha uma idéia do que era o Antimari, depois Floriano Peixoto, em fins do século XIX, a descrição de um personagem ilustre que habitava a área nos apresenta um cenário pungente da região.

Não possuía casa para a Intendência, não tinha cadeia e era tal a desordem que nem mesmo havia foro mais ou menos organizado, não havia cartório ou archivo de livros e documentos pertencentes às duas administrações judiciária e municipal, reinando em tudo um absoluto chaos. Nunca se reunira o Jury e os criminosos ou eram despronunciados (os que tinham dinheiro) ou ficavam na rua aumentando o número de vagabundos. A grande receita do Município, orçada sempre em 600 contos de réis, desaparecia como por encanto, sem que no lugar ficasse realizado o menor melhoramento ${ }^{4}$.

Nesse universo marcado pela extração do látex que jorrava da seringueira, a imposição da Bolívia e os protestos das autoridades brasileiras às novas medidas instituídas, não encontram ressonância junto ao governo da União e, após várias tentativas frustradas de obter apoio deste, inclusive enviando representante ao governo do Amazonas, Ramalho Júnior, "acharam prudente afastarem-se de Puerto Alonso".

A Bolívia se impõe, modifica a administração e os métodos de trabalho e organiza um sistema fiscal e policial caracterizado pela força.

A nova ordem, fundamentada nas leis bolivianas, que visavam assegurar e ampliar o domínio da Bolívia na região, recebeu a indiferença da população local, representada majoritariamente por brasileiros, considerando que os altos rios, como o Aquiri, nessa época, em 1899 "produzia mais de 60\% da borracha amazonense ou mais de 12 mil toneladas. Isso resultava de trabalho exaustivo dos brasileiros, lá estabelecidos, milhares deles

\footnotetext{
${ }^{4}$ CALIXTO, Valdir de Oliveira. Plácido de Castro e a construção da ordem no Aquiri: (Contribuição à história das idéias políticas). Rio Branco. Governo do Estado do Acre / Fundação Elias Mansour, p. 139.

${ }^{5}$ TOCANTINS, Leandro. Formação Histórica do Acre. 3. ed. Rio de Janeiro: Civilização Brasileira, 1978. p. 206.
} 
definitivamente localizados em vastas propriedades demarcadas e legalizadas pelo Estado do Amazonas",

É mister destacarmos que, segundo Craveiro Costa, havia nada menos que 40 mil extratores espalhados pela floresta, sem contar os trabalhadores das demais atividades ligadas ao seringal e à população que começava a se concentrar nos pequenos povoados em formação.

A população era na época de aproximadamente 70.000 pessoas, na quase totalidade brasileiros, devido "à conquista e à exploração das florestas ocorrer em sentido geográfico rigorosamente brasileiro""

Frente à ocupação brasileira em terras que lhe pertenciam por direito, a Bolívia reage e a questão aflorou quando se buscou dar efetividade ao tratado de 1867 por meio das comissões demarcadoras.

Em 1870, ocorreu a primeira dessas comissões, cujos trabalhos se alongaram até 1878. Porém, diante dos desentendimentos quanto aos pontos de limites estabelecidos no tratado e das reais situações confrontadas, os comissários brasileiros e bolivianos suspenderam os trabalhos, ficando acordado que os dois governos deveriam rever os limites inicialmente fixados.

Esses trabalhos iniciais alcançaram até as nascentes do rio Madeira e ficaram paralisados até 1895, quando se reconheceu a necessidade de completar-se a demarcação entre o Madeira e o Javari, sendo, então, nomeada uma Comissão Mista, que teve como representante brasileiro o general Thaumaturgo de Azevedo e o general José Manoel Pando por parte da Bolívia.

\footnotetext{
${ }^{6}$ COSTA, J. Craveiro. A conquista do deserto ocidental. São Paulo: Nacional, 1940, p. 29.

${ }^{7}$ TOCANTINS, Leandro. Op. Cit. p. 207.
} 
No entanto, o general Thaumaturgo de Azevedo fez questão de, ao iniciar os trabalhos, rever os limites anteriormente demarcados, inclusive as reais condições de produção da borracha e o povoamento da região por brasileiros desde a década de 1860 .

Rever o aludido tratado implicaria observar que a região demarcada como boliviana estava sendo ocupada por brasileiros. Diante desse fato, a revisão do tratado deveria assegurar aos brasileiros radicados na área os direitos sobre a região.

A proposta de Thaumaturgo, embora tenha sido bem recebida por segmentos da intelectualidade brasileira, com destaque para Rui Barbosa, da política nacional e de instituições relacionadas à questão em estudo, como o Instituto Politécnico Brasileiro, Sociedade Nacional de Geografia e Instituto Histórico Brasileiro, não obteve o reconhecimento que esperava do governo brasileiro, que, fazendo uma leitura da "questão do Acre" sob o prisma essencialmente jurídico, não acatou a sugestão dada. Diante do fato, Thaumaturgo demitiu-se da comissão.

Paralelamente a esses acontecimentos, a Bolívia buscou assegurar a sua soberania na região através de postos alfandegários. O governo brasileiro, na época representado pelo presidente Campo Sales, tendo como ministro das Relações Exteriores Dionísio Cerqueira, autorizou a instalação dos referidos postos. A ordem boliviana ia ser instituída na região.

Sendo o Aquiri ocupado por brasileiros, quantitativa e economicamente, os que desbravaram e ocuparam a região eram os que tinham direito ao território.

O clima de inquietude começava a ser delineado. Os "brasileiros do Aquiri", os patrões seringalistas, passam a resistir, à custa dos próprios esforços, à dominação boliviana.

E os altos rios, o Aquiri, tornaram-se um campo minado. A primeira atitude de revolta dos brasileiros, dos patrões-seringalistas, foi negar-se a pagar os pesados tributos impostos pela Bolívia e exigir a retirada da região do substituto de Paravacini, o ministro D. Moisés 
Santivanez, na perspectiva de que esse fato fizesse cessar as normas e decisões estabelecidas e aplicadas em nome da soberania boliviana.

Os protestos dos patrões-seringalistas para a retirada dos bolivianos obtiveram resultado momentâneo, e frente à gravidade da situação criada e à impotência da Bolívia de resolvê-lo, Santivanez retira a missão por ele instalada e chefiada, sem reação alguma, e retorna à Bolívia em busca de uma solução para o impasse.

Importante considerarmos que nesses fins do século XIX, em que o capitalismo assumia a feição monopolista e imperialista, o Brasil buscava instituir e consolidar uma nova ordem política - republicana e federativa -, calcada no ideário do positivismo e do capitalismo como modelo de desenvolvimento, de civilização. Defender a República implicava a aceitação do capitalismo como modo de vida.

E, nesse sentido, para o governo federal, o Aquiri precisava ser submetido à Ordem republicana; para os patrões-seringalistas, a Ordem é pensada e almejada através de diversos confrontos, armados ou não, entre brasileiros e bolivianos ou entre os próprios brasileiros.

Num circuito de Belém a Manaus, passando por Lábrea, Antimari até Caquetá, conspirava-se contra o domínio boliviano.

Em Caquetá, seringal de propriedade de Joaquim Victor, organizou-se uma Junta Revolucionária articulada a outros grupos de "revolucionários" de Belém e Manaus. Desse mesmo local, José Martins de Souza Brasil, juiz de Direito na Comarca de Floriano Peixoto, sob pressão dos revoltosos, notificou o delegado boliviano de que "estava no meio de um levante popular para depô-lo"8.

Eis o teor do documento.

Caquetá, 29 de abril de 1899.

A S. Exc ${ }^{\text {a }}$ o Sr. Delegado do Governo Boliviano em Pouerto Alonso. Tendo chegado ao meu conhecimento que se preparava um grande movimento popular contra a autoridade que V. Exc ${ }^{\mathrm{a}}$. está exercendo no território da Comarca de Antimary, para aqui dirigi-me a fim de no caráter de autoridade

\footnotetext{
${ }^{8}$ Relatório Paravicini. Apud TOCANTINS, Leandro. Op. Cit. 216- 217.
} 
estadual obstar que esse movimento se efetuasse. Entretanto, porém, em comunicação com os principais promotores do levante, cheguei à evidência de que todos os esforços que empregue serão inúteis em vista da força de que estes dispõem; acrescendo ainda que não tenho instrução do governo brasileiro para manter V. Exc $c^{a}$. no posto em que se acha, a meu ver irregularmente, nem de V. Exc ${ }^{a}$. comunicação quanto ao acordo celebrado com o nosso governo.

Violento ou arbitrário o povo dispõe de elementos materiais que a autoridade pública não pode sobrelevar, tanto mais faltando-lhe o apoio oficial dos superiores da nação.

Em tais condições, observando o estado de exaltação patriótica em que se acham os espíritos, cumpre-me apenas, como intermediário prudente entre V. Exc ${ }^{\text {a }}$ e o povo brasileiro a cuja causa me prendem, como cidadão, tantos vínculos de solidariedade e simpatias, cumpre-me apenas, digo, pedir a V. $E{ }^{a}$., se digne proceder de modo a poupar sacrifícios inúteis e talvez desastres irreparáveis.

É o que espero da experimentada prudência de V. Exc ${ }^{\mathrm{a}}$. a quem tenho a distinta honra de apresentar vivos protestos de alta consideração. Saúde e Fraternidade. José Martins de Souza Brazil, Juiz de Direito, interino da Comarca ${ }^{9}$.

Em resposta, Santivanez responde ao juiz de Direito que

Señor en este momento he recebido su attenta comunicación de la fecha y quedá verdadeiramente surpreendido con su texto. No alcanzo a comprender los propósitos de un movimento popular contra la tranquilla posesion de esta fronteira, oficialmente reconocida por la Respectable Chancillería brazileira, ocupada el dia 2 de Enero ultimo en virtud de acuerdos prévios, transmitidos a la primieira autoridad del Estado de Amazonas, como consta por publicaciones de la prensa manauense. Qualquer alteración en este ordem de casos, y en ese sentido descaso en la regularidad de los procedimientos de esta Delegación durante la gestion de mi digno jefe el Snr. José Paravicini, y en el prestigio del Gobierno del Brazil, que no consentiria jamas abuso alguno.

Por lo demas, me permitirá V. rogarle ser mais explícito encuanto a los alcanses del texto de sua aludida comunicación. No creo haber dado motivo en el curto espacio de sete dias de mi interionato á sacrifícios inútiles y aun desastre que fuera necesario evitar con experiente prudencia; francamente, no se que se pretende, y en todo caso, espero de su gentileza uma explicación a este respecto, seguro de que $\mathrm{V}$. encontrará todo el esfuerzo en pró de la armonia y buena relacion internacional, en su atento y obsecunte. S. S. M. Santinez - Delegado interino Del Acre y Purús ${ }^{10}$.

\footnotetext{
${ }^{9}$ CALIXTO, Valdir de Oliveira. Op. Cit. p. 143.
}

${ }^{10}$ CALIXTO, Valdir de Oliveira. Op. Cit. p. 144. 
Os discursos de ambos os documentos apresentam dizeres diferenciados sobre os acontecimentos, a partir do lugar social de onde provêm os seus autores e dos interesses que representam.

Para o juiz, há um movimento popular contra o domínio boliviano, enquanto o diplomata boliviano entende que o movimento é contra a autoridade estabelecida.

Como parte desse processo, em $1^{\circ}$ de maio de 1899, Santivanez recebeu uma intimação assinada por mais de cinqüenta seringalistas, um bacharel em Direito e um engenheiro civil, em nome da "vontade soberana" do povo de Antimari.

O povo brasileiro representado por nós abaixo assinados solidariamente responsáveis, no uso de sua alta vontade revoltada, vem intimar-vos para que abandoneis o governo ilegal que vos achais exercendo atualmente neste território desbravado, habitado e hoje defendido, por milhares de brazileiros, que até a vossa invasão aparentemente legal, viviam a sombra das leis de seus pais, e nelas confiavam ${ }^{11}$.

Da análise do documento acima, podemos inferir que o conceito de território, de região, é algo inventado, construído a partir das relações econômicas, políticas, jurídicas e culturais que se estabelecem entre os que ocupam um determinado espaço geográfico. Mais do que diante de uma questão geográfica, estamos diante de uma questão de poder.

E o Estado brasileiro, a República brasileira, é o campo de luta dessa disputa de poder. A fronteira entre Brasil e Bolívia, mais do que física, é política, econômica e social.

O sentido de territorialidade é imaginado, a partir do uti possidetis (a terra pertence a quem a ocupa). O social e o econômico sobrepõem-se ao político-jurídico-institucional. O território foi desbravado e habitado por brasileiros. Portanto, a ocupação boliviana era ilegal. “Estais intimado a vos retirar. Deixai o vosso governo este território o mais breve possível,

${ }^{11}$ CARVALHO, José de. A primeira insurreição acreana (documentada). Pará: Gilelet, 1904, p. 15. 
porque é esta a vontade soberana e geral do povo deste Município e de todo o povo brazileiro" $" 12$.

E a influência dos postulados filosóficos do liberalismo estão presentes no imaginário dos que se rebelaram contra a Ordem boliviana.

Em nome do povo, fonte da legitimidade e representatividade do poder, da propriedade e da Constituição brasileira, a delegação boliviana foi deposta em Puerto Acre.

No entanto, como se explica que o principal líder do movimento, José de Carvalho, tenha sido processado como "lesa-pátria", sendo proibido pelo governador Ramalho Jr. de retornar a Manaus?

Por que esse tratamento ao líder dos revoltosos, se eles agiram em nome da Pátria, da construção da Ordem republicana e da soberania brasileira?

A esse respeito é importante considerarmos que a chamada "República Velha" foi instaurada a partir de uma política de compromisso que concedeu ao consórcio das oligarquias paulista e mineira a hegemonia política nacional, e as oligarquias regionais gravitavam em torno destas e, como um pêndulo, dependendo do jogo das forças políticas, ora apoiavam os paulistas, ora os mineiros e as benesses que os seus locais de origem recebiam do governo federal, bem como a capacidade de intervenção dessas na política nacional dependia do "poder de fogo" que possuíam.

Considerando o cenário brasileiro, percebemos que José de Carvalho e seu grupo de apoio político não constituíam o núcleo forte da oligarquia dos Ramalhos. Aliás, o próprio líder do primeiro e expressivo movimento contra a ocupação boliviana no Aquiri revelou em 1904 críticas aos procedimentos da classe dominante amazonense.

$\mathrm{Na}$ condição de "não-confiável” ao governo do Amazonas, José de Carvalho não recebeu nenhum apoio para as suas ações no Aquiri. A deposição da delegação boliviana

${ }^{12}$ CARVAlHO, José de. Op. Cit. p. 28. 
ocorreu em nome da Pátria, da soberania nacional, do povo, e não em nome do governo do Amazonas. Os valores filosóficos, políticos e éticos sobrepuseram-se aos interesses regionais. É mister destacar que os primeiros anos da República brasileira foram marcados pelos conflitos entre o poder nacional e as tentativas de afirmação das oligarquias regionais no contexto brasileiro.

Sem apoio, doente e indesejável aos interesses do Amazonas, José de Carvalho afastou-se de Manaus e do campo movediço do Aquiri.

O rumo dos acontecimentos no Aquiri passará a ter outra liderança - D. Luís Galvez Rodrigues de Aria.

Quem foi Galvez? De que lugar social nos fala?

Luiz Galvez Rodrigues de Aria era espanhol, ex-diplomata, jurista e jornalista que participara de movimentos sediciosos em áreas da América Latina e que, chegando em Manaus, entrou em contato com Ramalho Júnior (governador do Amazonas). Através da imprensa, escreveu vários artigos acerca da luta que estava sendo travada no Aquiri para a sua anexação ao território brasileiro.

Galvez irrompeu no cenário dos altos rios num contexto em que nacionalmente a Ordem monárquica estava no "apagar das luzes", na medida que o movimento republicano ganhava força conseguindo defensores, inclusive entre os setores conservadores.

A esse respeito, importante considerarmos que o advento da República brasileira ocorreu numa correlação de forças políticas em que os liberais, especialmente os exaltados, as camadas médias da sociedade nacional, notadamente as mais esclarecidas, do ponto de vista da cultura erudita, e os militares, particularmente o Exército brasileiro, reivindicavam mudanças econômicas e políticas coerentes com o liberalismo e o nacionalismo.

E o Brasil, até então, era um país essencialmente produtor e exportador de bens primários, apresentando como características a grande propriedade, a escravidão e a 
especialização da produção nacional voltada, preferencialmente, para o mercado externo, tendo como maior expressão política os cafeicultores e figurando no contexto internacional como economia dependente.

Em fins do século XIX e início do XX, na chamada era do capital monopolista e imperialista, a conjuntura brasileira é marcada pela implementação do projeto de modernização, de progresso, numa ótica liberal-conservadora, tendo em vista os limites que o liberalismo teve no Brasil.

Os aspectos mais destacados do liberalismo pelas forças que almejavam o progresso eram o econômico e o político. No campo social a visão dominante era manter o status quo.

Modernizar o Brasil significava abolir a escravidão, desenvolver a industrialização, urbanizar as cidades brasileiras, sobretudo as capitais, segundo os postulados urbanísticos da belle époque e promover mudanças no campo das comunicações.

O progresso numa perspectiva capitalista centrado numa ordem política e social conservadora e preservadora dos privilégios dos setores sociais dominantes - eis o ideário da República no Brasil.

No entanto, a instauração da Ordem republicana brasileira não ocorreu de forma pacífica, linear, harmônica, como a historiografia de cunho positivista retrata, mas pontilhada de conflitos internos, de contradições.

Os republicanos vencedores tiveram que lutar contra os que tentavam subverter a ordem - os monarquistas, os restauradores, que se dividam em duas alas. Uns achavam que a situação era reversível, outros transformavam-se em neo-republicanos.

Foi nessa conjuntura de ebulição política e anseios de mudanças econômicas e sociais em nível nacional que Galvez ingressou no "campo de guerra" do Aquiri, no momento em que os patrões seringalistas, em estado de beligerância, necessitavam encontrar um 
personagem que aglutinasse as forças políticas locais para uma definição da libertação do Aquiri do domínio boliviano.

E a escolha recaiu sob Galvez, por já estar envolvido com a "questão do Acre" inclusive estava ligado à Junta Revolucionária do Acre, organizada desde 24 de fevereiro de 1899, e da qual era representante nos Estados do Pará e Amazonas.

De Belém, onde adquiriu grande fama como jornalista, notadamente da causa acreana, Galvez transferiu-se para Manaus, tendo recebido apoio do governador Ramalho Júnior para a concretização de sua meta - lutar contra os bolivianos.

De Manaus viajou para o seringal São Jerônimo, onde, juntamente com os componentes da Junta Revolucionária do Acre, marcou a data de 14 de julho para proclamar o Estado independente do Acre.

Por que 14 de julho?

Trata-se de uma data imbuída de significado libertário, na medida que se tornou marco da luta do povo francês contra a intolerância, o arbítrio e o absolutismo monárquico, simbolizados na tomada da Bastilha.

Por outro lado merece destaque o fato de que as duas primeiras décadas do século XX no Brasil foram marcadas pelas manifestações do discurso e da prática do Jacobinismo a la brasileira que incorporou vários signos de sua matriz histórica - A Revolução Francesa.

Os jacobinistas brasileiros, em geral, foram grupos de civis e militares, representantes dos setores médios da sociedade e do Exército, dentre outros que se notabilizaram como republicanos e nacionalistas.

Esses "radicais da República", segundo Suely Robles, eram defensores da implantação de um Estado republicano, nacionalista e voltado para as suas fronteiras. Exaltados, através da imprensa, comícios, passeatas dos batalhões patrióticos, reuniões políticas nos clubes formados e levantes nas escolas militares marcaram o processo de consolidação da República. 
De inspiração Castrense, tinham uma mentalidade salvacionista, de forte influência positivista, fundamentada na doutrina do soldado-cidadão.

Xenófobos combatiam o estrangeirismo, que era identificado com os monarquistas, sendo estes responsabilizados pelos males que padeciam a nação brasileira.

Florianistas ferozes, os jacobinos hostilizaram Prudente de Moraes e o confronto polarizou-se, tendo-se de um lado o poder civil, que buscava afirmar-se e do outro, as ambições militares de poder.

Merece destaque assinalarmos, conforme as reflexões de Michel Vovelle que no seu processo de transmutação pelo mundo, o jacobinismo, embora vinculado historicamente a matriz francesa, adquiriu características peculiares em cada região.

E Galvez como se situava frente ao Jacobinismo?

Embora fosse portador de uma ideologia liberal humanitária que unia nacionalismo, liberdade e ordem, fez uso do simbolismo das palavras de ordem dos jacobinos. Pátria, soberania, liberdade, salvação, povo, nação, armas. . ., como demonstra o texto da proclamação do Estado Independente do Acre.

Cidadãos todos conheceis os motivos que nos obrigaram a organizar a Junta Revolucionária do Acre. Altivos e nobres cidadãos brasileiros, respeitadores, sempre as leis e dos governos encarregados de interpretá-los, obedecemos cegamente a invasão destes territórios por uma titulada Delegação Nacional da Bolívia, que, desde o dia da sua chegada, constituiuse em governos, decretando leis draconianas, criando impostos absurdos e proibitivos e para completar tamanha audácia nos declararam cidadãos bolivianos sem prévia consulta de nossa vontade. ${ }^{13}$ [grifos nossos].

O caráter panfletário, embora não incendiário, dos manifestos lançados pelos clubes jacobinos franceses está presente no texto acima, que se encontra eivado de expressões alusivas a cidadania, ordem, lei e nobreza de caráter.

\footnotetext{
${ }^{13}$ Ata da $22^{a}$ sessão da Junta Revolucionária do Acre. IAHP.
} 
Liberalismo, nacionalismo, independência e Ordem mesclam-se dialeticamente na fala metafórica de Galvez.

No universo de Galvez, os inimigos eram vistos como bárbaros, pois decretavam leis draconianas, criavam impostos absurdos e proibitivos e os declaravam cidadãos bolivianos, sem consultá-los.

Dando continuidade ao seu discurso, sempre falando no plural, já que representava, naquele momento, a Junta Revolucionária, Galvez, no supramencionado documento, assevera: "Aceitamos as leis, pagamos tributos e impostos e obedecemos passivamente, todos os julgamentos de alta e baixa justiça praticados pelo Delegado Nacional da Bolívia, na esperança que nossa idolatrada pátria e gloriosa e humanitária Nação brasileira acudisse em nosso socorro e atendesse nossos justíssimos pedidos" $" 14$.

As expressões tais como Humanitária Nação, Pátria e Liberdade, Liberdade e Justiça, Sentimentos Humanitários são termos recorrentes no ideário da Junta Revolucionária e nos remetem a outros conceitos como o de Ordem ou de Estado, os quais se inserem nas matrizes do liberalismo e do nacionalismo.

Por outro lado, percebemos que para Galvez a ação política deveria estar subordinada ao ético, ao moral numa clara alusão ao pensamento de Rosseau e Kant.

E nos faz "ouvir" os ecos dos jacobinos aguerridos, absolutistas do povo, que durante o terror "cortavam as cabeças" dos "inimigos do povo", dos "traidores da pátria", "traidores do povo".

Nos remetendo, ainda para o pensamento de Rousseau ao defender a idéia de que “nenhum povo jamais poderia ser senão aquilo que a natureza do seu governo fazia dele." 15 .

\footnotetext{
${ }^{14}$ Ata da $22^{a}$ sessão da Junta Revolucionária do Acre. IAHP.

${ }^{15}$ OLIVEIRA, Lúcia Lippi. A Questão Nacional na Primeira República. São Paulo: Brasiliense. 1990. p. 3147.
} 
Aos cidadãos de "patriótica virtude", bondade e verdadeiros sentimentos de liberdade estava designada a honrosa tarefa de construir a independência do Acre.

E, nesse sentido, o verdadeiro cidadão era aquele que se subordinava a lei, a vontade geral do Estado, na medida que reconheciam as decisões do governo como suas.

Liberdade, poder e ordem formavam um todo indivisível. Liberdade sim, mas com Ordem, ou seja obediente a República brasileira.

Mais adiante, assinalou:

O governo do Brasil não respondeu aos nossos patrióticos alarmes: a Pátria a nossa estremecida mãe, personificada em grupos de valentes e caritativos irmãos, respondeu sem precisar de nosso apelo; no dia $1^{\circ}$ de maio data que conservaremos gravada em nossos corações, ilustres e denodados irmãos que surpreenderam com a patriótica intimação que dirigiram em nome do povo brasileiro às autoridades bolivianas que por falta de força e prestígio nos abandonaram com a mesma facilidade que nos conquistaram: dois meses e meio são transcorridos e nada, absolutamente sabemos em que ficamos depois do abandono em que nos deixaram as autoridades brasileiras e bolivianas; unicamente um fato veio agravar mais nossa inexplicável situação: o processo judicial levantado contra aqueles destemidos $e$ humanitários irmãos pelo crime de querermos livrar da escravidão a que nos submeteram as autoridades bolivianas; o silêncio do governo do Brasil e esse nefasto processo nos demonstra que os habitantes destas regiões não pertencem à livre e grande Pátria brasileira ${ }^{16}$. [grifos nossos]

Fica patente a desilusão de Galvez com o que esperava receber de apoio da pátriamãe, do governo brasileiro.

Torna-se evidente não só o lamento de Galvez diante da indiferença do governo do Brasil no que se referia à luta dos brasileiros para expulsar os bolivianos do Acre, quanto à crítica ao governo do Amazonas por ter processado José de Carvalho, humanitário irmão, que lutou contra a dominação boliviana e, ainda a reprovação ao "silêncio" do Brasil - a livre e grande pátria brasileira acerca do que estava acontecendo no Acre.

${ }^{16}$ Ata da $22^{\text {a }}$ Sessão da Junta Revolucionária do Acre. IAHP. 
Sentindo-se desprezado e discriminado pela Ordem, à qual queria pertencer, não restava à Junta Revolucionária do Acre, através do seu representante, outra alternativa senão criar o Estado Independente do Acre.

Desta maneira, Galvez concluiu seu discurso de forma enfática afirmando que era:

Justo pois que os cidadãos livres, conhecedores de seus direitos civis e políticos, não se conformem com o estigma de párias criado pelo governo de sua Pátria, nem podem, de forma alguma, continuar sendo escravos de uma outra nação - a Bolívia. Impõe-se a independência destes territórios que elegeram seu governo entre aos cidadãos que trabalham seu solo $e$ exploram as suas riquezas; é pois, chegado o momento de proclamar nossos indiscutiveis direitos de cidadãos livres; é necessário levantar nossa honra pela Bolivia depreciada; cidadãos: escutai a proclama que o povo dos Territórios do Acre, Purus e Iaco dirige a Junta Revolucionária, manifestar vossa livre opinião que sempre respeitamos; se não aceitais a independência, continuaremos a sofrer humilhações que nos impõem uma nação estrangeira: se, pelo contrário, aceitares independência, continuaremos o Estado Independente do Acre, valoroso, forte e digno pelo patriotismo de seus filhos; poderoso pelas suas inesgotáveis riquezas que ousados estrangeiros nos querem usurpar ${ }^{17}$. [grifos nossos].

Com este ato foi criada uma República no Acre, meses antes da proclamação da República (15 de novembro de 1889), sob a denominação de Estado Independente.

No mesmo dia - 14 de julho - foi organizado o governo provisório, sendo Galvez escolhido para ocupar o cargo de Presidente, com “plenos e ilimitados poderes".

Após a sua aclamação, Galvez declarou terminada a reunião, o que fez entre o maior entusiasmo e ordem do povo. Foram dadas as "vivas" ao Estado Independente do Acre.

A Ata desta reunião foi assinada por Joaquim Domingos Carneiro, Presidente da Junta Revolucionária do Acre e o futuro Coronel da Guarda Nacional e mais 41 Delegados presentes.

Com a criação da República, Puerto Alonso passou a denominar-se "Cidade do Acre”, sendo instalado o governo provisório. A Ordem foi instalada nos altos rios da Amazônia Sul

\footnotetext{
${ }^{17}$ Ata da $22^{a}$ Sessão da Junta Revolucionária do Acre. IAHP.
} 
Ocidental e, a partir desse ato, foram criados os mecanismos de instituição da mesma (Polícia, Tribunal de Vigilância e Punição a todos os tipos de infração, particularmente os crimes considerados sediciosos e os relacionados à violação da propriedade).

Proclamando que aceitou o cargo para o qual o povo o aclamara e comprometendo-se a formar o governo provisório, que teria por fundamento - liberdade e justiça, Galvez anuncia a organização da recém-criada República.

A composição do governo de Galvez era a seguinte:

Secretários de Estado, os cidadãos Joaquim Domingos Carneiro e Ezequiel A. de Araújo, sendo as demais pastas, assim ocupadas: Coronel Hipólito Moreira (Ministro de Justiça), Dr. Albino dos Santos Pereira (Ministro do Exterior), Joaquim Domingos Carneiro (Ministro da Fazenda), Coronel José Galdino de Assis Marinho (Ministro da Guerra), João Passos d' Oliveira (Chefe de Polícia), professor Ezequiel Alves de Araújo Prima (Secretário Geral $)^{18}$.

Era, por sua vez, também necessário estabelecer os limites do Estado Independente do Acre, o qual ficou circunscrito

[. . . ] ao norte, a linha geodésica que saindo das nascentes do Javari, isto é, latitude $7^{\circ} 11^{\prime} 48^{\prime \prime}$ e longitude $73^{\circ} 47^{\prime} 44^{\prime \prime}$ oeste de Greenwich, chega até a Vila Bela, ou seja até o ponto cujas coordenadas geográficas são: latitude $10^{\circ} 20^{\prime}$ e longitude 65 $24^{\circ}$ '59" oeste de Greenwich. Ao sul, rio Madre de Dios. Ao sul-oeste, limite atual entre as repúblicas da Bolívia e do Peru ${ }^{19}$.

No Decreto de n. 2, Galvez criou o símbolo do estado - a bandeira que deveria conter: “dois triângulos retângulos ligados pela hipotenusa, o superior de cor verde e o inferior de cor amarela, tendo no vértice superior uma estrela vermelha solitária"20.

\footnotetext{
${ }^{18}$ CALIXTO, Valdir de Oliveira. Aquiri (1898 - 1909). Os patrões e a construção da ordem. São Paulo: USP, 1993, p. 239.

${ }^{19}$ Decreto número 1, de 15 de julho de 1899. In: CALIXTO, Valdir de Oliveira. Aquiri (1898 - 1909). Os patrões e a construção da ordem. p. $239-241$.

${ }^{20}$ Decreto de número 2, de 15 de Julho de 1899. In: CALIXTO, Valdir de Oliveira. Aquiri (1898-1909). Os patrões e a construção da ordem. p. 241. A atual bandeira do Acre preservou o desenho de 1899, porém inverteu as cores: verde na parte inferior e amarelo na parte superior.
} 
Importante destacarmos que o simbolismo de cores da bandeira: a estrela rubra - a liberdade com o barrete frígio. O 14 de julho. A bandeira nacional, a oleografia de Campos Sales nos “escritórios da Presidência - revela um dos aspectos do eclético universo mental de Galvez"21.

Ao criar os símbolos do Estado recém-instituído, no seu "Palácio", descrito por ele de forma singela "uma reduzida barraca, muito inferior a qualquer outra que se via às margens do Acre", tendo numa das paredes do "salão",22

Escudo de armas de la revolución com la seguinte inscripción a su centro: "Pátria e Liberdade" y temiendo la bandera brasileña su cortaz izquerdo, mientras que em direcho se veia la de revolución com los mismos colores que la anterior, - amarilla y verde -, separadas diagonalmente, y luciendo uma estrella roja próxima a asta de la bandera. Coronaban el escudo, la testa de la liberdad com el gorro frígio, algumas laureles y la fecha da la revolución separatista. 14 de julho de $1899^{23}$.

É evidente que o tom do discurso de Galvez nos remete a outros discursos, de feição jacobinista, que estavam ocorrendo na capital brasileira - Rio de Janeiro - e que se intensificaram na primeira década do século XX.

Neste período, “os radicais da República", leia-se - jacobinistas e florianistas ferrenhos, em confronto com os "subversivos da República" - monarquistas, usavam um discurso e uma práxis mais contundente. No entanto, do ponto de vista das idéias, podemos afirmar que Galvez foi um jacobinista adaptado a realidade da Amazônia de fins do século XIX e início do XX, que utilizou uma prática política condizente com a fragilidade da tentativa de afirmação do poder local em confronto com o poder central.

\footnotetext{
${ }^{21}$ ACHA, José Aguirre. De los Andes al Amazonas. La Paz. 1980. p. 269. In: CALIXTO. Valdir de Oliveira. Aquiri (1898 1909). Os patrões e a Construção da Ordem. p. 241.

${ }^{22}$ Ibid. p. 241.

${ }^{23}$ Ibid. p. 241.
} 
É possível que a linguagem e a postura de Galvez se apresentasse "adocicada", "humanitária", demais para os jacobinos brasileiros, na medida que, em outras regiões, o jacobinismo a la Brasil teve um caráter militarista acentuado.

É fundamental destacarmos que Galvez estabeleceu medidas de certo impacto social e econômico, como a criação de centros agrícolas e pastoris para atender a demanda interna, a convocação de uma constituinte, para que o povo, por meio de seus representantes pudesse opinar nas questões do governo e a outorga de uma constituição que deveria ser apreciada pelo "Congresso Constituinte".

Tais medidas eram contrárias aos interesses econômicos e políticos dos patrões seringalistas que "fizeram" o Estado Independente do Acre.

Esta última medida citada previa, inclusive, a realização de eleições no dia 15 de janeiro de 1900, para eleger, através do Congresso, o Presidente e o Vice-Presidente da República criada no dia 14 de julho.

No entanto, é notório afirmarmos que a República de Galvez, apresentou contradições internas que emergiram em focos sediciosos que minaram e desacreditaram o regime, os quais ocorreram em pontos os mais diversos - Xapuri (Alto Acre), que por meio de ofício manifestou não aderir a Revolução, sem primeiro ouvir a decisão do governo brasileiro acerca da questão do Acre; outro, denominado "Comissão Garantidora dos Direitos", que também buscava desestabilizar o governo provisório; e no Baixo Acre, havia uma propaganda antigoverno liderada por Neutel Maia, do "seringal Empresa ${ }^{24}$ e o Capitão Leite Barbosa, do seringal Humaitá ${ }^{25} "$

\footnotetext{
${ }^{24}$ O Seringal Empresa foi fundado por Neutel Newton Maia, em 1882, e deu origem, com o seu desdobramento, a cidade de Rio Branco, capital do estado do Acre na atualidade. Neutel Maia tornou-se, posteriormente, membro da Guarda Nacional e foi um dos ferrenhos opositor de Galvez.

${ }^{25}$ CALIXTO, Valdir de Oliveira. Aquiri (1898-1909). Os patrões e a construção da ordem. São Paulo: USP, 1993. p. 245.
} 
A estratégia de Galvez para superar os focos de resistência foi, num primeiro momento, o diálogo; quando este não trazia os resultados esperados, fazia uso da ação enérgica.

Porém, é mister assinalarmos que, se de um lado Galvez não estava sozinho - possuía uma base de apoio junto aos patrões seringalistas da região -, do outro, as medidas econômicas $^{26}$ instituídas por este, ao contrariarem os interesses ligados à borracha, mais especificamente à exportação deste produto, contribuíram para acentuar, gradativamente, as pressões contra ele, através de sedições como a organizada por Antônio Souza Braga, comerciante de Belém que, juntando-se a outros sediciosos, resolve depor Galvez e proclamar-se Presidente do Estado Livre do Acre.

Este, através do decreto n. 1 - primeiro ato administrativo do novo governo, resolveu banir Luiz Galvez do Estado Livre do Acre e, no de n. 4, decretou o livre trânsito de vapores, neste Estado, pelo antigo regime constitucional, sendo, portanto, livre o embarque de todos os gêneros de comércio ${ }^{27}$.

Galvez, frente ao despreparo de Antônio Braga para o exercício do cargo de Presidente, retornou ao poder algumas vezes, porém, a experiência da República implantada por este estava agonizando, pois os representantes das grandes casas aviadoras - o governo estadual do Amazonas e o próprio governo federal - uniram-se contra as decisões tomadas pelo governo Provisório da República Liberal de Galvez ${ }^{28}$.

Em Manaus, as críticas ao governador Ramalho Júnior cresciam devido ao seu envolvimento, com o que denominavam - a questão do Acre, interferindo, inclusive, na sucessão estadual.

\footnotetext{
${ }^{26}$ Galvez, dentre as medidas de caráter econômico criadas estabeleceu que, de toda a produção da borracha produzida no Acre deveria ser pago, pelas casas Aviadoras e Exportadoras de Belém e Manaus, o imposto de 10\%.

${ }^{27}$ Anarquia do cidadão Antônio Souza Braga. 28 de Dezembro de 1899. 28 de Janeiro de 1900. IAHP. In: CALIXTO, Valdir de Oliveira. Aquiri (1898 - 1900). Os patrões e a construção da ordem. São Paulo: USP, 1993. p. 255.

${ }^{28}$ Ibid. p. 255.
} 
Por sua vez, os bolivianos, em Belém, com apoio do governo federal, utilizavam a imprensa para produzir e disseminar um imaginário desprestigioso para Galvez - "de opositor ao imperialismo, este passou a ser visto como aventureiro audacioso, estrangeiro intrometido e extorsionário das rendas fiscais do Amazonas

O próprio Ramalho Júnior, que antes elogiava Galvez - tinha-se aliado a este, a partir de então - , passou a acusá-lo de separatista.

Finalmente, em 1900, Galvez, frente à oposição que sofria, rendeu-se sem resistência ao comandante da flotilha federal, sendo levado para Manaus, de onde foi expulso, embarcando numa longa viagem de exílio para a Europa.

Após o episódio da fracassada experiência da "República de Galvez", por mais de três vezes a Ordem foi proclamada nos altos rios. No entanto, o desfecho da questão do Acre teve, na sua fase decisiva, a ação histórica de outro personagem - José Plácido de Castro, o comandante-em-chefe da "Revolução Acreana".

Plácido de Castro, gaúcho de São Gabriel do Batovi, era proveniente de tradicional família militar, tendo, inclusive, seu avô paterno, de quem herdou o nome, participado ativamente das guerras platinas no período de 1811 e 1828.

Ingressou nas fileiras do Exército aos 16 anos, tornando-se $2^{\circ}$ cadete em 30 de julho de 1890 e finalmente aos 20 anos conseguiu matricular-se na Escola Militar de Porto Alegre.

Nessa época, o Rio Grande do Sul encontrava-se mergulhado nos conflitos políticos representados pelas divergências entre os republicanos históricos, como Júlio de Castilhos, republicanos dissidentes, como Assis Brasil, e por liberais e republicanos históricos, como o Visconde de Pelotas e Silveira Martins.

Merece assinalarmos que a conjuntura política do Rio Grande do Sul, em fins do século XIX, estava caracterizada pela instabilidade política, pois com a deposição de Júlio de

\footnotetext{
${ }^{29}$ TOCANTINS, Leandro. Formação Histórica do Acre. Rio de Janeiro: Civilização Brasileira. 1979. v. 1. p. 315.
} 
Castilhos, eleito anteriormente, por não ter apoiado o golpe de Deodoro da Fonseca ao dissolver o Congresso, este reassumiu transitoriamente e finalmente afastou-se do poder, sendo o governo gaúcho representando por um triunvirato, denominado "governicho" integrado pelos republicanos castilhistas.

Neste contexto político e ideológico das lutas para consolidação da República brasileira, os alunos da Escola Militar foram solicitados a se manifestar acerca do fechamento da mesma, para que estes e seus professores pudessem exercer na prática o ardor patriótico republicano, como "Plácido de Castro silenciou a sua posição passou a ser visto com suspeição e como punição foi recolhido preso ao $13^{\circ}$ Batalhão de Infantaria e em seguida recambiado para Campanha com classificação no Corpo de Transporte aquartelado em Bagé ${ }^{\prime 30}$.

Este fato viabilizou em seguida o envolvimento deste no acampamento maragato e sua participação no combate do Rio Negro.

Integrando as forças oposicionistas a República ao término da "cruenta guerra civil”,31, o governo do Presidente Prudente de Morais anistiou os que se envolveram nesta. No entanto, Plácido recusou ser anistiado e reintegrado ao Exército. A partir de então, após breve estada com os familiares em São Gabriel, partiu para o Rio de Janeiro e São Paulo, e em princípios de 1899 chegou à Amazônia.

Chegando ao Rio de Janeiro e procurando o Colégio Militar foi durante breve período estigmatizado como maragato e monarquista.

$\mathrm{Na}$ condição de "persona non grata" envolveu-se em conflitos com os florianistas saudosistas vindo a ser exonerado do Colégio Militar.

\footnotetext{
${ }^{30}$ CALIXTO, Valdir de Oliveira. Plácido de Castro e a construção da ordem no Aquiri (contribuição à história das idéias políticas). Rio Branco: Governo do Estado do Acre / Fundação Elias Mansour, 2003. p. 186.

${ }^{31}$ FLORES, Hilda Agnes Hübner e FLORES, Moacir. Rio Grande do Sul: Martins Livreiro, 1999, p. 115 In: CALIXTO, Valdir de Oliveira. Plácido de Castro e a construção da ordem no Aquiri (Contribuição à história das idéias políticas), p. 195.
} 
Do Rio de Janeiro foi para São Paulo, onde após curta permanência trabalhando na Companhia Doccas dos Santos rumou para a Amazônia em decorrência do seu trabalho como agrimensor.

Como ocorreu a vinda de Plácido de Castro para o território convulsionado dos altos rios, do Aquiri?

Ao tomar conhecimento que um ex-oficial do Exército Federalista encontrava-se em Manaus, dirigiram-se para aquela cidade Rodrigo de Carvalho, Joaquim Victor e Gentil Norberto com o objetivo de convidá-lo para chefiar o movimento de resistência à ocupação boliviana.

Informado sobre a "questão do Acre", tendo inclusive um juízo formado sobre a mesma, Plácido de Castro aceitou o desafio de assumir o comando da luta para expulsão da Bolívia do Aquiri. Importante assinalarmos que o mesmo já havia sido contactado para participar da Expedição Floriano Peixoto que, posteriormente, fora denominada por este de Expedição dos Poetas.

Em carta datada de 10 de julho de 1902, proveniente do Seringal Bom Destino, ao Silvério Nery, Rodrigo de Carvalho diz:

Reunida a Junta Revolucionária e vários cidadãos acreanos de reaes merecimentos, em 1 do corrente, ficou por ella deliberado, com unânime aprovação de todos, o seguinte: Nomear o nosso concidadão José Plácido de Castro para dirigir as operações militares, como Comandante em chefe das Forças, para o qual concorremos, com todo o nosso apoio moral e intellectual. O acclamado escolherá quatro Secretários para as pastas da Guerra, Industria, Justiça e Relações Exteriores, e Fazenda. Notificará a formação do governo as nações americanas e pedirá ao Governo Brasileiro annexação à Pátria brasileira. Pela distincção que mereceu da Junta Revolucionária o Sr. Plácido, podeis ver que elle é da mais absoluta confiança e, além de muita vida e mocidade, ainda possue a decisão que requer o cargo que vai acupar ${ }^{32}$. [Grifos nossos]

\footnotetext{
${ }^{32}$ Acta da Sessão Extraordinária da Independência do Acre a 7 de agosto de 1902. Apude OURIQUE, Jacques, op. Cit. p. 230.
} 
Do aludido documento destacam-se vários aspectos importantes. Em primeiro lugar, fica evidente que os "cidadãos acreanos de reais merecimentos", eram os grandes proprietários de seringais. Em segundo lugar, fica caracterizado o envolvimento da oligarquia amazonense com os conflitos do Aquiri, através de Rodrigo de Carvalho. Em terceiro lugar, que havia consenso entre os membros da Junta quanto a entrega do comando das operações militares contra os bolivianos a Plácido de Castro devido ao preparo deste adquirido durante a Campanha Sul-Rio grandense. Em quarto lugar, que antes mesmo da definição do desfecho da luta a ser empreendida, a vitória sobre os bolivianos era considerada como algo inevitável, configurando-se a estrutura do futuro Estado foram criadas as secretarias da Guerra, da Indústria e da Justiça, das Relações Exteriores e da Fazenda. Em quinto lugar, que o novo Estado a ser criado seria integrado a "Pátria brasileira".

Ficam caracterizados, portanto, a fidelidade à mãe pátria brasileira e o caráter não separatista dos "cidadãos de reais merecimento".

Posteriormente, em 7 de agosto de 1902, reunidos em Xapuri, na "Casa dos Srs Falck \& Vieira" ${ }^{33}$, reproclamava-se a independência do Acre, embora de fato ela já tivesse sido reproclamada no dia seguinte à deposição de D. Juan de Dios Barretos, Intendente de Xapuri, em 6 de agosto, data em que se comemora a independência da Bolívia.

Da reproclamação até a tomada de Puerto Acre, sede da Delegacia Nacional, em 24 de janeiro de 1903, sucederam-se os combates, em que tanto os brasileiros quanto os bolivianos deram demonstração de destemor, de heroísmo. E paralelamente aos combates militares, ocorria a intensa troca de correspondência entre D. Lino Romero e o Comandante-em-Chefe das Forças Revolucionárias, Plácido de Castro.

E, à medida que o desfecho final da luta entre brasileiros e bolivianos se aproximava, os interesses das forças políticas envolvidas no conflito entravam em choque. A unidade entre

\footnotetext{
${ }^{33}$ OURIQUE, Jacques. O Amazonas e Acre. Artigos publicados no "Jornal do Commercio". Rio de Janeiro, Typ. Jornal do Commercio, 1907. p. $218-220$.
} 
os "revolucionários" havia sido quebrada. Em carta dirigida ao governador Silvério Nery, Rodrigo de Carvalho afirma:

[. . .] Tenho a dizer a V. Ex ${ }^{\mathrm{a}}$, que descobri grande quantidade de pretendentes a Governador, e a causa acabaria em briga grossa; cortei o nó górdio e combinei com os officiaes em acclamarmos o Plácido governador, com elle entendi-me e exigi-lhe mais este sacrifício; relutou porém cedeu. Fiz cousa bem feita; entendi-me com os candidatos em particular e reservadamente, fazendo-lhes ver que só uma dictadura e que devido ao prestígio adquirido nos combates, só o Plácido poderia sel-o e que elle era a única garantia dos Acreanos, porque os traria sempre unidos e fortes, concordaram todos um por um e ficou assentado ser elle Governador[... $]^{34}$. [grifos nossos]

Portanto, antes da completa rendição dos bolivianos, a disputa pelo poder no futuro

Estado a ser instituído demonstrava claramente que o Amazonas, através da oligarquia dos

Nery, pretendia impor o seu domínio no Aquiri, utilizando a inegável liderança que Plácido de

Castro conseguiu nos campos de batalha.

Com a vitória dos brasileiros, assinava-se o documento de rendição, no qual concordava-se:

$1^{\circ}$ - El señor Delegado Nacional entrega el Puerto y la plaza da guerra, armas, municiones e demais artículos belicos además las oficinas publicas, en el estado en que se encontram en este momento.

$2^{\circ}$ - El jefe de las fuerzas revolucionarias se obliga á garantizar la vida y liberdad de todos os ciudadanos bolivianos que se encuentran en la guarnición dandoles medios de transporte haste Manaos. Puerto Acre, 24 de Enero de $1903 .^{35}$

Rendera-se a Bolívia, ou seja a representação do governo boliviano em Puerto Acre, e a "palavra de ordem" passou a ser organizar o Estado, no Aquiri.

\footnotetext{
${ }^{34}$ Apud LIMA, Cláudio de Araújo, op. Cit. p. 187 In: CALIXTO, Valdir de Oliveira. Plácido de Castro e a construção da ordem no Aquiri (contribuição à história das idéias políticas), p. 201.

${ }^{35}$ CALIXTO, Valdir de Oliveira. Plácido de Castro e a construção da ordem no Aquiri (Contribuição à história das idéias políticas), p. $201-202$.
} 
Os decretos expedidos, os sete primeiros, apresentam os fundamentos erguidos para a estruturação do Estado Independente do Acre.

Decreto $\mathrm{n}^{\mathrm{o}} 1$.

Cidade do Acre [Puerto Alonso], 26 de janeiro de 1903.

José Plácido de Castro, Governador acclamado e Commandante em Chefe do Exército do Estado Independente do Acre.

Decreta:

A justiça civil, a criminal e a comercial do Estado Independente do Acre ficarão sujeitas às disposições dos códigos, leis, decretos, etc, dos E. U. do Brasil até que seja promulgada a sua constituição.

Art. $2^{\circ}$.

Serão válidos os títulos de propriedade definitivos ou provisórios até o presente expedido pela Bolívia ou pelo Estado do Amazonas, antes da ocupação do Acre por esta República.

Art. $3^{\circ}$.

Fica sendo a língua oficial do Estado a portugueza.

Art. $4^{\circ}$.

Fica considerado como typo monetário oficial do Estado Independente do Acre o mesmo dos E. U. do Brasil, sendo o papel moeda dessa paíz válido aqui.

Revogam-se as disposições em contrário. ${ }^{36}$

Este conjunto de artigos não é diferente dos primeiros Decretos expedidos por Galvez em sua efêmera República.

No Estado recém-criado, as leis brasileiras vigorariam até que fosse promulgada a Constituição do Estado Independente. O direito de propriedade é assegurado e as leis bolivianas seriam substituídas pelas leis brasileiras.

De conformidade com a Constituição brasileira de 1891, no seu artigo 64, a propriedade era compreendida da seguinte forma: "[. . . ] pertencem aos Estados as minas e terras devolutas situadas nos seus respectivos territórios, cabendo à União somente a porção de território que por indispensável para a defesa das fronteiras, fortificações, construções militares e estradas de ferro federais" ${ }^{, 37}$.

\footnotetext{
${ }^{36}$ CALIXTO, Valdir de Oliveira. Plácido de Castro e a construção da ordem no Aquiri (Contribuição à história das idéias políticas). Rio Branco: Governo do Estado do Acre/Fundação Elias Mansour, 2003, p. 202 - 203.

${ }^{37}$ Apud. Castro, Genesco de. O Estado Independente do Acre. Rio de Janeiro, 1930. p. 115-120.
} 
Por sua vez, é importante ressaltarmos que nessa época estava em vigor a lei n. 601, de 18.09.1850, que ficou conhecida como a "lei da terra", a qual, no seu artigo 85, expressava que:

Os empresários que pretendessem fazer povoar quaisquer terras devolutas compreendias na zona de dez léguas nos limites do Império com países estrangeiros, importando para elas, à sua custa, colonos nacionais ou estrangeiros deverão dirigir suas propostas ao Governo Imperial, por intermédio do Diretor Geral das Terras Públicas, sob as bases:

1) da concessão aos ditos empresários de dez léguas em quadro ou seu equivalente para cada colônia de mil almas, sendo as terras de cultura, e quatrocentas, sendo campos próprios para a criação de animais; $2^{\circ}$ ) de um subsídio para ajuda da empresa, que será regulado segundo as dificuldades que oferecer ${ }^{38}$.

Frente ao exposto, o Estado Independente do Acre reconhecia como legítimos tanto os títulos de propriedade que foram expedidos até então pela Bolívia quanto os expedidos pelo Estado do Amazonas.

O artigo $\mathrm{n}^{\mathrm{o}} 2$ deixa evidente que a forma de governo a ser instituída seria a República. Uma República liberal, porém diferente da imaginada por Galvez.

Decreto $n^{\circ} 2$.

Art. $1^{\circ}$.

Ficam criadas as Directorias de Fazenda, Justiça e Guerra.

Art. $2^{\circ}$.

A Directoria da Fazenda abrangerá a direção de agricultura e vias terrestres e fluviaes.

Casa do Governo em Porto Acre, 27 de janeiro de $1903^{39}$

Pelo Decreto acima mencionado, cabia ao Estado, por meio da Diretoria da Fazenda, responsabilizar-se não somente pela produção, mas também pela circulação de mercadorias.

Das suas entrelinhas, percebe-se que era propósito de Plácido de Castro, embora sem muito

${ }^{38}$ Modus Vivendi, assinado entre o Ministro Sr Dr. Eliodoro Villazón e o Sr. Eduardo Lisboa, enviado Extraordinário dos Estados Unidos do Brasil. Arquivo Histórico do Itamarati. AHI.

${ }^{39}$ Ibid. p. 204. 
apoio dos seus assessores, estabelecer uma economia diversificada e não apenas centrada no extrativismo.

Ao criar um órgão para zelar pela produção e escoamento da produção, por terra e por vias fluviais, Plácido de Castro almejava retirar o Acre da zona de influência regionalparticularmente do Governo do Amazonas, mas, também, do próprio governo da União, ou seja, do "grupo de oligarquia" para o qual a vida nacional deveria orbitar em torno da produção e exportação de café.

Portanto, a Diretoria da Fazenda se constituía um setor importante para a sobrevivência do novo Estado: o setor de "agricultura e vias terrestres e fluviais". (leia-se cuidar da produção e circulação de mercadorias não necessariamente extrativas).

Nos Decretos de $\mathrm{n}^{\mathrm{o}}$ 3, 4 e 5, destacam-se as questões alusivas aos limites do Estado Independente do Acre; a nomeação para estratégico cargo de Diretor da Fazenda e Inspector da Alfândega, de Rodrigo de Carvalho; e a criação dos juizados de casamento, nascimento e óbitos. No caso dos dois últimos percebe-se a preocupação com a regulamentação das uniões e com a instituição de uma política alfandegária eficaz.

Decreto $\mathrm{n}^{\circ} 3$

Parágrafo Único.

A área do Estado Independente do Acre fica encerrada nos seguintes limites:

Ao Norte, a República Brasileira, pela linha traçada da nascente do Javary à foz do Beni; ao Sudeste, o rio Beni acima da foz até a foz do Orton; deste ponto acima pelo leito de Orton até a confluência do Manuripe com o Tauamano e dahi pelo leito do Manuripe até sua nascente principal; pelo Sul, por uma parallela ao Equador, traçada da nascente do Manuripe à fronteira Peru; revogadas disposições em contrário.

Casa do Governo em Porto Acre, 28 de Janeiro de 1903.

Dançavam, novamente, as linhas. O espaço era reorganizado de modo a atender aos ricos proprietários, agora, juntamente com Plácido de Castro, no poder.

Decreto $n^{\circ} 4$.

Artigo Único.

Fica nomeado Diretor da Fazenda e Inspector da Alfândega, effectivo, o cidadão Rodrigo de Carvalho, que exercia interinamente esse cargo.

Casa do governo em Porto Acre, 28 de janeiro de 1903. 
Decreto $\mathrm{n}^{\circ} 5$.

Art. $1^{\circ}$

Ficam crreados três juizados de casamentos, nascimentos e óbitos: sendo um em Porto Acre, outro em Capatará e outro em Xapury, o Sr. Francisco Simplício Costa ${ }^{40}$.

Os Decretos de $n^{\circ} 6$ e 7 denotam o interesse do novo governo em viabilizar o registro das propriedades na própria região e não mais em Manaus, como anteriormente ocorria, e a nomeação de José de Plácido de Castro para os cargos de governador e comandante-em-chefe do Exército Acreano.

Decreto $\mathrm{n}^{\circ} 6$

Art. $1^{\circ}$.

Ficam creados dois tabellionatos no Acre, sendo um em Porto Acre e outro em Xapury.

Art. $2^{\circ}$.

Ficam nomeados tabeliões interinos, em Porto Acre, Jesuíno Nunes Versosa e em Xapury, o Sr. Augusto S. Pereira, revogadas as disposições em contrário.

Porto Acre, 5 de Março de 1903.

Decreto $n^{\circ} 7$

O coronel José Plácido de Castro, Governador do Estado Independente do Acre e Comandante em Chefe do Exército Acreano:

Considerando:

Que o governo Brasileiro mandou occupar militarmente a zona compreendida entre a linha "Cunha Gomes" e o parallelo de $10^{\circ} 20^{\prime}$.

Considerando:

Que é dever do patriotismo não embaraçar as negociações do Exterior em virtude das quaes se fez a referida ocupação;

E tendo em vista.

Que para reivindicação de nossos direitos conspurcados pelo Governo Boliviano a lucta de vê continuar como até aqui.

Decreta:

Art. $1^{\circ}$.

Fica transferida para a cidade de Xapury a sede do governo do Estado Independente do Acre.

Art. $2^{\circ}$.

Fica transferida provisoriamente a Alfandega do Estado para o logar "Capatará", até que seja determinado o ponto onde o paralelo de $10^{\circ} 20^{\prime}$ cortar o rio Acre.

Porto Acre, 10 de Abril de $1903 .^{41}$

\footnotetext{
${ }^{40}$ Ibid. p. 205

${ }^{41}$ Ibid. p. 205-206
} 
Ainda em relação ao Decreto de $n^{\circ} 7$, observa-se a preocupação de deixar evidente que a "nova ordem" política não pretendia confrontar-se com o governo oligárquico e a ascensão de Xapuri, por tornar-se sede do Estado. Vale ressaltar que essa localidade foi um ponto estratégico-militar importante durante os conflitos armados entre os brasileiros e os bolivianos.

No entanto, a assinatura do Modus Vivendi entre o Brasil e a Bolívia estabeleceu que a parte litigiosa do território seria ocupada por tropas brasileiras e o território ao sul do paralelo $10^{\circ} 20^{\prime}$ ' seria boliviano em "virtude do artigo II do tratado de 27 de março de 1867 ”,

Outro aspecto a considerar é que Plácido de Castro, por "dever de patriotismo", aceitou o acordo e transferiu a administração do Estado Independente para Xapuri. Nesta cidade, quando iniciava as lides da administração do novo Estado foi deposto pelas forças do General Olympio da Silveira, militar designado pelo governo federal para fazer cumprir o estipulado no Modus Vivendi.

Essas eram as instruções que o General deveria cumprir:

O General Olympio da Silveira usará o título de Governador do Acre Setentrional, em nome do Governo Federal. No Acre Meridional, isto é, ao sul do paralelo $10^{\circ} 20^{\prime}$ continuará a exercer a sua autoridade o governo aclamado pelos acreanos. Esse Governo, para que se mantenha a ordem sejam cumpridas as obrigações que o Brasil contraiu com a Bolívia, deverá, durante a intervenção brasileira aceita pelo governo boliviano, proceder em tudo de acordo com os conselhos ou as decisões do General Governador militar do Acre brasileiro. Em vista do acordo de 21 de março, um destacamento de tropas brasileiras passará ao sul do paralelo $10^{\circ} 20^{\prime}$, com o fim de manter a ordem, proteger os brasileiros e evitar o encontro de armas e conflitos entre acreanos e bolivianos. As tropas federais, assim destacadas no sul, ocuparão o Alto Acre, podendo estabelecer postos avançados para oeste, no rio Iquiri e no Rapirrã. Os acreanos continuarão em armas, mas deverão abster-se de assumir a ofensiva contra a Bolívia ${ }^{43}$.

\footnotetext{
${ }^{42}$ A correspondência diplomática trocada entre o Chanceler e seu Plenipotenciário Educudo Lisboa prova que o Barão de Rio Branco já pensava na hipótese da indenização ou compra do território à Bolívia. Arquivo Histórico do Itamarati. AHI.

${ }^{43}$ Ibid. p. 208.
} 
Pelo conteúdo do documento acima citado, podemos inferir que o General governador, ao agir por conta própria, pôs em risco a estratégia do governo Federal, que consistia, fundamentalmente, em contar com a liderança, o espírito guerreiro e os sentimentos patrióticos de Plácido de Castro e seu Exército para manter os bolivianos à distância, na perspectiva de ganhar tempo para a anexação definitiva de toda a região em litígio.

Por sua vez, com o governo Rodrigues Alves que sucedeu a Campos Sales e o Barão do Rio Branco substituindo Olinto de Magalhães na pasta do Ministério das Relações Exteriores, a política externa brasileira assumia cada vez mais os "ares" do panamericanismo.

Importante considerarmos que, embora até 1930, a Inglaterra tenha mantido a sua hegemonia na América Latina e sido a principal parceira comercial e concessora de empréstimos de capital ao Brasil, os Estados Unidos buscam, a partir do advento da República e do desenvolvimento da produção de café e borracha, tornar-se não apenas o principal importador destes produtos, como também estreitar as relações políticas, o que por sua vez correspondia aos interesses dos cafeicultores e da nova visão diplomática do Itamarati, claramente pró-norte-americana.

Para a consolidação dessa postura pan-americana do Itamarati também contribuiu a intensa atividade diplomática de Joaquim Nabuco junto ao governo de Washington, pois para este: “a América, graças à Doutrina Monroe, é o Continente da Paz, e essa colossal unidade pacificadora interessando fundamente outras regiões da terra - todo o Pacífico a bem dizer -, forma um Hemisfério Neutro e contrabalança o outro Hemisfério, o que bem poderíamos chamar o Hemisfério Beligerante" ${ }^{, 4}$.

\footnotetext{
${ }^{44}$ Arquivo Histórico do Ministério do Exército. In: CALIXTO, Valdir de Oliveira. Plácido de Castro e a construção da ordem no Aquiri (contribuição a história das idéias políticas). Rio Branco: Governo do Estado do Acre / Fundação Elias Mansour, 2003. p. 209.
} 
O alinhamento aos interesses americanos, a aceitação da Doutrina de Monroe passaram, desde então, a expressar a posição do governo oligárquico brasileiro, embora houvessem vozes discordantes como as de Rui Barbosa, Lúcio de Azevedo e outros.

Considerando os aspectos anteriormente focalizados, a estratégia de ação do Barão de Rio Branco em relação a questão do Acre concentrou-se em dois pontos fundamentais: o primeiro, não romper com os Estados Unidos frente as suas pretensões de expansão em direção aquela região. Segundo, manter-se alerta para impedir que a soberania do Brasil fosse prejudicada em meio ao fogo cruzado dos interesses em pauta.

Outro aspecto a destacar é a ingerência norte-americana nos assuntos internos do Brasil, tanto que Assis Brasil, que sucedeu Joaquim Nabuco na condição de Plenipotenciário em Washington, em relação à questão do Acre, diz que "não simpatizo com o contínuo recurso à influência Yanke, seguro meio de fortalecer além da já exagerada que ela naturalmente tem. Sou amigo dos Estados Unidos e quisera ver o Brasil em estreita aliança com este país, mas tomando a cautela sistemática de o afastar dos seus negócios" ${ }^{\natural 5}$ [Grifo nosso]

Manter Plácido de Castro sob controle, sem desarmá-lo, era a perspectiva porém não permitindo que a questão do Acre levasse a um confronto armado com o Bolivian Syndicate, corporação de capital norte-americano que estava por trás da Bolívia e funcionava como uma "testa de ferro" desta. Integrar o Acre à federação brasileira não significava conceder autonomia aos grandes proprietários dos seringais do Acre e seus representantes na Junta

\section{Revolucionária.}

No entanto, o General Olympio da Silveira, ignorando os meandros da questão, em 13 de maio de 1903, proclamando a Ordem à sua maneira, depôs Plácido de Castro do Governo do Acre Meridional.

\footnotetext{
${ }^{45}$ Arquivo Histórico do Exército. AHE. A repreensão partira do Coronel Raphael Augusto da Cunha Matos, novo comandante em Chefe e Governador Militar do Acre Setentrional. AHE. In: CALIXTO, Valdir de Oliveira. Plácido de Castro e a construção da ordem no Aquiri (contribuição à história das idéias políticas). Rio Branco:>Governo do Estado do Acre / Fundação Elias Mansour, 2003. p. 210.
} 
Proclamação

O General Antônio Olympio da Silveira, Governador do Acre Septentrional e Commandante em Chefe das Forças Federaes de ocupação.

Considerando que a quase totalidade do exército acreano revoltou-se contra o coronel José Plácido de Castro e seus auxiliares.

Considerando que este Chefe, levado por sentimentos de patriotismo que muito o recomenda a benemrencia da sua amada Pátria, declarou retirar-se d'este Território e não querer tentar represálias afim de evitar uma lucta fratricida, deixando ao Exército Nacional a guarda do mesmo território, conforme ficou estabelecido no Convenio de 21 de Março findo.

Considerando que em vista d'esta declaração do Coronel Plácido de Castro e da aprezentação a este governo dos officiaes e praças de quase toda a força acreana, está extinta a Revolução.

Quartel General na Boa Fé, 13 de Maio de $1903^{46}$

Esta atitude autoritária, intolerante e desrespeitosa a Plácido de Castro que comandara os acreanos na luta contra a Bolívia e seu agente financeiro, o Bolivian Syndicate não foi acatada pelo governo brasileiro, sendo Plácido reconduzido ao governo do Acre Meridional.

A visão política de Plácido de Castro e sua prática administrativa compreendia que a ordem, a lei, a justiça e a liberdade deveriam ser os fundamentos do Estado.

Em um documento encaminhado ao Delegado do Alto Acre, Wenceslau Salinas chamava a atenção ao Delegado Especial que ficasse atento à imigração indígena para o Acre, especialmente por serem estes tratados como

[. . .]"verdadeiros escravos" por "senhores bárbaros", - brasileiros ou bolivianos, migram para o Acre, esperando "amplas garantias de suas leis". É preciso, pois, coibir abusos de proprietários que, "como dantes", seguem a mesma política escandaloza de proceder [. . .] impondo a seus fregueses os mesmos costumes bárbaros [. . .] como sejam, flagelação, rapto das mulheres aos maridos, dos filhos aos paes, e obrigar os mesmos a trabalhos penosos, impostos pelo azurrague, sem attender às condições phisicas de cada um, roubando-lhes ainda a liberdade de retirar-se para onde lhes for conveniente, constituindo assim uma verdadeira escravatura, o que não pode ser admitido no seio de um povo livre, que tem com lema a justiça e que se tem sacrificado pela sua liberdade ${ }^{47}$

\footnotetext{
${ }^{46}$ Arquivo Nacional, SPE Códice 988 In: CALIXTO, Valdir de Oliveira. Plácido de Castro e a construção da ordem no Aquiri: (contribuição à história das idéias políticas). Rio Branco: Governo do Estado do Acre / Fundação Elias Mansour, 2003, p. 211.

47 Arquivo Nacional, SPE 001, Códice 988 In: CALIXTO, Valdir de Oliveira. Plácido de Castro e a construção da ordem no Aquiri (contribuição à história das idéias políticas). Rio Branco: Governo do Estado do Acre / Fundação Elias Mansour, 2003, p. 212.
} 
Um outro documento é também revelador da preocupação do governo de Plácido de Castro em coibir atos que se contraponham aos princípios do progresso, da liberdade, da justiça e da ordem nas relações de trabalho.

Trata-se de um ofício enviado pelo Coronel Hyppoito Moreira, Delegado Especial, ao sr. José Monteiro Maia, Delegado da $1^{\mathrm{a}}$ Circunscrição do rio Iaco, no qual o Delegado Especial comunica ao recém-nomeado Delegado da $1^{\mathrm{a}}$ circunscrição que

[procedesse] com escrúpulo, calma e reflexão, prestigiando as leis e todos os atos do nosso Governo [. . .] toda solicitude na maneira com que os patrões e os fregueses liquidam entre si suas contas, devendo "[proceder] de modo que não [houvesse] de qualquer parte interesses lesados; e na hyphotese de um patrão aliciar ou aceitar qualquer freguez, [devia] ser absolutamente responsável por todas as dívidas deste para com o patrão abandonado" $"$.

Plácido de Castro marcou a sua prática administrativa buscando materializar os elementos essenciais a sua visão de mundo, do político, em que se destacavam o caráter não separatista, a obediência a "pátria brasileira", a aversão aos poderosos Estados Unidos e, por fim, a sua oposição a política externa da República oligárquica cafeeira, de franco alinhamento a Washington.

Retornando o contexto pós rendição da Bolívia e organização do Estado Independente do Acre por Plácido de Castro, ressaltamos que em 18 de novembro de 1903, mas com data do dia anterior, no Palácio Westfalia, Fernando Guachala e Cláudio Pinilla, pela Bolívia, Rio Branco e Assis Brasil, em nome do Brasil foi assinado Tratado de Petrópolis.

O espaço geográfico banhado pelos rio Acre, Purus, Iaco e Javary tornou-se Território Federal. 
Em exposição perante a Câmara, o ministro Rio Branco enfatizou:

Pelo presente Tratado o Brasil incorpora ao seu patrimônio um território mais extenso que de qualquer dos Estados do Ceará, Rio Grande do Norte, Paraíba, Pernambuco, Alagoas, Sergipe, Espírito Santo, Rio de Janeiro e Santa Catarina, território que produz renda anual superior a mais da metade dos vinte Estados da nossa União. Não foram, porém vantagens materiais de qualquer ordem o móvel que nos inspirou. Desde muito se conheciam as riquezas do Acre, que eram os nossos compatriotas os únicos a explorar. Entretanto, o Governo persistiu sempre em considerar boliviano aquele território e dar à Bolívia as possíveis facilidades para o utilizar. Foi preciso que a própria segurança deste Continente fosse ameaçada pela introdução do sistema perturbador das chartered companies, e que nos convencêssemos da impossibilidade de conservar as boas relações, a que tanto prezamos, com a nação boliviana, enquanto existisse sob a sua soberania um território exclusivamente habitado por brasileiros que lhe eram hostis, para que produzisse a nossa ação em busca dos resultados agora obtidos.

[...] O Brasil incorpora 181.000 quilômetros quadrados de terra, e em troca a Bolívia recebe:

723 quilômetros quadrados sobre a margem direita do rio Paraguai, dentro dos terrenos conhecidos por Baía Negra;

116 quilômetros sobre a lagoa de Cárcere, compreendendo uma nesga de terra firma (49,6 quilômetros quadrados) que permite o estabelecimento de um ancoradouro mais favorável ao comércio que o que fora cedido à Bolívia em 1867;

20,3 quilômetros quadrados, nas mesmas condições, sobre a lagoa Mandiré; 8,2 quilômetros quadrados sobre a margem meridional da Lagoa Guaíba;

A construção de uma estrada de ferro, em território brasileiro, ligando Santo Antônio, no Madeira, a Vila Bela, na confluência do Beni e Marmoré.

Liberdade de trânsito por essa estrada e pelos rios até o oceano, com as correspondentes facilidades aduaneiras, o que já lhe era facultado por anteriores Tratados.

Finalmente, o pagamento de dois milhões de libras esterlinas em duas prestações.

Era uma completa espoliação feita aos acreanos. Veio-me à mente a idéia cruel de que a Pátria Brasileira se ia desmembrar, pois, ao meu ver, aquillo não era mais do que o caminho que os Estados Unidos abriam para futuros planos, forçando-nos desde então a lhes franquear à navegação os nossos rios inclusive o Acre. Qualquer resistência por parte do Brasil ensejaria aos poderosos Estados Unidos o emprego da força, e a nossa desgraça em breve estaria consumada. Guardei, apressado, a bússola de Castella, de que me estava servindo, abandonei as balizas e demais utensílios sahi no mesmo dia para a margem do Acre $^{49}$ [Grifos nossos]

${ }^{49}$ TOCANTINS, Leandro. Op. Cit. p. 274. In: CALIXTO, Valdir de Oliveira. Plácido de Castro e a construção da ordem no Aquiri (contribuição à história das idéias políticas). Rio Branco: Governo do Estado do Acre / Fundação Elias Mansour, 2003. p. 215. 
O Tratado repercutiu em todo o Brasil. No Aquiri, os patrões, sobretudo os que participaram da luta armada contra os bolivianos receberam a notícia com satisfação. Com este fato, a breve experiência histórica do Estado Independente do Acre Meridional encerrouse.

No entanto, a conformação geográfica do Acre não estava concluída, pois permanecia em aberto a questão com o Peru.

O fato é que as linhas teóricas do Tratado espanhol/português de Santo Ildefonso criou a ilusão de vastos limites orientais. No entanto, o expansionismo nacional e o domínio sobre a parte baixa dos rios amazônicos favoreciam a possessão brasileira. Em 1841, 1851 e 1858, o Peru teve que reconhecer um uti possidetis de fato para o Brasil.

Para uma definição do litígio entre o Brasil e o Peru vários fatores contribuíram: o reconhecimento do Brasil acerca das pretensões da Bolívia em 1867 mediante o Tratado Muñoz - Netto; a descoberta do rio Javary por uma comissão de 1874, em uma situação geográfica que os negociadores de 1851 não haviam suspeitado; a retificação do cálculo deste pelo brasileiro Cunha Gomes em 1897, dando ao Brasil 1.200 Km2 de território; a negativa do governo do Peru para enviar uma expedição ao Acre em 1901; o Tratado de Petrópolis firmado em 1903 entre a Bolívia e o Brasil e o Modus Vivendi peruano brasileiro de 1904 que neutralizou a disputa do Alto Juruá e Alto Purus.

Como desdobramento das questões acima mencionadas, mediante o Tratado assinado no Rio de Janeiro em 8 de setembro de 1909, tendo de um lado, José Maria da Silva Paranhos, o Barão de Rio Branco e do outro o representante do Peru, Hernán Velarde se completou a demarcação dos limites entre o Brasil e o Peru que se iniciara com a convenção fluvial sobre o comércio e a navegação de 1851, na direção do Norte, desde a nascente do Javari até o rio Caquetá ou Yapurá. 
Este Tratado também estabeleceu uma comissão mista para a demarcação das linhas fronteiriças e deu algumas normas para seu funcionamento. Também fixou normas para impedir o contrabando.

Por sua vez, ainda ratificou o princípio da mais ampla liberdade de trânsito terrestre e navegação fluvial para ambas as nações em todo o curso dos rios que nascem ou correm dentro ou nas extremidades da região atravessada pelas ditas linhas. Em 10 de janeiro de 1910, o referido Tratado foi aprovado pelo Congresso Peruano.

Encerrando-se a questão com o Peru, os limites geográficos do Acre estavam definidos e o Estado brasileiro e as elites nacionais, para legitimar a luta dos patrões por um Acre brasileiro, a transformaram em "Revolução Acreana", num contexto marcado pela produção historiográfica positivista.

A esse respeito, com base na pesquisa realizada consideramos que a luta que se desenvolveu para a anexação do Acre ao território brasileiro se configura uma guerra de fronteiras por limites, e não uma revolução, a qual envolveu o Brasil, a Bolívia e o Peru num contexto mundial marcado pela expansão da industrialização e a busca por mercados fornecedores de borracha para atender as necessidades da indústria européia e norteamericana gerando a inserção do Acre na economia-mundo.

A "Revolução Acreana" transforma-se no discurso fundador do Acre e a construção da identidade do Acre como território brasileiro se insere no universo da tradição inventada, tendo como simbologia de maior expressão o hino acreano.

Portanto, coerente com a nossa proposta de incorporar a Introdução à estrutura da tese como um todo, superando o modelo monográfico, os quatro capítulos que a integram estão articulados da seguinte forma:

No primeiro capítulo, A invenção do Acre brasileiro, buscamos reconstituir as bases do poder local frente aos limites impostos pelo governo da União, bem como demonstrar que 
o Movimento Autonomista possibilitou a invenção de um outro Acre - independente politicamente.

O segundo capítulo, A invenção do Acre emancipado, está centrado no processo de elevação do Acre a Estado e no imaginário político das forças que inventaram o Estado, destacando nesse processo a tramitação do projeto de Guiomard Santos e a participação das legionárias do Acre, na emancipação do Acre.

No terceiro capítulo, os partidos políticos e a memória dos militantes acreanos, com base na literatura existente sobre os partidos políticos no Brasil produzimos um enquadramento histórico para a contextualização das falas dos militantes acreanos, acerca tanto da questão da elevação do Acre a Estado, quanto da conjuntura política da época.

No quarto capítulo, a invenção do Acre viável, a perspectiva é, de um lado, discutir as novas representações da autonomia acreana, tendo como elemento central o cultural, e do outro, caracterizar o processo de invenção do Acre viável como algo aberto, dinâmico e em permanente mutação, na medida que dá-se numa fase peculiar da economia capitalista mundial.

Importante destacarmos o pioneirismo desta tese em relação ao Acre, na medida que busca desconstruir o discurso político da questão do Acre como revolução, o qual foi legitimado pela historiografia tradicional, por outro lado, trás a tona aspectos da história do Acre ainda não contemplados pela produção acadêmica, quais sejam: o movimento autonomista, a participação das mulheres na causa emancipacionista acreana, o resgate das memórias dos militantes políticos do PSD, PTB, UDN e PCB nos anos 60 e 70 e a discussão da viabilidade do Acre. 


\section{CAPÍTULO I: A INVENÇÃO DO ACRE BRASILEIRO}

Para ninguém é mais doloroso do que para nós vir dizer do paiz na qualidade de colonos do extrangeiro cujo jugo sacudimos, tínhamos mais direitos que temos hoje na communhão brasileira!.

José Plácido de Castro

Com as celebrações dos Tratados de Petrópolis e do Rio de Janeiro, tem início a invenção do Acre brasileiro. E um dos seus elementos constituinte foi a construção da Ordem. E a quem caberia esta missão? Ao governo federal brasileiro, ao governo do Estado do Amazonas ou ao movimento autonomista acreano.

Nessa disputa pelo poder, o Congresso Nacional solucionou o impasse através da instituição do sistema de Território Federal, através do qual o Acre passou a ser administrado pelo governo da União, sendo postergadas as aspirações do Amazonas e dos políticos que integravam o movimento autonomista que defendia a anexação do Acre ao Brasil na condição de Estado da Federação brasileira com plenos poderes políticos.

Dessa forma, a República brasileira tomando para si a tarefa da construção da Ordem no Acre, transformou-o numa propriedade da União, pois este nem era Estado nem província. Importante considerarmos ainda que a forma como o Acre foi incorporado ao Brasil se constituiu uma excrescência jurídica do ponto de vista da primeira Constituição Republicana, que preceituava a transformação de "cada uma das antigas províncias em Estado",50.

Vale acrescentar que para alguns juristas brasileiros e historiadores a fórmula encontrada pelo governo brasileiro para transformar o Acre em território foi importada da Constituição dos Estados Unidos da América.

${ }^{50}$ ALMEIDA, Fernando H. Mendes (org.) Constituições do Brasil. São Paulo: Saraiva, 1954, p. 109. 
$\mathrm{Na}$ época do levante contra a Bolívia era o Território uma das regiões brasileiras que mais contribuíram para os cofres públicos. Em pouco tempo com as rendas do Acre foram cobertas todas as despesas decorrentes do Tratado de Petrópolis. [. . .] O Acre, Sr. Presidente, Srs. Deputados tem origem diversa dos outros territórios. Foi até Estado Independente. [. . . O Acre se fez brasileiro por si mesmo ${ }^{51}$.

No entanto, Craveiro Costa nos mostra que, mesmo nos E.U.A., a instituição do sistema de Território se constitui uma exceção e foi utilizado

nos casos dos territórios americanos do Alasca, Nova México, Havaí e Arizona, devido suas populações, na época da anexação serem estranhas à nacionalidade da Grande República. [. . .] Quando os territórios de Oklaoma e Indiana atingiram a prosperidade desejável, passaram juntos a formar um novo Estado, aumentando os Estados Unidos em sua bandeira mais uma estrela simbólica ${ }^{52}$.

Embora as aspirações emancipacionistas dos que integravam o Movimento Autonomista tivessem sido soterradas pelo governo brasileiro, o Movimento Autonomista se fortaleceu e expandiu-se por todo o território acreano através da ação de organizações diversas, tais como: Partido Autonomista do Alto Acre, Partido Autonomista do Alto Juruá, Clube Político de 24 de Janeiro de Xapuri, Partido Republicano do Acre Federal, no Alto Purus e Alto Acre, Partido Evolucionista de Rio Branco, Comitê Pró-Autonomia de Rio Branco, Legião Autonomista Acreana, em Rio Branco e nos demais municípios do Acre e o Comitê Pró-Autonomista do Acre, também localizado em Rio Branco, os quais canalizaram os interesses das forças políticas locais e deram livre expansão ao propósito de constituição de um Acre emancipado.

Como essa instituição do Acre brasileiro foi legitimada pelas forças políticas que o inventaram?

\footnotetext{
${ }^{51}$ SANTOS, José Guiomard. Cinqüentenário do Tratado de Petrópolis. Mensagem do Acre. Discurso preferido na sessão da Câmara Federal, em 17 de novembro de 1953, em nome da Maioria. In: BEZERRA, Maria José. Dossiê - Acerbo: Guiomard Santos (Acre) Elevação do Acre a Estado. Rio Branco, 1992. p. 49 - 50.

${ }^{52}$ COSTA, João Craveiro. A conquista do Deserto Ocidental. São Paulo: Nacional, Brasília: INL, 1973, p. 120.
} 
O discurso oficial da República oligárquica brasileira transformou a luta dos acreanos em "Revolução Acreana" e os que participaram desta são nomeados, numa linguagem eivada de simbolismos, de heróicos, bravos, destemidos, invencíveis, grandes na guerra, valores nobres. .

E como expressão do ritual de unção do Acre brasileiro foram criados como símbolos o Hino Acreano, a Bandeira Acreana e o Escudo Acreano.

O nascimento do Acre institui um mundo de significações e, ao fazê-lo, institui a si mesmo instituindo um mundo de significações, as quais visam dar e manter a coesão do mesmo.

O Acre não existiria sem ser instituinte e instituído. E sua instituição dependia das significações. E as significações se impõem pela linguagem, que é um código.

Esses signos se constituem a tradição inventada, os quais têm como função não apenas cristalizar o momento de invenção do Acre brasileiro, mas incutir valores, crenças e normas de comportamento através seja da repetição, no caso do Hino Acreano, seja por meio de visualização reverenciosa nas condições de ícones sagrados do Acre.

O Hino Acreano, cuja letra foi composta por Francisco Cavalcanti Mangabeira, médico e poeta, em 5 de outubro de 1903, no acampamento do seringal Capatará, localizado acima do Igarapé Distração, na cidade de Rio Branco, sendo a Música de autoria de Mozart Donizeti, maestro amazonense, é exemplo de uma tradição característica de uma visão de mundo, de sociedade, de história.

Que este sol a brilhar soberano

Sobre as matas que o vêem com amor

Encha o peito de cada acreano

De nobreza, constância e valor. . .

Invencivel e grandes na guerra

Imitemos o exemplo sem par

Do amplo rio que brilha com a terra

Vence-a entra brigando com o mar $^{53}$ [Grifos nossos]

${ }^{53}$ MANGABEIRA, Francisco, DONIZETI, Mozart. Hino Acreano. 1903. 
Dessa forma, o Hino Acreano é a representação do passado construída a partir de um olhar positivista que se coaduna com os postulados patrióticos que a República brasileira defende.

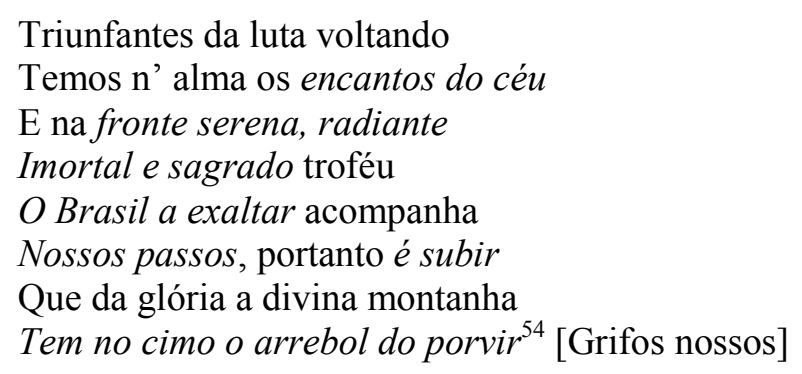

Escrito numa linguagem carregada de simbolismos, marca e apresenta o nascimento do Acre e dos acreanos. E sua repetição nas festividades cívicas e políticas formaliza e ritualiza o passado, ressignificando-o frente aos embates do presente.

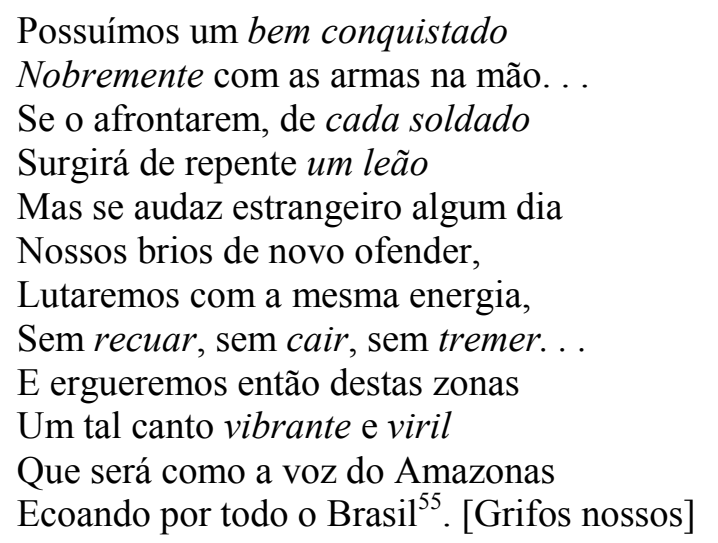

Quanto à Bandeira Acreana, enquanto símbolo da paz e esperança, foi idealizada por José Plácido de Castro, que adotou o mesmo pavilhão criado por Dom Luiz Galvez Rodrigues de Arias, que constava de dois triângulos (verde e amarelo). Plácido de Castro acrescentou-lhe uma estrela rubra na diagonal amarela, por sugestão de Rodrigo de Carvalho. O governador do Acre-Território, Epaminondas Jácome, adotou oficialmente o signo criado por Plácido de

\footnotetext{
${ }^{54}$ Ibid.

${ }^{55}$ Ibid.
} 
Castro. De maneira metafórica e poética, o Acre passou a ser "um astro na nossa bandeira / Que foi tinto com sangue de heróis / Adoremos na estrela altaneira / O mais belo e o melhor dos faróis ${ }^{, 56}$. [Grifos nossos]

O discurso cristão-católico e patriótico do Estado brasileiro republicano está presente na construção do Acre brasileiro. E, assim como o sangue de Cristo nos liberta de todo o mal, o derramamento do sangue dos acreanos os torna não só heróis, mais imunes ao mal, predestinados ao progresso. Os acreanos são divinizados por sua coragem, audácia e brasilidade.

Por sua vez, o escudo acreano instituído como emblema oficial em 24 de maio de 1922, durante a gestão do governo Epaminondas Jácome, configura a representação dos embates militares entre brasileiros e bolivianos e a celebração da vitória sobre o estrangeiro.

[. . . ] nossa campanha de reivindicação, iniciada a 6 de agosto de 1902, em Xapuri, terminada de fato em 24 de janeiro de 1903, em Porto Acre, e sancionada, a 17 de novembro de 1903, pelo Tratado de Petrópolis, adotaram os acreanos como fanal uma estrela rubra e solitária, simbolizando a patriótica aspiração de que ele viesse também um dia, autônoma, unir-se à constelação que na bandeira brasileira representa os seus Estados e o Distrito Federal, onde não brilha menos que as demais (NEC LUCEO PLURIBUS IMPAR) $^{57}$. [Grifos nossos]

Neste mesmo documento, o imaginário do Acre como selva é utilizado pelo poder político para justificar a sua conquista, ocupação, exploração e integração ao território nacional como alternativa de fazê-lo alcançar o progresso.

[...] sua história própria repleta de episódios gloriosos em que os acreanos levaram até os demais ingentes sacrifícios de vida e sangue, a demonstração de seu amor a pátria brasileira já afrontando o mistério das densas florestas virgens, sujeito às emboscadas traiçoeiras dos selvícolas ou as moléstias, já reconquistada, palmo a palmo, de armas na mão, do estrangeiro invasor, esse trecho rico e precioso do Brasil $^{58}$. [Grifos nossos]

\footnotetext{
56 Ibid.

${ }^{57}$ JÁCOME, Epaminondas, CONDE, Francisco de Oliveira. Resolução no 45, 24 de maio de 1922.

${ }^{58}$ Ibid.
} 
Passando o Acre a ser considerado Território Federal, foi organizado administrativamente em três Departamentos: Alto Acre, Alto Purus e Alto Juruá.

O Departamento do Alto Acre, com sede em Rio Branco incluía a região banhada pelos rios Abunã, Rapirran, Iquiri, Alto Acre e Alto Antimary.

Seu primeiro Prefeito, o Coronel Rafael Augusto de Cunha Matos, assinala "que acceitei o difficil e espinhoso encargo antes mais uma vez dar provas de disciplina militar do que pelo desejo de occupar um cargo administrativo reconhecidamente superior as minhas débeis forças" ${ }^{\circ 9}$.

O Departamento do Alto Purus tinha sua sede em Sena Madureira sendo constituído por toda a região marcada pelos rios Iaco, Purus e seus afluentes.

Seu primeiro prefeito foi o General Siqueira de Menezes. Localizada as margens do Rio Iaco, afluente do Rio Purus, nas terras do Seringal Santa Fé, Sena Madureira foi alvo de alguns investimentos de ordem pública, sendo em 1908, instalado o primeiro tribunal de Apelação do Acre, uma Seção da Justiça Federal, uma administração dos Correios, uma Delegacia Federal do Tesouro Nacional, uma Delegacia de Telégrafos e uma Inspetoria Agrícola. Anos depois (1914), teve acesso à iluminação pública e um hospital e foi transitoriamente sede do governo do Território do Acre.

O Departamento do Alto Juruá abrangia toda a área do Alto Juruá, o rio Tarauacá e os afluentes de ambos. Teve como sede Cruzeiro do Sul e seu primeiro prefeito foi o General Thaumaturgo de Azevedo. Esta região foi palco de conflitos tanto contra os invasores "caucheiros" peruanos quanto em relação à emancipação do Acre, na medida que o Movimento Autonomista nesta localidade adquiriu um caráter mais aguerrido, tanto que, em 1910, o governo institucional foi deposto e por 100 dias as forças políticas de Cruzeiro do Sul, através de uma junta composta por abastados seringalistas, governaram o Departamento.

\footnotetext{
${ }^{59}$ MATTOS, Raphael Augusto Cunha. Relatório Apresentado ao Exmo. Sr. Dr. José Joaquim Seabra, Digno Ministro da Justiça e Negócios Interiores pelo Coronel de Armas de Infantaria Raphael Augusto de Cunha Mattos (20.01.1904). Vila Rio Branco. Prefeitura do Alto Acre, 1904, p. 1.
} 
Estes Departamentos Administrativos foram governados por Prefeitos nomeados pelo Presidente da República e tinham a responsabilidade de gerenciar as questões de ordem jurídico-político-administrativa referentes a cada Departamento. Eram subordinados, em primeira instância, ao Ministério da Justiça e Negócios Interiores e, em seguida, ao Presidente da República.

Vale destacar que no Congresso Nacional, a elevação do Acre a condição de Território provocou debates entre os parlamentares, notadamente entre os nordestinos, e destes com ênfase maior para os cearenses, e do Rio Grande do Sul, os quais, em suas falas e projetos, demonstravam comungar dos mesmos ideais dos acreanos - o Acre deveria ser autônomo.

Em nível local, os intelectuais e representantes dos seringalistas, entre os quais Mâncio Lima, Craveiro Costa, Francisco Freire de Carvalho, João Bussons, buscaram, inclusive, no Direito Constitucional Internacional, fundamentos para engrossar as fileiras dos que defendiam a emancipação política.

Para grande parte dos legisladores brasileiros, o Acre, naquele momento, não possuía as condições sociais, educativas e administrativas para ser considerado um Estado Autônomo.

Importante considerarmos que, nesta fase histórica a produção econômica do Acre ocupava o terceiro lugar no País, só perdendo para São Paulo e Minas Gerais. Em termos de densidade geográfica, possuía percentuais superiores aos do Estado do Amazonas, Mato Grosso e Pará. No entanto, no que se referia ao ensino, urbanização, comunicações e transporte, as condições acreanas eram as mais precárias possíveis.

Em 1905, o Prefeito do Departamento do Alto Acre, com sede em Rio Branco, em seu Relatório ao Governo Federal, assinala que:

Resolvi constituir provisoriamente a alludida sede nesta villa onde de chegado podia dispor de barracas e barracões para acommodar pessoal e material. Infelizmente a despeito das providencias tomadas para que menos insalubre se tornasse esta localidade, a malaria e o beri-beri não nos 
abandonaram um só dia e cada um que se passava era mais um que me convencia da mudança da sede do governo para Xapuri [...]

A Secretaria da Prefeitura acha-se installada em um grande barracão de propriedade do cidadão Leon Hersch que m'o cedeu gratuitamente até 31 findo, devendo a Prefeitura d' ora em diante, pagar um aluguel.[. . .] É de madeira como todos os outros, cobertos com telha de zinco, contendo doze compartimentos de grandes dimensões [. . .] A falta de communicações entre os numerosos povoados do Departamento acarreta não pequeno prejuízo à respectiva população, principalmente na época da vazante, em que os rios não podem ser navegados senão por canoas [. . .] Quanto aos trabalhos de seneamento, difficilmente se poderá, por enquanto, fazer alguma cousa, por isso que a população acha-se disseminada e a simples drenagem do solo exige estradas que importam em grandes sommas. [. . .] E quanto a edificações é quase impossível construir em alvenaria, pois tudo teria que ser importado [. . .] a madeira preparada attinge sempre preço elevado [. . .] casas de apparencia modesta que custaram a seus donos fortes sommas. [. . .] E convém levar ainda em conta as moléstias que são inclementes com os que se expõem ao sol e a chuva [...] A instrução pública é ministrada em duas aulas mixtas do primeiro grao [. . .] não obstante o número de crianças de ambos os sexos ser grande e a ignorância ser quasi geral entre menores e adultos. Villa Rio Branco tem 204 habitantes, 129 homens e 75 mulheres; sabem ler e escrever 50 e são analphabetos 154 [. . .] é simplesmente péssimo o sistema de alimentação, onde o pão e a carne verde raríssimas vezes figuravam, mas onde sempre há grande profusão de conservas más, carne seca, farinha d'água, feijão e arroz em geral deteriorados durante o verão. [. . .] com grande sacrifício de minha saúde tenho me conservado neste espinhoso posto que immerecidamente me foi confiado e do qual já por mais de uma pedi demissão que esperançoso aguardo [. . . ] não sendo menos verdade que essa demissão me darei por bem recompensado dos insignificantes serviços que com boa vontade já por duas vezes tenho prestado neste território ingrato, onde os poucos que escapam com vida totalmente retiram-se sem saúde ${ }^{60}$ [Grifos nossos]

Inventar o Acre brasileiro, instituir a civilidade, nas primeiras décadas do século XX era tarefa difícil e penosa que demandava tempo, recursos e pessoal técnico.

E, nesse contexto, o debate sobre a questão da autonomia do Acre crescia possibilitando que opositores e defensores apresentassem os seus argumentos. O sociólogo Oliveira Viana enfatizava que "a única forma de poder público a realizar-se no Acre [. . .] seria não um governo livre, autônomo, descentralizado, emanado do escrutínio da própria

${ }^{60}$ Ibid. p. 121. 
soberania local; ao contrário, feito e aparelhado aqui, absolutamente estranho aquela população",61

Corporificando as reivindicações pela autonomia do Acre, em 1905, o deputado federal cearense Francisco de Sá apresenta à Câmara Federal um projeto que defendia a transformação do Acre em Estado, tendo sido derrotado por maioria.

Enquanto isto, a postura do governo brasileiro de não acatar a reivindicação das forças políticas locais quanto à autonomia política do Acre sofre duras críticas de Plácido de Castro, que, na condição de prefeito interino do Departamento do Alto Acre, enfatiza:

Ao contrário da trilha habitualmente seguida pelos Prefeitos do Território do Acre em seus relatórios da discriminação em phrases bombásticas do desenvolvimento sorprehendente das Prefeituras a seu cargo [. . . ] deixaremos que se veja "a nudez forte da verdade", o abandono extremo que foram atirados, pela incúria de uns e pela desonestidade de outros, os interesses da União; a depredação de suas rendas, a incapacidade administrativa de seus representantes. [. . . Pouco fizemos, mas ao menos conseguimos manter os princípios de segurança e liberdade públicas. [. . .] tanto diremos da ordem pública que se manteve sem a menor alteração [. . .] a despeito dos muitos boatos espalhados em Manaos e dahi por todo o Paiz, de graves movimentos revolucionários [. . .] Convenha V. Ex. em que para ninguém é mais doloroso do que para nós vir dizer que na qualidade de colonos do extrangeiro, cujo jugo sacudimos, tínhamos mais direitos do que temos hoje na communhão brasileira. Tínhamos direito de voto, embora não nos utilizássemos deste porque antes de tudo éramos brasileiros; a nossa borracha que constitui a nossa opulência e que tem sido, talvez, a causa dos nossos soffrimentos, como o ouro foi a da desgraça do Transwaal, era taxada em 15 por cento, com promessa a ser baixada a 12 por cento, como é actualmente na Bolívia, e a nossa importação pagava apenas 15 por cento ad-valorem. Hoje sob denominação de soberania brasileira não temos direito de voto, nem Tribunal, nem hábeas corpus e por conseguinte não temos existência política na communhão nacional; o nosso produto de exportação paga 23 por cento de imposto, os impostos de indústrias e profusões são cobrados sem regulamentação especial, e, além de tudo, transformada a região dos nossos lares em um corpo de guarda. Arredados de todas as posições oficiais, tyranizados pelos dirigentes de nossos destinos em nome do governo da República, a nossa lastimável situação nos traz a idea de que somos um povo extranho, vencido pela força e cuja índole propensa as revoltas, aconselhasse expcepcionaes medidas de repressão. Travada a luta do Acre com a Bolívia, interveio o Brasil em nome do direito dos Acreanos e dos próprios sentimentos de nobreza peculiares ao caracter da nossa nacionalidade [. . .] Esperavamnos, entretanto, múltiplos dissabores; a decepção, o martyrio, o sobressalto

${ }^{61}$ COSTA, João Craveiro. A Conquista do Deserto Ocidental. São Paulo: Nacional, Brasília: INL, 1973, p. 30. 
da possibilidade de annexação de seus lares queridos ao Estado do Amazonas - o que seria para elles o território epílogo de suas desgraças. [. . .] Os acreanos [. . .] tem consciência de sua afflictiva situação e [. . .] o que vê no Acre "é a exploração da terra e a expoliação do homem ${ }^{62}$. [Grifo nosso].

Frente a um testemunho tão pungente expresso por Plácido de Castro, ungido pela história oficial como herói do Acre, fica visível o descontentamento dos seringalistas, os patrões, com o tratamento recebido do governo federal. Seu discurso defende os interesses dos proprietários de seringais, até porque tornara-se proprietário também.

Diante das lamentações e reivindicações dos autonomistas acreanos, o Presidente Afonso Pena, em 8 de março de 1907 criou uma Comissão de Obras Federais para realizar trabalhos referentes a abertura de estradas, desobstrução de rios, construção de obras públicas e defesa militar do Território. A referida comissão, que durou três anos e não concluiu as atividades iniciadas, constituindo-se um fracasso, é um exemplo de incúria administrativa quanto ao uso do dinheiro público.

Em 1908, através do Decreto n. 6.901, o Presidente Afonso Pena buscou melhorar o sistema judiciário, regularizar a propriedade da terra e promover o ensino público primário. No campo da justiça, criou o primeiro Tribunal de Apelação em Sena Madureira e em cada Departamento implantou uma comarca judicial integrada por um juiz de direito, três juízes preparadores e um Juiz de Paz. Ainda em Sena Madureira instalou uma seção da Justiça Federal. Essas medidas beneficiaram mais os Departamentos do Alto Acre e Alto Purus, já que os processos judiciais do Alto Juruá eram enviados para Sena Madureira, via correios, de Manaus, e isso demandava três meses.

No ano de 1909, os autonomistas dos três Departamentos uniram-se e resolveram, através de um levante armado, "fazer a emancipação do Acre na marra". Antes, porém,

\footnotetext{
${ }^{62}$ CASTRO, José Plácido de. Relatório apresentado ao Exmo. Sr. Dr. Augusto Tavares de Lyra. D.D. Ministro da Justiça, por José Plácido de Castro, Prefeito Interino (1906 - 1907) In: Os anos do conflito. Rio Branco: Tribunal de Justiça do Estado do Acre, 200?, p. 7 - 9
} 
tentaram, enviando uma representação de cada Departamento, sensibilizar os integrantes do Parlamento brasileiro a votar a favor da elevação do Acre a Estado. No entanto, nada conseguiram.

Diante do fracasso desta tentativa e descontentes com os rumos da administração do Acre, os autonomistas do Alto Juruá, em 1910, depuseram as autoridades constituídas e governaram a região por cem dias.

Mesmo diante da resistência organizada, ruidosa e as vezes armada dos autonomistas do Acre, o governo federal, as elites nacionais e a maioria do Congresso Nacional consideravam que o Acre ainda não possuía as condições necessárias para “caminhar com as próprias pernas”.

A propósito, o Prefeito do Alto Acre, Gabino Besouro, em seu relatório de 1909, na contramão dos acontecimentos afirmava que

Em autonomia "immediata" do Território, de que tanto se fala na Capital Federal, ao ponto de preocupar também o meu espírito ao deixar o Rio de Janeiro, poucos aqui pensam. A maioria só deseja a autonomia quando o Governo Federal a tiver preparado, encaminhando a população, por meio de medidas e de uma educação convenientes, para melhor compreensão e exercício dos direitos políticos della decorrentes, o que, aliás, se faz indispensável $^{63}$

Para o governo federal, era necessário “domar a selva”, civilizá-la, para só então conceder a autonomia. A emancipação era, portanto, vista como uma concessão e não como um direito pelas forças políticas conservadoras, autoritárias e centralizadoras da República brasileira.

Em 1912, na gestão da Presidência do Marechal Hermes da Fonseca, o Acre passa por uma nova reforma administrativa que criou o Departamento do Alto Tarauacá, com sede na Vila Seabra, os cinco primeiros municípios do Acre (Purus, sede em Sena Madureira; Rio

\footnotetext{
${ }^{63}$ BESOURO, Gabino. Relatório apresentado ao Exmo. Sr. Ministro do Interior, Dr. Augusto Tavares de Lyra. Vila Rio Branco. Departamento do Alto Acre, 1909.
} 
Branco; Xapuri; Juruá; com sede em Cruzeiro do Sul e Tarauacá; com sede em Seabra), instituiu os conselhos municipais nos municípios acima mencionados, os quais eram compostos por pessoas indicadas pelo Presidente da República. Estes Conselhos, espécie de Câmara de Vereadores passaram a ter seus integrantes eleitos pelo voto popular em 1917 e instalou um Tribunal de Apelação em Cruzeiro do Sul.

No ano de 1917, o Acre passou por nova reforma judiciária, pois o Tribunal de Apelação de Cruzeiro do Sul, criado em 1912, fora desativado e o existente em Sena Madureira, instalado em 1908, transferido para Rio Branco. Nesse processo, os desembargadores de Sena Madureira foram colocados em disponibilidades, "afastados", porém, com direito aos vencimentos, e os de Cruzeiro do Sul transferidos para Rio Branco. Os Departamentos do Alto Juruá e Alto Tarauacá ficaram “sem justiça”.

Pelo Decreto de $n^{\mathrm{o}} 14.383$, de $1^{\mathrm{o}}$ de outubro de 1910, os Departamentos foram unificados e o Território do Acre passou a ser administrado por um governador geral nomeado pelo Presidente da República e Rio Branco, que ao longo desse processo foi a localidade "mais" beneficiada com os investimentos do poder público, tornou-se capital do Território Federal do Acre. Os municípios continuaram existindo, mas seus prefeitos passaram a ser nomeados pelo "Governador Delegado da União" e os integrantes das Câmaras municipais continuaram a ser eleitos pelo voto popular.

Por que tantas reformas? Como se explica esse vaivém de medidas administrativas do governo federal?

A perspectiva era desarticular o Movimento Autonomista, submeter os seringalistas ao poder da República ou "deixá-los à vontade”, transferindo seus desafetos, nos caso de juízes e desembargadores, para outras localidades, mesmo pagando o preço de toda uma localidade ficar ao "arrepio da lei". 
Em 1930, com a chegada de Getúlio Vargas ao poder e a reorganização das forças políticas em nível nacional, considerando-se a combinação de autoritarismo com modernização econômica que marcou a administração varguista, as câmaras municipais foram extintas e o Acre governado por interventores nomeados pelo Presidente Vargas.

Em 1934, em decorrência da Constituição brasileira instituída, os Prefeitos e vereadores dos municípios acreanos passaram a ser eleitos pelo voto popular e o governador continuava a ser nomeado pela Presidência da República.

Importante destacarmos que a Constituição brasileira de 1934 estabeleceu o voto secreto para prefeitos, vereadores, deputados e senadores e pela primeira vez a mulher passou a ter direito ao voto.

Em 1936, novas medidas foram implementadas. Desta vez, foi criado o Conselho Territorial, integrado por 7 membros nomeados pelo governo acreano e pelo Presidente da República. Este conselho serviria de base de cooperação e consultoria ao governador do Acre, bem como definiu-se que as câmaras seriam compostas por 7 vereadores, com mandato de 4 anos, e os prefeitos eleitos teriam, também, período igual de gestão.

Com o "Estado Novo", a expressão mais visível e cruel da ditadura Vargas, as Câmaras municipais foram extintas e os prefeitos voltaram a ser nomeados pelo governador do Território. A Justiça Federal existente na região também foi extinta.

Ainda no contexto da ditadura Varguista, dois novos municípios foram criados: Feijó e Brasília (atual Brasiléia). O primeiro desmembrado do município de Tarauacá e o segundo, derivado de Xapuri.

No de 1940, o governo federal dividiu o Acre em duas circunscrições jurídicas. A primeira abrangia as comarcas de Sena Madureira, Rio Branco e Xapuri e a segunda compreendia as comarcas de Cruzeiro do Sul e Seabra (atual Tarauacá). Em 1943, por 
Decreto-lei, Brasília passou-se a chamar-se Brasiléia (Brasil + Hiléia) e Seabra adotou a denominação de Tarauacá.

Na década de 1950, foram criadas mais duas comarcas judiciárias nas cidades de Feijó e Brasiléia. A primeira compreendia as comarcas de Rio Branco e Sena Madureira. A segunda, absorvia as comarcas de Xapuri e Brasiléia e a terceira estendia-se as Comarcas de Cruzeiro do Sul, Tarauacá e Feijó.

Pelo exposto anteriormente, percebe-se que a organização e a dinâmica da estrutura de poder no Acre não limitou-se a surperestrutura na medida que relaciona-se às peculiaridades geográficas da região, à economia extrativista implantada, às relações de trabalho entre o patrão-seringalista e seringueiro e aos interesses do grande capital pelo Acre, por um lado e as transformações que o Brasil vivenciou desde fins do século XIX até a primeira metade do século XX por outro, as quais, por sua vez, estão interligadas a conjuntura internacional marcada pelo imperialismo, as guerras mundiais e a expansão do nacionalismo, socialismo e comunismo.

E neste contexto, a perspectiva dos que “fizeram" a República era instituir a ordem política republicana em todo o território nacional.

Mas, como atingir essa meta no Acre? Para o governo federal seria através da subordinação da região, administrando-a diretamente, enquanto os Prefeitos Departamentais e governadores Territoriais oscilavam entre três posturas diferenciadas. Para uns seria através da força militar, outros acreditavam que seria com o uso da força da lei e alguns outros, que seria por meio da articulação política.

Com o Pós-Guerra e os novos ares da democracia no Brasil, a questão da autonomia acreana passou a ter como locus privilegiado o debate político tanto regionalmente quanto no Congresso Nacional e nos principais jornais locais e nacionais, numa conjuntura marcada pelo nacional desenvolvimentismo. 
E, como parte desse processo, em 1953, num discurso na Câmara Federal, José Guiomard dos Santos, ex-governador do Acre no período de 1946 - 50, canalizou para si a questão da autonomia acreana e organicamente instrumentalizará a partir de então os representantes das forças políticas locais para a concretização da emancipação política do Acre.

[. . . ] correndo os olhos pelo mundo afora sr. Presidente e Srs. Deputados, não se encontra muita cousa parecida com o estado a que se relegou o Território do Acre? Não chego a dizer que o Brasil seja opressor. . . o que existe é omissão, displicência e desconhecimento., Não se compreende as lutas para sua incorporação, se em seguida foi abandonado a própria sorte, destacando-se para ali, as vezes bisonhos emissários do poder central, desambientados, ou desocupados, verdadeiros ditadores mirins, sem o menor tirocínio administrativo, e nem ao menos vocação para a arte de governar $^{64}$ [Grifo nosso]

${ }^{64}$ SANTOS, José Guiomard dos. Cinqüentenário do Tratado de Petrópolis. Discurso proferido na sessão da Câmara Federal, de 17 de novembro de 1953, em nome da Maioria In: BEZERRA, Maria José (org.). DossiêAcervo: Guiomard Sanos (Acre) Elevação do Acre a Estado. Rio Branco: Globo, 1992, p. 47. 
1.1 - Os que mandavam

Os seringueiros viviam na "legião dos esquecidos" a mercê dos poderosos.

Pedro Martinello

As presenças de seringalistas e abastados comerciantes na paisagem social do Acre estão relacionadas ao processo de ocupação da região acreana a partir da segunda metade do século XIX.

Nesse sentido, é fundamental ressaltamos que, em nível mundial, notadamente nas economias capitalistas mais amadurecidas, vivia-se a fase imperialista do capitalismo. Era a era dos impérios, no dizer de Hobsbawn.

Assim sendo, como desdobramento desse processo, ocorreu a partilha afro-asiática e a disputa entre os E.U.A e Inglaterra pelo domínio da América Latina. E uma das práticas de política neocolonialista utilizada foi a busca por mercados consumidores de excedente de capital e da produção industrial européia e norte-americana e fornecedores de matériasprimas, e, dessa forma, o processo de acumulação e reprodução do capital ampliou-se consideravelmente.

Portanto,

com a emergência desse colonialismo, cujos traços característicos eram a conquista econômica e mesmo política dessas zonas estratégicas de colocação de bens de capital e da garantia do monopólio de suas matériasprimas acontece, praticamente, a partilha do mundo em colônias e a transformação do capitalismo em imperialismo, na acepção que the emprestou Lênin ${ }^{65}$

\footnotetext{
${ }^{65}$ MARTINELLO, Pedro. A batalha da borracha na Segunda Guerra Mundial e suas conseqüências para o vale amazônico. Rio Branco: UFAC, 1988. p. 25.
} 
Eric Hobsbawn caracteriza ainda melhor essa tendência da economia capitalista quando afirma que, "a partir da década de 1880, tornou-se universalmente popular entre as grandes potências o imperialismo - a divisão do mundo em colônias formais e em esferas de influência" $"$.

Importante ainda considerarmos que a prática usual do capitalismo consistia em investir capitais na indústria extrativa e bloquear o surgimento de qualquer indústria interna. Dessa maneira garantia, de um lado, o mercado para os seus produtos manufaturados e, do outro, o fornecimento das matérias-primas de que tanto careciam.

Portanto, o processo migratório para o Acre está diretamente relacionado aos interesses de sustentação e reprodução do capital monopolista que naquela fase do seu desenvolvimento necessitava de borracha, matéria-prima essencial à indústria de pneumáticos e derivados.

Outro aspecto a considerar é que o deslocamento populacional para o Acre ocorreu no momento em que o Nordeste, tradicional sustentáculo da economia brasileira desde o período colonial, estava em crise - provocada pelo surgimento de novos e mais poderosos concorrentes mundiais de seus produtos - acrescido do surgimento da liderança econômica da região Sudeste, composta por São Paulo, Minas Gerais e Rio de Janeiro, em decorrência da cultura do café. A conjunção destes fatores podemos incluir o fenômeno climático da seca.

Também é importante observarmos que no Brasil nas últimas décadas do século XIX ocorria a transição das relações escravistas de produção para a consolidação de relações assalariadas, embora não tenham sido descartadas formas não assalariadas como o colonato nas fazendas de café e a extração "compulsória” nos seringais do Acre.

66 HOBSBAWN, Eric. Da revolução industrial inglesa ao imperialismo. Rio de Janeiro: Forense/Universitária, 1978, p. 138. 
Por outro lado, no campo político vivia-se a passagem do "outono" da monarquia para o advento e consolidação do regime republicano frente às tensões e crises que marcaram os primeiros governos da República brasileira.

Com base no exposto, a partir da segunda metade do século XIX e princípio do século XX, o Acre tornou-se o alvo de uma verdadeira "corrida econômica", tendo os rios como vias de penetração.

A região acreana, nesse período passou a ser explorada por viajantes exploradores e cientistas que faziam o mapeamento da região, adentrando os rios Juruá e Purus e daí navegando por rios como o Acre, o Chandless, o Tarauacá e outros.

Notório destacarmos que a província do Amazonas, desde 1852, organizou expedições exploratórias ao Acre. Para Ferreira Reis, os exploradores que se dirigiam ao Acre cumpriram a seguinte rota:

[. . . ] para subir do Purus, partiam do Lugar da Barra e de Manacapuru, este, espécie de entreposto comercial, habitado pelos Muras, pacificados ao tempo de João Pereira Caldas, e ainda pesqueiro real famoso [. . .] para subir ao Juruá, partiam de Coari, de São Paulo de Oliveira, do Tefé principalmente de Tefé. No Juruá, adiantavam-se até dois meses de viagem, atingindo o rio Tarauacá, naquele, indo até o rio Mucuim e o rio Tapauá ${ }^{67}$.

Também em 1852, várias expedições oficiais foram organizadas em relação do Purus, por determinação da Província do Amazonas, dentre estas citamos a de João Rodrigues de Cametá (Rio Purus); Sarafim Salgado (revelador do Rio Acre no vale do Purus); Manuel Urbano da Encarnação (exploração do Rio Acre até o Rio Mucuim), chegando até o Rio Madeira.

${ }^{67}$ REIS, Arthur César. A Amazônia e a cobiça internacional. Rio de Janeiro: Civilização Brasileira, 1982. p. 
Para a exploração da região do Juruá, também foram organizadas expedições. Em 1852, Romão José de Oliveira subiu o Juruá até a foz do Rio Mineroá, procedendo a uma descrição detalhada dos povos indígenas que habitavam aquela localidade.

Entre as expedições realizadas, destaca-se a comandada por João da Cunha Correia, que, através de uma excursão, partiu do Tefé atingindo o rio Juruá-Mirim. Do rio Tarauacá, na viagem de regresso, chegou até o rio Envira, e deste até o Purus. Em 1866, esse explorador integrou a comitiva de William Chandless em sua viagem pelo Juruá.

Em relação as viagens científicas organizadas em direção aos rios Juruá e Purus, merece destaque a realizada por Willian Chandless, geógrafo inglês, da academia Royal Geographical Society, de Londres, que em 1864 chegou ao Purus até a localidade atualmente conhecida por rio Chandless. Em 1866, Chandless chegou até o rio Juruá a pretexto de proceder a uma verificação da existência de um liame aquático entre os rios Juruá e Purus. Nessa viagem vários apontamentos foram redigidos versando sobre os rios do Acre, na perspectiva de facilitar a penetração dos exploradores de borracha.

Fica evidente que o interesse da Europa pela Amazônia estava vinculado as riquezas potenciais que esta possuía, particularmente a borracha, inclusive, merece citarmos que vários viajantes dos séculos XV, XVI e XVII, em seus diários de viagem, fizeram menção "as estranhas bolas utilizadas pelos índios americanos que saltavam sempre que jogadas de encontro ao solo"68.

Interessante ainda observarmos que a cobiça européia pela Amazônia recrudesceu a partir da realização de alguns acontecimentos tais como: os estudos desenvolvidos pelo astrônomo francês Charles Maire de La Condamine, em 1736, da Academia de Paris, acerca da árvore seringueira, denominada posteriormente de "hevea brasiliens"; A descoberta do uso da borracha como "objeto apagador" por Joseph Priestley (1770), possibilitando que os ingleses inventassem, mais tarde, um tipo de solvente capaz de modificar a forma da borracha após sua coagulação, a descoberta do processo de vulcanização da borracha, por Charles Goodyear, em 1839, possibilitando que ela se tornasse resistente às mudanças de temperatura;

\footnotetext{
${ }^{68}$ SOUZA, Carlos Alberto Alves. História do Acre - Novos temas nova abordagem. Rio Branco: Carlos Alberto Alves de Souza, 2002. p. 77.
} 
e a invenção do pneu por Dunlop, em 1888, num contexto caracterizado pela crescente fabricação do automóvel e do uso da bicicleta.

Tendo os rios como "caminhos que andam"69 a penetração na região acreana foi se processando e os seringais foram sendo organizados às margens dos rios, junto aos barrancos, sendo os seus proprietários, os seringalistas, também denominados “coronéis de barranco".

Portanto, como parte deste processo ocupação, conquista, exploração e dominação da "selva amazônia", o rio mais do que a terra marcou a existência dos que ousaram vir para o Acre. Nas suas margens, a dialética da vida se manifestava numa sucessão de nascer, crescer, viver e morrer. "Eu nasci no Juruá". "Foi feliz no Envira". "Casei no Tarauacá".

A este respeito, frente a expressão que o comércio apresentava naquela localidade a Companhia Fluvial do Alto Amazonas iniciou a navegação do rio Juruá. Em 1877, a Província do Amazonas para instituir a ordem e a lei criou um distrito policial, com jurisdição em toda a extensão do rio e em 1879, transferiu funcionários da Fazenda para a região, no afã de regularizar a arrecadação de impostos considerando o lucrativo comércio desenvolvido na área.

No Juruá, no início do processo de exploração da borracha, tiveram destaque o Coronel Francisco F. de Carvalho, que em 1870 fundou o seringal Riozinho da Liberdade, e os Coronéis Antônio Petrolino Albuquerque, Miguel Fernandes e João Busson, os quais, em 1877, penetrando o rio Tarauacá, fundaram vários seringais. Em 1883, Antônio Marques de Menezes montou um seringal no rio Moa e os coronéis João Dourado e Balduino de Oliveira chegaram a ocupar as áreas de fronteira com o Peru.

É mister assinalar que este processo de ocupação das terras do Acre, com a formação dos seringais foi marcado pela violência em relação aos povos indígenas frente às "correrias" que se processaram e o conseqüente aprisionamento, desestruturação cultural e genocídio, emergindo destes contatos interétnicos o preconceito social em relação ao índio, o qual ainda é muito presente

${ }^{69}$ TOCANTINS, Leandro. O rio comanda a vida - uma interpretação da Amazônia. Rio de Janeiro: Companhia Editora Americana, 1972, p. 305. 
na região acreana, pois o nativo do Acre, na sua grande maioria, sacraliza a ascendência nordestina ou árabe e "esconde" ou abomina a indígena.

A instituição dos seringais foi se desenvolvendo a medida que o fluxo migratório para o Acre se tornava mais intenso.

Ao analisar o deslocamento da população nordestina para a Amazônia de uma forma geral, Pedro Martinello assinala que no último quartel do século XIX se atingiu "o percentual de 500 mil’. E, citando Roberto Santos, elenca alguns fatores que ressaltam a preferência pela Amazônia:

a) preconceito do trabalhador nordestino pela labuta dos cafezais, considerada tradicionalmente uma ocupação de escravos; [. . .] Amazônia, dava noção de liberdade;

b) As ilusões de enriquecimento rápido a que o boom da borracha expunha o nordestino, suficientes para superar os estímulos de maior salário ou remuneração do sul;

c) propaganda e arregimentação, realizada pelos prepostos de seringalistas do Pará e do Amazonas e do Amazonas em Fortaleza, Recife e Natal, atraindo os nordestinos diretamente para o trabalho nos seringais;

d) subsídios que os governos do Pará e Amazonas concediam ao transporte de imigrantes em vista dos programas de colonização agrícola mas que redundavam por favorecer, em última análise, a migração para mas zonas extratoras da borracha;

e) maior proximidade e facilidade do transporte de cabotagem até o porto de Belém em relação ao sul do país;

f) ruptura da resistência dos senhores de terras nordestinas à saída de homens, numa época em que as secas dizimavam as populações e acumulavam miséria, nos campos e refúgios nos núcleos urbanos ${ }^{70}$.

Demonstra ainda Martinello que Graham e Buarque de Holanda Filho, em suas análises acerca da migração nordestina para a Amazônia, apontam alguns fatores que coincidem com a visão de Roberto Santos. No entanto, esses privilegiam como as principais razões da migração a conjugação de três elementos básicos que são:

\footnotetext{
${ }^{70}$ SANTOS, Roberto Araújo de Oliveira. História econômica da Amazônia (1800-1920). São Paulo: TA Queiroz, 1980, p. 108. In: MARTINELLO, Pedro. A “batalha da borracha” na segunda guerra mundial e suas conseqüências para o vale amazônico. Rio Branco: UFAC, 1988, p. 38-39.
} 
1) Os promotores da migração, oriundos dos seringais estavam presentes, prontos para recrutar a massa de desempregados e refugiados que abundavam pelos postos de Fortaleza, Natal e Recife;

2) a psicologia, do sertanejo era mais favoravelmente mais atraída pela síndrome do El Dorado das áreas amazônicas. Fortunas deviam ser construídas lá, não no sul;

3) finalmente, a Amazônia estava mais perto e, a navegação mais fácil e freqüente dos postos do Nordeste a Belém do Pará do que para o sul ${ }^{71}$.

Importante ressaltarmos que, para esses migrantes, não havia a perspectiva de uma permanência definitiva. A emergência e improvisão que caracterizaram o seu processo de deslocamento nos permitem inferir acerca da anuência da preocupação de se fixar na região.

E como parte deste processo de ocupação, nos rios Juruá e Purus foram organizados os primeiros seringais.

Para viabilizar o estabelecimento dos primeiros seringais, muitas vezes, integrantes de expedições exploradoras se constituíam guias, indicando aos seringalistas quais as áreas que poderiam ser ocupadas por estes.

Em 1852, o seringalista Manoel Nicolau de Melo, vindo de Pernambuco, estabeleceu um seringal no Lago do Aiaperá, a conselho de Manoel Urbano, grande conhecedor do rio Purus.

E assim, a partir da segunda metade do século XIX, os seringais foram sendo organizados. Em 1869, o cearense de Oruburetama João Gabriel de Carvalho e Melo, acompanhado de outros cearenses, estabeleceu-se na área de Tanuaria. E em 1871, tendo Manoel Urbano como guia, o coronel Pereira Labre, aprofundando a penetração no rio Purus, fundou o povoado de Lábrea.

Anos depois (1877), adentrando ainda mais o Purus, o coronel João Gabriel chegou até Boca do Acre e, à margem direita do rio Purus, fundou um seringal na localidade atualmente conhecida como “Anafaz". E no ano de 1878, este, financiado pela Casa Aviadora E. J. Nunes

\footnotetext{
${ }^{71}$ MARTINELLO, Op. Cit. p. 39.
} 
da Silva e Cia., transportou um grupo de nordestinos para o corte da seringa às margens dos rios Acre e Iaco.

Num crescente, vários seringalistas foram ocupando o Acre. Em 1880, os Coronéis Alexandre Oliveira e Lima e Caetano Monteiro da Silva fundaram dois seringais no Alto Purus e o Coronel Hermínio Rodrigues Pessoa funda um seringal no rio Iaco; e em 1882, o cearense Neutel Maia fundou o sítio "Volta da Empresa", na margem esquerda do rio Acre, no qual instalou o seringal Empresa, local de origem da atual Rio Branco, capital do Estado do Acre.

Em 1890, o rio Xapuri foi explorado por José Felipe da Silva. Em 1892, o seringal Iracema foi organizado por Raimundo Vieira Lima e em 1894, João Damasceno Girão ocupou uma grande área no rio Acre fundando um seringal nas terras da atual cidade de Xapuri.

Mais especificamente no que se refere ao Juruá, desde de 1865, que William Chandless, em suas andanças naquela localidade, registrou as presenças de cortadores de seringa e coletores de salparrilha em 1870.

Considerando que a maioria do contingente populacional da migração dirigiu-se para o Acre e os altos rios, Martinello estabelece como razões dessa preferência

a) busca de recursos imediatos e temporários;

b) incidência abundante de seringa na região;

c) necessidade de novos espaços visando possibilitar a ocupação de todo o potencial disponível de mão de obra;

d) esgotamento parcial das árvores produtora do látex nas regiões dos baixos rios ${ }^{72}$.

Como resultante deste processo, Arthur Cesar Ferreira Reis assinala que, até 1870, vieram para a Amazônia 200.000 pessoas, das quais 70.000 estavam no Acre às vésperas de sua incorporação ao território nacional ${ }^{73}$.

\footnotetext{
${ }^{72}$ Ibid., p. 40.

${ }^{73}$ REIS, Arthur Cesar Ferreira. O seringal e o seringueiro. Rio de Janeiro: Serviço de Informação Agrícola. Documentário da vida rural. $\mathrm{N}^{\mathrm{0}} 5,1953$, p. 41.
} 
Portanto, a participação nordestina, notadamente cearense, foi considerável para a constituição do patrão-seringalista, embora também houvesse aqueles descendentes de sírios, libaneses, portugueses, espanhóis, porém, com ênfases maiores para os dois primeiros.

Mas quem era o patrão-seringalista e que perfil psicológico, social e político apresentava?

Os proprietários dos seringais do Acre eram, na sua maioria, homens rudes, - alguns sabiam "ferrar o nome" -, autoritários, e que no universo da "selva", do seringal, representavam o poder nas suas várias dimensões. Eram o patrão, juiz, conselheiro, compadre, protetor. Nos primeiros tempos de constituição do Acre estavam sempre em confronto direto com as autoridades jurídicas frente ao uso da violência e do arbítrio nas suas relações com o seringueiro e o índio.

No contexto do seringal, sua expressão de poder estava personificada na barracão.

Disciplinados por excelência, tem de mostrar-se a altura quantos problemas lhe surgem, principalmente a ordem que deve ser mantida nos barracões nos "fabricos", nas tarefas de todo o dia. Muitas vezes se mostra violento, indo mesmo a barbárie no trato com os seus homens. Seus métodos de ação por isso mesmo, lhe têm valido a acusação de desumano, explorador do sangue de seus jurisdicionados, senhor de escravos, barão feudal.

Ora, é preciso compreendê-lo no meio social de onde veio e em que vive. Lidando com homens, só homens, dominados pelas angústias do isolamento na floresta, não pode absolutamente, ser um tipo de salão, de gestos maneirosos, revelando educação aprimorada. O respeito que impõe, a direção que precisa dar aos negócios do seringal exige-lhe ação pronta, enérgica e explica a aspereza. Tem de ser dinâmico, rude, talvez tirânico. Qualquer fraqueza, qualquer indecisão pode levar a um desastre. O senhorio que exerce precisa ser mantido sem hesitações. Lança mão de recursos bárbaros, muitas vezes, para poder conter o desenfreio natural no ambiente duro, é verdade. Quando os fregueses ousam fazer-lhe exigências, que pretendem abandonar o trabalho, cometem falhas, empregam processos condenados na extração do látex, os meios de punição ou de correção que aplica são realmente violentos. Tortura-os, prendendo-os no tronco, como se fossem negros da época da escravidão. Se entende que sofreu uma desfeita que lhe macula a dignidade, pondo em jogo a própria honorabilidade, não treme na ordem para eliminar o ofensor. Age, assim, sem freios. Sua vontade é a lei. A autoridade do magistrado civil ou militar, que vive na sede da comarca e, pela distância e falta de elementos naturais, quase não pode chegar ao seringal para o policiamento moralizados e disciplinador êle a exerce em conseqüência, a seu modo, ignorando a dos 
outros, a autêntica, a legal, exerce-a de acôrdo com a concepção primária da vida, de moral, a que se habituou desde infância. Faz justiça como lhe parece deva ser feita. ${ }^{74}$. [Grifos nossos]

Embora no texto acima Ferreira Reis construa uma argumentação para justificar as arbitrariedades dos patrões-seringalistas no âmbito do seringal onde os "braços da lei, do Estado", não podiam alcançá-los, fica evidente a feição autoritária, conservadora e arbitrária que estes possuíam.

Numa pesquisa que coordenamos em 1997, através do Projeto "Seringueiros memória, história e identidade", como parte da disciplina "Metodologia da Pesquisa Histórica" e como coordenadora do Centro de Documentação e Informação Histórica da UFAC, tendo como pesquisadores os discentes do Curso de História diurno, coletamos vários depoimentos de nordestinos que vieram para o Acre, no período de 1900 a 1945, e os testemunhos que eles nos deram testificam a representação construída por Ferreira Reis. Vejamos o que nos conta o Sr. Cizinho Muniz:

Eu nasci no Ceará, em 1905, num lugar que se chamava Campo Grande, hoje se chama Guarapiava. Vim para o Acre e em 1913 fomos morar no seringal Taperipi, do coronel José Paulino. Eu não conto vantagem nenhuma dos altos rios. Eu vim para esta terra com 8 anos de idade [. . .] Depois que meu pai foi embora, em 1924, daí prá cá nunca mais eu vi ele. $\mathrm{Eu}$ fiquei me virando no mundo, me criando, sofri muita coisa feita por patrão, muita ladroagem, por exemplo, borracha que dava 86 quilos, na balança do patrão só dava 50 e eles só queriam ter razão, queriam ser bons, mas matavam por brincadeira. O cabra que tirava saldo eles mandavam matar, mataram muita gente lá nos altos rios. Eu rezo muito pai nosso prá Getúlio Vargas, foi ele que acabou com essa bandalheira, tanto com os cangaceiros do Ceará quanto com os ladrões aqui do Acre ${ }^{75}$. [Grifos nossos]

Na representação construída por este nordestino, vários aspectos se destacam quanto à relação social entre o patrão-seringalista e o seringueiro. A violência está presente de forma efetiva no

\footnotetext{
${ }^{74}$ REIS, Arthur César Ferreira. O seringal e o seringueiro. Rio de Janeiro: Ministério da Agricultura, 1953, p. 114.

${ }^{75}$ MUNIZ, Cizinho. depoimento.:Entrevista realizada pela equipe de pesquisadores do Projeto "seringueiro: memória, história e identidade. 1977.
} 
cotidiano do extrator de látex e o seringal é descrito como o espaço do conflito social, onde o maior desafio para o seringueiro é manter-se vivo seja pela forma exaustiva de trabalho, seja pelas enfermidades que poderia adquirir, seja pelo desentendimentos que poderia ter com o patrão.

A importância deste e de outros registros orais que temos trabalhado é a possibilidade de desconstruirmos o discurso da historiografia tradicional sobre o Acre que não "olha" o seringal como espaço da luta social. Este é geralmente visto apenas como uma unidade de produção em que a presença masculina era dominante. No entanto, embora os homens fossem maioria, a mulher também estava presente no seringal como extratora e não apenas na condição de doméstica, sobretudo no segundo surto da borracha, ocorrido no contexto da Segunda Guerra Mundial.

Nasci no Ceará, na cidade de Mocarapi em 1927, mudamos com toda a família para o Acre em 1944 [. . .] Vemos para o seringal já prá cortar seringa, meus irmãos já eram grandes, no mesmo ano que chegamos já fomos para o seringal. Meu pai botou um acreano prá ensinar os meus irmãos a cortar seringal. Nossa viagem foi de navio, gastamos uns dois dias de viagem do Ceará, até chegar em Belém. De lá para cá viemos de navio de novo até Boca do Acre, da Boca do Acre fomos para Sena Madureira e de Sena é que fomos pro Seringal Macauã. [. . .] meu pai abriu colocação botou os meninos para trabalhar e a gente ajudava a colher, só não fazia cortar. Em 6 meses eles aprenderam a cortar. O mais velho tinha 11 anos. Os nossos vizinhos moravam com duas, três horas de viagem, de uma colocação por outra [. . .] A gente ia colher, saia dez horas do dia, eles saíam quatro horas da manhã, chegavam uma ou duas horas da tarde, iam defumar, acabavam de defumar era seis horas da tarde, jantavam, dormiam, no outro dia iam trabalhar de novo ${ }^{76}$.

A narrativa de D. Geralda nos permite inferir acerca da saga do nordestino-seringueiro no Acre, a qual tinha início desde a viagem de deslocamento do Nordeste para o Acre. Sonhavam com o paraíso, mas o que experienciaram foi o inferno verde. A dualidade céu e inferno, luz e treva, marca o imaginário dos homens e mulheres que ousaram inventar o Acre.

E, ainda em relação ao papel da mulher no seringal merece destaque ressaltarmos o trabalho desenvolvido por Cristina Scheibe Wolff, "Mulheres da floresta - uma história. Alto Juruá, Acre

\footnotetext{
76 MORAIS, Geralda Alves. Depoimento: Entrevista realizada pelos pesquisadores do Projeto "seringueiro memória, história e identidade”. Rio Branco - Ac, 1997.
} 
(1890 - 1945)", quando esta com base na exaustiva pesquisa desenvolvida apresenta evidências incontestes quanto aos múltiplos papéis da mulher na constituição dos seringais e da sociedade ensejando relações de gênero que por sua complexidade vão além dos modelos formais estabelecidos, ao considerarmos que as relações sociais nesta parte da Amazônia Sul Ocidental são diretamente influenciadas pelas relações com a natureza, a cultura e a experiência vivida na floresta.

Importante destacarmos também que, contrariamente a posição defendida pelos historiadores tradicionais de viés positivista ou marxista, o seringal não era só o espaço do conflito, mas, também, das festas que ocorriam nas datas festivas religiosas ou cívicas ou quando da ocorrência dos casamentos, batizados, durante as desobrigas. E estas proporcionavam momentos de alegria, afetividade, bebedeiras, brigas, romances, separações. . O forró ao som da sanfona, banjo e pandeiro, se constituía o locus de manutenção da identidade do seringueiro, onde também era preservada sua memória coletiva. O lazer e a brincadeira proporcionava ao seringueiro o "fazer-se" social.

E muito embora, a maioria dos depoimentos retrate o patrão-seringalista como "mau", encontramos em nossas pesquisas várias testemunhas que o apresentam como "bom”. "Do seringal Macauã fomos pro Iaco, o meu tio morreu e o seringal foi arrendado pra outro patrão, aí fomos morar no Iaco. O patrão do Iaco era um homem chamado Hermes, era um bom patrão" ${ }^{77}$ [grifo nosso].

Além dos documentos oficiais ou da fonte oral, a literatura produzida acerca do Acre é pródiga no apresentar o mandonismo do patrão-seringalista e seu desrespeito às leis da República. Neste aspecto, merece menção, enquanto testemunho de época, a abordagem que Euclides da Cunha fez das condições de vida e trabalho do nordestino-seringueiro, nos primeiros tempos de constituição dos seringais acreanos.

[. . . o homem, ao penetrar as duas portas que levam ao paraíso diabólico dos seringais, abdica as melhores qualidades nativas e fulmina-se a si

${ }^{77}$ Ibid. 
próprio a vir com aquela ironia formidável. [. . .] De efeito, o seringueiro $e$ não designamos o patrão opulento, senão o freguês jungido, a gleba das "estradas", o seringueiro realiza uma tremenda anomalia: é o homem que trabalha para escravizar-se ${ }^{78}$.

$\mathrm{Na}$ categoria dos que mandavam, havia, também, os comerciantes, aqueles que aviavam os seringais trazendo mercadorias das praças de Belém e Manaus. Há registros de seringalistas que também foram abastados comerciantes, sendo, inclusive, proprietários de navios. E, neste campo, destacam-se os árabes (sírios e libaneses) e seus descendentes que marcaram a geografia social do Segundo Distrito (gênese da cidade de Rio Branco) com suas casas comerciais e outras urbes do interior do Estado do Acre como Xapuri, Brasiléia, Sena Madureira e Cruzeiro do Sul.

A este respeito merece menção a importância da imigração síria e libanesa para a Amazônia/Acre.

Os turcos ou a turcarada como tornaram-se impropriamente conhecidos nos primeiros tempos, foram assim designados devido o domínio da Turquia, até o final da primeira guerra mundial na região hoje ocupada pelos Estados da Síria e do Líbano.

E, a maioria dos que chegaram ao Acre, o fizeram na passagem do século XIX para o XX, na sua quase totalidade eram cristãos maronitas e chegando ao Acre tornaram-se regatões e/ou grandes comerciantes, ou, ainda, seringalistas.

Radicados em todo o Território do Acre, tiveram em Rio Branco grande destaque em função de praticamente monopolizarem o comércio, através de seus barracões de madeira edificados a margem do rio Acre.

A partir de meados da década de 1940, diante do processo falimentar do extrativismo da borracha, grande parte dessas Casas de Comércio transferiram suas instalações para o $1^{\circ}$ Distrito, área que concentra na atualidade as atividades comerciais, administrativas e financeiras de Rio Branco, Capital do Estado do Acre.

${ }^{78}$ CUNHA, Euclides. A margem da história. São Paulo: Martins Fontes, 1999. p. 35-36. 
Ainda na categoria dos comerciantes encontravam-se os regatões, que através dos rios abasteciam os seringais, e nesse processo conseguiram acumular capital suficiente para montar casas de comércio e/ou comprar ou arrendar seringais.

Aí começamos a lutar aquela vida de regatão, de princípio, nota-se que o pai deste era um homem, uma das maiores fortunas de Manaus, do Amazonas, mas ele queria tentar a vida só. Aí nos viemos e fizemos o caminho, foi devagar naufragamos diversas vezes, olha aqui, foi no naufrágio $\mathrm{e}$ trabalhamos em tudo. Carregava castanha, carregava tudo, nós não tínhamos residência, nós morávamos dentro do mato mesmo. E fomos lutando e com a ajuda a Deus fomos vencendo. Nós morávamos nos matos, que não tinha banheiro, privada, nem parede. Era assim. . . a noite a gente arriava e cada qual botava a sua rede, com o seu mosqueteiro e dormia, mas éramos felizes. [. . .] compramos uma baleeira, depois uma baleeira maior. [...] Depois começamos a fixar residência, nessa época já tínhamos gerente que viajavam que traziam. Nessa altura já tínhamos diversos seringais e os seringais nos abasteciam. Ele [seringal] nos dava o produto para carregar ${ }^{79}$.

Portanto, a intensificação do fluxo migratório para o Acre no período de 1870/1877 até 1912 e de 1939-40 até 1945 possibilitou a ocupação econômica do Acre e o desenvolvimento do extrativismo da borracha e como parte deste processo o fortalecimento político dos seringalistas e comerciantes, que, inclusive, através de suas organizações de classe - Associação dos Seringalistas, Associação Comercial do Acre e Associação Comercial de Cruzeiro do Sul intervieram na dinâmica econômica, política, social e cultural do Acre.

No entanto, essa posição de hegemonia dos seringalistas e comerciantes a nível local começou a decair a partir de 1946, em decorrência da crise da economia gomífera e estes seja através dos mecanismos estabelecidos pela política institucional, seja por meio de suas associações de classe buscaram implementar uma política de valorização da borracha como alternativa de superação da crise vigente.

Por outro lado, foi a partir da década de 1950 que o Movimento Autonomista ganhou novo impulso, na medida que a emancipação política da região passa a ser vista pelas forças políticas locais como um meio de tornar o Acre viável e o território da política se torna o

\footnotetext{
${ }^{79}$ ISPER, Alegria Abdala: depoimento: [18 de junho de 1996]. Entrevistadora: Maria José Bezerra. Rio Branco.
} 
espaço privilegiado para o debate emancipacionista, que através das várias organizações pró-autonomia - expandiu-se no Acre como um todo.

Dessa forma, para estes setores das "elites" locais, viabilizar o Acre implicava, necessariamente, formular e implantar um projeto político para a região, pois do ponto de vista econômico o quadro que se configurava era a falência da economia gomífera e posterior processo de transferência das terras do Acre para os empresários do Centro-Sul. 


\section{2 - E a borracha sustentava o Acre}

Não se lembram os viajores de autos e aviões quando em poucos minutos percorrem quilometros, que a borracha utilizada nos seus veículos foi extraída com mil sacrifícios, desde as doenças endêmicas à morte de muitos homens fortes, nem tampouco sabem a tragédia da vida nômade do seringueiro, que percorre estirões infindos em busca do látex, para gáudio das pessoas cultas, que pasmariam ante a miséria de um taperi ou fugiriam trêmulas ao enfrentar os inúmeros perigos da selva amazonense.

Jesuíno Ramos

O desenvolvimento da economia extrativista da borracha no Acre, segundo a literatura produzida a este respeito, particularmente a consistente pesquisa realizada por Pedro Martinello, em sua tese de doutorado, intitulada "A batalha da borracha" na Segunda Guerra Mundial e suas conseqüências para o vale Amazônico", pode ser compreendido em duas etapas, ciclos ou surtos.

No âmbito deste trabalho preferimos adotar o termo "surto" - neste caso, o primeiro surto da borracha teve início em fins do século XIX e terminou em 1912.

A este compreende a intensa migração nordestina para o Acre, a partir de 1870/1877, e a conseqüente formação dos primeiros seringais no Acre e o estabelecimento do sistema de aviamento.

Internamente destacamos que o aumento da produção da borracha nessa fase esteve intimamente relacionado com um maior influxo de mão-de-obra, tendo em vista que os métodos de produção, neste período, não sofreram nenhuma modificação nos seringais.

[. . .] se atentarmos, de fato, para os acréscimos periódicos da população amazônia e para a participação da produção brasileira de borracha no mercado mundial constataremos que esta relação é uma constante. $\mathrm{Na}$ verdade, em 1878, a produção mundial era exclusivamente brasileira. Em 1890 representava $90 \%$ da produção global. No período de 1900 a 1919, tal participação cai sucessivamente para $70 \%, 53 \%, 34 \%$ e $12 \%$. E os 
acréscimos populacionais praticamente refletem e acompanham esta participação ${ }^{80}$.

Nesse primeiro surto, os nordestinos vieram para o Acre em decorrência da ação efetiva dos agenciadores ligados aos proprietários das Casas Aviadoras, existentes em Belém e Manaus, ou aos seringalistas.

Do local de origem até os seringais, os nordestinos migrantes recebiam uma ajuda de custo para as suas despesas básicas pessoais que correspondiam às suas necessidades em termos de alimentação, roupas, transporte (passagem), cigarros, bebidas e outros objetos de uso. Tal fato configurava a formação de uma relação de trabalho, em que o trabalhador ficava previamente endividado, pois arcava com todas as despesas referentes a viagem, as quais eram debitadas em conta para posterior crédito do investidor.

Neste contexto, o nordestino migrante antes de se transformar em seringueiro e iniciar as suas atividades no seio da "selva" era definitivamente amarrado por dívida ao patrãoseringalista.

Dessa forma, a prisão por dívida torna-se a tônica dominante de uma estratégia que se destinava a "imobilizar a força de trabalho, vencer sua resistência pela aplicação impiedosa dos regulamentos, torná-la crescentemente dependente do patrão e perpetuar sua utilização e exploração na atividade extrativa" ${ }^{\prime 81}$.

Ao chegar ao seu destino - os seringais localizados nos rios Purus, Yaco, Acre, Juruá ou outros - o nordestino-migrante recebia os bens de consumo básicos para a sua alimentação, os utensílios de trabalho e os remédios para os primeiros meses. A partir desse momento, o nordestino-migrante transformava-se em seringueiro, um extrator, experiência essa nova, considerando a tradição agrícola que trazia.

${ }^{80}$ CARDOSO, Fernando Henrique MÜLLER, Geraldo. Amazônia, expansão do capitalismo. 2. ed. SP Brasiliense, 1978. p. 28.

${ }^{81}$ OLIVEIRA, Luiz Pinto de. O sertanejo, o brabo e o posseiro: cem anos de andanças da população acreana. Minas Gerais: UFMG, 1982 (Dissertação de Mestrado), p. 32. 
E o aviamento recebido ao chegar no seringal, acrescido das despesas de viagem e, ainda, considerando as práticas ardilosas do patrão-seringalista para aumentá-la, dificilmente este conseguia liquidá-la, pois nos primeiros anos de vivência no seringal era considerado um "brabo", ou seja:

[. . .] o nordestino novato nas operações de extrato do látex, chegado ao seringal, desconhece as técnicas de trabalho, os segredos da mata. É ainda um estranho ao meio físico e ao meio sócio-econômico. Ensina-se-lhe tudo. Necessariamente comete, nesses primeiros tempos, grandes imprudências, erra constantemente, reclama, ressente-se daquele mundo de novidades com que se defronta. Aos pouco, porém, se vai aclimando, perdendo as hesitações, afeiçoando-se às contingências locais, aprendendo o que deve aprender para poder permanecer no seringal e realizar os seus sonhos de enriquecimento $^{82}$.

Vencido o "estágio" inicial de "brabo", o seringueiro passava a "manso", tendo uma vida caracterizada pelo isolamento em que se desenvolvia o seu trabalho, pelas particularidades técnicas da atividade de extrator e pela exploração e violência a que estava submetido, ensejando o que Euclides da Cunha denominou de "a mais imperfeita organização de trabalho que engendrou o egoísmo humano" 83 , a partir do seu olhar positivista humanitário.

E o seringal, enquanto unidade de produção, apresentava uma divisão interna técnica e social do trabalho que extrapolava os dois pilares do sistema produtivo: patrão-seringalista e o seringueiro-extrator, qual seja gerente, guarda-livros, caixeiros, fiscais, noteiros, os quais relacionavam-se a autoridade, fiscalização, controle e repressão; os comboieiros faziam chegar as colocações os suprimentos que os seringueiros necessitavam, o mateiro, o toqueiro (chamado também de piqueiro) e o roceiro, os quais exerciam as atividades de descobrir a árvore-seringueira e preparar a área para o trabalho de extração do látex, incorporando, ainda outros trabalhadores vinculados à produção destinada à sobrevivência, quais sejam: caçadores, pescadores e trabalhadores do campo.

\footnotetext{
${ }^{82}$ REIS, Arthur César Ferreira. O seringal e o seringueiro. Rio de Janeiro: Ministério da Agricultura, 1953 , p. 116. Ministério da Agricultura, 1953, p. 116.

${ }^{83}$ CUNHA, Euclides da. A margem da história. Porto: Lello Brasileira, 1967, p. 51.
} 
Regulando o processo da produção, o sistema de aviamento articulava numa cadeia de dependência o seringueiro-extrator $\rightarrow$ patrão-seringalista $\rightarrow$ casas aviadoras de Belém e Manaus $\rightarrow$ casas exportadoras, as quais podiam funcionar como financiadoras de todo o processo de produção. E a dinâmica deste sistema produtivo funcionava vinculando as Casas Exportadoras (ligadas ao capital monopolista) e financiavam as casas aviadoras que se endividavam.

A crescente demanda mundial, impelida, particularmente, pelo desenvolvimento da indústria automobilística assegurava o aproveitamento de toda a borracha produzida no Acre. A economia do Acre vivia os seus tempos de prosperidade, de euforia, considerando que a região possuía uma grande reserva de borracha natural e tinha o domínio do mercado.

Assinala Pedro Martinello que, no período de 1880 a 1920, foi imensa a participação da borracha na economia brasileira.

Entre os anos de 1889 e 1897 a borracha responde em média, por 11,8\% da exportação total brasileira: entre 1898 e 1910, por 25,7\%; entre 1911 e 1913 , por $20 \%$; entre 1914 e 1918, por $12 \%$. Este significativo volume exportado é acompanhado, também, pelos excepcionais preços internacionais do produto. Em 1840, 45 libras por tonelada; em 1850, 41 libras; em 1860, 125 libras; em 1870, 182 libras; em 1905, 512 libras, preço que perdura até $1911^{84}$.

No entanto, essa fase de prosperidade estava com "os dias contados", pois o capital monopolista, para garantir maior produtividade e ampliar as margens de lucro, introduziu o plantio racional de seringueiras em suas colônias asiáticas.

Nesse processo, os ingleses foram os pioneiros na coleta e aclimatação das sementes e da experimentação da cultura da hévea de forma racional e sistemática nas plantations.

\footnotetext{
${ }^{84}$ MARTINELLO, Pedro. A "batalha da borracha" na segunda guerra mundial e suas conseqüências para o vale amazônico. Rio Branco: UFAC, 1988, p. 48-49.
} 
Numa ação coordenada e articulada envolvendo a Índia Office, o Jardim Botânico de Kew na Inglaterra e os Royal Botanic Gardens na Índia, o plano de coleta das sementes foi acionado.

As primeiras tentativas para pôr em prática o referido plano foram realizadas por $\mathrm{Mr}$. Cross, que enviara do Panamá e do Brasil, respectivamente, 100 mudas de castilhoa e 1.000 de hevea brasiliensis. Porém foi "Henry Wickham que realizou a coleta mais numerosa, seletiva, da cobiçada planta” ${ }^{85}$.

Roberto Santos, no seu trabalho sobre a economia da borracha, condena à luz do direito internacional a atitude de Wickham, mas o fato é que, graças às sementes levadas por esse aventureiro inglês, foi possível desenvolver o cultivo de seringueiras nas colônias inglesas do Oriente. E a produtividade destas, anos depois, colocou em xeque a hegemonia da produção brasileira.

Dessa forma, já em 1910 a produção do Oriente começava a tentar "desbancar" o Brasil e no ano de 1912, quando a produção da borracha natural atingiu o seu ponto máximo, teve início a queda do Brasil da posição de principal fornecedor dessa matéria-prima aos mercados mundiais. Em 1913, a borracha do Oriente já superava a produção amazônica enquanto a primeira apresentava o quantitativo de "48.000 toneladas, a segunda atingia o percentual de 39.560 toneladas" ${ }^{\prime 86}$. O monopólio brasileiro de produção da borracha estava vivendo os seus últimos dias. "Depois é a degringolada! A borracha explorada nas condições que vimos não resistirá à concorrência do produto oriental que em poucos anos a substituirá quase inteiramente nos mercados mundiais" ${ }^{97}$.

Portanto, a partir de 1920, a produção asiática passou a "reinar", "atingindo o percentual de 304.816 t. contra 30.790 dos seringais nativos. Em 1926, a produção brasileira

\footnotetext{
${ }^{85}$ SANTOS, Roberto Araújo de Oliveira. História Econômica da Amazônia (1800 - 1920). São Paulo: T. A. Queiroz, 1980, p. 49.

${ }^{86}$ Ibid. p. 51.

${ }^{87}$ PRADO, Jr. Caio. Formação econômica do Brasil. São Paulo: Brasiliense, 1972, p. 239.
} 
apresentava o índice de apenas 4,5\% do total. Em 1930, os seringais de cultivo produziram 800.808 t. e os seringais nativos, $17.137^{\prime, 88}$.

Segundo Martinello, a perda da supremacia brasileira foi motivada por vários fatores, entre os quais merecem menção os altos custos de extração do produto, o que impossibilitava competir com a produção do Oriente, a inexistência de pesquisas agronômicas financiadas pelo setor público, devido à falta de visão empresarial dos brasileiros ligados ao comércio da goma elástica, a carência de mão-deobra barata e da região, a insuficiência de capital financeiro aliado à distância e às condições naturais adversas da região. E deste, ressalta-se a ausência de progresso técnico no extrativismo pois o sistema arcaico empregado na extração do látex conduzia a baixa produtividade do trabalho e conseqüente elevação dos custos de produção.

Outro aspecto a destacar é que os interesses presentes na produção da borracha decorriam de setores absolutamente alheios às necessidades da população, na medida que estava vinculado ao desenvolvimento da indústria automobilística, que nada tinha a ver com as reais necessidades da Amazônia.

A crise da borracha agudizou-se com a queda dos preços a partir de 1914, pois as demandas passaram a ser menores que os estoques colocados à disposição dos países consumidores. Frente à superprodução, caíram os preços de exportação, baixa que permaneceu após a Primeira Guerra Mundial, em decorrência da incapacidade de absorção do mercado mundial e da "desorganização do transporte". "De 206 libras por tonelada em 1914, a borracha caiu para 174 libras por tonelada em 1918 e para 172 em 1920-21"89.

Como desdobramento do quadro vigente, a quebradeira teve início nas praças de Belém e Manaus, repercutindo nas finanças públicas. Para superá-la, várias tentativas foram feitas, tais como a organização da Liga dos Aviadores, convênio efetuado para captar recursos

\footnotetext{
${ }^{88}$ SILVA, Adalberto Ferreira da. Raízes da ocupação recente do Acre. Minas Gerais: UFMG, 1982 (Dissertação de Mestrado), p. 35.

${ }^{89}$ MARTINELLO, Op. Cit., p. 54.
} 
no exterior, Plano Pedro Toledo de apoio do governo federal pela defesa da borracha, as quais não surtiram efeito e a crise permaneceu inexorável.

Diante desse contexto, as "ondas migratórias" de nordestinos tiveram que fazer o “caminho de volta" e os que não conseguiram retornar aos seus locais de origem, dirigiram-se para as capitais de Belém, Manaus e Rio Branco que “incharam”.

Para o Acre sobreviver à crise, o que fazer? A perspectiva que se configurou foi o surgimento de colônias agrícolas no entorno de Rio Branco para melhorar o abastecimento desta, a exploração da castanha, das peles e couros, de plantas odoníferas, entre outras atividades de pequenas monta.

No entanto, como a crise se alastrava cada vez mais, provocada pelo excesso da produção de borracha do Oriente, gerando o aviltamento dos preços, os produtores criaram o Plano Stevenson, que perdurou até 1928. Com o seu término, estabeleceu-se uma fase de liberdade de comércio até 1933. Porém, nova crise surgiu no horizonte, gerando o colapso do mercado, pois as empresas asiáticas responsáveis pelas plantations não conseguiam mais lucrar e os dividendos que emitiam deixaram de ser pagos, o que as levou a sofrer brusca queda na bolsa de Londres. Como culminância desse contexto, a partir de 1930, a borracha chegou a atingir os menores preços vistos até então.

Considerando a situação calamitosa vivenciada, foi criada a International Rubber Regulation Agreement (1934 - 44), que passou a controlar o mercado, conseguindo uma certa estabilidade de preços, porém não conseguiu anular as flutuações.

Enquanto isto, no âmbito externo, o mundo se preparava para um novo conflito mundial. O nazifascismo em ascensão com sua política imperialista, ameaçava a paz mundial e a integridade dos países europeus. Por outro lado, os E.U.A e a Alemanha, em franca ascendência econômica, buscam "fincar suas raízes” na América Latina. 
O Brasil varguista do "Estado Novo" com a sua mal disfarçada simpatia pela Alemanha e a ideologia do nacional-socialismo, com a eclosão da Segunda Guerra Mundial, irá desencadear, por pressão norte-americana, a batalha da borracha.

Importante considerar que, frente à proximidade comercial e industrial bélica entre Brasil e Alemanha, os E. U. A, no início dos anos 40 do século XX, desencadeou uma ofensiva ideológica fundamentada nos princípios da política da "Boa Vizinhança" e do "Panamericanismo", o que implicou uma tomada de posição do governo brasileiro próAmericana. Nesse sentido, cabia ao Brasil integrar-se ao esforço de guerra, fornecendo matéria-prima a indústria bélica americana e manter a "qualquer custo" a ordem interna para evitar alterações nos compromissos políticos e econômicos assumidos com os E.U.A.

E, sob os auspícios do Birô Inter-americano, chefiado por Nelson Rockefeller, e financiado por grandes empresas como a General Eletric, Standard Oil, Metro Goldwin Mayer, Light and Power Co., The National City Bank of New York, além do apoio “escancarado" da embaixada americana, operacionalizou-se via imprensa, rádio e sobretudo o cinema, a ofensiva ideológica e cultural norte-americana, que consumiu milhões de dólares.

A III Conferência de Chanceleres na qual Oswaldo Aranha fez um discurso inflamado defendendo a integração de toda a América e a invasão japonesa da Malásia, Borneo e áreas próximas e depois Pearl Harbour gerando a crise de suprimentos de matéria-prima para a Guerra, foi o "tiro da misericórdia" para que o governo brasileiro tomasse uma posição próamericana e países aliados.

Tendo a borracha como o "motor da guerra", o Estado brasileiro viabilizou o deslocamento de mão-de-obra nordestina para o Acre, dando início à saga do "arigó"90.

Portanto, o segundo surto da borracha realizou-se num contexto de mobilização nacional, considerando-se que em toda a região amazônica, no início da década de 1940, “o

\footnotetext{
${ }^{90}$ Arigó expressão que designava o nordestino quando este chegava ao Acre.
} 
número de seringueiros não ultrapassava 34.000 extratores, com uma produção média anual de 16.000 a 18.000 t de borracha",91.

E com a guerra, a necessidade de borracha era premente, e aumentar a produção anual para 45 mil toneladas em 1942, 60 mil em 1943 e 100 mil t em 1944 e nesse sentido urgia no mínimo quintuplicar o número de extratores.

Frente a essa questão emergencial, produzir borracha para a guerra, a Rubber Reserve Company numa ação consorciada com autoridades brasileiras, ligadas ao setor de imigração vinha unindo esforço no sentido de aumentar e mão de obra para atender as exigências da indústria bélica americana e aliada. Cogitou-se, inclusive, de importar mão de obra de outros países como Porto Rico.

Nessa direção, a RDC e o Departamento Nacional de Imigração assinam um convênio, através do qual cabia à primeira o financiamento da operação e à segunda a supervisão do processo de imigração de mão-de-obra para a Amazônia.

As primeiras levas de nordestinos chegaram à Amazônia em 1942 e eram constituídas de flagelados, sobretudo cearenses, homens do sertão, do agreste e das caatingas, que, escorraçados pela estiagem e já no limite de suas forças e da própria sobrevivência, deslocavam-se com a família para a capital Fortaleza, no intuito de emigrar. Diferentemente da anterior, esta foi uma migração familiar impulsionada pelo desejo do nordestino de encontrar uma terra para viver, pois a seca não lhe dava outra opção.

No entanto, o que os esperava no seringal causava perplexidade e desencanto.

Quando eu cheguei aqui foi que vi o que tinha feito, mas arrependimento tarde não resolve nada. Aqui o seringal Bela União. . . esse que eu vim, era ruim demais. As minhas estradas era muito ruins de leite. . o leite era muito pouco, precisava muitos e muitos dias para fazer um princípio de dez quilos. Quando cheguei no barracão, que via pobreza em que encontrava aquele barracão e aquele patrão, aí eu fiquei triste. Fiquei triste, mas como eu tinha muita saúde, enfrentei. Enfrentei pra ver se. . . se vencia. Venci mas com muita dificuldade. No barracão, no barracão de madeira, a cobertura era de palha, só tava os talos em cima. O seringueiro, aquele seringueiro antigo que tinha lá, lá no seringal, a referência que ele me dava do patrão era a pior

${ }^{91}$ MARTINELLO, Pedro. Op. Cit. p. 209. 
possível. E aquilo tudo que eu escutava ainda ficava mais triste e contrariado. Mas nunca falei nada contra não, que não ia adiantar, já tava no fogo, já tava tudo perdido. ${ }^{92}$

É importante ressaltarmos que, se de um lado deslocar a população disponível no Nordeste para a Amazônia fosse a solução para aumentar a produção de borracha, havia problemas quanto à locomoção e colocação desta.

Para solucionar esses impasses iniciais, o governo brasileiro instituiu duas medidas: “concessão de crédito para 4.000 (quatro mil) passagens nos navios do Lloyd e do SNAPP em favor dos imigrantes e um crédito de 7.736.190\$000 para a localização de trabalhadores no Vale Amazônico"93.

No entanto, os mais agudos problemas que precisavam ser enfrentados referiam-se a transporte e alojamento dos migrantes frente ao fato de que o SNAPP não garantia a transferência da mão-de-obra do Nordeste para os seringais do Acre, o governo brasileiro pensou em fretar navios, substituir algumas linhas do SNAPP pelo Lloyd e até construir "navios" de menor calado tipo "chatinhas".

Quanto aos alojamentos existentes, devido às suas precárias condições, não atendiam as grandes demandas da imigração. Assim, fazia-se necessário construir hospedarias em tempo recorde nos locais de passagem dos migrantes, tendo sido construídas algumas em Fortaleza e Belém, principais pontos da viagem dos nordestinos para a Amazônia.

Outro aspecto a considerar era que, embora as passagens do Llody e do SNAPP fossem gratuitas, o migrante nordestino endividava-se com gastos nos albergues de Fortaleza, Belém, Manaus e Boca Acre, entre outros pontos de baldeação e com outras despesas feitas durante o trajeto do Nordeste para a Amazônia. Então, por sugestão do CIC (Conselho de

\footnotetext{
92 SOUZA, José Paiva de: depoimento [1997]: Entrevista realizada pela equipe do Projeto Seringueiro memória, história e identidade. Rio Branco.

${ }^{93}$ Diário Oficial da República, de 25.07.1942. no 172 p. 11. 657 In: MARINELLO, Pedro. “A batalha da borracha na segunda guerra mundial” e suas conseqüências para o Vale Amazônico. Rio Branco: UFAC, 1988, p. 212.
} 
Imigração e Colonização), o DNI (Departamento Nacional de Imigração) estabeleceu um plano de assistência com recursos daquele Conselho.

Outra preocupação do DNI foi a questão das relações de trabalho nos seringais, na medida que almejava conseguir um maior controle sobre as relações empregador-empregado, sobretudo frente às denúncias de "compra de homens" do passado. Nessa direção, foi elaborado um contrato de trabalho, no qual se fazia referência a horas de trabalho, direito do seringueiro comprar fora do barracão do patrão, supressão de multas aos seringueiros pela danificação de árvores, dentre os itens mais relevantes.

Como as medidas até então implementadas não atendiam as expectativas das autoridades americanas quanto a agilizar o novo surto de borracha, foi criado o Serviço de Encaminhamento de Trabalhadores para a Amazônia, com a finalidade precípua de recrutar e transportar os nordestinos para a Amazônia.

Posteriormente, criou-se a CAETA (Comissão Administrativa de Encaminhamento de Trabalhadores para a Amazônia, que configurava as funções do SEMTA e da SAVA, demandando um novo convênio entre a Comissão de Controle dos Acordos de Washington (CCAW) e a Rubber Development Corporation, substituta da RRC.

Merece menção frisarmos que, diferentemente das primeiras levas de migrantes da "batalha da borracha" que vieram para a Amazônia a partir de 1943, os migrantes aliciados e recrutados pelo SEMTA eram provenientes dos mais diversos "pontos do Brasil, inclusive de centros urbanos, sendo formados, em sua maioria, de homens solteiros ou separados de suas famílias, muitos deles desempregados seduzidos pela oportunidade de conhecer, à custa do governo, terras e paisagens distantes" ${ }^{94}$.

${ }^{94}$ BENCHIMOL, Samuel. A Amazônia: um pouco antes e além depois. Manaus: Umberto Calderaro, 1977. p. 376. 
Em relação a esse caráter diversificado da segunda leva de migrantes da "batalha da borracha", é interessante verificarmos

o que a Amazônia, naquela oportunidade viu, constituindo a maioria das levas de soldados da borracha que aqui chegavam, não foi a fina flor dos sertões, nada disso, e sim a lama do asfalto, o rebotalho das grandes cidades, egressos de presídios, inclusive, e que aqui chegados, roubando e matando, saqueando e ferindo, usando de todos os processos de violência, iniciaram uma etapa de terror e crime agravando seriamente os hábitos pacatos da população. O que a Amazônia viu, salvo pequenas e honrosas exceções, foi o malandro dos morros cariocas, foi o sangrador das caatingas, foi o assassino que cumprira pena em Fernando de Noronha ou na Ilha das Flores, enfim, o lodo das ruas, a escória social brasileira ${ }^{95}$.

Tal fato demonstra que também a "batalha da borracha" serviu de "válvula de escape" para as tensões sociais existentes nas cidades pelos "excluídos” ou "perigosos", os quais puderam ser compulsoriamente alistados no "exército da borracha" ou por certas organizações policiais das regiões Norte e Centro-Sul do país. Era um meio de o Estado se livrar dos indesejáveis.

Nas levas seguintes de "soldados da borracha", a preferência passou a ser por nordestinos recrutados nas zonas atingidas pelas secas do Nordeste, acompanhados de suas famílias, evitando-se a experiência malograda do SEMTA descrita acima.

Portanto, o flagelo das secas, o desejo de aventura, mas, sobretudo, a perspectiva de que ser "soldado da borracha" era um meio seguro de não ser convocado para integrar a Força Expedicionária Brasileira que lutava na Itália foram os fatores que contribuíram para aliciar e deslocar para a Amazônia mão-de-obra para a produção da borracha. Ou a Amazônia ou a guerra.

Um argumento de caráter ideológico bem presente no imaginário dos ex-soldados da borracha que entrevistamos como parte do projeto "seringueiro - memória, história e identidade" é o de que aquele que vinha para a Amazônia estava cumprindo um dever

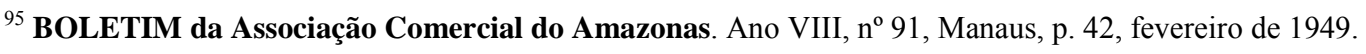


patriótico, ajudando o Brasil e os países aliados a combater o "inimigo", a "Alemanha", o “nazismo".

O cabra passa trinta anos dentro do seringal, nóis cheguemos no tempo da guerra, pois vivemo contratado pela companhia, negócio de guerra, e quando no fim o sujeito vence e ainda fica sem nada. Você veja que hoje só vale quem não fez nada, quem trabalha nada tem. Repara, quem botou o Brasil prá frente? Foi nóis que butemo o Brasil prá frente. . . Trabalhemo, vemo guerra, todas essas coisas fumo nóis. Demo nome a diversos presidente que hoje tão educado. Foi nós. Purque se num fosse nóis tê assumido responsabilidade eles também tinha entrado no ferro. Então eles não enxergam nada disso ${ }^{96}$.

Importante considerarmos que esse argumento foi utilizado mais tarde para reivindicar uma aposentadoria de dois salários mínimos do INSS para os ex-soldados da borracha, estendida às viúvas ou companheiras e aos filhos menores de 21 anos. Não é demais destacarmos que algumas mulheres já receberam esse benefício porque vieram do Nordeste para cortar seringa na Amazônia na época de guerra. A narrativa de D. Iracema explicita as condições de vida e trabalho nos seringais.

Trabalhei no seringal desde criança, quando os meus pais vieram da Paraíba para cá, pro Acre, na época da guerra. Eu tinha dez anos de idade quando comecei a cortar seringa. Eu levantava duas horas da madrugada. [. . .] Eu fiquei moça conheci o meu marido [. . .] Meu marido cortava uma estrada e eu outra. Ele ia na frente cortava a estrada dele, eu ficava cuidando da casa, Depois eu ia cortar minha estrada e tinha dia que eu cortava mais do que ele. Minha vida era muito dura, eu tinha que cortar seringa, eu tinha que fazer tudo em casa, cuidar dos meninos, lavar roupa, fazer comida, tudo e de noite ainda tinha que servir o marido[. . . $]^{97}$.

Em relação às condições de trabalho, é importante assinalarmos que a exploração permanecia embora sob a vigência do contrato-padrão de trabalho pois embora o seringueiro pudesse cultivar um hectare de terra, caçar e vender peles de animais; de toda a borracha produzida pelo seringueiro ser-lhe-ia creditado um valor de $60 \%$ sobre o preço oficial nas

\footnotetext{
${ }^{96}$ ALBUQUERQUE, Iracema Rodrigues de: depoimento [1997]: Entrevista realizada pela equipe do Projeto "Seringueiro - memória, história e identidade. Rio Branco.

${ }^{97}$ GONZAGA, Luiz. Depoimento. Entrevista realizada pela equipe do Projeto "Seringueiro - memória, história e identidade. Rio Branco, 1997.
} 
praças de Belém e Manaus, não se computando qualquer despesa ou frete, seguro ou imposto. Na prática estes itens era um "conto do vigário", um "canto de sereia”, pois o extrator tinha que entregar toda a borracha produzida para o patrão-seringalista e ela só podia ser exportada devidamente marcada pelo barracão ou pelo posto que o proprietário do seringal determinasse.

Por outro lado, a Rubber Development Corporation e a SAVA substituíam o comércio importador e exportador, pois o Banco de Crédito da Borracha S/A tinha como função receber, classificar, consignar obrigatoriamente o produto e a exportação de borracha.

No início de 1945, todos os fronts de guerra ainda estavam em plena atividade e a demanda por produtos derivados da borracha era enorme, especialmente pneus para veículos pesados. Por outro lado, o aumento do número de fábricas para manufaturas de pneus, por exigência do governo dos E.U.A., gerou uma necessidade crescente de borracha sintética para atender as demandas destas.

No entanto, o restabelecimento das zonas produtores de borracha do Extremo Oriente, implicou numa retração da demanda da borracha da América do Sul, fazendo com que as despesas do governo dos E.U.A para o fomento da produção da borracha na América Latina fossem reduzidos, permanecendo as aquisições por força dos acordos estabelecidos até que estes expirassem os seus prazos, contando os E. U. A com outros fornecedores de borracha como a Libéria, na África e o Ceilão.

A partir dessa fase, a postura dos americanos será a de desengajamento e retirada da Amazônia, atitude esta "vislumbrada desde 1944, quando o governo americano, em troca de um abono de US\$ $0.33,3$ no preço de compra, negava-se a prestar qualquer assistência financeira aos diversos projetos do programa da borracha na Amazônia e Mato Grosso, transferindo esse encargo ao governo brasileiro" ${ }^{, 98}$.

\footnotetext{
${ }^{98}$ MARTINELLO, Op. Cit., p. 293.
} 
Assinala Martinello que pós-guerra, particularmente após outubro de 1945, a RDC, expressão máxima da intervenção americana na produção da borracha na Amazônia, adotou uma política de desmobilização e como parte desta cedeu ao governo brasileiro, por meio do Banco de Crédito da Borracha, todo o acervo de seus bens, instrumental e maquinaria trazidos para a Amazônia. A retirada final dos americanos da Amazônia completou-se oficialmente em junho de 1946, quando os escritórios da RDC de Manaus, Rio de Janeiro e Belém (setembro do mesmo ano) foram fechados, quando do término dos Acordos de Washington ${ }^{99}$.

Com a retirada dos americanos da Amazônia, a economia do Acre entra em crise, trazendo como reflexo a desativação dos seringais, e o "seringueiro-soldado" é deixado ao "Deus-dará".

Esse quadro de penúria vivido pelos seringueiros é descrito de forma pungente pelo governador do Território do Acre, José Guiomard dos Santos.

[. . .] muitos dos males diagnosticados são produtos da última imigração, conhecida por "Batalha da Borracha", que trouxe para o Território uma regular parcela de problemas a adicionar ao total, não pequeno dos que já existiam aqui.

É que a imigração foi a mais desprovida que se possa imaginar. Sem prévia ambientação do indivíduo ao meio que vinha viver; sem imunização perfeita contra os males e endemias comuns e previstas no percurso da jornada a empreender; atirados em horrível promiscuidade a bordo dos gaiolas; subnutridos; sem higiene; sem defesa orgânica e material esses patrícios marcharam para o front ascenados por uma bandeira de delícias, de riquezas fáceis que jamais alcançariam. Agora, os chamados "soldados da Borracha", constituem uma verdadeira coluna de fracassados cujo processo de reabilitação está se processando, mas que ainda demanda tempo e recursos. Este governo já se acha em contato com a Comissão de Amparo aos Retornados da Campanha da Borracha, e num trabalho de colaboração está encaminhando a solução deste problema nacional ${ }^{100}$.

Esse espetáculo da miséria encenado pelos "soldados da borracha" tem como cenário a cidade de Rio Branco, para onde se dirigiram quando deixaram os seringais, pois os que não

\footnotetext{
99 Ibid., p. 295

${ }^{100}$ SANTOS, José Guiomard dos. Relatório Apresentado ao Exmo. Sr. General Eurico Gaspar Dutra, D. D. Presidente da República, pelo Major José Guiomard dos Santos, Governador Delegado da União no Território Federal do Acre, referente às atividades da administração acreana no exercício de 1946. Rio Branco, 1946. p. 11-12.
} 
conseguiram retornar para seus Estados de origem ficaram à mercê da própria sorte em Rio Branco - "abandonados, rôtos, doentes, com os filhos empanzinados"101.

A crise social vigente exigirá que o governo do Território empreenda uma política agrícola, não só para "dar trabalho" aos "arigós” desempregados que perambulavam pelas ruas de Rio Branco em busca da sobrevivência, como também busque superar a dependência do Acre ao mercado, seja às praças de Belém e Manaus, onde ficavam as casas aviadoras que abasteciam as casas de comércio localizadas no $2^{\circ}$ Distrito, seja aos produtores do Sul do Brasil.

Urgia empreender uma política econômica para a região.

tive oportunidade de despertar a atenção do povo para a incoerência que perdura de vivermos na dependência dos produtores do Sul, para ter a banha, o arroz, o feijão, o café, o açúcar e tantos outros produtos de primeira necessidade, que podem ser produzidos aqui, em larga escala, em quantidade suficiente para as nossas próprias necessidades, sem que esses gêneros necessitem de percorrer muitas centenas de milhas para abastecerem nosso mercado! ${ }^{102}$

Viabilizar o Acre significará para a política interna do governo territorial instituir um plano de desenvolvimento agrícola e nessa direção, Guiomard Santos, através do Departamento de Produção, criou as colônias agrícola desapropriando as terras do seringal Empresa.

Esse plano, em suas linhas gerais, estabelecia:

a) cessão de terras aos seringueiros que se retiravam dos seringais, alguns até com rumo ao Nordeste e que aqui ficaram pela facilidade na obtenção de sua pequena propriedade - graças ao loteamento do antigo seringal Empreza; b) auxílio, inclusive com gêneros alimentícios nos primeiros meses, na fase de instalação, aos colonos mais necessitados; c) revenda de material agrário, pelo custo e para pagamento mesmo com os produtos agrícolas; d) assistência social com a instalação de escolas rurais nas colônias, não somente para o ensino primário dos menores, como também para a alfabetização dos colonos adultos; e) abertura de pequenas estradas rurais,

\footnotetext{
${ }^{101}$ SANTOS, José Guiomard dos. Carta ao velho Cintra. Rio Branco: Território Federal.

${ }^{102}$ Ibid., p. 13.
} 
facilitando o transporte para o mercado local, embora que esse transporte, reconhecemos, seja ainda bem precário; f) assistência médica, quinzenalmente e com enfermagem diária, pois em cada colônia foi destacado um enfermeiro residente, com ambulância; g) cessão de mudas e sementes gratuitamente, pela Estação Experimental agrícola; h) instalação de usinas de beneficiamento de produtos agrícolas, com prédio construído em alvenaria, coberto de telhas, compreendendo o conjunto as seguintes máquinas: motor a óleo ou máquina a vapor para fornecer força às demais máquinas, funcionando como centro do conjunto; máquinas de descascar arroz, máquina de despolpar café; máquina de debulhar milho; engenho para cana de açúcar, com a respectiva bateria de taxos; caetetú, prensas e fornos para o preparo de farinha e demais utensílios, tais como: bacias, depósito para massa, formas para rapadura, etc., sendo que alguns desses conjuntos já estão funcionando com iluminação elétrica, o que facilita o trabalho noturno, dando assim maior rendimento ${ }^{103}$.

Esse plano visava não apenas o assentamento dos "retornados da Batalha da

Borracha", mas, com o regime da pequena propriedade rural, a perspectiva almejada era fixar

o homem à terra e despertar nele o interesse em ser proprietário - formar um patrimônio para si e os familiares, assegurando um futuro diferente daquele vivido até então pelos seringueiros.

Para ter o título definitivo de posse das terras agrícolas, o colono deveria atender os seguintes requisitos:

a) Residir com sua família no lote, ali trabalhando e dirigindo os trabalhos agrícolas e pastoris; b) não vender, hipotecar, trocar, transferir ou alienar de qualquer modo o lote, casa e benfeitorias, sem prévia autorização da administração e sem que liquide antes o débito contraído com o governo por quaisquer fornecimentos; c) conservar no mínimo a quarta parte da área total do lote em mata ou proceder ao reflorestamento na mesma proporção, se já houver sido devastada; d) pagar C $\$ 10,00$ por hectare ou fração como preço do lote, ao receber o título definitivo; e) ocupar, no mínimo, dois hectares com seringueiras de plantio; f) apresentar, no fim do primeiro ano de ocupação, pelo menos, três hectares com culturas diversas, sem o que lhe será cassado o título provisório ${ }^{104}$.

Paralelamente à política de incremento das atividades agrícolas, que não se limitou a criação de colônias, mas, também ao desenvolvimento da criação de aves, suínos, bovinos, búfalos, agricultura e piscicultura, o governo tem como desafio superar as distâncias do Acre

\footnotetext{
${ }^{103}$ MAGAlHÃES, Valério Caldas de. Relatório do Departamento de Produção. Rio Branco, 1949. p. 19-20.

${ }^{104}$ GUERRA, 1955, Op. cit. p. 131
} 
de outros centros e, para concretizar esse ideal, criou os campos de pouso em todos os municípios do Acre e construiu o Aeroporto Salgado Filho e a Estação de Passageiros, em Rio Branco, tornando o avião transporte oficial do Território.

Merece destaque assinalarmos que a precariedade das condições de vida dos seringueiros contribuía para que no Acre as incidências da lepra, da tuberculose e da loucura fossem significativas.

Inventar um Acre saudável era não só construir espaços destinados ao tratamento dos acometidos por essas moléstias, mas, também, importar profissionais da área da saúde, que nos postos médicos, hospitais e casas de saúde pudessem atender as demandas dos acreanos.

Para a concretização da meta acima

[. . .] foram melhoradas as instalações hospitalares e iniciada a construção do hospital e clínica para mulheres e um outro para o isolamento dos tuberculosos. [. . . $\mathrm{Na}$ falta de um hospital para psicopata [. . .] conseguimos um acordo com o Governo do Amazonas para que recebesse no Asilo dos Alienados daquele Estado, mediante pagamento pela manutenção, os doentes mentais que estão superlotando as enfermarias do Território. O Território não possui lazaretos organizados, mas apenas acampamentos no seio da mata, onde esses doentes infelizes são mantidos isolados. Restabeleceu-se o serviço de profilaxia de doenças venéreas ${ }^{105}$

Mas a principal meta no campo econômico para reabilitar o Acre, possibilitando a ele “alvorada de uma ressurreição", era implementar uma política de valorização da borracha, dando-lhe condições de competir com a produção do Oriente.

O "angustiante problema" da hevea precisava de uma solução, da instituição de medidas para a diminuição do custo de produção e, por extensão, do custo do beneficiamento do "látex", possibilitando, dessa forma, a produção da borracha fina especial, com preços estáveis e não sujeitos aos preceitos da lei, isto é, com estabilidade forçada através da adoção

\footnotetext{
${ }^{105}$ SANTOS, José Guiomard dos. Relatório apresentado ao Exmo. Sr. General Eurico Gaspar Dutra. D.D Presidente da República, pelo Major José Guiomard dos Santos, Governador Delegado da União no Território Federal do Acre referente as atividades da administração acreano no exercício de 1946. Rio Branco, 1946. p. 10.
} 
do processo Arantes, o que consistia na coagulação e defumação do látex por meio do ácido pirolenhoso bruto.

O processo Arantes foi inicialmente uma experiência inovadora cujo método de preparação possibilitou à borracha atingir preços mais animadores nas praças de São Paulo, bem como oportunizou a criação do Núcleo de Melhoramentos da Borracha em Rio Branco, chegando-se a resultados surpreendentes quanto à criação de um segundo tipo de borracha coagulada também com a seiva Arantes, mas em pranchões e não laminada, como era corrente. Esse novo método conservava apenas $55 \%$ da umidade e se achava isento de qualquer impureza ${ }^{106}$.

Esse novo método não dispensava a operação complementar de crepagem efetuada nas fábricas, porém mantinha as mesmas propriedades da borracha fina defumada pelo processo indígena, com a vantagem de não conter impurezas, apresentar menor índice de umidade e facilidade de transporte, mesmo nos altos rios, e, sobretudo, diminuir o trabalho do seringueiro em mais de 50\%, liberando-o para a atividade agrícola, entre outras, além de dispensar a utilização das lâminas Arantes.

No entanto, assinalou Guiomard Santos no relatório de 1949 que "para os seringais dos baixos rios, o emprego do primeiro tipo, os laminados, pode ser facilmente incentivado, mesmo porque os preços para esse tipo de borracha são bem melhores que a cotação para a borracha em prancha"107.

Preocupado em possibilitar o transporte da produção de borracha para os centros comerciais do país, o governo Guiomard Santos conseguiu apoio da Força Aérea Brasileira (FAB), que quinzenalmente viabilizava seu deslocamento para os mercados nacionais. Porém, à medida que se intensificava o uso da seiva Arantes, era necessário assegurar aos seringalistas transporte com maior tonelagem através de aviões comerciais. Para a consecução

\footnotetext{
106 SANTOS, José Guiomard dos. Relatório da Administração do Território Federal do Acre no Exercício de 1949. Janeiro a setembro, Rio Branco, 1949. p. 15

${ }^{107}$ Ibid. p. 16.
} 
desse objetivo o governo obteve junto à Diretoria da Companhia Cruzeiro do Sul um preço mínimo de frete para a borracha laminada, no valor de $\mathrm{C} \$ 6,00$ por quilo.

Essas iniciativas inovadoras trouxeram como resultado um aumento considerável da produção de borracha destinada, preferencialmente, para São Paulo, em vôos semanais da Companhia Aérea Cruzeiro do Sul. No entanto, o lucro com essa produção não era tão animador devido os preços das tarifas para o transporte ainda serem onerosos, apesar da redução obtida pelo governo do Território e da permanência de outras despesas referentes a colheita do látex.

Portanto, se de um lado a adoção do método Arantes incrementou a produção através das modernas técnicas utilizadas para a época, as quais possibilitaram a substituição do arcaico processo indígena, por outro lado Guiomard Santos ponderou que o governo da União deveria estipular uma subvenção à Companhia Aérea Cruzeiro do Sul "por viagem de retorno ao Acre, quando no transporte dos laminados Arantes, na base de C\$2,00 por quilo, a título de fomento e até que se tenha difundido $[\ldots]$ esse novo processo" 108 .

O governo Guiomard Santos entendia que a solução imediata para a crise da produção da borracha no Acre estava no fomento do processo Arantes, até que os preços compensadores dessa produção gerassem o capital necessário ao incremento da agricultura e da pecuária. Nessa lógica, dever-se-ia incentivar ao máximo a disseminação deste, garantindo, inclusive, por via fluvial, o transporte das pranchas e dos blocos preparados pelo referido processo.

No que se refere à produção industrial, praticamente não existia, exceto algumas pequenas indústrias de transformação tais como olarias, cerâmicas, serrarias e oficinas, entre outras.

Entre os fatores que dificultavam o desenvolvimento industrial acreano durante o governo Guiomard Santos encontravam-se:

${ }^{108}$ Ibid. p. 16. 
1 - o elevado custo da mão de obra; II - a dificuldade de transporte; III - a falta de energia elétrica nos centros urbanos durante o dia; IV - a falta de iniciativa particular; $\mathrm{V}-\mathrm{a}$ falta de gente especializada em qualquer ramo, mesmo da pequena indústria ${ }^{109}$.

Dessa forma, o Departamento de Produção do Território do Acre enfatizava que a indústria "por excelência para o Acre seria a de artefatos da borracha, com a instalação de uma fábrica aqui em Rio Branco, tendo como objetivo a produção de pneumáticos e Câmaras de $\operatorname{ar}^{, 110}$.

A afirmativa acima se justificava pelo fato de a borracha do Acre ser de grande qualidade, na medida que um terço da produção total da Amazônia era originária do Acre. Portanto, a borracha manufaturada no Território do Acre poderia encontrar um mercado promissor nas fábricas de São Paulo. No entanto, o que ocorria era a exportação da borracha em sua forma bruta para outros centros do país, onde era manufaturada, retornando beneficiada, porém encarecida de novas despesas com fretes, despachos, capatazias, seguros e outros, ficando o lucro nas fábricas paulistas. Esse fato provocava uma sangria nas finanças do Território do Acre.

O que se deduz daí? [. . .] Apenas isto: o homem da Amazônia extrai a borracha, transporta-a arcando com todas as despesas e prejuízos e depois compra a mesma borracha, já beneficiada deixando o lucro para o industrial. Forneceu a matéria prima para ser preparada e depois vai buscar o produto de seu suor, pagando frete duas vezes e os lucros, a duas fontes: o intermediário, que era o Banco de Crédito da Amazônia, e o consórcio fabri1 $^{111}$.

Essa realidade era difícil de ser superada pelo menos no curto prazo, o que os técnicos do Departamento de Produção propunham, pelo menos a curto tempo, era que a lavagem e a crepagem $^{112}$ da borracha poderiam ser executadas no Acre, com a respectiva classificação

\footnotetext{
${ }^{109}$ Ibid., p. 39.

${ }^{110}$ Ibid., p. 39.

${ }^{111}$ Ibid., p. 39

${ }^{112}$ Processo técnico de beneficiamento da borracha para posterior classificação
} 
primária da borracha bruta pela Agência do Banco de Crédito da Borracha, evitando-se, dessa forma, os sérios prejuízos resultantes para os seringalistas.

Ponderam, ainda, esses técnicos que o "processo Arantes [. . .] se disseminado [poderia ser] um forte passo para a industrialização da borracha, de vez que o produto laminado, é aceito em São Paulo como borracha semi-industrializada" ${ }^{, 13}$.

Importante destacarmos a importância da III Conferência Econômica da Borracha, ocorrida em Belém, no período de 7 a 11 de setembro de 1949, quando o Dr. Valério Caldas de Magalhães, na época diretor do Departamento de Produção, recebeu a incumbência de representar no referido conclave o governo do Território do Acre, que considerava o evento fundamental para a implementação de uma política de superação da crise da produção e comercialização da borracha do Acre.

Nesse encontro, que contou com a presença de várias delegações representantes dos governos da Amazônia, do crédito, da produção e da indústria, o representante do Acre, conforme prévia autorização do governador Guiomard Santos, proferiu uma palestra em que enfatizou não só a crise da borracha na região, mas, sobretudo, as reivindicações dos seringalistas, além de ter conseguido incluir na agenda de discussão da mencionada conferência, os pontos fundamentais do trabalho organizado pelo Departamento de Produção, a saber:

- Adoção e fomento do processo Arantes;

- Plantio sistemático da seringueira, principalmente às margens dos rios francamente navegáveis;

- Fomento da produção agrícola, com financiamento a longo prazo, melhoria dos transporte com modificação da frota do SNPP, adquirindo-se navios a óleo e próprios para os grandes e pequenos rios, subvencionando-se, ainda, as embarcações particulares que tinham linha regular;

- Taxa mínima para o transporte da borracha;

- Reestruturação do Banco da Borracha, que passaria a denominar-se Banco Econômico da Amazônia;

- Liberação, gradativa, do monopólio de venda da borracha;

- Venda livre, desde já para os laminados de qualquer espécie, sobretudo os preparados pelo processo Arantes, liberados que ficariam do Banco da Borracha;

${ }^{113}$ Ibid., p. 40. 
- Pedido ao Congresso para que seja elaborada, o quanto antes, nova lei agrária $^{114}$.

Dos pontos acima apresentados, apenas um não foi aprovado pela plenária: o que propunha a venda livre dos laminados de qualquer espécie devido à forte oposição do Banco da Borracha. Outro ganho político significativo foi a participação do Acre, através da Associação Comercial do Acre, na composição do Conselho Consultivo da nova organização de crédito, que conforme proposta do Anteprojeto de lei “modifica o Decreto-lei de $\mathrm{n}^{\mathrm{o}} 5.185$, de 12 de janeiro de 1943 e a Lei 86, de 8 de setembro de 1947, e dá outras providências”.

As modificações preconizadas pelo referido Anteprojeto compreendiam várias questões, a saber:

[. . .] Prorrogava a continuidade da exploração dos seringais pelos seringalistas que exerceram suas atividades desde produtivas, regularmente, até a data da aprovação desta lei, desde que se trate de seringais financiados pelo Banco de Crédito da Amazônia S. A.; nova distribuição do valor líquido apurado com a venda de borracha ao Banco de Crédito da Amazônia S. A, de acordo com os preços de compra fixados pela Comissão Executiva de Defesa da Borracha; assegurava ao governo federal a exclusividade das operações finais de compra e venda da borracha produzida no Brasil e importada do exterior, quer se trate de produto a ser industrializado no país, quer se destine à exportação ou reexportação; determinava que o governo federal delegasse ao Banco de Crédito da Amazônia a competência de operacionalizar o item citado anteriormente; modificava a denominação do Banco de Crédito da Borracha S. A. para Banco de Crédito da Amazônia S. A.; determinava que o Banco de Crédito da Amazônia S. A deveria ser administrado por uma diretoria integrada por um Presidente e quatro diretores, todos brasileiros e residentes no país; determinava o livre direito de nomeação e demissão do Presidente do Banco de Crédito da Amazônia S. A pela Presidência da República; instituía que os diretores do Banco de Crédito da Amazônia S. A tivesse um mandato de quatro anos, devendo ser eleitos pela assembléia geral dos acionistas, devendo, pelo menos, dois deles ser profissionais de atividade bancária; determinava que as resoluções da diretoria do Banco de Crédito da Amazônia S. A. deveriam ser aprovadas por maioria de votos, cabendo ao Presidente, além do voto pessoal, o de qualidade; determinava a criação de um Conselho Consultivo com representação dos estados, Território, Associações Comerciais ou de Seringalistas; definia que o Conselho Consultivo deveria reunir-se pelo menos uma vez a cada trimestre; instituía no Banco de Crédito da Amazônia S. A, um fundo de fomento a produção da borracha, determinando $20 \%$ das

${ }^{114}$ À MARGEM da III Conferência econômica da borracha - palestra pronunciada ao microfone da ZYD-9, pelo Dr. Valério Caldas de Magalhães. O Acre. Rio Branco: órgão oficial do governo do Território do Acre, nov. 1949, p. 1. 
dotações anuais previstas no artigo 199 da Constituição Federal para a valorização econômica da Amazônia pelo prazo de vinte anos; estabelecia as dotações de quarenta milhões de cruzeiros e de cento e cincoenta milhões de cruzeiros concedidos pelas leis ns. 462, de 30 de outubro de 1948, e 590 de 11 de setembro de 1948, respectivamente, passariam a fazer parte do fundo de fomento a produção da borracha ${ }^{115}$.

Nos anos 50, a extração do látex ainda era realizada através das seringueiras nativas e não nas de cultivo pois

[. . .] essas plantações, feitas de pé franco têm pequeno rendimento. Uma "estrada de 150 seringueiras de planta produz de 3 a 6 litros de leite de seringa, contra 10 a 40 litros da mesma estrada" de seringueiras silvestres. Não é questão de sementes. Muitas dessas seringueiras foram plantadas com as sementes das melhores árvores dos seringais dos altos rios. Mas o fato é que a nossa seringueira é uma árvore da floresta, onde ela vive em determinada associação vegetal. Retirada dessa associação para plantações puras, fora da sua sinusia natural, ela não se desenvolve satisfatoriamente. Mesmo em bons solos de várzea, mesmo nas férteis argilas do Acre, as plantações de seringueiras não apresentam a exuberância nem a produtividade dos espécimes silvestres ${ }^{116}$.

Internamente as ligações entre a sede do seringal e a barraca do seringueiro faziam-se por meio dos "varadouros". Alguns seringueiros realizavam esse trajeto a pé, enquanto outros utilizavam animais ou até canoas.

As relações entre o seringueiro e o seringalista realizavam-se, particularmente, na base da palavra e não de documentos, e o aviamento ainda era dominante - o seringueiro recebia do seringalista o "aviamento" no período do inverno, que lhe era fornecido em mercadorias e raramente em espécie, e pagava ao seringalista no verão (maio a dezembro) com a produção da borracha.

O processo técnico de extração dos látex utilizado largamente ainda era o da defumação, embora o laminado Arantes tivesse ampla aceitação por parte da indústria de artefatos de borracha e de preços mais vantajosos na tabela de preços do Banco de Crédito da

\footnotetext{
115 À MARGEM da III Conferência econômica da borracha - palestra pronunciada ao microfone da ZYD-9, pelo Dr. Valério Caldas de Magalhães. O Acre. Rio Branco: órgão oficial do governo do Território do Acre, nov. 1949, p. 1.

${ }^{116}$ BONFIM, Sócrates. Reflexões em termo da valorização da Amazônia, mimeografado. p. 19. In: GUERRA, Antônio Teixeira. Estudo Geográfico do Território do Acre. Rio de Janeiro: IBGE, 1955, p. 191.
} 
Borracha. Porém, como a adoção deste implicava investimentos para aquisição de maquinários e de certos procedimentos técnicos, os seringalistas, na sua maioria, não o adotaram.

[. . .] encargos de pequena maquinaria e equipamento, exigidos por uma organização dessa ordem, aliados aos enxutos indispensáveis a um produto de elevado valor comercial... e mais além: "os lotes de borracha chegaram a esta capital (Rio Branco) com grande proporção de lâminas oxidadas, fato este que levou a firma produtora, Chaar \& Cia., a desinteressar-se do assunto" [. . . ] que o pouco cuidado ou ignorância na manipulação - já que os "laminados" não foram devidamente resguardados dos raios solares parece ter sido fator importante na pouca aceitação do processo Arantes. [.. .] seria temeridade e inadvertência a difusão em larga escala, a generalização do laminado Arantes a todos os quadrantes do território, onde as condições de transporte variam enormemente, em função de duas estações climáticas "verão" e "inverno" [. . .] a borracha em pranchas, processo pelo qual se obtém o tipo denominado "Acre-fina, em pranchas"; nesse processo é também utilizado o ácido pirolenhoso bruto. Descreve, também, o "sernambi da fina", obtido por coagulação espontânea, mas sujeito "ao rápido envelhecimento, podendo degradar-se no prazo de um ano" 117 .

A adoção da prática da lavoura de subsistência na maioria dos seringais, que garantia a sobrevivência dos seringueiros, na medida que a produção da borracha no Território do Acre apresentou como períodos de grandes picos os anos de 1927, 1936 e 1948, sendo este último de maior produção no Acre, tornou-se vital.

A partir de 1950, a queda da produção tornou-se inevitável e a produção por município é a seguinte:

117 FREIRE, Francisco Custódio. Novos meios de produção da borracha. Território Federal do Acre. Departamento de Produção. Mimeografado. In: GUERRA, Op. Cit. p. 196. 


\section{Quadro 5}

Produção da Borracha no Acre - 1950

\begin{tabular}{l|c}
\hline \multicolumn{1}{c|}{ Local } & Quantidades (Kg) \\
\hline Rio Branco & 1.854 .157 \\
Xapuri & 1.483 .092 \\
Sena Madureira & 1.197 .012 \\
Tarauacá & 763.989 \\
Cruzeiro do Sul & 748.825 \\
Brasiléia & 685.689 \\
\hline
\end{tabular}

Fonte: GUERRA, Antônio Teixeira. Estudo Geográfico do Território do Acre. p. 208.

Teixeira Guerra, no seu relatório, demonstra que depois de 1950, a produção da borracha era maior no Alto Purus que no Alto Juruá, bem como as lideranças de Rio Branco e Cruzeiro do Sul, respectivamente, como polos produtivos, no Purus e Juruá, conforme evidenciam os quadros 5, 6 e 7 .

\section{Quadro 6}

Produção da Borracha na Zona do Alto Purus - 1952

\begin{tabular}{l|c|r|r|r|r|r}
\hline Especificação & $\begin{array}{c}\text { Unidade } \\
\text { de } \\
\text { Referência }\end{array}$ & $\begin{array}{c}\text { Rio } \\
\text { Branco }\end{array}$ & $\begin{array}{c}\text { Sena } \\
\text { Madureira }\end{array}$ & Xapuri & Brasiléia & Total \\
\hline Caucho & Quilo & 23 & - & - & - & 23 \\
Fine em péla & “ & 2.062 .104 & 853.036 & 1.222 .265 & 483.290 & 4.620 .695 \\
Fina laminada & “ & 3.800 & 131 & - & - & 3.931 \\
Sernambi-caucho & “ & 2.761 & 23.004 & 1.005 & 35 & 26.905
\end{tabular}




\begin{tabular}{l|l|r|r|r|r|r} 
Sernambi-rama & “ & 95.542 & - & 3.945 & 5.964 & 104.451 \\
Sernambi-seringa & “ & 77.436 & 54.347 & 109.465 & 37.829 & 279.076 \\
\hline Total & & 2.240 .666 & 930.518 & 1.366 .680 & 527.118 & 5.035 .021 \\
\hline
\end{tabular}

Fonte: Dados estatísticos fornecidos pelo Departamento de Geografia e Estatística do Território Federal do Acre. In: GUERRA, Antônio Teixeira. Estudo Geográfico do Território do Acre. p. 209.

\section{Quadro 7}

\section{Produção da Borracha na Zona do Alto Juruá - 1952}

\begin{tabular}{l|r|r|r|r|r}
\hline \multicolumn{1}{c|}{ Especificação } & $\begin{array}{c}\text { Unidade de } \\
\text { Referência }\end{array}$ & $\begin{array}{c}\text { Cruzeiro do } \\
\text { Sul }\end{array}$ & Tarauacá & Feijó & \multicolumn{1}{c}{ Total } \\
\hline Caucho & 103 & - & - & 103 \\
Fine em péla & 1.000 .391 & 887.728 & 743.389 & 2.631 .508 \\
Fina laminada & - & - & - & - \\
Sernambi-caucho & 2.259 & 579 & 1.441 & 4.279 \\
Sernambi-rama & 6.448 & 4.229 & - & 10.677 \\
Sernambi-seringa & & 31.771 & 24.713 & 34.696 & 91.180 \\
\hline Total & & 1.040 .972 & 917.249 & 779.526 & 2.737 .747 \\
\hline
\end{tabular}

Fonte: Dados estatísticos fornecidos pelo Departamento de Geografia e Estatística do Território Federal do Acre. In: GUERRA, Antônio Teixeira. Estudo Geográfico do Território do Acre. p. 209.

Em relação à produção da castanha, é notório destacarmos que esta era desenvolvida, fundamentalmente, no Alto Purus, na medida que no Alto Juruá não existiam castanhas, além da oscilação da produção em decorrência do transporte e do preço do produto no mercado.

Este produto, que, podemos dizer, já foi, em épocas passadas quando a borracha perdeu, pelo seu baixo preço, a expressão econômica, o esteio da economia amazônica e encontra-se, hoje, quase completamente afastado do meio comercial, apesar do alto preço que vem encontrando nos meios consumidores. É um produto, hoje, de grande valor aquisitivo e que está 
quase afastado da balança comercial do Território, o que constitui um verdadeiro paradoxo, podemos dizer, uma aberração do metabolismo econômico da região. Onde a origem da causa que determina tão estranho quão prejudicial indiferentismo? Falta de senso econômico? Comodismo? Ou enfarto de lucros fáceis? O fenômeno está aí, existe, processa-se de modos desastrosos para a economia da região ${ }^{118}$.

Como se explica a crise da borracha pós Segunda Guerra Mundial?

Para João Kubitschek de Figueiredo, governador do Território do Acre (1952), as causas principais teriam sido:

1 - a não fixação à terra da grande riqueza obtida;

2 - não se ter cuidado de melhorar a técnica de exploração e exportação da borracha;

3 - os processos racionais de plantio, seleção, colheita e produção da goma elástica, por nossos rivais da Ásia [Destes, aponta o terceiro como o mais relevante. A prova disto é que a produção dos seringais plantados é superior a dos nativos, e, além do mais, as atividades dos seringueiros são realizadas com mais facilidade, segurança e maior rendimento $]^{119}$.

Para esse governante, a reabilitação do Acre, do ponto de vista econômico, passava, necessariamente, pela superação da exploração de apenas seringais nativos. Notório ainda destacarmos que a riqueza produzida pela exploração da borracha não deixou suas "marcas" no Acre, na medida que os seringalistas investiam os seus ganhos, preferencialmente, em Belém, Manaus, Fortaleza ou Rio de Janeiro.

\section{Quadro 8}

Produção da Castanha (1920 - 1950)

\begin{tabular}{c|r|r}
\hline Ano & Quantidade $(\mathrm{Kg})$ & Valor da Produção (Cr\$) \\
\hline 1920 & 99.900 & 146.854 \\
1921 & 645.650 & 754.119 \\
1922 & 175.700 & 191.864 \\
1923 & 90.200 & 83.455 \\
1924 & 148.200 & 261.128 \\
1925 & 497.950 & 1.236 .410 \\
& & \\
${ }^{118}$ GUERRA, Op. Cit. p. 212. & & \\
${ }^{119}$ Ibid. p. 206 - 207 &
\end{tabular}




\begin{tabular}{r|r|r}
1926 & 21.050 & 20.208 \\
1927 & 485.400 & 912.552 \\
1928 & 597.700 & 1.101 .561 \\
1929 & 466.450 & 538.283 \\
1930 & 2.332 .900 & 4.119 .901 \\
1931 & 1.967 .550 & 2.666 .030 \\
1932 & 4.268 .000 & 4.161 .300 \\
1933 & 2.631 .700 & 2.613 .273 \\
1934 & 7.437 .150 & 7.935 .439 \\
1935 & 5.360 .800 & 7.537 .285 \\
1936 & 5.403 .850 & 10.202 .469 \\
1937 & 4.220 .400 & 15.248 .305 \\
1938 & 4.736 .400 & 8.596 .566 \\
1939 & 3.374 .107 & 4.850 .024 \\
1940 & 6.107 .538 & 4.922 .811 \\
1941 & 2.388 .200 & 4.227 .114 \\
1942 & 4.820 .444 & 10.161 .428 \\
1943 & 172.627 & 389.502 \\
1944 & 28.250 & 20.340 \\
1945 & 59.500 & 95.000 \\
1946 & 3.360 .776 & 17.364 .475 \\
1947 & 3.000 .000 & 10.000 .000 \\
1948 & 1.191 .112 & 1.301 .200 \\
1949 & 3.883 .955 & 6.988 .870 \\
1950 & 1.768 .750 & 5.120 .200 \\
\hline
\end{tabular}

Fonte: "Castanha do Pará" - Serviço de Estatística da Produção do Ministério da Agricultura, 1952. In: GUERRA, Antônio Teixeira. Estudo Geográfico do Território do Acre. p. 211.

De acordo com o quadro acima, percebe-se o caráter irregular da produção da castanha, tendo-se o ano de 1940 como o de maior percentual e o ano de 1926, como o de menor total, ressaltando-se que 1940 corresponde ao início da Segunda Guerra Mundial e 1926, ao pós Primeira Guerra Mundial e crise da economia gomífera, após a euforia do $1^{\circ}$ Surto da borracha (1870-1912).

Em relação à produção da madeira até fins dos anos 50, destacamos sua relativa significação, na medida que era grande a variedade de madeiras exploradas na região, com destaque para o águano e o cedro (produtos de exportação), e os municípios de maior exploração eram Rio Branco e Feijó, e os de menos, Xapuri e Brasiléia. 


\section{Quadro 9}

\section{A Madeira no Acre}

\begin{tabular}{l|c|c|c}
\hline \multicolumn{1}{c|}{ Especificação } & $\begin{array}{c}\text { Produção total } \\
\mathbf{m 3}\end{array}$ & $\begin{array}{c}\text { Preço por } \\
\text { unidade }\end{array}$ & $\begin{array}{c}\text { Valor total } \\
\text { (Cr\$) }\end{array}$ \\
\hline Madeiras em geral & 36.387 & - & $13.797 .770,00$ \\
Águano & 14.021 & 453,40 & $6.356 .900,00$ \\
Cedro & 12.119 & 329,20 & $3.989 .770,00$ \\
Outras madeiras & 10.247 & 336,80 & $3.451 .100,00$ \\
\hline
\end{tabular}

Fonte: GUERRA, Antônio Teixeira. Estudo Geográfico do Território do Acre, p. 213.

Merece destacarmos que a exploração de madeira teve o seu esplendor no período de 1935 até 1950, pois as toras exportadas eram classificadas por qualidade, transportadas por um "engenho" até as margens do rio e de lá carregadas pela própria correnteza, fazendo-se jangadas, até Manaus, de onde seguiam para o exterior, sobretudo a Inglaterra. Essa atividade econômica era realizada pelas serrarias manuais, pois não existiam serras elétricas.

Como atividades transitórias e complementares à produção da borracha, tinha-se o extrativismo vegetal (carvão vegetal, lenha, palhas diversas, paxiúba, óleos vegetais, fibras diversas entre outros) e o extrativismo animal (couros e peles de animais silvestre e o pescado, dentre outros), sendo a caça e a pesca praticadas para obtenção de carne fresca destinada à alimentação do seringueiro, enquanto o couro e peles enviados para Belém e Manaus.

No campo agrícola, a lavoura era pouco difundida. Os instrumentos de trabalho se restringiam à enxada, terçado e machado e os poucos existentes eram utilizados nos campos experimentais agrícolas existentes no Território. "Também não poderia ser de outra maneira, tendo em vista o grau de cultura do homem rural da região e a prática de cultivo adotado. De modo geral, o homem não era o dono da terra, e os poucos lavradores que existiam estavam 
sempre localizados perto dos centro urbanos - aliás, fato perfeitamente explicável devido à circunstância de serem estes os mercados consumidores"120.

Nesse ramo de atividade econômica destacavam-se como culturas temporárias e permanentes a mandioca, feijão, milho, arroz, abacaxi, amendoim, batata-doce, cana-deaçúcar e café, entre outras.

A produção bovina era incipiente. O gado era comprado na Bolívia, e ficava "invernando" no campos de uma fazenda até chegar ao seu destino (Rio Branco), as vezes clandestinamente. Portanto a carne de gado consumida no Território era importada da Bolívia, exceto no caso dos municípios do Alto Juruá que, às vezes, a importava do Estado do Amazonas.

[. . .] o gado era comprado na região de Moxos, Bolívia, e no seu itinerário segue pelo rio Beni, passando o rio Madre de Diós, o rio Manuripe, o rio Bolívar e depois entra em Tauamanu, atravessa o seringal Riacho de Areia (local onde o gado fica descansando). Daí atravessa o seringal Itu - já no Brasil - , onde existem campos, seguindo por terra até Rio Branco. O gado comprado na Bolívia é trazido por vaqueiros bolivianos até Rio Branco. De modo geral a boiada levava para ir de Moxos até Rio Branco, em média, uns 30 dias. O pagamento do vaqueiro era feito por viagem, o qual oscilava muito. Além do pagamento em dinheiro, recebe ainda o rancho, que é constituído de arroz, macaxeira, charque, sardinha, açúcar, café e banha ${ }^{121}$.

Não existiam grandes fazendas, sendo prática comum a existência de fazendolas que praticavam várias atividades econômicas, inclusive o extrativismo de borracha e castanha.

Pelo exposto, se evidencia que a economia acreana atravessou a década de 1950 e chegou até o início dos anos 60, tendo como principal atividade o extrativismo da borracha, apesar da crise que caracterizará este setor após o término da "Batalha da Borracha", pois na pauta das exportações do Território do Acre, a borracha estava ainda em primeiro lugar,

\footnotetext{
${ }^{120}$ Ibid. p. 220.

${ }^{121}$ Ibid. p. $246-247$.
} 
seguida da madeira, couro e peles, castanha e madeira, havendo alterações de posição nos quatro últimos anos subseqüentes a 1950.

\section{Quadro 10}

\section{Exportação de Borracha (1945 - 1952)}

\begin{tabular}{c|r|r|r|r}
\hline \multirow{2}{*}{ Período } & \multirow{2}{*}{ Peso em (Kg) } & Valor em (Cr\$) & \multicolumn{2}{|c}{ Diferença para + ou - sobre 1947 } \\
\cline { 4 - 5 } & & & Peso (Kg) & Valor (Cr\$) \\
\hline 1945 & 7.351 .531 & 123.225 .706 & -3.451 .630 & -55.594 .987 \\
1946 & 9.414 .179 & 154.048 .247 & -1.388 .982 & -24.772 .446 \\
1947 & 18.803 .161 & 178.820 .693 & - & - \\
1948 & 9.600 .440 & 142.507 .200 & -1.202 .721 & -36.313 .493 \\
1949 & 8.340 .315 & 123.620 .055 & -2.462 .846 & -55.200 .638 \\
1950 & 7.481 .420 & 130.296 .898 & -3.321 .741 & -48.523 .795 \\
1951 & 8.213 .202 & 176.964 .080 & -2.589 .959 & -1.856 .613 \\
1952 & 10.265 .201 & 206.484 .465 & -537.960 & +27.663 .772 \\
\hline
\end{tabular}

Fonte: Raul Arantes Meira (Exportação Geral) In: GUERRA, Antônio Teixeira. Estudo Geográfico do Território do Acre, p. 253.

E à medida que a produção da borracha deixava de "viver os seus anos de glória", o poder econômico e político dos seringalistas será, gradativamente, "solapado", inclusive com seu endividamento junto ao Banco de Crédito da Borracha e a posterior venda de grande parte dos seringais acreanos a investidores do Centro Sul. Serão outros os novos "donos do Acre". Nesse processo, o seringueiro-extrator expropriado de suas terras e raízes irá "pagar o preço maior" da derrocada do extrativismo no Acre. 


\section{3 - Autonomia já!}

O Acre quer ser Estado. Então que o Juruá seja Território, afinal o Juruá também é Brasil e derramou sangue fazendo recuar os peruanos, desde a boca do Môa até os limites atuais.

João Mariano da Silva

A anexação do Acre ao território nacional não se constitui na solução para a "questão do Acre", na medida que não contemplou as aspirações emancipacionistas das forças políticas que fizeram a "Revolução Acreana", as quais, ao longo do processo da luta contra a Bolívia dividiram-se em vários grupos com projetos distintos para a região.

Havia aqueles, como Galvez, que defendiam a instauração de um regime republicano, porém subordinado e obediente à “mãe-pátria'. Alguns outros, mais ousados, com suas idéias separatistas, propunham a separação do Acre do território nacional formando um novo país, enquanto a maioria, representada pela oligarquia dos Carvalhos defendia a anexação do Acre ao território nacional com obediência à República e sua Constituição, e, destes, destacavamse os que relacionavam anexação à autonomia política do Acre. Anexação sim, mas com soberania política.

No confronto desses projetos diferenciados, venceu a imposição do governo federal, que legitimou a luta por um Acre brasileiro, incorporando-o, porém, sob a tutela da União.

Nessa perspectiva, a instituição da condição de Território se constitui um "freio" ao mandonismo das forças políticas locais quanto a se afirmarem frente ao poder nacional.

Portanto, as raízes do movimento autonomista estão fincadas na luta dos patrõesseringalistas por um Acre brasileiro.

Nesse sentido, é pertinente ressaltarmos que após a proclamação da República, mais precisamente no período convencionalmente denominado de "República Velha", quando se consolidou a hegemonia das oligarquias paulista e mineira no cenário nacional, a perspectiva 
que se configurou para os grupos políticos do Norte e Nordeste foi resistir as intervenções do governo federal nas suas "áreas de influência" ou aliar-se a este desde que fossem favorecidos em seus interesses regionais, numa política de compromisso caracterizada pelo "é dando que se recebe".

No caso do Acre, considerando-se a sua importância econômica devido à produção da borracha e à participação dela nas exportações brasileiras e, ainda, à tradição dos patrõesseringalistas de serem praticamente absolutos nos seus domínios, onde se constituíam a expressão da lei, a instituição do sistema jurídico de Território os alijava da estrutura do poder local.

Portanto, o brado “autonomia já!” caracterizou de forma contundente a rejeição à imposição da ordem republicana na região, acrescentando-se que as administrações dos “estranhos ao ninho" - Prefeitos Departamentais e Governos Territoriais -, com suas gestões efêmeras, exceto honrosas exceções, também contribuíram para agudizar o sentimento de repulsa à ingerência institucional do governo federal no Acre.

É nesse contexto que se insere o levante de 1910 em Cruzeiro do Sul, quando os seringalistas e comerciantes de maior peso econômico se rebelaram e depuseram as autoridades constituídas.

Manifestando-se a respeito do alto grau de tensão política que a luta pela autonomia tinha atingido no Departamento do Alto Juruá, o Prefeito Departamental Deocleciano Souza, do Departamento do Alto Acre assinalou, que

[. . . e é impossível ao menos por enquanto constituir-se em só um Estado o Território do Acre, sob uma única direção administrativa.

Para resolver tão complexo problema com verdadeira orientação e critério, caso estejam os poderes públicos propensos a declararem autônomo o Território do Acre, há dous caminhos a seguir: Entrar em accôrdo com o Governo do Amazonas para uma permuta do Departamento do Alto Juruá por outra extensão territorial que o compense banhada pelo rio Purus, com o que, naturalmente, não se conformarão os habitantes daquella região ou crear pelo menos dous "novos Estados, um abrangendo o Alto-Acre e o Alto Purús e o outro formado pelo Alto Juruá. Sem autonomia é preferível conservar-se a organização actual, uma vez que disponham as prefeituras de 
renda sufficientes para ocorrer às despezas necessarias aos encargos nos Departamentos $^{122}$.

Fica evidente que não havia interesse do governo federal em "conceder" a autonomia política, mas impor o seu domínio sob os patrões-seringalistas e, dessa forma, submeter a região à Ordem necessária ao progresso que a República brasileira defendia.

No projeto das forças políticas que fizeram a República, a autonomia do Acre só poderia ser instituída quando os ímpetos emancipacionistas aguerridos dos patrõesseringalistas fossem contidos pelo poder da força militar e da lei. Tendo a construção da Ordem como tarefa indispensável em todo território nacional, o governo republicano postergava o atendimento a estes quanto à liberdade política do Território do Acre.

A autonomia, nesse sentido, passa a ser vista como um horizonte a ser alcançado no futuro, sem ameaças às estruturas de poder da República. Um Acre ordeiro era um Acre em que os fatos se comportariam segundo o esperado, o previsível, o desejável. E, como estratégia de desarticulação, o governo federal deslocou no discurso a luta pró-autonomia do regional para o nacional. A autonomia como dádiva e não como conquista.

Embora não se cogite de dar ao Acre imediata autonomia, mas sendo ella uma aspiração nacional, desde que esteja em condições idênticas aos demais Estados da Federação, convém que aja o governo no sentido de prepará-lo mais breve possível, para dar aos seus habitantes a satisfação de poderem usar e gozar dos direitos políticos que são conferidos pela Constituição da República a todos os brasileiros ${ }^{123}$.

Outro aspecto a ressaltarmos é que o processo de colonização do Acre não ocorreu segundo a tradição agrária, mas de conformidade com o sistema extrativista tradicional que a

\footnotetext{
122 SOUZA, Deocleciano Coelho de. Relatório apresentado ao Exmo. Sr. Ministro do Interior e Justiça. Dr. Esmeraldino Olympio de Torres Bandeira; Prefeito interino do Departamento do Alto-Acre, Dr. Deocleciano Coelho de Souza; In: Acre: Relatórios de Governo (1906 - 1910). Rio Branco: Tribunal de Justiça do Estado do Acre, 2003 , p. 126. ${ }^{123}$ BESOURO, Gabino. Relatório de governo apresentado ao Exmo. Sr. Ministro do Interior e Justiça, Dr. Augusto Tavares de Lyra pelo coronel Gabino Besouro, Prefeito do Departamento do Alto Acre, em 1909. In: Acre - relatórios de governo (1906-1910). Rio Branco: Tribunal de Justiça do Estado do Acre, 2003, p. 63.
} 
partir de 1912 entrou num processo falimentar, embora tenha tido um surto de desenvolvimento da produção durante a Segunda Guerra Mundial.

O reconhecimento da possibilidade histórica da invenção de uma sociedade extrativista nutrida pelo "leite da mãe-seringueira" era impensável, ahistórico, para o Estado republicano.

Como conceder autonomia a uma região cuja população era majoritariamente masculina, as comunicações deficitárias e dependentes do comportamento da natureza, as doenças tropicais grassavam impiedosas os que chegavam, especialmente os migrantes nordestinos com suas estruturas físicas fragilizadas pelas condições da vida anterior, os rigores da viagem do Nordeste ao Acre e a vivência no seio da "selva", onde a família, enquanto grupo social devidamente organizado e estável, ainda era reduzida e a perspectiva da maioria dos que vinham para a região era "ganhar dinheiro" e retornar aos seus locais de origem? Essas e outras indagações nos idos das primeiras décadas do século XX marcavam a visão do Estado brasileiro e seus representantes acerca do Acre.

Radicar a população ao solo, estimulando-a que se dedique a lavoura é o principal escopo para o desenvolvimento do Acre e o primeiro passo para sua autonomia. Sem população de vida sedentária fixa, que tome amor ao solo de onde tira os meios de subsistência e que se torne o berço dos seus filhos, fazendo o homem retirar da mente o pensamento de voltar à terra natal, nada se conseguirá de permanente, duradoura para elevação deste Território à altura dos demais Estados ${ }^{124}$.

Nessa perspectiva, o “olhar” que os representantes do Estado Republicano construíram acerca do Acre era de que tanto a terra quanto a gente precisavam ser "domadas" pela razão, ciência, progresso. E a autonomia viria como um corolário a esse processo. Nessa direção, negavam no discurso e na ação as reivindicações autonomistas dos grupos políticos regionais.

${ }^{124}$ Ibid., p. 49. 
Portanto, a política implementada no Território do Acre até 1920 foi de estabelecer as bases administrativas e jurídicas para instituir o "reino" da ordem, lei e civilidade.

Com a unificação dos Departamentos em 1920, mais precisamente com o governo de Hugo Carneiro (1928), o ideário de fincar a civilização na "selva" ganhou contornos mais estáveis e visíveis. "começou a haver justiça no Acre. Os crimes que assombravam a vasta região acreana decresceram immediatamente. Os syntomas alarmantes para os que se dirigiam às suas plagas foram sendo espantados do solo e o ar começou a ser respirável”,125.

Dessa forma, a gestão do governador Hugo Carneiro se constituiu num marco em fins da década de 1920 e, embora, tenha investido mais em Rio Branco, Capital do Território, em termos de infra-estrutura urbana, na perspectiva de instituir um modelo urbanista moderno, o que implicava a substituição da madeira "por sólidas construções de alvenaria, que afirmarão uma era de verdadeira consolidação da cidade metrópole do Território" ${ }^{\text {"126 }}$, esse governante se destacou por implementar uma Ordem social urbana com a formulação e implantação do Código de Posturas da cidade de Rio Branco, que passou a vigorar em 1929.

Esse documento extenso e detalhado, composto de 319 artigos, regulava toda a vida econômica, social, política e cultural da cidade de Rio Branco. Merece destaque assinalarmos que outras localidades do Acre, em momentos históricos diferentes, também tiveram os seus Códigos de Posturas Urbanas.

A seleção dos bons e a segurança pública se constituíram no imaginário de Hugo Carneiro elementos fundamentais à invenção do Acre-estado. Autonomia só com manutenção da ordem interna e desenvolvimento econômico.

E o que se passa na Capital do Território, com pequenas alterações se reproduz nas demais cidades e villas, até onde chegam as efficazes providencias do governador no sentido de rehabilitar o Acre, extinguindo as

\footnotetext{
${ }^{125}$ SELVA, João da. Rehabilitação do Acre: atividades acreanas sob a administração Hugo Carneiro 1927 - 29. Manaus: Armazéns Palácio Real, 1929, p. 10.

${ }^{126}$ Ibid. p. 21.
} 
tradicções que não o recommendavam, tornando-o digno de ser amanhã um Estado da Federação brasileira ${ }^{127}$

Higiene, civilidade, beleza e ordem são os pilares do progresso no imaginário urbano de Hugo Carneiro. Cada coisa em seu lugar, nada fora do lugar, cabendo ao Estado vigiar e punir.

No seu governo foram edificados o Quartel da Força Policial, o Mercado Municipal e o Palácio de Rio Branco, além da agência do Banco do Brasil, do stadium do Rio Branco Football Club, da Inspetoria Agrícola Federal, do Instituto Histórico e Geográfico do Acre, o Tribunal de Apelação, do Juizado Federal, a Santa Casa de Misericórdia, do Hospital dos Tuberculosos, da Estação Climatológica, do Aprendizado Agrícola, da Mesa das Rendas Federais, de Capitania dos Portos, dos grupos escolares e escolas isoladas. A ordem estava sendo materializada fisicamente.

Importante considerarmos que a preocupação de construir no urbano as "cidadelas da ordem" implicou também "esconder" os degenerados do corpo, mente ou espírito. A cidade deveria ser o locus dos bons e sãos. A "teoria da degenerescência" e suas implicações nos vários campos da ciência e da cultura chegaram à "selva".

O controle social, político e ideológico se apresentava como o mecanismo mais eficaz para a instituição da razão, ordem e progresso. Mas era necessário que o Estado oligárquico brasileiro se convencesse de que o Acre estava vivendo segundo os cânones da civilidade. Nesse sentido, Hugo Carneiro viabilizou a participação do Acre em vários congressos científicos, pois só dessa forma a autonomia poderia ser concedida.

Portanto, nos anos 20 e 30 do século XX, caracterizados internamente pela retração da economia gomífera, o caráter aguerrido das forças políticas regionais pró-autonomia arrefeceu, sobretudo frente à ofensiva do governo federal de "preparar" o Acre para a tão sonhada emancipação.

${ }^{127}$ Ibid. p. 57. 
Nos anos de 1940, o Acre passou por um novo surto de modernização, notadamente durante o governo Guiomard Santos (1946-50).

Esse governante diferentemente dos seus antecessores, estabeleceu o discurso e a articulação política, como os elementos fundantes da relação estabelecida com as forças políticas do Acre. No "Discurso-Programa" (síntese do programa de governo) proferido durante a sua posse, na escadaria do Palácio Rio Branco, deixou evidente a intenção de transformar o Acre, principalmente Rio Branco, em termos sociais, econômico, político e cultural, no entanto, para implementar as mudanças necessitava construir uma base política para viabilizar o projeto de modernização.

Nesse sentido, o discurso, a palavra, foi a estratégia que usou para dominar, persuadir e convencer.

De narrativa épica, poética, recheado de metáforas, o Discurso-Programa, além de expressar o caráter subjetivista da "fala" de Guiomard Santos, deu ênfase à história como progresso que leva à construção de uma sociedade melhor no futuro.

Eu vos peço crédito. Mas crédito no tempo e não somente nas vossas esperanças [. . .]. Tampouco desejo saber agora de politicagem, divergências, desunião, queixas, lutas inglórias, injustas e estéreis. Concitovos para uma longa experiência em outro estilo. Consistirá em resgatarmos o sacrifício dos heróis que nos deram o Acre $^{128}$.

Nesse discurso articulado, formulado de acordo com as circunstâncias e a audiência a quem se dirigia, Guiomard Santos, embora tivesse como base de sustentação política os seringalistas, comerciantes e funcionários mais graduados que integravam o Partido Social Democrático (PSD), incluiu no seu projeto de modernização as camadas populares, notadamente os ex-seringueiros.

${ }^{128}$ SANTOS, José Guiomard dos. Discurso- Programa. Rio Branco: Território Federal do Acre, 1946. p. 1. 
A modernização, na sua concepção, era algo que unia, que valorizava o novo, o progresso, mas sem negar as tradições culturais e históricas das múltiplas etnias que habitavam a cidade de Rio Branco. Modernizar a "selva", não significava destruí-la, e sim desenvolvê-la, criar as bases para o progresso do Acre. Cabia ao Estado, nesse sentido, guiar e educar o povo. "[. . .] Creio no Acre e nos acreanos. Confiai, pois em mim, como eu já confio plenamente em vós. Sei que esta confiança não me faltará [. . .]. Penso, antes, no juízo desses que não sabem ouvir, e ainda não podem opinar. Trabalharei para os homens de amanhã",129

O Estado, a Igreja, a educação e a economia foram os elementos fundamentais à construção do seu projeto de modernização que contemplou sonhos e esperanças, incutiu novos valores, crenças e hábitos, porém, ao mesmo tempo, conservou as tradições do Acre.

Rio Branco na sua gestão transformou-se num "palco de obras", no entendimento de que cabia ao Estado-planejador e interventor remodelar a cidade, aformozeá-la, instituir hábitos e comportamentos aceitáveis, implementar novas atividades econômicas visando atender as demandas de emprego para os ex-seringueiros que se encontravam "vagando" pelas ruas da capital acreana, através da criação das colônias agrícolas. Era a cidade vitrine tomando forma.

Os fundamentos, pois, de "sua" invenção do Acre estavam calcados de um lado, no projeto do Estado brasileiro, do governo da União para o Território do Acre e do outro nos interesses dos sujeitos sociais que habitavam aquela localidade, nas significações presentes no seu imaginário social coletivo.

Dia virá em que o Acre, que ora serve de exemplo de descrédito, figurando na imprensa carioca e constituinte, como atestado de incúria e incapacidade, como motivo para supressão dos Territórios; dia virá em que o Acre será terra feliz e rica, capaz de servir de exemplo aos seus irmãos mais novos Ponta Porã, Iguassú, Guaporé, Amapá e Rio Branco. Não sou um poeta e sim um engenheiro-soldado. Não sou um visionário - entrevejo a hora do Acre $^{130}$.

${ }^{129}$ Ibid. p. 5 .
${ }^{130}$ Ibid. p. 4. 
E, para fortalecer a combalida economia da borracha, Guiomard Santos, como tivemos oportunidade de assinalar anteriormente, uniu esforços para o estabelecimento de uma política de valorização da borracha, no entanto, foi no governo de João Kubitscheck de Figueredo que o aludido plano foi aprovado pela Constituinte de 1946.

Por outro lado, foi no início dos anos 50 que a "chama" da luta pela autonomia voltou a brilhar com mais intensidade, só que a trincheira de embate passou a ser o Congresso Nacional, através da ação política de Guiomard Santos como deputado federal, eleito em 1951, com esta finalidade.

Internamente, apesar da precariedade de recursos financeiros, os esforços dos governos locais se concentravam em incentivar a produção extrativista e a incipiente agropecuária, melhorar os transportes e as comunicações internas, expandir a eletrificação na região, melhorar o abastecimento de combustíveis e manter e construir novas escolas na capital e no interior.

Outro aspecto a ressaltarmos é que, a partir desse período, o governo do Acre passará a ser, preferencialmente, representado por pessoas nativas do Acre ou que estejam na região a bastante tempo. O acreanismo, na sua feição política, passa a ser a tônica do dia.

Nesse sentido, a nomeação do Dr. Abel Pinheiro Maciel Filho para o governo do Acre foi entusiasticamente saudada pelas forças políticas regionais, na medida que, até então, nenhum acreano havia sido indicado pela presidência da República para governar o Acre. E o Dr. Abel Pinheiro, embora não fosse natural da região, pois era amazonense, estava radicado há 29 anos no Território, tendo sido Prefeito de Tarauacá e Cruzeiro do Sul, além de médico do Departamento de Saúde de Cruzeiro do Sul.

A esse respeito o jornal "O Acre", de 7 de junho de 1953, manifestou-se dizendo: "O Dr. Abel Pinheiro é recebido com júbilo pelo povo para o governo do Acre. A bandeira do 
acreanismo está desfraldada. O Dr. Abel, embora não seja nascido no Acre, prometeu trabalhar pelo Acre, considerava-se um acreano"

A outra nomeação importante e de impacto na região foi a do historiador Arthur César Ferreira Reis para a superintendência do Plano de Valorização Econômica da Amazônia, por ser um conhecedor profundo dos assuntos amazônicos.

Paralelamente a essas ocorrências que, embora tímidas, marcavam o início da estratégia “o Acre para os acreanos”, como perspectiva de não aceitação de governantes estranhos a região e/ou não comprometidos com este, é a partir de então, que Guiomard Santos, organicamente, passará a instrumentalizar os representantes das forças políticas locais, mormente os ligados ao PSD para fazer pressão junto ao governo da União quanto a concretização do ideal autonomista.

E, como resultado da ação consorciada entre a Superintendência de Valorização Econômica da Amazônia e o governo do Território do Acre, foram liberados recursos que propiciaram melhorias no campo da saúde (Construção do Hospital de Leprosos e continuação das obras da Santa Casa de Misericórdia), saneamento e urbanização dos municípios de Rio Branco e Cruzeiro do Sul, transportes e comunicações, preparo e aperfeiçoamento do quadro de pessoal do Território, dentre outras de menor impacto.

Por sua vez, nesse contexto, a Amazônia brasileira começa a ser reconhecida por sua importância para o desenvolvimento nacional. A constituinte de 1946, no seu artigo 199, expressa:

Na execução do Plano de Valorização econômica da Amazônia a União aplicará durante pelo menos vinte anos consecutivos, a quantia não inferior a três por cento de sua renda tributária. Parágrafo único - Os Estados e os Territórios daquela região bem como os respectivos municípios reservarão para o mesmo fim, anualmente, três por cento das suas rendas tributárias. Os recursos de que trata este parágrafo serão aplicados por intermédio do governo federal ${ }^{131}$.

${ }^{131}$ Jornal "O Acre", 25 de abril de 1954. 
Em 1954, a perspectiva que se configurava era da integração da Amazônia ao mercado nacional.

Nada nos deterá nesta arrancada que é no século XX, a mais alta tarefa do homem civilizado: conquistar e dominar os vales das grandes torrentes equatoriais, transformando a sua força cega e a sua fertilidade extraordinária em energia disciplinada. O Amazonas sob o impulso fecundo da nossa vontade e do nosso trabalho deixará de ser afinal, um simples capítulo da história da terra e, equiparado aos grandes rios, tornar-se-á um capítulo da história da civilização ${ }^{132}$.

E, por ocasião do aniversário do cinqüentenário do Tratado de Petrópolis, na sessão da

Câmara Federal de 1953, em nome da maioria, Guiomard Santos num discurso longo, carregado do simbolismo histórico da epopéia acreana, assinalou:

Correram cinqüenta anos sôbre o Tratado de Petrópolis. A monumental obra de Rio Branco já deve estar empoeirada nos arquivos do Itamarati! E o Acre! Com surpresa dos revolucionários, foi criada uma forma de governo desconhecida até então entre nós - o Território Federal - regime de colônia, anacrônico, caracterizado pela presença de um poder executivo da nomeação. Por mais que se queira "dourar a pílula" com melhoramentos materiais de vulto, estes não podem esconder a perda injustificada da autodeterminação de um povo. Custa a crer [. . .] que a partir de 1904 se tenha dividido a população do Brasil em duas categorias - a dos habitantes dos estados, no uso pleno e no gozo de todas as características de cidadania, e a dos habitantes do Acre. Estes não tinham, como ainda não têm, direitos políticos integrais. [. . .] É em tal sentido que tenho a honra de dizer ao povo brasileiro, aqui tão bem simbolizado por VV Excias, que apresentarei projeto a Câmara pleiteando para o Acre um Estatuto de Território Federal Independente. ${ }^{133}$

A representatividade e legitimidade do poder político no Acre estão em discussão. O

Acre está em discussão. O Acre exige ser Estado.

\footnotetext{
${ }^{132}$ Ibid., p.

${ }^{133}$ SANTOS, José Guiomard dos. Cinqüentenário do Tratado de Petrópolis. Discurso proferido na Sessão da Câmara Federal, em 17 de novembro de 1953, em nome da maioria. In: BEZERRA, Maria José. Dossiê - Acervo: Guiomard Santos (Acre).

Elevação do Acre a Estado. Rio Branco: Globo, 1992, p. 47 - 50.
} 


\section{CAPÍTULO 2 - A INVENÇÃO DO ACRE EMANCIPADO}

O discurso é o lugar do trabalho, da língua e da ideologia.

Eni P. Orlandi

O discurso proferido por Guiomard Santos, na condição de deputado federal, em 17 de novembro de 1953 , entre os documentos oficiais que integram a pesquisa desenvolvida para esta tese, é aquele que anuncia o início da luta pela autonomia do Acre em uma nova trincheira - o Congresso Nacional.

Utilizando os recursos da retórica e metáfora de maneira emocional, Guiomard Santos foi buscar na história acreana os elementos simbólicos capazes de persuadir o público eclético partidário e ideologicamente que o ouvia a tomar uma posição pró-autonomia do Acre.

Considerando que o discurso é a palavra em movimento e que a Análise do Discurso concebe a linguagem como mediação necessária entre o homem e a realidade natural e social, e, mais ainda, que todo dizer é ideologicamente marcado, pois é na língua que a ideologia se materializa e, sobretudo que todo discurso é também marcado pelo lugar social do referente, torna-se imprescindível contextualizarmos Guiomard Santos, pois os homens não falam apenas com palavras, textos, mas também nas instituições, práticas, técnicas e objetos que produzem.

Quem foi Guiomard Santos? De que lugar social ele nos fala?

José Guiomard dos Santos nasceu em 1907, em Perdigão (Minas Gerais). Foi engenheiro militar, com especialização em astronomia e geodésia, e exerceu várias atividades militares, tais como: membro das Comissões Demarcadores de Limites Brasil-Colômbia, membro da Comissão Brasileira Demarcadora de Limites com o Paraguai, membro da 
Comissão de Limites com o Uruguai; subchefe da Comissão de Limites com a Colômbia, Paraguai e Uruguai e governador do Território Federal de Ponta Porã (1940 - 43).

De 1946-50 foi Governador Delegado do Território do Acre e posteriormente dedicouse à vida parlamentar, sendo deputado federal pelo Território do Acre em 1951-54; 1954-58; 1958-62. Em 1962 foi eleito senador da República pelo Estado do Acre, reeleito em 1970. No ano de 1977 foi escolhido indiretamente para o Senado.

Produziu vários textos na área de ciências humanas, recebeu várias condecorações, foi membro do Instituto Histórico e Geográfico do Estado do Amazonas, da Sociedade de Geografia (Rio de Janeiro) e do Clube de Engenharia (Rio de Janeiro).

Membro ativo do Partido Social Democrático (PSD), foi um liberal conservador que na sua prática defendia a educação formal e política do povo acreano, segundo ele, povo heróico, porém inculto, simples, primitivo, ingênuo e natural que devia alcançar a consciência democrática sob a tutela do Estado. Foi também autor do Projeto-lei para elevação do Acre a Estado. Morreu em 1983, aos 76 anos, como senador "biônico".

Frente ao exposto, no aludido documento buscamos entender o interdiscurso como aquilo que fala antes, em outro lugar, independentemente. O interdiscurso disponibiliza dizeres que afetam o modo como o sujeito significa em uma situação discursiva dada.

Importante ainda destacarmos que dizer não é "propriedade particular. As palavras não são nossas. Elas significam pela história e pela língua. O que é dito em outro lugar também significa em "nossas" palavras"134.

Existe, portanto, uma relação entre o já dito e o que se está dizendo, que é a que existe entre o interdiscurso e o intradiscurso ou, em outras palavras, entre a constituição do sentido e sua formulação "[ . . . Todo dizer na realidade se encontra na confluência de dois eixos: o da

${ }^{134}$ ORLANDI, Eni P. Análise de discurso: princípios e procedimentos. p. 32. 
memória (constituição) e o da atualidade (formulação). E é desse jogo que tiram seus sentidos"135.

Nessa perspectiva, o discurso de Guiomard Santos nos remete ao contexto da luta dos patrões-seringalistas pelas terras do Acre, sendo este, em um outro tempo e lugar, porta-voz do ideário emancipacionista daqueles. Por outro lado, ao se dirigir ao Congresso Nacional, Guiomard Santos, conhecedor do poder da palavra, fez uso dos simbolismos da epopéia acreana para dominar, convencer e persuadir os seus pares congressistas quanto a legitimidade do movimento pró-autonomia do Acre. Instrumentalmente visava este criar um clima favorável à discussão do projeto de elevação do Acre a Estado que enviaria à Câmara Federal no ano seguinte (1954).

2.1 - O Acre quer ser Estado

Em cinqüenta anos não preparamos o Acre nem para uma economia estável, nem para as franquias democráticas.

José Guiomard dos Santos

Corporificando o ideal de emancipação do Acre, Guiomard Santos apresentou em 1954, à Câmara Federal, a primeira versão do projeto de elevação do Acre a Estado, cuja síntese era a seguinte:

Eleva à categoria de Estado o Território do Estado do Acre

Art. $1^{\circ}$ ) Por esta lei especial, o Território do Acre, tal como se acha atualmente constituído, é elevado à categoria de Estado-membro da Federação, com o nome de Estado do Acre.

Parágrafo único - Um ano depois de publicada a presente lei, todas as providências e atos dela decorrente, hão de ter sido cumpridos pelas autoridades representativas dos poderes da União e do novo Estado.

${ }^{135}$ Ibid., 32-33. 
Art. $2^{\circ}$ ) As dotações orçamentárias federais destinadas ao Território, serão mantidas a título de auxílio ao Estado tomando-se por base o exercício de 1954.

Parágrafo $1^{\circ}$ - A medida que a arrecadação do Acre crescer o auxílio de que trata o artigo $2^{\circ}$ poderá ir sendo reduzido, anualmente, na mesma proporção, até alcançar paridade com as despesas federais realizadas no Estado em que for menor a soma dessas despesas.

Parágrafo $2^{\circ}$ - Para o disposto no parágrafo anterior, considerar-se-á com o caráter de auxílio, todas as verbas orçamentárias e quotas distribuídas por intermédio dos Ministérios ou de entidades oficiais para aplicação nos Estados.

Parágrafo $3^{\circ}$ - Em caso em que o Acre venha a tributar a sua borracha, levar-se-á a efeito aumento correspondente, e concomitante, do preço de compra dêsse produto, a ser estabelecido pelos órgãos federais competentes. Art. $3^{\circ}$ ) A Justiça eleitoral promoverá eleições no Território do Acre, a fim de que uma assembléia legislativa, composta de 20 representantes, promulgue a Constituição do Estado, dentro do prazo de que trata o parágrafo único do art. $1^{\circ}$.

Sala das Sessões da Câmara dos Deputados, em junho de $1954^{136}$

A partir desse momento, a luta pró-autonomia do Acre ganha espaço na imprensa nacional, seja através de artigos assinados por Guiomard Santos ou por outro membro do Comitê Pró-autonomia do Acre, ou, ainda, por simpatizantes da causa autonomista no Território ou fora deste.

Mas, o fato é que os contextos brasileiro e internacional em que este documento se insere são marcados pela presença expressiva dos E.U.A, na medida que foi nos anos 50 que “Tio Sam chega ao Brasil”, utilizando várias estratégias econômicas, políticas e culturais de forma contundente, se coloca tanto no discurso quanto na prática defensor da democracia no hemisfério sul frente à expansão de "ideologias exóticas".

E, neste sentido, é importante considerarmos que pós Segunda Guerra Mundial consolidou-se a hegemonia econômica norte-americana num universo caracterizado pela “Guerra Fria". Frente a esse fato, a disputa política e ideológica entre os E.U.A e a extinta URSS por áreas de influência e os envolvimento destes nos conflitos mundiais localizados passaram a ser a prática da política externa destas duas potências mundiais.

\footnotetext{
${ }^{136}$ SANTOS, José Guiomard dos. Projeto de Lei Especial. In: BEZERRA, Maria José. Dossiê - Acervo: Guiomard Santos (Acre) Elevação do Acre a Estado, p. 52.
} 
Dessa forma compreende-se que Guiomard Santos tenha justificado a autonomia acreana fazendo uso do discurso democrático numa conjuntura brasileira em que as elites nacionais conservadoras "temiam" pela democracia frente aos rumos da Presidência de Getúlio Vargas. Embora não o explicite. Estava no silêncio. E o silêncio é fundante no discurso. O silêncio fala. . .

Convenci-me através da convivência com dois Territórios Federais, de que esse sistema de govêrno, em vez de ser desejável de caminhar para a democracia, ao contrário, conduz às fórmulas totalitárias, senão ao conformismo ou aceitação dos seus princípios. Quanto a isto não há como negar. É a tendência dos governos fortemente centralizados. [. . .] O fato de não defender o seu cargo, o povo a cuja frente se encontra, e sim, e somente do Presidente da República, sempre ausente e tão distante, tudo enfim estimula e convida a prepotência e arbitrariedades de todo gênero ${ }^{137}$.

Na condição de orgânico da causa autonomista, desde 1953, Guiomard Santos passou a instrumentalizar os representantes das forças políticas locais ensejando a formação de um “bloco pró-autonomista”. E são os membros deste que através da imprensa, abaixo-assinados, correspondências particulares, telegramas, relatos de debates, entre outros, mantinham-no informado dos rumos da luta pró-autonomista no âmbito do Território.

Por outro lado, considerando-se as diferenças geográficas e sobretudo as divisões entre as forças políticas regionais, a causa autonomista não "incendiou” o Acre na mesma proporção. O Vale do Juruá, em documento assinado pelo jornalista João Mariano, através do jornal "O Juruá", após ponderar sobre as peculiaridades dos vales do Acre e Juruá, enfatiza que os governos territoriais só investiam em Rio Branco por ser capital e nos municípios vizinhos a este -, inclusive, o próprio Guiomard Santos quando foi governador territorial. Dessa forma, a causa autonomista não "empolgava” o povo do Juruá frente ao contexto de miséria material em que estava inserido.

${ }^{137}$ BEZERRA, Maria José. Dossiê - Acervo: Guiomard Santos (Acre) Elevação do Acre a Estado, p. 53. 
Feito o Estado, o governador será eleito, mas, que adiantará isso ao Juruá, se pelo seu analfabetismo, pela falta de líderes, pelo seu insignificante eleitorado, nada poderá fazer que faça convergir para os seus direitos os favores dos detentores da política acreana. Queremos adiante eleger um Prefeito se esse Prefeito quiser fazer alguma coisa por êste povo terá que "tirar-lhe o couro" através de pesados impostos? [. . .] Até agora aqui na cidade, somente duas pessoas vi favorável ao seu projeto. [. . . ] Eu prevendo que o Estado nada trará que possa beneficiar aquele povo, acho que o meu amigo devia patrocinar a causa da divisão, e se ver que o Vale do Acre, onde se encontram casos dessa natureza, está em condições de ser um Estado autônomo, que o seja o lado de lá e o de cá se constitua em Território, para que possa usufruir aquilo que o outro lado já obteve e, então, quando possível, far-se-á o Estado do Juruá ${ }^{138}$.

Em artigo também datado de 3 de março de 1957, com o apoio das autoridades e representantes das "classes conservadoras", denominado "autonomia do Acre", o Jornal "O Juruá" argumenta que Rio Branco e os demais municípios do Vale do Acre concentravam os investimentos públicos, enquanto o Vale do Juruá encontrava-se mergulhado num quadro de penúria absoluta.

O Vale do Juruá não está em condições de fazer parte do Estado autônomo do Acre, pois além da falta de vida própria, há a encarar o fator capital: de todos os proprietários e comerciantes do Juruá, somente um, o sr. Raimundo Quirino Nobre está em condições de carregar, por duas vezes ao ano, um navio de quatrocentas toneladas de mercadorias, em Belém para os seus armazéns nesta cidade. Isso indica a pobreza da região. [. . . ] Faça-se o Território do Juruá. Incentiva-se a sua lavoura e pecuária, organizem-se algumas pequenas indústrias, extraia-se o petróleo do Moa, eis o caminho a seguir" ${ }^{\prime 139}$.[ Grifos nossos]

A oposição, representada pelo deputado federal Oscar Passos, líder do Partido Trabalhista Brasileiro (PTB), também advogava e se colocava contra o projeto de elevação do Acre a Estado por considerá-lo eleitoreiro, pois o Território não possuía sustentação econômica.

Não há quem de boa fé, possa ser contrário á autonomia dos Territórios brasileiros, aspiração máxima - e mais justa — dos seus habitantes e objetivo que encontra guarida na própria constituição. [. . . dirigir a sua própria vida, resolver os seus problemas e decidir sobre os rumos políticos e econômicos que mais lhes convém é um direito que não deve ser recusado aos brasileiros dos Territórios. No caso especial do Acre, com mais forte

${ }^{138}$ SILVA, João Mariano da. Carta ao Guiomard Santos. 3 de março de 1957.

${ }^{139}$ O Juruá. Autonomia do Acre. 3 de março de 1957. 
razão, é de reconhecer a urgência da solução, já pela experiência dolorosa porque tem passado as suas populações, submetidas a tirania do capricho, do interesse político ou não da incompetência de administradores alienígenas, que lhe são impostos, já por se tratar do mais antigo Território. Neste último aspecto é de levar em conta - e não olvidar - que os brasileiros do Acre demonstram, há mais de meio século, capacidade, decisão e bravura para repelir violentamente a dominação estrangeira. Se estas qualidades tivessem sido convenientemente aproveitadas e orientadas na paz, como o foram na guerra, já o Acre, por sem dúvida, estaria a brilhar na constelação dos Estados brasileiros, rico e próspero, hospitaleiro e feliz. Não houve este cuidado por parte de muitos dirigentes, impuseram-lhes o garrote da dominação dos homens pelos homens. Um feudo foi o que resultou de tanta bravura e esforço. No Acre, afora a atividade nos seringais, profundamente dispersa e, por isso mesmo, sujeita a regras e costumes eminentemente locais, e do comércio, de cunho quase inteiramente familiar, pobre e insuficiente [. . .] Não há indústrias, não há atividades particulares.

A corrida para o emprego público, estimulada pelos detentores do poder é, portanto, normal e imperiosa. [. . .] Acorrentados ao governo pela inevitável dependência econômica dificilmente poderão essas populações manifestar livremente a sua preferência política ou sequer a sua opinião sobre os detentores do poder local. [. . .] Politicamente o Acre e sua população nada lucrariam. [. . .] A eleição do governador e da Assembléia Legislativa seria uma farsa [. . . No momento presente como é público, a União entrega ao Acre mais de 300 milhões de cruzeiros por ano e arrecada, através das Mesas de Renda e Coletorias apenas 3 ou 4 milhões. Com a emancipação do Território, a União não fornecerá mais essas verbas. [. . .] Os 300 milhões terão que ser arrancados do próprio povo acreano. ${ }^{40}$ [Grifos nossos].

Com base nos princípios do pensamento político liberal, Oscar Passos faz a "sua" crítica ao projeto de elevação do Acre a Estado. Evidente que a mesma é pertinente em muitos aspectos pelo que temos apresentado até o presente neste trabalho.

Em primeiro lugar, nos anos 50, com a crise da borracha pós-guerra, o Acre dependia quase que inteiramente dos recursos financeiros do governo federal, sendo o governo, como ainda é na atualidade, o maior empregador. Porém, embora o projeto do Guiomard Santos tenha sido gestado de cima para baixo, este buscou o referendo popular a partir da compreensão de que cabia aos representantes do poder político "guiar e instruir o povo". Este era o papel do intelectual, do Estado, das instituições. A sua visão ideológica e política não admitia o conflito. A sociedade deveria ser harmônica e integradora. 
Por outro lado, não se pode pensar que o povo, as camadas populares, constituem-se numa massa amorfa, que é manipulada pelo poder político institucionalizado segundo o seu bel-prazer.

Marilene Chauí, no livro "Conformismo e Resistência - aspectos da cultura popular no Brasil", assinala que, dependendo do contexto, o povo se conforma resistindo e resiste se conformando. Há formas as mais diversas de resistências, não apenas as organizadas e coletivas.

No caso específico do Acre, a elevação a Estado significaria naquela conjuntura a possibilidade de viabilizar um projeto de desenvolvimento para a região, embora formulado e gestado de fora para dentro. No entanto, nas suas "brechas" poderia haver algum avanço. Além da questão da autodeterminação dos povos, o Estado implicaria a constituição de uma representação política local, na possibilidade da formulação e execução de projetos voltados para os interesses da região e na ascensão de representantes políticos locais a estrutura do poder político, como de fato ocorreu com a eleição do jovem cruzeirense, professor e exmilitante da UNE José Augusto de Araújo para o cargo de primeiro governador do Acre constitucional, apesar da feudalização da administração pública e do clientelismo político.

Em 1957, Guiomard Santos, já incorporando ao projeto anterior as discussões que se processaram de 1954 a 1957, no âmbito do Congresso Nacional e fora deste, reapresenta-o com o seguinte formato:

Eleva o Território do Acre a categoria de Estado e dá outras providências.

O Congresso Nacional decreta:

Artigo $1^{\circ}$ ) - Por esta lei especial, o Território do Acre, tal como se acha atualmente constituído, é elevado à categoria de Estado-membro da Federação, com o nome de Estado do Acre.

${ }^{140}$ PASSOS, Oscar. Considerações sobre a autonomia do Território do Acre. In: BEZERRA, Maria José. Dossiê - Acervo: Guiomard Santos (Acre). Elevação do Acre a Estado. Rio Branco: Globo, 1982, p. 61-65. 
Parágrafo único - um ano depois de publicada a presente lei, tôdas as providências e atos decorrentes da mesma hão de ter sido cumpridos pelas autoridades representativas dos poderes da União e do novo Estado.

Artigo $2^{\circ}$ ) - A Justiça Eleitoral providenciará para que uma assembléia composta de 20 representantes promulgue a Constituição do Estado dentro do prazo de que trata o parágrafo único do artigo $1^{\circ}$.

Artigo $3^{\circ}$ ) - As verbas orçamentárias destinadas ao Território do Acre serão mantidas como auxílio a sua administração e em caráter de emergência.

$\S 1^{\circ}$. Tal auxílio terá como base o exercício financeiro em que se constitui o novo Estado, vigorando durante período de transição de um lustro.

$\S 2^{\circ}$. Em caso de aumento de rendas do Acre, a quota federal de que trata esta lei poderá ser reduzida anualmente, até atingir paridade com as despesas da União, no Estado em que for menor a soma das ditas despesas. $\S 3^{\circ}$. Para o disposto no parágrafo anterior, considerar-se-á como auxílio todas as dotações distribuídas pelos Ministérios ou órgãos federais em cada Estado.

Artigo $4^{\circ}$ ) - Passarão para a jurisdição do Estado os serviços e bens a cargo do Território, ou do Governo Federal, obedecendo o que dispõe a Constituição e as leis.

$\S 1^{\circ}$. As autoridades judiciárias, serventuários da União, funcionários e extranumerários territoriais continuarão em exercício, por conta da União, até que sejam substituídos pelos que forem eleitos pelo povo, nomeados, ou designados, pelo governo do Estado.

$\S 2^{\circ}$. A substituição far-se-á mediante entendimento entre os respectivos governos, sem prejuízo dos serviços, e uma vez efetivados, o pessoal de que trata o parágrafo anterior será posto em disponibilidade, de acordo com a legislação vigente.

Sala das Sessões da Câmara de Deputados ${ }^{141}$

Analisando as duas propostas (1954 e 1957) de projetos de lei referentes à elevação do Acre a Estado, observamos que as alterações de fato foram mínimas, porém de grande significação e impacto, além de "responderem" as principais críticas produzidas pelos opositores quanto à incapacidade orçamentária que teria o Acre para se manter como Estado.

Por outro lado, fazendo uma análise comparativa dos conteúdos dos aludidos Projetos de Lei, observamos que o de 1954 é constituído de três artigos, não possui o evocativo “Congresso Nacional” presente na versão de 1957, seu parágrafo único é igual ao de 1957 e não possui o artigo $4^{\circ}$.

${ }^{141}$ SANTOS, José Guiomard dos. Projeto de elevação do Acre a Estado (versão de 1957). In: BEZERRA, Maria José. Dossiê - Acervo: Guiomard Santos (Acre) Elevação do Acre a Estado, p. 90-91. 
Nos demais casos, a proposta de 1957 reproduz a de 1954, mudando apenas de posição vários parágrafos e/ou fazendo pequenas alterações redacionais, quais sejam: o artigo $3^{\circ}$ de 1954 é ao artigo $2^{\circ}$ de 1957; no artigo $2^{\circ}$, o primeiro parágrafo é igual ao $2^{\circ}$ parágrafo do artigo $3^{\circ}$ de 1957; o artigo $3^{\circ}$ de 1957 não existe em 1954; o parágrafo $2^{\circ}$ de 1954 é igual ao parágrafo $3^{\circ}$ de 1957; e o artigo $3^{\circ}$ de 1954 é igual ao artigo $2^{\circ}$ de 1957 . Fica, portanto, evidente que o de 1957 se constitui uma proposta mais completa, assinada não apenas por Guiomard Santos, mas por um número expressivo de parlamentares, o que denota a capacidade de articulação política do Guiomard Santos em termos nacionais. Eis os congressistas que assinaram:

Vasconcelos Costa - Godoy Ilha - Hermes Pereira de Souza - Sylvio Sanson - Cezar Prieto - Nestor Pereira - Joaquim Duval - Coelho de Souza - Nestor Jost - Daniel Dip - Daniel Faraco - Clóvis Pestana - Aarão Stembruch - Otávio Mangabeira - Fernando Ferrari - Tarso Dutra - Luiz Compagnon - Lino Braum - Raul Pilla - Onório Machado - João Fico Maurício Andrade - Philadelpho Garcia - Souto Maior - Guilherme de Oliveira - Pereira da Silva - Último de Carvalho - Rocha Loures - Laurínio Regis - Otacílio Negrão - Leônicas Cardoso - Wilson Fadul - Amaury Pedrosa - Heráclito Rego - Badaró Júnior - Marcos Parente - Dias de Araújo - Armando Falcão - Leonardo Barbieri - Lerner Rodrigues - (nome ilegível) - Victorino Correa - Arino de Mattos - Marians Rodrigues Taciano de Melo - Nicanor Silva - Madeiros Netto - Fonseca e Silva Joaquim Rondon - Chagas Rodrigues - Abguar Bastos - Oscar Carneiro Guilherme Machado - Dagoberto Salles - Coaracy Nunes - Renato Archer - França Campos - Yukishigue Tamura - Adahil Barreto - Aurélio Vianna - Feliz Vlois - Segadas Viana - Mário Gomes - Colombo de Souza - José Joffily - Oliveira Franco - Rondon Pacheco - José Talarico - Plínio Lemos - Cid Carvalho - Frota Aguiar - Janduhy Carneiro - Pacheco Chaves Hugo Napoleão - Vieira de Mello - Saturnino Braga - Napoleão Fontenelle - Cícero Alves - Sérgio Magalhães - Lopo Coelho - Euclides Wicar Saldanha Derzi - Milton Brandão - Willy Frohlic - Leoberto Leal Newton Bello - Salles Filho - Ranieri Mazzili - Nonato Marques - Chagas Freitas - Ari Pitombo - José Bonifácio - Esteves Rodrigues - Gabriel Hermes - Getúlio Moura - Geraldo Mascarenhas - Nestor Duarte Oliveira Britto - Eduardo Catalão - Sigefredo Pacheco - Vasco Filho Benedito Vaz - Afonso Matos - Freitas Diniz - José Guimarães Raimundo Padilha - Danton Coelho - Croacy de Oliveira - Bias Fortes Georges Galvão - Nogueira da Gama - Wanderley Júnior - Ernesto Sabóia - Oceano Carleral - Dias Lins - Oswaldo Lima Filho - Bruzzi Mendonça Campos Vergal - Portugal Tavares - Newton Carneiro - Cunha Machado Waldemar Rupp - Ponciano dos Santos - José Pedroso - Drayle Ernany Manoel Barbusa - Riça Júnior - Odiolon Braza - Castilho Cabral - Rafael Corrêa - Carlos Luiz - Josué de Souza - Uriel Alvim - Theodorico Bezerra 
- Dix-Huit Rosado - Milton Campos - Dilermando Cruz - Nogueira de Rezende - Gudgei do Amaral - Benjamin Farah - Pereira Lima - José Arnaud - Djalma Marinho - Gabriel Passos - Neiva Moreira - João Machado - Antônio Maia - Rogê Ferreira - Paulo Freire - Luís Tourinho Cid Campelo - Ruy Santos - Lima Cavalcanti - Bilac Pinto - João Menezes - Barsílio Machado - Celso Murta - Armando Monteiro Horácio Lafer - Herbert de Castro - Divosir Cortes - Arruda Câmera Chalbaud Biscaia - Antônio Baby - Frota Moreira - Barros Carvalho Júlio Castro Pinto - José Fragelli - Ilacir Lima - João Agripino - Pereira Diniz - Jaeder Albergaria - Alencar Araripe - Nelson Monteiro - Correa da Costa - Plínio Ribeiro - Mário Martins - Antônio Dino - Magalhães Pinto - Aloísio de Castro - Carlos Albuquerque - Mário Guimarães - Aziz Maron - Antunes de Oliveira - Roxo Loureiro - Olavo Costa - Lycurgo Leite - Menotti del Picchia - Arnaldo Cerdeira - Menezes Pimentel Fiman Neto - Barcelos Feio - Carvalho Sobrinho - Celso Peçanha - Nelson Parijós - Virgínio Santa Rosa - Leite Neto - Mendes Gonçalves - Dantas Júnior - Clemente Medrado - Moreira da Rocha - Ovídio de Abreu Adolfo Gentil - Antônio Horácio - Loureiro Júnior - Hermógenes Príncipe - Mendonça Braga - Armando Lages - Cardoso de Menezes - Broca Filho - Nelson Omegna - Elias Adaime - Augusto Viana - Augusto Publico Luiz Viana - Carlos Pinto - Luís Garcia - Francisco Macedo - Nita Costa Bento Gonçalves - Aliomar Baleeiro - Ivan Bichara - João Ursulo - Pedro Braga - Monteiro de Barros - Lister Caldas - Alberto Torres - Lourival Fontes - Carlos Jereissati - Armando Corrêa - Lameira Bittencourt ${ }^{142}$.

A tramitação do projeto de lei de 1957, sob o número 2.654/57, no Congresso Nacional teve início em 6 de novembro, às quinze horas, na sala Afrânio de Melo Franco, quando na sessão ordinária, reuniu-se a Comissão de Constituição e Justiça, sob a Presidência do Deputado Federal, Nogueira da Gama e contando com as presenças dos deputados Tarso Dutra, Rondon Pacheco, Paulo Germano, Abguar Bastos, Antônio Horácio, Prado Kelly, Milton Campos, Armando Rollemberg, Joaquim Duval e Pereira Filho, tendo como relator o deputado Tarso Dutra, que após analisar o referido processo emitiu parecer acerca da constitucionalidade do mesmo em três emendas.

As emendas propostas consistiam em:

"Emenda n" 1

suspensão do parágrafo único do artigo $1^{\circ}$.

Emenda $n^{\circ} 2^{\circ}$

Nova redação para o artigo $2^{\circ}$ nos seguintes termos:

${ }^{142}$ KALUME, Jorge. Elevação do Território do Acre à Estado. Brasília. Senado Federal, 1985, p. 102-103. 
A Justiça Eleitoral fixará dentro de dois meses após a promulgação da presente lei a data das eleições de governador e de deputados à Assembléia Legislativa, os quais serão em número de dez (10) e terão, inicialmente, funções constituintes.

Emenda $n^{\circ} 3^{\circ}$

Redijam assim os $\S 1^{\circ}$ e $2^{\circ}$ do artigo $4^{\circ}$.

$\left.\S 1^{\circ}\right)$ As autoridades judiciárias, serventuários de justiça e demais servidores territoriais continuarão em exercício, por conta da União, até que sejam substituídos mediante investidura legal, pelos órgãos próprios da organização constitucional do Estado.

$\S 2^{\circ}$ ) Efetivada essa substituição, os servidores públicos, intitulados de estabilidade legal e os magistrados e titulares de ofícios de justiça serão postos em disponibilidade de acordo com a legislação vigente, até serem aproveitados em outras funções equivalentes por sua natureza e estipêndios. ${ }^{143}$.

A partir de então, a questão da elevação do Acre a Estado ganha amplitude nos jornais nacionais e locais, nestes últimos com destaque para as publicações de "O Acre" e "O Estado", em artigos assinados na sua maioria pelos membros do Comitê Pró-Autonomia do Acre, a saber: Dr. Omar Sabino, Geraldo Gurgel de Mesquita, o próprio Guiomard Santos, Edison Martins, Ivo Aguiar, Alfredo Mubárac, Natal de Brito, Elzo Rodrigues, Rubens Carreira, Nemésio de Carvalho, Otacílio Costa, Darci Fontenele, entre outros.

Pelo Estado do Acre segundo despacho telegráfico do nosso correspondente na capital da República, os deputados amazonenses Antonia Maia e Pereira da Silva, do PSD, Rica Júnior, Aureo Melo, José Cláudio de Sousa e Manoel Barbuda, do PTB assinaram o Projeto [. . .] entre os nomes mais expressivos que assinaram o referido Projeto estão os do General Flores da Cunha e do vice-presidente da Câmara e mais os deputados gaúchos: Sílvio Sansou, César Prietro, Fernando Ferrari, Coaraci Oliveira, Omínio Machado do PTB. Joaquim Durval, Daniel Faraco, Nestor Jost Clovis Pestana do PSD. Além de Raul Pila do Libertador e que lidera o movimento parlamentarista. Também os deputados Joaquim da Silva Rondon, do Território de Rondônia, Coaracy Nunes do Território do Amapá e Félix Valois, do Território do Rio Branco[... . $]^{144}$.

Através dos jornais "O Estado" - criado com a finalidade de divulgar notícias, artigos e abaixo-assinados em prol da causa autonomista -, ou "O Acre" - jornal oficial mais antigo

${ }^{143}$ KALUME, Jorge. Elevação do Território do Acre a Estado. Brasília: Senado Federal, 1985, p. 116-117.

${ }^{144}$ O Acre, 10 de março de 1957, p. 1. 
do Acre, membros do Comitê Pró-Autonomia do Acre instrumentalizados por Guiomard Santos mantinham acesa a "tocha da liberdade no Acre".

Ele [o projeto] representa um compromisso assumido com o nosso povo pelo incansável parlamentar, que percorreu todos os quadrantes do Território, em 1954, em defesa de nossa autonomia; que baseou a sua campanha eleitoral na idéia que agora se consubstancia no patriótico projeto que vem recebendo o mais franco e decidido apoio de grande maioria dos parlamentares brasileiros ${ }^{145}$.

Considerando a capacidade de penetração do rádio, os membros do Comitê PróAutonomia do Acre também fizeram uso dos microfones da rádio Difusora Acreana, “A Voz da Selva", tanto para fazer chegar aos municípios do interior as notícias acerca do andamento do projeto de elevação do Acre a Estado quanto para rebater as críticas feitas a este ou, ainda, para conseguir adesões.

A prática das reuniões com os mais diversos segmentos da sociedade acreana para sensibilizá-los e tê-los como defensores do projeto também se tornou comum, além da elaboração e divulgação de manifestos, desde 1956.

Em reunião ante-ontem à noite na sede do Rio Branco Futebol Clube com os estudantes secundaristas ficou aceito que o Comitê Pró-Autonomia vai dirigir ao povo um manifesto em que exporá os seus objetivos gerais, assim sintetizados:

I - defender a autonomia do Acre, independente da política partidária zelando pela conservação das bases em que está redigido o Projeto já de conhecimento público; II - ter sempre em mente que o ídolo dos acreanos, Plácido de Castro e seus comandados, ao lutarem para que nosso território fosse Brasil, com a denominação de Estado do Acre, outra intenção não tiveram senão torna-nos iguais em direitos e deveres, aos demais cidadãos brasileiros; II - nunca esquecer, mesmo em debates pró-causa abraçada, que os princípios insertos na Carta Magna referendam a luta; Vhomenagear os homens que no passado fitaram o objetivo que para a geração atual parece mais próximo; concretizado esse justo e elevado ideal dos acreanos, não esquecer, mesmo em extrema dificuldade, que, desprezando interesses pessoais, lutamos por ele e, por conseguinte, cabemnos a grande responsabilidade de zelar pelos destinos do Estado, em quaisquer circunstâncias ${ }^{146}$.

${ }_{146}^{145}$ MESQUITA, Geraldo. O Acre, 17 de março de 1957.

$146 \ldots$ O Acre, 5 de maio de 1956. 
No texto acima, destaca-se o espírito de "falange" ou "legião" que os adeptos do movimento deveriam encarnar.

O caráter cívico, patriótico, ético era outro ponto de destaque nos textos veiculados pelo Comitê Pró-Autonomia.

Acre livre e Brasil mais independente.

Conterrâneos de coração, saímos do berço desassobradamente e aceleramos os nossos passos em busca de uma bandeira de liberdade para nossa terra, que é minha e que é tua. Saibamos honrar os méritos daqueles que tombaram pela independência deste rincão, num ardil golpe sem medirem conseqüência e desprendidos de paixões materiais [. . .] por um Acre livre, num Brasil mais independente. ${ }^{147}$

Em 1958, os debates tornaram-se mais aguerridos, pois a oposição ao projeto de

Guiomard Santos, capitaneada por Oscar Passos, líder do PTB local, passou também tanto na

imprensa local e nacional quanto no Congresso Nacional a disseminar críticas contundentes

ao dito projeto, inclusive como porta-voz da Associação dos Seringalistas do Acre.

Quem conhece o Território, ou quem o visita com o objetivo sincero de investigação, sente de pronto, a impossibilidade em que ele está de abrir mão, no momento da ajuda federal, ainda precária e mal empregada no desenvolvimento do progresso, para viver a própria custa, arrancando do povo o necessário à alimentação da máquina administrativa. Seria o mesmo que lançar à rua um filho de 10 anos e deixar que ele consiga o próprio sustento [.. . ] Acabo de receber da mais prestigiosa associação de classe do Território do Acre, daquela que representa o único sustentáculo econômico da região, um telegrama, verdadeiro grito angustioso ante o perigo que ameaça a todos. Deputado Oscar Passos - Rio Branco, 20 de março de 1958. A Associação dos Seringalista do Território do Acre, única classe produtora local e que há oitenta anos desbravou este território e vem lutando para o engrandecimento parque industrial $\mathrm{vg}$, vem muito respeitosamente protestar perante Vossência contra o projeto apresentado na Câmara Federal vg, qual pretende transformar este Território em Estado autônomo ou subvencionado pt. [. . .] apela Vossência se digne evitar se consuma clamoroso atentado virá estabelecer desordem vida econômica deste Território vg, mormente com a criação de impostos estaduais, além dos já existentes pt. Classes industrial e comercial deste Território já pagam impostos federais e municipais que se elevam anualmente [. . .] Povo acreano bendirá nome de Vossência se evitar que inoportuno projeto seja $\operatorname{aprovado}^{148}$.

${ }^{147}$ VITAL, Raimundo Sales. Exortação cívica. O Acre. 19 de maio de 1957.

${ }^{148}$ KALUME, Jorge. Op. cit. p. $125-126$. 
No bate-rebate de argumentos pró e contra, Guiomard Santos apresenta o documento enviado pela Sociedade Beneficente dos Operários de Rio Branco favorável ao seu projeto.

Sociedade Beneficente Operários de Rio Branco por intermédio sua atual Diretoria, tem imensa satisfação de cumprimentar ilustre cidadão e grande amigo do Acre [. . .] queremos significar Vossência nossa irrestrita solidariedade projeto autonomia do Acre, ora em tramitação Congresso Nacional; passo decisivo para nossa independência econômica dentre em breve $^{149}$.

Retomando o uso da palavra, Oscar Passos denuncia o uso da máquina administrativa do Território pelo PSD como instrumento de propaganda política, coerção social e mandonismo político. De forma imperativa, assegura que só os que não dependiam do governo podiam expressar livremente suas idéias acerca do projeto - no caso, seringalistas e seringueiros. Para fundamentar suas afirmações, lê o telegrama recebido da Associação de Seringueiros do Acre.

A Associação dos Seringueiros do Território Federal do Acre vem protestar perante Vossência contra o projeto de transformação deste Território em Estado autônomo subvencionado ora transitando pelas duas casas do Congresso Nacional pt. Esta associação dos trabalhadores da indústria extrativa da borracha vg única indústria com que conta este Território vg já em dificuldades pelo alto custo de vida e falta de assistência social vg cuja indústria não poderá arcar com mais impostos estaduais em perspectiva a serem criados vg vindo talvez aumentar desemprego nos seringais vg prejudicar produção da borracha pequeno sustentáculo do Território e também indústria nacional artefatos[... $]^{150}$.

$\mathrm{Na}$ seqüência burocrática da Câmara Federal, o projeto de elevação do Acre foi submetido à apreciação da Comissão de Finanças em 1 de julho de 1958, tendo como relator o deputado Chalbaud Biscais, que solicitou uma audiência do Ministério do Interior e Justiça para o projeto em tela.

\footnotetext{
${ }^{149}$ KALUME, Jorge. Op. Cit. p. 125 - 126.

${ }^{150}$ Ibid., p. $130-131$.
} 
No ano seguinte, 1959, o projeto continuou ainda no âmbito da Comissão de Finanças, porém, com um novo relator, Jayme Araújo, que solicitou também audiência do Ministério de Justiça e Negócios Interiores e do Instituto Brasileiro de Geografia e Estatística, tendo por base as seguintes ponderações:

Ao Ministério da Justiça e Negócios Interiores encaminhou as seguintes indagações:

I) Quais os tributos oriundos de competência estadual, cobrados no Território Federal do Acre e quais as suas incidências?

II) Quais os valores das receitas ânuas de cada um deles, no último qüinqüênio?

III) Estão os produtos extrativos ou agrícolas do Território isentos de algum ou alguns tributos de competência estadual? Em caso afirmativo, quais?

IV) Qual a despesa anual da União nesse Território Federal, no último qüinqüênio, relativa aos atos de competência estadual?

V) Qual, no referido período, o valor das dotações orçamentárias efetivamente recebidas, por conta das verbas da SPVEA, relativas aos mesmos atos?

VI) Qual o global da receita prevista e da despesa autorizada da União para o Acre, relativa aos atos de competência estadual, no corrente exercício? Idem, idem, na proposta orçamentária para o próximo ano ${ }^{151}$.

E ao Instituto Brasileiro de Geografia encaminhou cinco perguntas, a saber:

a) Qual a população estimada do Território Federal do Acre em 1 de janeiro do corrente, considerando separadamente se possível as dos Municípios das bacias dos rios Juruá e Purus?

b) Qual vem sendo a taxa anual de crescimento da população do Território?

c) Qual o valor e o peso da exportação anual do Acre no último qüinqüênio, discriminando-as pelos seus diversos produtos?

d) Qual a importação anual do Território do último qüinqüênio (peso e valor)?

e) Qual a produção anual do Acre no último qüinqüennio (peso e valor), considerando, se possível, separadamente, os municípios das bacias do Purus e do Juruá? ${ }^{152}$

Incorporando no seu parecer às alterações anteriores e com base nos documentos recebidos dos órgãos solicitados, Jayme Araújo apresenta um novo substitutivo ao projeto em

${ }^{151}$ Ibid., p. 131

${ }^{152}$ Ibid., p. 131 
29 de março de 1960 , que foi aprovado em $1^{\circ}$ de dezembro do mesmo ano, com o seguinte

teor:

Eleva o Território do Acre à categoria de Estado e dá outras providências.

O Congresso Nacional decreta:

Art. $1^{\circ}$. O Território do Acre, em seus atuais limites, é erigido em Estado do Acre.

Art. $2^{\circ}$. A Justiça Eleitoral fixará, dentro de três meses após a promulgação da presente lei, a data das eleições de Governador e de deputados à Assembléia Legislativa, os quais serão em número de quinze e terão inicialmente funções constituintes.

$\S 1^{\circ}$. A Assembléia Legislativa reunir-se-á dentro de dez dias da diplomação, sob a direção do Presidente do Tribunal Regional Eleitoral do Estado, por convocação deste e elegerá a sua Mesa.

$\S 2^{\circ}$. Se dentro de quatro meses após a instalação da Assembléia não for decretada a Constituição Estadual, o Acre adotará a do Estado vizinho (Amazonas), até que a reforme pelo processo nela determinado.

Art. $3^{\circ}$. A posse do Governador eleito se dará perante a Assembléia Legislativa, no mesmo dia da promulgação da Constituição Estadual.

Parágrafo único. Até essa data o Acre permanecerá sob a administração do Governo Federal, através do regime atual de um delegado da União.

Art. $4^{\circ}$. O mandato dos eleitos, na forma do art. $2^{\circ}$ desta lei, findará a 31 de janeiro de 1965.

Art. $5^{\circ}$. O reajustamento constitucional do número de representantes do Acre na Câmara dos Deputados, bem como a escolha dos seus três Senadores, far-se-á quando das eleições gerais do Congresso Nacional para a próxima legislatura.

Parágrafo único. O Senador eleito com a menor votação terá apenas quatro anos de mandato.

Art. $6^{\circ}$. Para o exercício financeiro subseqüente à promulgação da Constituição Estadual, o Governo do Acre perceberá da União um auxílio correspondente ao valor global das verbas orçamentárias que hajam sido atribuídas ao então Território, no ano interior.

Art. $7^{\circ}$. O Governo da União promoverá entendimentos com o novo Estado a fim de celebrar convênio, vigorante a partir do segundo exercício financeiro após a posse do Governador eleito, estabelecendo:

a) Que a administração federal concorrerá, durante o período de dez anos, com uma dotação anual de Cr\$ 300.000.000,00 (trezentos milhões de cruzeiros).

b) Que o poder público estadual se obrigará, no mesmo prazo, a:

1 - aplicar, no mínimo, 50\% (cinqüenta por cento) dessa subvenção no fomento da riqueza regional;

2 - limitar ao máximo de 3\% (três por cento), por transação, a incidência do imposto de vendas e consignações.

Art. $8^{\circ}$. Passarão para a jurisdição do Estado os serviços e bens a cargo do Território, ou do Governo Federal, obedecendo-se o que dispõem a Constituição e as leis. 
$\S 1^{\circ}$. As autoridades judiciárias, serventuários da justiça e demais servidores territoriais continuarão em exercício por conta da União, até que sejam substituídas, mediante investidura legal, pelos órgãos próprios da organização constitucional do Estado.

$\S 2^{\circ}$. Efetivada essa substituição, os servidores públicos intitulados de estabilidade legal e os magistrados e os titulares de ofícios de justiça serão postos em disponibilidade de acordo com a legislação vigente, até serem aproveitados em outras funções equivalentes, por sua natureza e estipêndios.

Art. $9^{\circ}$. Caberá à União o pagamento da importância que for em definitivo arbitrada, como justa indenização ao Estado do Amazonas, pela perda do Acre Setentrional.

Art. 10. Até que seja instalado o Tribunal Regional Eleitoral do Acre, suas funções serão exercidas pelo Tribunal Regional Eleitoral do Distrito Federal.

Art. 11. Esta Lei entrará em vigor na data de sua publicação, revogadas as disposições em contrário.

Sala Rêgo Barros, 29 de março de 1960. - César Prieto, Presidente - Jayme Araújo, relator ${ }^{153}$.

Em 1961, dando continuidade às discussões no âmbito da Câmara Federal, o Presidente Ranieri Mazzilli, em reunião realizada em 17 de janeiro, esclarece que é necessário o quorum mínimo de 218 , na forma do disposto no parágrafo $7^{\circ}$, do artigo 182 , do Regimento da Câmara, e que "aceita a emenda pela Câmara em duas discussões com interstício de cinco dias e por maioria absoluta da totalidade dos deputados, será enviada ao Senado"154. Caso esta seja aprovada em primeira discussão, irá ser submetida a segunda discussão.

Na segunda discussão, ao Projeto foram anexadas as seguintes emendas:

$\mathrm{N}^{\mathrm{o}} 1$

Os créditos a que se refere esta Lei serão automaticamente registrados no Tribunal de Contas e distribuídos ao Tesouro Nacional em março, julho e novembro de cada ano, para imediata entrega à administração do Acre.

$\mathrm{N}^{\mathrm{O}} 2$

Substitua-se o art. $8^{\circ}$ pelo que se segue:

Art. $8^{\circ}$. A partir da data da promulgação da Constituição Estadual ficam atribuídos ao Estado do Acre e a ele incorporados:

a) todos os bens, serviços e respectivos pessoal ativo e inativo do Território do Acre;

b) todos os serviços públicos de natureza local, exercidos pela União no Território do Acre e por ela não aproveitados, inclusive a Justiça, o

${ }^{153}$ Ibid., p. 2226-227.

${ }^{154}$ Ibid., p. 373-375. 
Ministério Público, a Polícia e a Guarda Territorial, com todos os respectivos bens e pessoal ativo.

$\S 1^{\circ}$. O pessoal dos serviços mantidos pela União e transferidos ao Estado na forma deste artigo, continuará a ser remunerado pela União, inclusive o que passar à inatividade; mas passarão a ser remunerados pelo novo Estado, que os proverá na forma da Lei, os novos servidores nomeados para cargos iniciais de carreira ou cargos isolados que se vagarem e para cargos que vierem a ser criados, bem como os acréscimos de vencimentos, proventos e vantagens estabelecidos pelo novo Estado.

$\S 2^{\circ}$. A aposentadoria dos servidores remunerados pela União será por esta decretada ficando a seu cargo o pagamento do respectivo proventos, e também assegurado, sem restrições o direito dos atuais contribuintes de entidades federais de previdência.

$\S 3^{\circ}$. Todos os bens móveis e imóveis, encargos e rendimentos, inclusive os de natureza fiscal, direitos e obrigações relativos aos servidores mantidos pela União no Território, passarão ao patrimônio do novo Estado, sem indenização na data da promulgação de sua Constituição.

$\S 4^{\circ}$. Os serviços transferidos na forma do artigo continuarão regidos pela legislação vigente, enquanto não modificada pelos Poderes competentes do novo Estado, ao qual incumbe sobre eles legislar inclusive sobre o pessoal transferido, bem como administrá-los, provendo-lhes e movimentando-lhes os quadros.

$\S 5^{\circ}$. Os servidores federais transferidos ao novo Estado serão remunerados pela União de maneira nunca inferior aos do mesmo cargo ou de correspondente categoria nos demais Territórios Federais.

$\mathrm{N}^{\circ} 3$

Acrescente-se onde couber:

Art. Ficam revogadas todas as leis que estabeleceram isenção de impostos no Território do Acre e autorizado o governo local a organizar e promover a arrecadação deles a partir do ano seguinte ao da vigência desta Lei, dentro das condições estabelecidas em regulamento a ser expedido pelo poder executivo.

Art. Caso no segundo exercício de arrecadação dos impostos da natureza daqueles que competem aos Estados não tenha atingido a receita cifra superior a despesa no mesmo período, ficará suspensa a execução desta lei até que ocorra o equilíbrio orçamentário aqui mencionado ${ }^{155}$

A Comissão de Constituição e Justiça, avaliando a matéria, posicionou-se a respeito

através do seguinte substitutivo:

O Congresso Nacional decreta:

Art. $1^{\circ}$. O Território do Acre, com seus atuais limites, é erigido em Estado do Acre.

Art. $2^{\circ}$. A Justiça Eleitoral fixará, dentro de três meses, após a promulgação da presente Lei, a data das eleições de Governador e de Deputados à Assembléia Legislativa, os quais serão em número de quinze e terão, inicialmente, funções constituintes.

Art. $3^{\circ}$. A Assembléia Legislativa reunir-se-á dentro de dez dias da diplomação, sob a direção do Presidente do Tribunal Regional Eleitoral por convocação deste, e elegerá a sua Mesa.

${ }^{155}$ Ibid., p. 373-375. 
Parágrafo único. Se dentro de quatro meses, após a instalação da Assembléia não for promulgada a Constituição Estadual, o Estado do Acre ficará submetido automaticamente à do Estado do Amazonas, até que a reforme pelo processo nela determinado.

Art. $4^{\circ}$. A posse do primeiro governador se fará perante a Assembléia Legislativa no dia da promulgação da Constituição Estadual.

Parágrafo único. Até essa data, o Estado do Acre ficará sob a administração do Governo Federal através de um Governador provisório.

Art. $5^{\circ}$. O mandato dos Deputados eleitos, na forma do art. $2^{\circ}$, findará a 31 de janeiro de 1962.

Art. $6^{\circ}$. O número de representantes do Estado do Acre na Câmara dos Deputados será fixado em Lei Especial e a sua eleição, juntamente com a dos Senadores, verificar-se-á na data das eleições gerais do Congresso Nacional para a próxima Legislatura.

Parágrafo único. O Senador eleito, com menor votação, terá o mandato de quatro anos.

Art. 7Å. As dotações consignadas no atual Orçamento Geral da União para o Território do Acre serão transferidas à aplicação do Governo do Estado, mediante convênio.

Parágrafo único. No exercício financeiro subseqüente ao da promulgação da Constituição Estadual, o Governo do Acre perceberá da União um auxílio correspondente ao valor global das verbas orçamentárias que hajam sido atribuídas ao Território, no exercício anterior.

Art. $8^{\circ}$. A União celebrará convênio com o Estado do Acre, a vigorar do exercício financeiro seguinte, ao da promulgação da Constituição do Estado, para que:

a) A União concorra, durante o período de dez anos contínuos, com um auxílio anual não inferior a Cr\$ 300.000.000,00 (trezentos milhões de cruzeiros) e mais, por tempo indeterminado, com a contribuição de que trata o art. $9^{\circ}, \S 6^{\circ}$

b) o Estado se obrigue, no mesmo prazo, a:

1 - aplicar, no mínimo, 50\% (cinqüenta por cento) desse auxílio no fomento da riqueza regional;

2 - limitar, ao máximo de 3\% (três por cento), por transação, a incidência do imposto de vendas e consignações.

Art. $9^{\circ}$. A partir da data da promulgação da Constituição Estadual ficam atribuídos ao Estado do Acre e a ele incorporados:

a) todos os bens, serviços e respectivo pessoal ativo e inativo do Território do Acre;

b) todos os serviços públicos de natureza local, exercidos pela União no Território do Acre e por ela não aproveitados, inclusive a Justiça, o Ministério Público, a Polícia e a Guarda Territorial, com todos os respectivos bens e pessoal ativo.

$\S 1^{\circ}$. O pessoal nos serviços mantidos pela União e transferidos ao Estado na forma deste artigo, continuará a ser remunerado pela União inclusive o que passar à inatividade; mas passarão a ser remunerados pelo novo Estado, que os proverá na forma da lei, os novos servidores nomeados para cargos iniciais de carreira ou cargos isolados que se vagarem e para cargos que vierem a ser criados, bem como os acréscimos de vencimentos, proventos e vantagens estabelecidos pelo novo Estado.

$\S 2^{\circ}$. A aposentadoria dos servidores remunerados pela União será por essa decretada, ficando a seu cargo o pagamento dos respectivos proventos e também assegurado, sem restrições, o direito dos atuais contribuintes de entidades federais de previdência. 
$\S 3^{\circ}$. Todos os bens móveis e imóveis, encargos e rendimentos, inclusive os de natureza fiscal, direitos e obrigações relativos aos serviços mantidos pela União no Território passarão ao patrimônio do novo Estado, sem indenização, na data da promulgação de sua Constituição.

$\S 4^{\circ}$. Os serviços transferidos na forma deste artigo continuarão regidos pela legislação vigente, enquanto não modificada pelos Poderes competentes do novo Estado, ao qual incumbe sobre eles legislar inclusive sobre o pessoal transferido, bem como administrá-los, provendo-lhes e movimentando-lhes os quadros.

$\S 5^{\circ}$. Os servidores federais transferidos ao novo Estado serão remunerados pela União de maneira nunca inferior aos de mesmo cargo ou de correspondente categoria nos demais Territórios Federais.

$\S 6^{\circ}$. Caberá à União auxiliar o Estado a pagar aos desembargadores de Tribunal de Justiça a diferença entre os seus vencimentos e os dos juízes de entrância mais elevada ou única, até ser a mesma absorvida por majorações outorgadas pelos poderes constitucionais do Estado.

Art. 10. Caberá à União o pagamento da importância que for em definitivo arbitrada como justa indenização ao Estado do Amazonas, pela perda do Acre Setentrional.

Art. 11. Até que seja instalado o Tribunal Regional Eleitoral do Acre, suas funções serão exercidas pelo Tribunal Regional Eleitoral do Distrito Federal.

Art. 12. As verbas e créditos orçamentários ou especiais destinadas ao Estado do Acre, em virtude da presente lei independem de registro prévio no Tribunal de Contas e serão depositados com caráter prioritário, em conta especial do Banco do Brasil S. A, à disposição do Governo estadual em três parcelas iguais durante os meses de março, julho e novembro de cada ano.

Art. 13. Esta lei entrará na data de sua publicação, revogadas as disposições em contrário ${ }^{156}$.

O substitutivo da Comissão de Constituição e Justiça foi aprovado integralmente pela Comissão de Finança, sendo o texto final redigido pela Comissão de Redação, em 7 de abril de 1961, e assinado por Medeiros Neto, Salvador Losacco e Paulo Lauro (KALUME, 1985, p. $383)$.

E, após a sua leitura e aprovação na seção da Câmara Federal, em 12 de abril de 1961,

Guiomard Santos, fazendo uso da palavra, agradece aos seus pares dizendo:

O projeto de autonomia do Acre sai desta Casa meticulosamente estudado durante quatro anos e cria com prudência, zelo e dignidade o caçula dos Estados brasileiros, lanço o meu apelo ao Senado, onde não temos nenhuma voz, para que naquela restrita assembléia se tenha em conta que o Acre já foi uma república independente; que os Partidos, as pessoas e quizílias de hoje pouco valem diante da perenidade das grandes causas; que o regime de

${ }^{156}$ Ibid., p. $375-377$. 
Território, com poder executivo nomeado, é um pró-consulado que abastarda e deseduca os cidadãos para a democracia; que junto com a autonomia política o projeto contém implícito um plano de investimentos reprodutivos; e sobretudo a votação unânime com que a Câmara dos Deputados acolheu este projeto[... $]^{157}$.

Vencida esta etapa, o projeto aprovado na Câmara foi encaminhado ao Senado, através do Senador Cunha Mello, Primeiro-Secretário do Senado Federal, sendo protocolado nas suas instâncias em 25 de abril de 1961.

Seguindo o ritual burocrático, foram distribuídas cópias as Comissões de Justiça (relator Silvestre Péricles) de Economia (relator Del Caro), de Finanças (relator Barros Carvalho) e do Serviço Público (relator Fausto Cabral), os quais emitiram pareceres favoráveis.

No entanto, frente às observações feitas quando das primeiras discussões, o Senador Cunha Mello encaminhou expediente ao Ministério da Justiça e dos Negócios Interiores solicitando informações para melhor instruir o processo, referentes as seguintes indagações.

I - Qual a renda nesses últimos cinco anos de 1956, 1957, 1958, 1959 e 1966, ano a ano do Território Federal do Acre?

II - Qual o montante das despesas da União no mesmo período, ano por ano, feitas com o referido Território, incluídas as verbas nele empregadas e nos seus Municípios?

III - Qual a despesa anualmente orçada e realmente realizada para os seus diversos serviços?

O Ministro elaborou extenso e detalhado quadro da situação financeira do Território do Acre, destacando entre as despesas da União, a despesa orçada e a despesa efetivamente

${ }^{157}$ SANTOS, José Guiomard dos. Diário do Congresso Nacional - seção I, 14 de abril de 1961. 
realizada, respectivamente em 95.821.739.95, 1.837 .353 269,85 e 1.294. 126, 401,05 evidenciando que vários itens não foram computados em cada um dos valores acima expressos.

Em 1962, através dos pareceres de números 140, 141 e 142, cada relator apresentou as suas observações, porém todos defenderam a constitucionalidade e pertinência do projeto, aprovando-o, sendo o mesmo colocado em discussão, incluindo em ordem do dia, pois houve a dispensa do tempo de interstício, conseguido através de requerimento encaminhado pelo senador Lima Teixeira, sendo este unanimemente aprovado, sem discussão, em 2 de junho de 1962.

Em 5 de junho do mesmo ano, foi encaminhado ao Presidente João Belchior Marques Goulart, pelo presidente do Senado Federal, Senador Auro Moura Andrade, que através da mensagem de $n^{\circ} 123$, datada de 15 de junho de 1962, embora reconhecendo o mérito do projeto e sua importância para o desenvolvimento do Acre, apresentou veto parcial acerca das seguintes questões:

[...] incide veto sobre os artigos $5^{\circ}$ e $6^{\circ}$, e respectivo parágrafo único, do projeto, pelas razões a seguir expostas:

Quanto ao artigo $5^{\circ}[\ldots]$ dado o tempo decorrido da data nele fixada para o término do mandato dos deputados à Assembléia Legislativa, tornou-se desatualizados. . .

Impõe-se o veto; também ao artigo $6^{\circ}$ e respectivo parágrafo único, porque a sua manutenção poderia ensejar interpretações inteiramente contrárias aos interesses nacionais [...]

Vetados os dispositivos, porém, tal hipótese não ocorrerá, porque a matéria já está adequadamente tratada pela Constituição Federal. [. . .] submeto à elevada apreciação dos Senhores Membros do Congresso Nacional ${ }^{158}$

${ }^{158}$ Ibid., p. $489-490$. 
Nesse mesmo dia, em solenidade no Palácio do Planalto, na tarde de 15 de junho de 1962, o presidente João Goulart sancionou a lei 4.070, que elevou o Território do Acre a Estado.

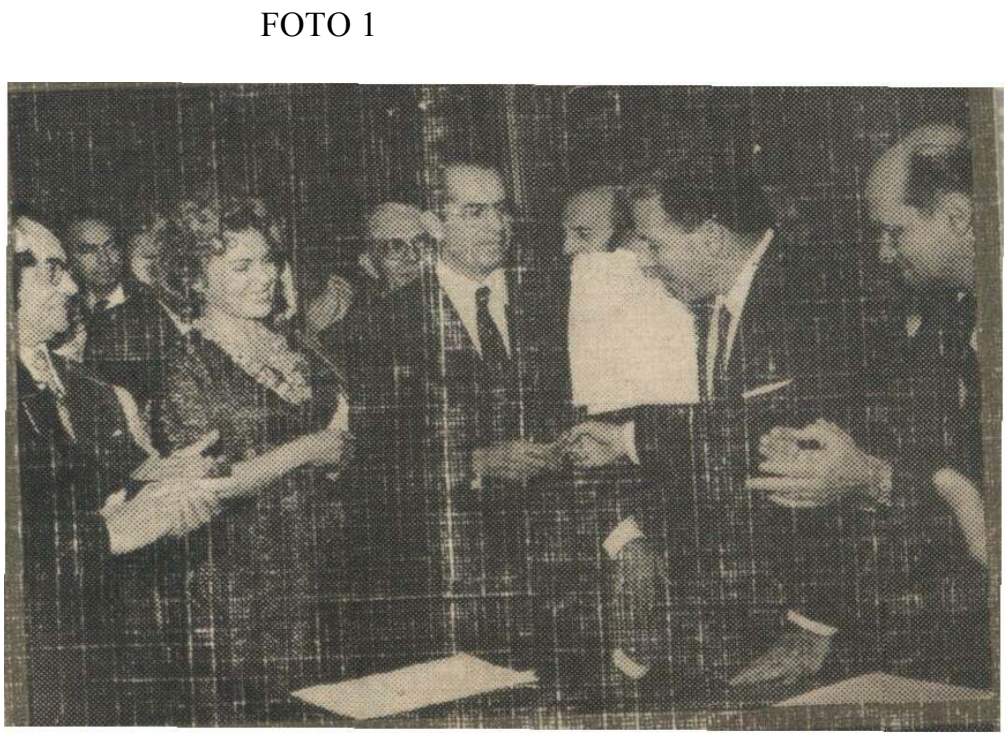

Da esquerda para a direita, Lydia Santos, Guiomard Santos, Presidente João Goulart, Primeiro Ministro Tancredo Neves. 1962. Acervo: C.D.I.H.

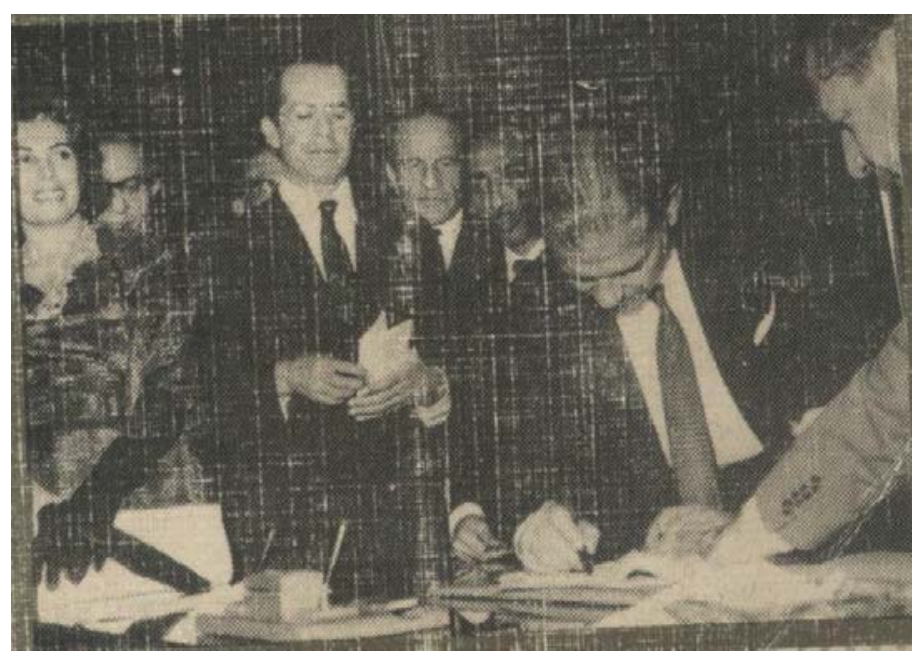

Presidente João Goulart assinando a Lei 4.070, que elevou o Acre a Estado. 1962. Acervo: C. D. I. H 
Inserindo o processo de elevação do Acre no contexto político-partidário nacional de 1954 a 1962, pode-se inferir que a capacidade de articulação política de Guiomard Santos junto aos parlamentares tanto da Câmara quanto do Senado Federal só foi possível devido à aliança PSD-PTB iniciada em 1954 com a eleição de Juscelino Kubitschek para a Presidência da República.

O jogo das forças políticas que caracterizam o período em tela é nitidamente marcado pelo suicídio do Presidente Vargas e pela prática política dos herdeiros do Varguismo em confronto com a União Democrática Nacional (UDN) e a materialização do projeto de modernização econômica do Brasil que passava, necessariamente, pela industrialização brasileira.

Outro fato que merece destaque é que o consórcio PSD-PTB possibilitou que a ordem social e a ordem pública fossem mantidas frente a conjuntura de ebulição social gerada pela pressão das "massas" quanto as reformas de base e o temor que estas apresentavam para as elites nacionais, sobretudo as ligadas ao capital internacional, as preocupações e tentativas dos militares de quebra da normalidade institucional do país diante do que conceituavam de “comunização" do Brasil e a ação das novas camadas urbanas mobilizadas pela redistribuição das vantagens advindas com o desenvolvimento econômico.

Portanto, a aliança PSD-PTB permitiu, de um lado, que os interesses da elite rural brasileira fossem preservados, uma vez que o sistema de poder e propriedade no campo permaneciam intocáveis na sua essência e também preservou os do empresariado (não apenas dos vinculados ao capital estrangeiro, como os dos que dependiam de créditos) pois a política financeira permaneceu controlada pelo PSD e, ainda manteve sob controle as reivindicações dos setores urbanos.

Essa aliança exercia influência direta no legislativo e no plano das instituições, o Legislativo tinha um peso considerável, apesar de estar perdendo continuamente sua 
capacidade decisória, o que não implicava no seu poder de obstrução do Congresso, se necessário.

Essa margem de autonomia decisória do Congresso se revelava, principalmente, na possibilidade de controlar o orçamento (quebrada pós-64), inclusive parte das verbas especiais da Presidência, e instituir Comissões Parlamentares de Inquérito de razoável "poder de fogo".

A força da aludida aliança no Congresso Nacional garantia a continuidade do mundo político, além de assegurar a legitimidade no jogo parlamentar, fornecendo munição ideológica para o governo e a imprensa.

Ao mesmo tempo, possibilitava que o Congresso se tornasse o canal de circulação de demandas setoriais dos grupos sociais de apoio ao governo: os deputados da aliança dominante tinham tanto a possibilidade de fazer passar projetos de lei favoráveis as suas bases regionais, quanto a possibilidade de freqüentar gabinetes ministeriais para assegurar obras, empregos e mais votos nas eleições futuras.

Esse tipo de ação política era o forte do PSD, sobretudo por ter uma tradição de mando mais arraigada e ter reunido desde o Estado Novo Varguista as oligarquias agrárias com os altos burocratas, os "tenentes", os homens das altas finanças e os antigos interventores nos Estados.

Mas o PTB também exercitava o jogo de reprodução do mando no âmbito do Ministério do Trabalho e na máquina da Previdência Social. E, nesse sentido, é importante ter em mente a relevância do Ministério do Trabalho como fonte de empregos públicos, além do fato de o clientelismo e o empreguismo serem usados pelos petebistas não apenas como "moedas" de troca, de favores políticos, mas, também, como elementos de cooptação de lideranças sindicais.

Essa participação do PTB na estrutura do Estado não só garantia sua permanência no núcleo de poder ao nível do Executivo como facilitava sua continuidade eleitoral no 
Legislativo, e no nível partidário possibilitava seu crescimento e legitimação como "portavoz" das classes trabalhadoras, o que era uma necessidade para a manutenção do jogo populista da época.

Importante ainda levarmos em conta que os anos 50 e 60 do século $\mathrm{XX}$ foram fortemente marcados pela Guerra Fria e no caso específico da América Latina, a Revolução Cubana, em 1959, fez com que os E. U. A fortalecessem e diversificassem as suas estratégias de dominação no continente americano ameaçado pelo "perigo vermelho" ou o "olho de Moscou".

Portanto, como desdobramento da aliança nacional PSD-PTB em nível local, foi possível aos defensores do projeto de elevação do Acre a Estado, de autoria de Guiomard Santos (PSD), construírem politicamente uma base de apoio político ao mesmo, sobretudo considerando-se que os governadores do Território do Acre, José Lino da Silveira Araújo e depois Aníbal Miranda, pertenciam às fileiras do PTB-AC.

Tornando-se o Acre Estado, as "baterias foram esquentadas" para a mobilização das eleições de governo, apresentando-se como candidatos, pelo PSD, José Guiomard dos Santos e pelo PTB, José Augusto de Araújo. Vencendo o pleito eleitoral este último, Guiomard Santos foi eleito Senador.

A partir de então, os esforços foram concentrados no sentido da instalação da Assembléia Constituinte, sendo esta composta pelos deputados estaduais diplomados, no último pleito, a saber: Francisco Thaumaturgo, Nabor Teles da Rocha Júnior, José Fonseca de Araújo, Guilherme Zaire, Joaquim Macedo, Augusto Hidalgo de Lima, Adonay Barbosa dos Santos, Eloy Abud, Francisco Aluizo de Queiroz, Omar Sabino de Paula, Joaquim Lopes da Cruz, José Chaar, Carlos Afonso, Benjamin de Jesus Ruela e Geraldo Reis Fleming, sendo em 1 de março de 1963 promulgada a primeira Constituição do Estado do Acre.

O Acre era Estado... 
$2.2-\mathrm{E}$ as mulheres foram à luta - as legionárias do Acre

“A mulher não ficou passiva nessa luta. Na verdade, as mulheres tiveram um engajamento significativo[.. .]"

Iriscélia Cabanella

Nesta parte do capítulo, a nossa perspectiva é trazer as falas das mulheres legionárias buscando apreender seus discursos e suas práticas.

$\mathrm{E}$, nesse sentido registramos que a produção do presente texto não estava prevista ao iniciarmos as cem entrevistas com os moradores mais antigos da cidade de Rio Branco, acerca da elevação do Acre a Estado, nos idos de 1996, quando resolvemos que o objeto de investigação de nossa tese de doutoramento seria a emancipação política do Acre, embora posteriormente este tenha sido ampliado.

Até aquela oportunidade, as pesquisas que tínhamos desenvolvido não nos chamavam à atenção para o significativo papel que as mulheres do Acre tiveram no que se refere a emancipação política do Acre.

Iniciando as entrevistas, os relatos dos nossos entrevistados nos revelaram as legionárias e, então, resolvemos aprofundar os nossos estudos acerca desta temática, inclusive, na perspectiva de dedicarmos uma parte do trabalho à abordagem desta questão.

A partir de então resolvemos ouvir as histórias das legionárias do Acre, na medida que suas histórias as preservariam do esquecimento, além de contribuir para a construção de suas identidades e do legado que estas deixam para o futuro.

Com base no exposto passamos a observar a relação entre suas histórias e um outro tempo, o tempo do Guiomard.

Ao iniciarmos a execução dos relatos orais, foi possível percebermos que 
Uma história de vida é algo vivo. Sempre é um trabalho de evolução, no qual os narradores examinam a imagem do seu próprio passado enquanto caminham. A dificuldade que entrevistadores (e narradores) muitas vezes encontram em finalizar uma entrevista mostra sua compreensão de que a estória que estão contando é aberta, provisória e parcial.

[. . .] Assim, as estórias mudam tanto com a quantidade de tempo (os aspectos que ele quer enfatizar durante a narrativa). Nenhuma estória será contada duas vezes de forma idêntica $[\ldots]^{159}$

E, no decorrer da seqüência de entrevistas fomos observando que relações as legionárias estabeleciam entre suas memórias e o tempo, o que lembravam, como cada narradora cruzava seu relato com os de suas companheiras de militância, que imagem tinham construído do vivido, que práticas nortearam o fazer político destas mulheres da "selva", que profissões tinham e como atualmente avaliam o engajamento na luta pró-Estado do Acre.

Numa época em que a imagem dominante da mulher era de "rainha do lar", como as legionárias se posicionavam? Que leituras faziam do mundo da política onde adentraram "guiadas" pelos homens, os chefes políticos locais, Guiomard Santos e Oscar Passos? Que imaginário tinham da política da época?

Vale destacarmos que a presença da mulher como sujeito histórico ainda é um tema pouco estudado pela literatura e história acreanas, especialmente no que se refere a períodos anteriores a 1970, quando em decorrência da resistência à expulsão de suas posses, os seringueiros se organizaram dando surgimento ao movimento sindical rural. Foi nesse processo que a participação política da mulher acreana ganhou maior visibilidade pública, embora esta estivesse presente, de forma significativa, no processo de extração do látex desde o $2^{\circ}$ surto da goma elástica, quando ocorreu a batalha da borracha.

\footnotetext{
${ }^{159}$ PORTELLI, Alessandro. O momento da minha vida: funções do tempo na história oral. In: FENELON, Déa Ribeiro et al (Org.) Muitas memórias, outras histórias. São Paulo: olho d'água, 2004, p. 298.
} 
E, muito embora, o número de homens no seringal tenha sido sempre bem maior que o das mulheres, mormente no primeiro surto da borracha $(1870$ - 1912), a presença feminina não pode ser ignorada.

Nesse universo, as relações de gênero foram além dos modelos estabelecidos pela cultura ocidental, pois essas mulheres no cotidiano que viviam no seio da "selva" tiveram que improvisar novos papéis e estratégias de vida que expressavam suas resistências e lutas.

Isoladas no seio da floresta, defrontando-se com parcos recursos materiais, marcadas por relações sociais em que a violência estava presente, sendo obrigadas a uma dupla ou tripla jornada de trabalho frente aos seus múltiplos afazeres foram partícipes de uma sociedade diferenciada porém interligada ao contexto mundial.

As trajetórias dessas mulheres índias ou nordestinas, principalmente ou descendentes destes foram silenciadas por uma produção historiográfica tradicional que ou as julgava insensíveis ou de pouca importância.

Em 1904, quando o Aquiri foi incorporado ao território nacional como Território do Acre, o prefeito do Departamento do Alto Acre, Cunha Matos, embora ressalte a dificuldade de se obter um recenseamento da população frente a carência de pessoal qualificado para esta tarefa, por um lado, e as dificuldades de comunicação e a dispersão da população nos seringais, por outro, impedissem estatísticas perfeitas, obtendo apenas dados acerca da $4^{\mathrm{a}}$ circunscrição do Departamento, a qual se estendia de Boca do Riosinho até o seringal Apiluy, assinala que nesta área "até 20 de dezembro havia 2.376 habitantes: 1.682 homens e 694 mulheres. .."160.

A superioridade considerável da população de homens era preocupação constante dos administradores durante os primeiros anos do sistema Departamental, na medida que para

\footnotetext{
${ }^{160}$ MATTOS, Rapahel Augusto da Cunha. Relatório apresentado ao Exmo. Sr. Dr. José Joaquim Seabra, Digno Ministro da Justiça e Negócios Interiores, pelo coronel de Arma da Infantaria Raphael Augusto da Cunha Mattos, Prefeito do Departamento do Alto Acre, 1904. p. 11.
} 
fixar o homem a terra, fazer com que o migrante nordestino criasse raízes no Acre era fundamental que este formasse uma família.

Alguns nordestinos que vieram no primeiro surto da borracha (1870-1912) casaram, informalmente, com mulheres índias, porém isto não era tão comum diante do fato de que para o índio, o nordestino-seringueiro foi o colonizador, acrescido do preconceito que este nutria dos povos indígenas.

Nessa época, as mulheres eram vistas como "bem de luxo" de seringalistas abastados e/ou de seringueiros com saldo - estes últimos mandavam buscar mulheres nos bordéis das praças de Belém e Manaus, mas nem sempre estas se adaptavam, muitas vezes retornando aos seus locais de origem. Nesse contexto, a mulher se constituía "mercadoria" listada e comprada.

Os seringueiros, no seu infortúnio, encomendavam aos "patrões" e estes às "Casas Aviadoras", mulheres, como encomendavam gêneros alimentícios, utensílios, roupas, etc. Verdadeiras mercadorias, entravam nas contas, escrituradas pelos guarda-livros como quaisquer outros objetos de uso diário ${ }^{161}$.

O depoimento de um ex seringueiro do Alto Juruá denota como ocorria a compra e venda de mulheres no Alto Juruá.

ter uma mulher em um seringal daquele tempo era como ter objeto de luxo, que se podia comprar por quinhentos quilos de borracha, segundo o sr. João Cunha, de 81 anos, e que era necessário manter com trabalho redobrado, pois senão o patrão tirava e dava para outro[. . . $]^{162}$

Em 1909, o prefeito do Alto Acre, Gabino Besouro assinala:

[. . . contrariamente ao que sucede em todos os demais países [. . .] podese neste Departamento calcular com segurança que o número de homens

${ }^{161}$ REIS, Arthur Cezar Ferreira. O seringal e o seringueiro. Rio de Janeiro: Serviço de Informação Agrícola, 1953, p. 123.

${ }^{162}$ CUNHA, João. In: Mulheres da floresta, uma história. Alto Juruá, Acre (1890 - 1945), São Paulo: Hucitec, 2003. p. 71-72. 
supera em dois terços ao de mulheres. [. . .] Sem família o homem não se vincula ao solo. . . [. . .] Sem população de vida sedentária, fixa que tome amor ao solo de onde tira os meios de subsistência e que se torne o berço dos seus filhos, fazendo o homem retirar da mente o pensamento de voltar a terra natal. ${ }^{163}$

Portanto, foi só a partir da década de 1940 que o número de mulheres no Acre passou a ser mais proporcional ao dos homens.

Em Rio Branco, sede do Departamento do Alto Acre, depois capital do Território do Acre, a partir de 1920, e do Estado do Acre desde 1962, o número de mulheres nas primeiras décadas do século XX também era reduzido, embora bem maior que nos seringais, e estas limitavam-se na quase totalidade as tarefas domésticas, sendo a mulher pública vista com desconfiança.

\begin{abstract}
No capitalismo, seja como proprietário dos meios de produção ou como operador dos mesmos, por meio da venda da sua força de trabalho, o homem definiu-se essencialmente como produtos de mercadorias.

[. . .] A mulher, expulsa do universo econômico criador do sobreproduto, cumpriu, apesar disso, uma função econômica fundamental. A divisão do trabalho designou-lhe a tarefa de repor a maior parte da força de trabalho que move a economia, transformando matérias-primas em valores de uso para seu consumo direto, ocorrendo, deste modo, à alimentação, ao vestuário, à manutenção da casa, assim como a educação dos filhos [. . . $]^{164}$
\end{abstract}

As que trabalhavam para ampliar a renda familiar o faziam no âmbito da casa como doceiras, bordadeiras, costureiras e outros serviços assemelhados, enquanto outras dedicavam-se ao magistério, algumas na própria residência, ou à administração pública, sobretudo após 1920, e muito embora o trabalho doméstico fosse visto como uma característica sexual secundária, em vez de categoria econômica, a contribuição destas mulheres para o sustento de suas famílias era considerável.

\footnotetext{
${ }^{163}$ BESOURO, Gabino. Relatório apresentado ao Exmo. Sr. Ministro do Interior e Justiça, Dr. Augusto Tavares de Lyra, Villa Rio Branco. Departamento do Alto Acre, 1909, p. 17-18.

${ }^{164}$ LARGUIA, Isabel. DUMOULIN, John. Trabalho visível e trabalho invisível. In: Para uma ciência da libertação da mulher. São Paulo: Global, 1990. p. 14-15.
} 
[.. . ] o trabalhador e a sua família não se sustentam só com o que compram com o seu salário, mas também com o que resulta de a dona de casa e os seus familiares transformarem muitas horas em trabalho doméstico e outras tarefas de subsistência. Para se ter uma idéia do contributo das donas de casa, suponhamos que se dedicam só uma hora diária à manutenção de cada um dos seres humanos que existem na terra (cifra absolutamente conservadora): chegaríamos a um número muito superior a três bilhões de horas de trabalho invisível realizadas diariamente[. . . ]. ${ }^{165}$

Vale acrescentar que, foi a partir do governo de Guiomard Santos que quantitativo e qualitativamente a mulher exerceu de forma mais efetiva a sua condição de sujeito político, através do engajamento nas lutas partidárias do PSD e do PTB, tanto e principalmente em Rio Branco, quanto nos municípios do interior. Acrescido do fato de que tanto o PSD quanto o PTB foram partidos criados por Getúlio Vargas em 1945.

Por outro lado, embora a causa da autonomia acreana, se constituísse um projeto das forças políticas locais, estas buscaram referendar o seu propósito popularmente através de várias agremiações que tinham como prosélitos homens e mulheres, considerando que desde 1934 o voto feminino foi institucionalizado.

Por que "legionárias"?

O termo "legião" está vinculado ao corpo do antigo exército romano constituído de cavalaria e infantaria. No entanto, no imaginário político dos autonomistas, o léxico "legião" adquiriu a acepção de "exército" combatente, coerente com o discurso patriótico que o Estado brasileiro assumiu após a proclamação da República.

A legionária era aquela que incansavelmente trabalhava em prol de uma causa nobre, da pátria, do Estado.

Portanto, cabia às legionárias combaterem pelo Acre, pela emancipação política do Acre. E em nome de um Acre independente, as mulheres, especialmente em Rio Branco, embora existissem legionárias em todo o território do Acre, passaram a atuar de forma “aguerrida" nos embates políticos locais.

${ }^{165}$ Ibidem. p. 16. 
As mulheres tiveram um engajamento significativo nesta luta. Primeiro porque as jovens daquela época eram quase todas normalistas, tinham nível cultural, eram professoras normalistas. Queriam um Acre poderoso, tinham ideais político-partidiários. E em torno do General Guiomard Santos, que tinha sido governador, criou-se para dar apoio ao partido político dele, as legionárias, para que ele pudesse conduzir o projeto de autonomia que ele prometia, se fosse para a Câmara Federal. ${ }^{166}$

Importante considerarmos que a visão ideológica de Guiomard Santos era marcadamente patriótica. Nesse caso, os ideais do Estado, da pátria, estão acima dos interesses individuais - aliás, ele se autodenominava "soldado-cidadão".

Essa idéia veio dele, depois a gente estudando, todo mundo sabe que isso vem da Europa. Muito ligada a movimento políticos da Europa, mas nós não tínhamos esse conhecimento. As legionárias seriam equipes de força, de mobilização da sociedade em prol desse projeto - criar um Acre forte para os filhos, que eles seriam mais felizes que naquela sociedade prematura. ${ }^{167}$

Às legionárias cabia a execução de várias atividades políticas, culturais e sociais no âmbito do partido e fora deste, como preparar as atividades culturais que seriam realizadas nos comícios, como cantos, palavras de ordem, poesias, jograis, peças teatrais. No entanto, o teor dessas atividades estava voltado para o engrandecimento da pátria. $\mathrm{O}$ uso da educação como controle ideológico, como forma do Estado guiar e conduzir o povo, era uma prática que não só dava organicidade à luta pró-autonomia como a legitimava frente aos opositores.

Eram poesias, canções, até as roupas. Nós vestíamos branco e tínhamos uma faixa amarela. A gente dizia até que era roupa do Papa porque tinha as cores do Papa. E as nossas canções se sobrepunham as canções do grupo do General Oscar Passos, que também tinha as suas legionárias. Não era tônica de agressividade, mas tinha um esclarecimento para o povo. ${ }^{168}$

A instrumentalização da mulher como "tropa de choque" passa a ser a tônica do PSD e do PTB.

${ }^{166}$ CABANELLA, Iriscélia: depoimento [10 de julho de 2004]. Entrevistadora. Maria José Bezerra. Rio Branco. ${ }^{167}$ Ibid., ${ }^{168}$ Ibid., 
A construção da mulher legionária como sujeito-político ocorreu a partir da cadeia de significados socialmente construídos - esposa, mãe, educadora e patriota, ela buscara identificar-se com sua condição de mãe que não apenas gera os filhos, mas é responsável pelo destino que este terá. E, na perspectiva de construir um futuro promissor para os filhos, com o Estado, ela foi à luta, passando de indivíduo para sujeito.

Embora instrumentalizadas diretamente pelo próprio Guiomard e/ou esposa, Lydia Santos, ou ainda por algum integrante do Comitê Pró-Autonomia, as legionárias não foram apenas expectadoras do seu tempo, pois fizeram deste uma vivência concreta e dinâmica.

A gente tinha que falar as realizações dele: 54 escolas, a maternidade Bárbara Heliodora, a construção do Palácio Rio Branco, os postos de saúde, o pessoal da Polícia... Tudo isso a gente tinha na ponta da língua, que era para ter matéria de revide. E a outra função era no diretório do Partido, não apenas para fazer o registro dos militantes. Nós também tínhamos que identificar os problemas, fazer uma espécie de diagnóstico da vida do povo, das necessidades do Acre e fazer encaminhamentos das pessoas que necessitavam de alimento, trabalho, escola, todos esses encaminhamentos eram feitos por nós, as legionárias ${ }^{169}$.

Mapeando a área de atuação, as legionárias evidenciam nas narrativas que construíram suas visões e representações, a partir de acontecimentos da sua própria história e/ou dos que com elas compartilharam o sonho de um Acre independente. No calor dos embates políticos, o senso comunitário, a percepção do coletivo como o locus da história se faziam presentes.

Nós tínhamos que conhecer todos os problemas da sociedade por isto a gente atuava por bairro. Cada bairro tinha as suas legionárias, inclusive nos municípios do interior do Território do Acre, as quais se comunicavam entre si. Fazíamos trabalho comunitário também. Nós íamos as colônias, saber o que estava faltando e como colaborar. Houve uma colaboração muito grande destas legionárias para o ensino na zona rural. Onde era possível chegar a gente ia. Atuávamos também nas áreas da saúde, agricultura. ${ }^{170}$

${ }^{169}$ Ibid.,

${ }^{170}$ Ibid., 
A ação política exigia ter acesso e/ou ampliar o conhecimento acerca da realidade acreana, brasileira e mundial. Mais do que fazer proselitismo político, entendiam que sua missão era melhorar o nível cultural das camadas populares.

Nós tínhamos também os momentos de encontro na sede do partido, onde nós estudávamos alguma teoria sobre socialismo, história, o que tinha acontecido em outros países, lugares. Isso era o pano de fundo de nossas conversas com as pessoas. Nós precisamos ter um Estado forte, livre do jugo, da peia usávamos aquelas palavras veementes que a sociedade acreditava muito. A gente falava o que significava os poderes constituídos, poder eleger o governador, ter uma assembléia. ${ }^{171}$

Em sua narrativa, Iriscélia entrecruza temporalidades e vivências diferentes, valores e ações de um outro tempo ligados às suas construções coletivas como mulheres e agentes políticos.

Nós tínhamos a capacidade de compreender o papel que a mulher tenha na sociedade. Tanto é que de Sena Madureira veio a grande luta pelo $1^{\circ}$ voto da mulher. Elas faziam questão de votar. Muitas mulheres votavam ${ }^{172}$.

É a construção da identidade, como sujeito político, que descobre a força do fazer histórico e se encanta com a possibilidade de construir o seu próprio caminho.

Ela acreditava que tinha que tomar a frente. Se ela não fosse a luta não seria ganha. Ela tinha mais condições. Naquele tempo a gente tinha dados extraordinários, mais mulheres na educação. A gente dizia as mulheres estão tomando conta. Elas estão conquistando o seu espaço. Há 50 anos atrás. Elas estão dando sua demonstração. Era interessante de vê. ${ }^{173}$

Lembrar é recontar, é refazer o vivido, dando às lembranças o tom, as cores, a musicalidade e a crítica política em tom de brincadeira, de deboche. Os embates entre as legionais do PSD e do PTB tinha também o seu lado irreverente, como na "música" abaixo,

\footnotetext{
${ }^{171}$ Ibid.,

${ }^{172}$ SANTOS, Lydia Guiomard dos: depoimento: [10 de maio de 1996]. Entrevistadora: Maria José Bezerra. Rio Branco.

${ }^{173}$ Ibid.,
} 
quando as partidárias de Oscar Passos (PTB) criticavam as Birico, partidárias ferrenhas do Guiomard Santos (PSD).

A biricada já está ficando louca

Tá cantando pela rua

Levantando a roupa

Levanta roupa

Prá todo mundo vê

A bandeirola do tal PSD $^{174}$.

Revisitar o vivido através da ativação da memória possibilita reconstruir a atmosfera política da época, reacender emoções individuais e coletivas, convivências mútuas de companheirismo e de lutas.

Nós éramos muitas.

Tinha a D. Crizá. O grupo dela era um grupo forte. Dava muito apoio ao que as legionárias faziam. Tinha as da família Birico, algumas ainda estão aí. No Segundo Distrito tinha a esposa do Zé da Gravata. Ela faleceu, mas tem as filhas. Tinha a Marezi; a Mariel. Tinha a Raimundinha Lopes. Era um grupo forte, muito grande. Cada bairro tinha o seu grupo. Os grupos se juntavam e faziam o grupão[... . $]^{175}$.

Debruçar-se sobre o passado é reencontrar-se consigo mesmo como integrante de um tempo, salvo pela memória da perda total, e assim reconstruir a identidade. O passado é atualizado e presentificado.

A gente fazia comício onde podia fazer. Um coreto ou qualquer coisa. No caminhão. Nas colônias a gente avisava na sua colônia vai ser tal dia. [. . .] Quando elas (PTB) vinham a cavalo ou a gente mandava buscar também, ou buscava um caminhão. Tinha faixas, canções. A gente usava uma música de sucesso, que estivesse na crista da onda e botava os versos e mandava para os municípios. [...] Uma vez chamaram: olha elas do deputado macaxeira porque o José dava mandioca aos colonos para plantar. Sabe o que fizemos? Um macaxeiral. Houve até a passeata da macaxeira ${ }^{176}$.

\footnotetext{
${ }^{174}$ Ibid.,

${ }^{175}$ Ibid.,

${ }^{176}$ Ibid.,
} 
Evocar o passado para essas mulheres, na atualidade com 60, 70, 80 anos, foi uma atividade salutar. E, na escuta do outro, foi-nos possível penetrar num mundo de emoções e sentimentos retidos pela memória.

Relembrar é uma atividade mental que não exercitamos com freqüência porque é desgastante ou embaraçosa. [ . . .] Na rememoração reencontramos a nós mesmos e a nossa identidade, não obstante muitos anos transcorridos, os mil fatos vividos [. . .] Se o futuro se abre para a imaginação, mas não nos pertence mais, o mundo passado é aquele no qual, recorrendo a nossas lembranças, podemos buscar refúgio dentro de nós mesmos, debruçarmos sobre nós mesmos e nele reconstruir nossa identidade ${ }^{177}$.

Para Iriscélia Cabanellas, os acontecimentos da vida comunitária, as experiências da militância política como legionária, autonomista, naquele outro tempo, foram ressignificadas, adquiriram "novas cores".

Elas vestiam sempre branco [as do PTB] só que elas tinham um símbolo azul. O nosso era amarelo. Só que a organização do nosso grupo era maior, tinha mais peso e organicidade. Nós contávamos com a presença de D. Lydia, esposa do ex-governador Guiomard Santos que tinha muito vasto conhecimento. Tinha também muito dinamismo. Estava muito próxima de nós. A nossa organização era completa[. . . . ${ }^{178}$.

Mapear a cidade, o território, indo aos espaços sociais caracterizados pela penúria material e intelectual, era um exercício de formação de consciência social. Os "fracos de condição", os excluídos socialmente, estão presentes em suas lembranças.

D. Lydia dizia para não deixarmos as pessoas sofrendo em fila, nem no meio do sol, nem sendo humilhados. A recomendação era de que elas deviam ser bem atendidas. A gente dizia: D. Lydia na localidade tal tem tantas crianças sem escola - Como é o nome da pessoa que é dona daquela localidade ou do seringalista. E dizia construa uma escola lá que o Guiomard põe o professor. Nós vamos orientar e a escola vai funcionar. Era desse jeito[... $]^{179}$.

\footnotetext{
${ }^{177}$ BOBBIO, In: DELGADO, Lucília de Almeida Neves. História oral e narrativa: tempo, memória e identidades. História oral. Revista da Associação Brasileira de História Oral. São Paulo: FFLCH-USP, 2003, p. 16.

${ }_{179}^{178}$ CABANELLA, Iriscélia: depoimento [1 de julho de 2004]. Entrevistadora: Maria José Bezerra. Rio Branco.

${ }^{179}$ Ibid.,
} 
A experiência de ser legionária era participar de um sonho coletivo. Era acreditar num futuro promissor para o Acre frente às dificuldades sociais e econômicas que a região atravessava, devido o alongamento da crise da economia gomífera desde o final da Segunda Guerra Mundial.

O projeto de autonomia era muito esperado por todo mundo. Todo mundo sabia o que era autonomia do Estado. E além de ser esperado, o projeto por causa do que podia vir de bom para o Acre isso acendia a esperança dos acreanos. Nós também, levávamos informações para ele [Guiomard] para que ele pudesse compreender melhor[... . ${ }^{180}$.

$\mathrm{Na}$ visão política da professora Íris Célia Cabanellas, descendente de espanhol, nascida em Rio Branco em 1938 e desde os oito anos de idade presença constante nos palanques do PSD, Guiomard Santos, ao incorporar a mulher na luta pela autonomia, buscava legitimar esse ideal frente a sujeitos sociais que, na sua maioria, desempenhavam apenas os papéis domésticos tradicionais. "Despertá-las" para o jogo político da época em que, apesar do voto feminino, "política não era coisa para mulher", era possibilitar não uma ação pontual, comportamental, atitudinal, mas prepará-las para o exercício do poder.

O general dava muito valor a participação da mulher tanto na campanha dele quanto na administração. Quando ele empossou a Maria Angélica para o Departamento de Educação. Ele dizia que confiava nela porque confiava na força da mulher. E, realmente, a gente tinha D. Maria Angélica como símbolo. ${ }^{181}$

O ativismo político de trabalhar para os partidos, participar de reuniões, campanhas, ajudar pessoalmente os candidatos na conquista de votos sofria as interferências das peculiaridades da região. $\mathrm{E}$, frente a estas, o rádio era o instrumento que possibilitava o contato com o "mundo lá de fora", onde as coisas aconteciam... O rádio nesse contexto era muito mais que um mero aparelho de comunicação. 
A gente não viajava. A gente acompanhava através do rádio. Não fomos ao Congresso Nacional porque era no Rio de Janeiro. Não tinha estrada. Avião era só a FAB e era muito difícil. Mas ele [Guiomard Santos] nos mantinha atualizadas. Ele mandava cartas, dizendo onde esteve, com quem falou. Dizia tudo, o que rebateu. Ele escrevia muito para o Ivo Aguiar. A gente acompanhou todos esses momentos dele, os de euforia e os de tristeza, quando alguém fazia crítica ao projeto. ${ }^{182}$

O papel do líder também está presente nas lembranças de Iriscélia Cabanellas.

Daquele que luta e sofre, alegra-se e se entristece, mas mantém firme o ideal político. A memória registra as imagens, os sentimentos e a afetividade, demonstrando o jeito feminino do fazer político.

E cada vez que ele vinha, a gente ia recebê-lo no Aeroporto, onde é hoje o Aeroporto Velho [Estação de Passageiro Aeroporto Salgado Filho] e nós fazíamos todo o trajeto trazendo Guiomard nos braços. Era muita gente. Éramos sempre alimentados por esta idéia de autonomia, pela esperança de uma coisa que ia acontecer e que era muito importante para o Acre e que dependia daquele homem, além do líder que ele era. $\mathrm{O}$ grande amor que os acreanos tinham por ele, um sentimento de gratidão inabalável pelo governo que ele fez. ${ }^{183}$

Ao fazer um balanço da luta empreendida, a maioria de nossas depoentes tem o mesmo posicionamento de Iriscélia. Sem a emancipação política, o Acre continuaria sendo "colônia" do Brasil.

Valeu a pena ser Estado. Primeiramente porque adquirimos um outro conceito de cidadão, de cidadania. Os poderes constituídos, as lutas que nós enfrentávamos, inclusive depois disso, quando já éramos autônomos. É bem verdade que o desenvolvimento esperado ainda não chegou, daquela maneira que nós queríamos, mas de certa forma, nós tivemos autonomia para criar nossas instituições. Acho que algumas cabeças que passaram pela administração não foram proveitosas e isso prejudicou de uma certa forma $o$ Estado. Tivemos também algumas cabeças privilegiadas. ${ }^{184}$

${ }^{182}$ Ibid.,
${ }^{183}$ Ibid.,
${ }^{184}$ Ibid., 
Ao evocar o passado, a luta das mulheres para o Acre ser Estado, D. Alegria Abdala Isper, descendente de sírio, que começou a vida no Acre regateando pelos rios juntamente com o marido, Abrahão Isper, narra o vivido: "O Acre tinha que crescer, tinha que desenvolver. Como tudo, trouxe bem e mal. Hoje nos temos universidade, nós temos escolas, temos estradas, temos ligação com todo mundo. ${ }^{185,}$

Mais do que relembrar, refez o passado num contexto em que a autocrítica e/ou a crítica estão presentes.

Enquanto para Ana Carneiro Paes, “D. Inglesinha”, militante ferrenha do PTB, torcedora fanática do Vasco e primeira mulher de Rio Branco a trabalhar num estabelecimento bancário (1935), o Banco da Amazônia, tendo sido, inclusive, Presidente do Comitê Feminino das legionárias do PTB, ser legionária era ser partícipe dos embates políticos da época, era integrar as fileiras dos que se moviam no campo minado da política, ora aguerridamente, ora de forma irônica, onde havia lugar também para as brincadeiras, as zombarias, o companheirismo, o riso. . .

Tinha comício. A gente usava letra de música. Essa coisa né? Nos caminhões, iluminava os caminhões, botava os altos falantes e botava a música. Tinha torcida, bandeirola, faixa. O povo gostava. Eu fui Presidente do comitê feminino das legionárias do PTB. Havia agressão verbal, física não. Nos municípios houve morte. Muitas vezes a gente se encontrava [com as legionárias do Guiomard] na subida da escadaria. Eu encontrava por exemplo a Ivinha do Geraldo Mesquita, aí quando ela me via metia o barco embora, aí dizia agora tu é que vem prá cá, eu dizia tu é que vem pra cá e explicava, senão dava briga[... . ${ }^{186}$.

Partilhar o mesmo espaço significava perceber a luta política, como constituinte e constituída, a partir das condições concretas de vida, das opções ideológicas, dos interesses de classe, de partido. "Eu tinha uma parente, que era lá do partido dele, me encontrava - vem pra cá, aí eu dizia: Tu é que vem pra cá comigo. A Ivinha, cansei de encontrar nesse Triângulo

\footnotetext{
${ }^{185}$ ISPER, Alegria Abdala: depoimento [18 de junho de 1996]. Entrevistadora: Maria José Bezerra. Rio Branco. ${ }^{186}$ PAES, Ana Carneiro (D. Inglesinha): depoimento [19 de abril de 1996]. Entrevistadora: Maria José Bezerra. Rio Branco.
} 
fazendo campanha pro Geraldo Mesquita e eu pro Oscar Passos. Aí a gente parava, brincava, zombava. ${ }^{187,}$.

Lydia Hammes Guiomard Santos, esposa, companheira e militante do PSD, que embora não residindo permanentemente no Acre, vinha sempre a Rio Branco, sobretudo durante o período das campanhas políticas e, notadamente nos anos de 1961 e 62 - momentos decisivos da tramitação do projeto de elevação do Acre a Estado, liderou as ações políticas das legionárias do PSD. "Eu cuidava da correspondência dele. Ele [Guiomard Santos] às vezes estava muito ocupado e, como tinha muita identidade com ele, comecei exercendo algumas atividades, pois eu estava a par de muita coisa dele. Eu sabia que tratamento dar" ${ }^{\text {"188. }}$.

No faz-e-refaz das memórias das legionárias, o passado é revivido não de forma linear e harmônica, mas incorporando o conflito, emitindo juízo de valor, enveredando em vários caminhos. "Havia fraude nas eleições. Nós íamos pra lá ouvir a votação. A urna era toda fechada. Aí um dia, uma disse [legionária]: Tão fazendo coisa no voto. Foi um escândalo. Foi um sururu, precisava ver. Na apuração de votos a gente tinha que observar muito. ${ }^{189,}$

Na dinâmica de relembrar, D. Lydia Guiomard Santos reconstitui o passado através de referências, como o tempo da eleição. Tempo ido, mas não perdido, pois retido pela memória pode ser revivido.

Na eleição, eu ia para a casa da Crizá. Nós cozinhávamos de manhã até meio dia. Éramos as últimas a votar porque era um panelão desse tamanho, porque eles sabiam que lá a comida era boa. Lá no porão de baixo tem cama, quarto, levavam as crianças e tudo mais. Você sabe, prá gente pobre dia de eleição é dia de festa, pediam muito. Para a população rural, dia de eleição era uma festa.

\footnotetext{
${ }^{187}$ Ibid.,

${ }^{188}$ SANTOS, Lydia Hammes Guiomard: depoimento. [8 de maio de 1996]. Entrevistadora: Maria José Bezerra. Rio Branco.

${ }^{189}$ Ibid.,
} 
A narrativa reconstitui a vivência política da época, o controle que os caciques políticos - Guiomard Santos e Oscar Passos - exerciam sobre o eleitorado. São trajetórias marcadas por um fazer político caracterizado pelo clientelismo, pelo "guiar" o povo.

Um dia, a gente tava lá na casa da Crizá, a Lavocat. Lá a gente fazia faixas, inventava canções. . . O José [Guiomard Santos] dava muita disciplina. Uma vez foi marcado nosso comício e o Passos [Oscar Passos - PTB] tinha marcado também. Então nós tínhamos que atravessar o caminho onde estava o diabo do comício do Passos, lá do outro lado. Aí houve uma reunião muito séria das pessoas para vigiar, para tomar conta das pessoas mais exaltadas porque elas lá do Passos provocavam muito.

Essas memórias das lutas das mulheres do Acre nos permitem perceber o processo de constituição delas como sujeitos políticos a partir de posicionalidades fragmentadas e contraditórias. Posicionalidades estas construídas socialmente e portadoras de significados sociais.

As legionárias eram mulheres, mães, esposas, algumas professoras, algumas funcionárias públicas e uma grande maioria donas de casa que, através do PSD e PTB, ousaram sair do "casulo" e adentraram a cena política com visibilidade pública.

Com suas narrativas carregadas de emoção, revisitaram experiências passadas, cruzando o tempo individual com o tempo social, a partir de um "olhar" feminino.

Progressistas ou conservadoras, chamadas à luta a partir de propósitos, expectativas e direcionamento dos chefes políticos locais, Guiomard Santos e Oscar Passos, as legionárias se constituíam um "exército combatente" de grande valia para disseminar o ideal autonomista.

Mobilizaram, panfletearam, discursaram, brigaram, sonharam e apostaram na causa do Acre-Estado.

Ao trazerem o debate da luta pró-autonomia para o seio de suas famílias, fortaleciam, mesmo as que eram contrárias (as do PTB), o projeto do Guiomard Santos, o movimento próEstado do Acre. 


\section{CAPÍTULO 3 Os PARTIDOS POLÍTICOS E A MEMÓRIA DOS MILITANTES ACREANOS}

No Acre, o PSD era elite econômica e a UDN era a elite intelectual. Já o PTB era peixe pequeno, só comia pelas beiradas.

Aníbal Miranda

Ao reconstruirmos o processo de invenção do Acre emancipado, torna-se necessário trazer à tona as lembranças e as imagens dos integrantes dos partidos políticos da época: PSD, PTB, UDN e PCB. Este último tinha também seus simpatizantes e militantes, embora raramente agissem "à luz do dia" frente à situação de clandestinidade do Partidão pós-1947. Muitos que integravam as fileiras do PTB no Acre na verdade eram mais pecebistas que petebistas.

No entanto, para que as falas dos nossos depoentes possam ser melhor significadas frente aos contextos nacional e local, é mister caracterizarmos, em linhas gerais, o quadro político-partidário brasileiro de 1945 a 1962, quando o Acre foi elevado à categoria de Estado.

Nesse caso, apoiamo-nos na produção historiográfica existente, mormente em Maria Victoria de Mesquita Benevides, com seu trabalho "O Governo Kubitscheck Desenvolvimento Econômico e Estabilidade Política: 1956 - 61”, e, sobretudo, na obra de Vasmireh Chacon, "História dos Partidos Brasileiros", por apresentar este último uma visão mais abrangente das agremiações partidárias brasileiras no período em tela. A partir dos contribuintes desses autores, elaboramos uma síntese do quadro político partidário brasileiro nacional como palco para as falas dos velhos militantes acreanos. 
3.1 - Os partidos políticos brasileiros em foco

De 1945 a 1962, o contexto nacional era de grande ebulição frente ao confronto entre duas tendências ideológicas - o populismo com variantes e o liberalismo com suas divisões internas.

Em 1945, com o término da Segunda Guerra Mundial e a conseqüente vitória dos países aliados (França, Inglaterra e os E. U. A) e posterior "Guerra Fria", no Brasil cresceu a oposição a Getúlio Vargas, cujo governo era identificado ideologicamente com o "nazifascismo".

Com uma sociedade civil ainda insuficiente enquanto força de pressão política, coube aos militares retornados dos campos de batalha da Itália a construção do discurso de que a guerra trazia como reflexo ideológico a luta pela sobrevivência e a "purificação" da democracia. Foi em nome dos princípios liberais e democráticos que o Brasil, aliado aos E.U.A, tinha ido à guerra e lutado ao lado não só de britânicos e franceses, mas até dos soviéticos. O discurso salvacionista patriótico das Forças Armadas, presente desde a proclamação da República, passa a ganhar maior visibilidade e força política. Fora do Exército não havia salvação.

E, nesse contexto, ganha peso a candidatura do Brigadeiro Eduardo Gomes e posterior a do Ministro de Guerra, Eurico Gaspar Dutra, um de tendência liberal saído das fileiras do tenentismo e o outro representante das forças políticas mais conservadoras e que tinha sido apoiador do Estado Novo. Porém, a existência das duas candidaturas expressava a divisão interna que existia no seio das Forças Armadas.

Frente ao impasse, a "saída" deu-se com a deposição do Presidente Vargas, em outubro de 1945. 
Diante do quadro nacional, a esquerda, representada pelo PCB, também admitia que a solução política para o Brasil era a democratização. Em 1945, nas eleições presidenciais e constituintes, o PCB obteve uma expressiva votação, na medida que praticamente tinha 10\% do eleitorado, um senador e 14 deputados federais. Mas, no movediço campo político, começa a se fragmentar a aliança antifascista.

E, a partir de 1947, com o bloqueio soviético a Berlim Ocidental, a organização do Escritório de Informações dos partidos comunistas, o qual sucedeu a Internacional Comunista que se extinguiu durante a Segunda Guerra Mundial, os expurgos stalinistas e a guerra da Coréia em 1950, a ambiência política brasileira começa a atingir altas temperaturas e, num universo marcadamente anticomunista, a questão central era o fechamento do PCB, embora este, no seu programa, expressasse a não inclusão dos princípios marxistas leninistas, mas sim uma convocação à unidade nacional, à democracia e ao progresso da pátria.

Várias vozes se levantaram contra o projeto de cassação tanto de parlamentares quanto do registro do PCB, como Francisco Sá Filho, Erico Veríssimo, Afonso Arino de Melo Franco e até ex-interventores e chefes de polícia como Agamenon Magalhães e Etelvino Lins, pessedistas e udenistas como Arthur Atélio Viváqua e Arthur Santos, Ferreira de Souza, Aluísio Carvalho e o socialista Hermes Lima, entre outros expoentes da cultura e política nacional.

No entanto, as forças a favor da cassação dos mandatos eram mais poderosas e nesta incluíam-se nomes como o Vice-Presidente Nereu Ramos, o Presidente da Câmara dos Deputados Daniel de Carvalho, o Ministro da Justiça Adroaldo Mesquita da Costa, o chefe da Casa Civil Pereira Lyra e o Ministro da Agricultura, Daniel de Carvalho.

Os ares da liberdade política começavam a ser sombreados.

E o PCB, nesse contexto, endureceu a crítica e a denúncia. Através do Manifesto Agosto, conclamava às greves, denunciava as eleições sindicais, defendia a luta pela 
libertação nacional e a instauração de um governo democrático popular e através de seus periódicos, como a Revista Problema - publicação doutrinária do Núcleo Dirigente, disseminava várias palavras de ordem dos líderes soviéticos, as quais foram depois consideradas excessivas por Astrogildo Pereira, na Imprensa Popular, a partir de 1956, com a desestinalização.

Internamente, as dissidentes começaram a surgir no PCB. Alguns defendiam a luta armada, enquanto outros, como Jacob Gorender (Voz Operária) e Apolônio Carvalho, colocavam-se contra, na medida que a tendência que se tornará majoritária defende o gradualismo em oposição às posições golpistas do esquerdismo, sendo esta considerada reformista ou mesmo revisionista.

Paralelamente à luta contra o PCB, aumentava também a resistência ao populismo, e o poder passa efetivamente a gravitar em torno de três grandes agremiações partidárias: PSD, UDN e o PTB.

No campo minado em que tinha se transformado a política nacional, o PSD usa a flexibilidade ajeitando, minorando, aliando-se, buscando "adaptar-se" ao novo momento político, enquanto a UDN demonstra no discurso e na práxis menor capacidade de adaptação. O caráter antipopulista desta começa a adquirir "fortes cores".

No entanto, esta passa a se mostrar menos a favor do liberalismo que do populismo, tendo em vista que o populismo era entendido por seus ideólogos e militantes como uma política de massa, caracterizada pela ausência ou limitação de agregação de interesses e participação classista, possibilitando que líderes carismáticos se apossassem do poder utilizando as massas para sustentá-los, não havendo, portanto, espaço político para a livre representação dos interesses de classe. 
O controle social, de cima para baixo, seria exercido pelo Estado corporativo, "cartorial", capaz de dissolver os antagonismos sociais e dificultar a livre expressão dos interesses de classe.

Nesse universo, a classe média tradicional não acata nem esta nova posição paternalista, preferindo a forma paternalista usual.

Miltom Campos, expressão genuína da UDN, sintetiza a dualidade liberalismo versus populismo ao enfatizar: “A UDN não é exatamente uma agremiação liberal, mas inspirada na doutrina liberal, temperada pelas soluções da moderna democracia que adota em seu programa e nos seus princípios. Com isso quero significar que se a UDN tem a preocupação da liberdade, ocupa-se igualmente da igualdade"190.

Segundo Chacon (1981, p. 151), o programa da UDN de 1945 era liberal, assumindo certa conotação social em 1957, no que pese a "quebra de braço" entre as correntes que a integravam: "os bacharéis", os "realistas" e os que defendiam uma maior "tecnificação da política econômica", na direção de certas tendências tenentistas que "desaguaram" na doutrina da Escola Superior de Guerra.

Destaca-se ainda que, quando da sua fundação, havia mais unidade no seio da UDN, aprofundando-se

[. . . ] as divergências em decorrência de novos fatores e tendências, dentre os quais podemos citar: oligarcas destituídos politicamente em 1930 (os Nery no Amazonas, os Konder em Santa Catarina, os Caiado em Goiás, os autonomistas baianos com Otávio Mangabeira a frente [e outros], antigos "perrepistas" e de certo modo Gilberto Freire, assessor imediato do Governador Estácio Coimbra deposto em 1930 [ . . ] Terrentistas militares e civis os Távora no Ceará, José Américo de Almeida, sucessor de João Pessoa, Carlos de Lima Cavalcanti, governador revolucionário de Pernambuco em 1930, Juraci Magalhães e outro tanto na Bahia, [dentre outros], liberais convencionais como Prado Kelly, Armando de Sales, Milton Campos, Júlio de Mesquita Filho [dentre os nomes mais expressivos] $]^{191}$.

${ }^{190}$ CHACON, Vamireh. História dos partidos políticos. Brasília: Unb, 1981, p. 151.

${ }^{191}$ Ibid., p. $151-152$. 
Importante considerarmos que a representação da UND cresceu significativamente no Nordeste e Norte, além de contar com políticos de grande envergadura no Sudeste e no Sul.

Nesse contexto, a UND tinha se transformado numa "Torre de Babel". Embora em termos gerais, sua direção apontasse para uma posição de centro-direita, todavia a maior força política ainda era o PSD. Aliás, após a eleição do Presidente Dutra, em dezembro de 1945, surgiu a proposta da aliança PSD-UDN, o que se constituía numa oportunidade para os udenistas de participarem do poder, frente ao afastamento deste, desde o Estado Novo, enquanto os partidos menores orbitavam em torno do PSD ou da UDN.

Assim sendo, a Presidência do General Eurico Gaspar Dutra decorreu com certa normalidade, exceto no que se refere à cassação do PCB. No entanto, com o retorno triunfal de Vargas, o combate mordaz de representantes da UDN se fez sentir de forma contundente, seja através de Carlos Lacerda ou do Jornalista Amaral Neto, acrescido do fato do estabelecimento de laços cada vez mais estreitos entre a UDN e os militares. E embora Vargas tivesse concedido aos udenistas certa participação na estrutura administrativa, como José Américo, a crítica virulenta a este continuava de forma implacável.

Com a saída de Vargas do poder e a posterior gestão de Café Filho na Presidência da República e, sobretudo, diante da linha política imprimida ao seu governo - liberalismo udenista de direita com apoio militar -, a coligação PSD-PTB se fortaleceu e conseguiu eleger Juscelino Kubitschek presidente e João Goulart vice, com o destaque de este ter recebido mais votos do que aquele.

Esta aliança, mais do que um acordo para ganhar as eleições se configurava a formação de uma espécie de "frente nacional” que incluía desde integrantes da burguesia nacional (industrial e frações da comercial), a classe média progressista e o proletariado. 
A partir de então, na prática, fortaleceu-se a estratégia do "toma lá, dá cá" — o PSD ficava com o Banco do Brasil e os Ministérios da Justiça, Viação e Obras Públicas, e o PTB com a Previdência Social.

No entanto a posterior eleição de Jânio Quadros, tendo João Goulart como vicepresidente, e a conseqüente oposição e temor dos grupos políticos conservadores de que Goulart no poder "desse uma guinada para a esquerda" fizeram com que numa "solução pelo alto", fosse implantado o parlamentarismo, tendo-se Tancredo Neves como PrimeiroMinistro.

Diante do quadro político e social de instabilidade, tanto o PSD quanto a UDN fizeram mudanças em suas cartas de princípios. O PSD passa a adotar um caráter mais reformista e a UDN, dar cor ao seu ideário com nuances socializantes. E, à medida que o populismo ia cada vez mais caracterizando o quadro político nacional, ocorreu a formação de frentes extraparlamentares e extrapartidárias, levando mais adiante ao surgimento da Frente Parlamentar Nacionalista, composta fundamentalmente por senadores e deputados, e o Movimento Popular de Libertação, liderado pelos governadores Mauro Borges e Miguel Arraes.

Contrapondo-se à "onda populista", os grupos políticos conservadores de direita se aglutinavam no IBAD (Instituto Brasileiro de Ação Democrática), do qual emergiu a Ação Democrática Popular (ADEP), com fins eleitorais e núcleo de sustentação da Ação Democrática, representada pela sigla (ADEP), e sobre todas essas organizações pairava o Instituto de Pesquisas e Estudos Sociais (IPES).

Agravando o contexto, em torno do IBAD gravitavam os grupos de extrema direita, que com um discurso extremado e violento defendiam a Ordem. Entre estes, destacavam-se a Liga Democrática Radical (LIDER), a Patrulha Auxiliar Brasileira (PAB) e o clandestino e de tendência terrorista Comando de Caça aos Comunistas (CCC), o GAP (Grupo de Ação 
Patriótica). Estes dois últimos, de caráter nitidamente paramilitar, e a Sociedade Brasileira de Defesa da Tradição, Família e Propriedade (TFP), com possível ligação com a Cruzada do Rosário em Família, cuja matriz ligava-se ao movimento organizado pelo padre norteamericano Peyton, na oportunidade em trânsito no Brasil, a Marcha da Família com Deus pela Liberdade e o Movimento de Arregimentação Feminina.

Portanto, o quadro político-partidário brasileiro estava inquietante. A sociedade tinhase fragmentado. A democracia representativa estava em cheque. Nesse universo, posições golpistas se fortaleciam como a "saída" para o impasse.

Diante do crescimento da "onda populista", os partidos engrossavam ou diminuíam as suas fileiras de congressistas. “O PSD, que tinha 177 congressistas em 1945, caíra para 141, o PTB pula de 24 para 136 e até o PSP passa de 2 para nada menos que 23. Mas, em compensação, a própria UDN aumentara de 87 para 110, aumentando, também, suas linhas auxiliares: o PDC de 2 para 19 e o PL de 1 para 5, além dos partidos menores (PTN, PST, MTR, PSB e PRT) dispostos a qualquer tipo de coalização atraente" ${ }^{, 192}$.

No entanto, a possibilidade golpista era temida - por conta dos resultados que poderia acarretar - pelos que ainda acreditavam na democracia representativa, particularmente o PSD, a UDN e o PDC.

E, na perspectiva de contemplar os anseios e reivindicações dos vários segmentos da sociedade brasileira, o PSD reformulou seus programas em 1945, 1946 e 1962, a UDN em 1945 e 1957e o PDC em 1945 e 1961.

A perspectiva para o PSD era apostar no que chamavam vagamente de "educação política do povo", formar uma consciência democrática, entendendo a democracia não apenas como regime de governo, mas como estilo de vida; o respeito e a vigilância constitucional; e serenidade e elevação nas campanhas e debates diante do clima "acalorado" dos embates políticos, sem no entanto apresentar propostas de como o Estado seria democratizado e

${ }^{192}$ Ibid., p. 158. 
tornado mais eficiente e mais social. No seu ideário cabia a uma elite intelectual "iluminada" dirigindo o Estado, efetuar as mudanças. Era a concepção de uma "revolução conservadora", da "mudança pelo alto".

Em 1946, reforçando o papel do Estado, enfatizavam que o Estado de Direito deveria assegurar ao cidadão a inviolabilidade dos direitos relativos à liberdade, domicílio, subsistência, segurança individual e propriedade.

O Estado assume nessa visão um caráter místico, salvacionista, que se expressa na prática política das oligarquias dominantes. Cabia ao Estado reduzir as diferenças sociais, proporcionar iguais oportunidades, segurança e bem estar para todos e no aspecto econômico orientar e estimular a iniciativa privada, criando um ambiente propício para o seu desenvolvimento. A "saída" da crise estava nas mãos do Estado paternalista.

Com a mesma visão estatal também defendiam o amparo às instituições beneficentes, as diversões dos trabalhadores rurais e urbanos e o incentivo ao cooperativismo.

Em relação à opção pelo presidencialismo ou parlamentarismo, o PSD não se pronunciava, optava por propor uma reforma eleitoral que viabilizasse um ou outro e quanto aos abusos econômicos defendia uma legislação antimonopolista que na prática se mostrou inócua, sendo os investimentos do capital estrangeiro vistos de forma ambígua - necessários porém com a adoção de normas disciplinadoras e a reforma agrária, principal reivindicação da massa camponesa era vagamente recomendada, porém obedecendo ao preceito da Constituição quanto à justa distribuição da propriedade, com igual oportunidades para todos. E no que se referia à política externa embora enfatizasse a necessidade de o Brasil adotar uma linha de independência, destacava que não deveria prejudicar os compromissos relativos à defesa da solidariedade com o mundo ocidental, cristão e democrata, o que, na prática, conduzia a uma postura de fidelidade à política externa norte-americana. Ambigüidades $e$ ambivalências caracterizam o discurso pessedista. 
Enquanto a UDN, fiel ao postulado do liberalismo, defendia que a realidade democrática seria atingida através do efetivo exercício das liberdades em todas as suas manifestações - reunião, associação, ensino, religião, culto sindical, organização partidária -, enfatizavam também a necessidade da autonomia sindical, contrariamente à tendência verticalizada vinda desde o Estado Novo e à redução da intervenção estatal que deveria limitar-se à elaboração de planos de desenvolvimento que se coadunassem com os interesses das classes ou para suprir as deficiências das organizações econômicas, ou, ainda, para garantir a segurança e os direitos da produção intelectual e manual.

Por outro lado, ressaltavam também que o Estado deveria fazer por merecer a confiança da sociedade dando o exemplo do uso racional, moral e ético dos recursos da nação, mantendo o equilíbrio orçamentário, contendo a inflação, moralizando as despesas evitando as desnecessárias ou supérfluas.

Fiel ao seu ideário liberal, a UDN não só aceitava o capital internacional como apelava a este, pois o considerava necessário aos empreendimentos nacionais e ao aproveitamento das reservas inexploradas, manifestando ainda certa preocupação com o desenvolvimento científico e tecnológico.

Em relação à política externa, advoga a posição de que o Brasil deveria adotar uma posição cordial, porém independente dos E. U.A.

A partir de 1957, a UDN passa, também, a se preocupar com a questão das classes sociais. "A UDN não é um partido de classe. Luta pelo bem-estar de todo o povo e pelo direito dos fracos. Em defesa do povo como um todo, não é um partido populista, é um partido popular"193. E, contrariamente ao PSD, dá ênfase aos grupos sociais intermediários entre o indivíduo e o Estado, como a família, a Igreja e demais comunidades religiosas, aos sindicatos, livres e autônomos perante o poder público e o paternalismo patronal, ou ainda, à intervenção político-partidária; as cooperativas, cujos raios de ação deveriam atingir as zonas

${ }^{193}$ Ibid., p. 164 
rurais, e quaisquer associações de fins lícitos que visem a educação, a defesa dos interesses coletivos e a ascensão do homem aos plenos direitos e responsabilidades.

No entorno do PSD e UDN, existiam os pequenos partidos, como o Republicano Mineiro, chefiado pelo ex-presidente da República, Artur da Silva Bernardes, cujo programa apresentado em 1951 não destacava nenhuma causa nova - muito pelo contrário consagrava as existentes -, e o Partido da Representação Popular, de orientação integralista, que, alinhado a política externa norte-americana na luta contra as novas formas do imperialismo totalitário, proclamava a sua adesão ao regime democrático representativo. Sua cassação foi solicitada ao Tribunal Superior Eleitoral por representantes dos liberais e socialistas, mas estes não foram atendidos; o Partido Libertador, liderado por Raul Pilla, cujo programa aprovado em 1945 foi revisado em 1947 e que tendia a aliar-se com a UDN, de tendência liberal, defendia o parlamentarismo, o liberalismo econômico e a democratização econômica. Pacifista, acreditava nos poderes da ONU para manter a paz mundial. Também enfatizava a liberdade sindical, o direito de greve, a pesquisa científica e técnica; e o PDC, Partido Democrata Cristão, que tinha como fundamentos principais: o sufrágio universal, a autonomia e respeito recíproco dos Poderes Legislativo, Executivo e Judiciário, a responsabilidade dos detentores do poder e a mais ampla publicidade de seus atos. À medida que crescia, o PDC modifica o seu triplo fundamento para popular, democrático e cristão. Importante destacarmos que o PDC brasileiro surgiu numa conjuntura internacional marcada pelo movimento da Democracia Cristã na Itália, Alemanha, Áustria, França.

O PDC foi criado por Cesarino Júnior, professor de Direito do Trabalho da USP e seu programa inspirado por Alceu Amoroso Lima. Buscava se constituir numa terceira força política alternativa distinta tanto do liberalismo quanto do marxismo e colocava-se, posteriormente, como defensor do nacionalismo econômico e antiimperialista. 
No campo das idéias socialistas, havia o Partido Socialista Brasileiro (PSB), que, embora tenha sido nas suas origens incipientemente operário, passou, anos depois a ser dirigido por intelectuais e ter um discurso centralizado na classe média.

Esse fato explica por que a Esquerda Democrática teve a sua origem vinculada a egressos da UDN e da União Democrática Socialista de São Paulo - esta última formada a partir de grupos políticos que clandestinamente desde 1943 vinha se organizando, tendo como base inicial a política estudantil da Faculdade de Direito, constituindo-se numa espécie de frente à ditadura varguista.

A sua composição incluía:

[. . .] os esquerdistas mais radicais, incluindo no seu seio, o Grupo Radical de Ação Popular (GRAP), mas, também, liberais, que se ligarão aos futuros udenistas, inclusive por interesse de classe e que eram, então, membros do Partido Libertador Acadêmico. O que almejava a UDS, conforme seu manifesto de 1945, defendia a efetiva democratização do país e a instauração do socialismo $^{194}$.

Frente ao exposto, o manifesto da Esquerda Democrática em 1945 assinalou a sua saída da UDN e a formação do Partido Socialista Brasileiro. Seu programa estabelecia que ela não se constituía num partido político, mas que logo se transformaria num deste. De conteúdo liberal, defendia o sufrágio universal direto e secreto, com representação proporcional; liberdade de pensamento em todas as formas de manifestação; direito de greve e autonomia sindical, porém não reivindicava nem a socialização democrática nem a autogestação dos meios de produção ou a sua inicial estatização. Era mais liberal que socialista.

Enfatizava, ainda, a relevância das conquistas liberais-democráticas, como estágio político para a eliminação da exploração do homem pelo homem, e admitia que algumas de suas reivindicações dar-se-iam nos marcos do capitalismo, mas a solução real e definitiva dos

${ }^{194}$ Ibid., p. 170. 
problemas sociais como a reforma agrária, a industrialização e a democratização da cultura e da saúde pública só se daria com a realização cabal de seu programa. Não se constituía num partido de classe, pois não se destinava a lutar pelos interesses exclusivos de uma classe, mas de todos os que viviam do próprio trabalho. No entanto, não ficava indiferente à defesa dos interesses de pequenos produtores e comerciantes.

De todas as seções estaduais do partido, a mais ativa era a de São Paulo, cuja militância contava com a presença de Antônio Cândido e Flávio Abramo, entre outros, em geral jornalistas, que em seus artigos repudiavam o capitalismo de Estado, notadamente o nacionalismo soviético e o imperialismo armado, que tinham se concretizado no Estado totalitário russo. Não aceitavam a participação dos trabalhadores nos lucros da empresa, na medida que tal fato resultaria na universalização do capitalismo, por não alterar a estrutura econômica capitalista e sua conseqüente transformação no socialismo.

Com a sua política de antecipações, afirmavam a necessidade da

[. . .] socialização imediata de todas as fontes de adubos minerais, bem como a formação de uma vasta rede de estações de melhoramento, a climatação e genética para o fornecimento de sementes selecionadas, além da constante preocupação com a questão agrária, fazendo com que, a partir de 1949, passasse a defender a urgência de serem criadas ligas mutualistas de defesa das reivindicações econômicas, associativas e culturais, com vistas a extensão dos direitos da legislação trabalhista ao campo, e a formação de cooperativas socialistas ${ }^{195}$.

Essa idéia floresceu na década de 1960, na zona açucareira de Pernambuco, quando da pendenga jurídica entre os trabalhadores rurais e os proprietários do Engenho Galiléia, levando à formação das Ligas Camponesas lideradas por Francisco Julião, deputado estadual eleito pela legenda do PSB, e à posterior sindicalização rural católica empreendida pelo padre Antônio Melo, Vigário do Cabo, e por D. Eugênio Sales, na época Bispo Auxiliar de Natal, no contexto do Movimento de Educação de Base (MEB).

${ }^{195}$ Ibid., p. 173 
Nesse universo que caminha para a radicalização, o PSD também se constitui num baluarte na luta contra a Lei de Segurança Nacional e contra o Partido de Representação Popular, celeiro dos integralistas, e da maneira geral contra toda forma de fascismo.

Ao passo que o PTB (Partido Trabalhista Brasileiro) até 1945 se apresentava como a terceira força política de expressão eleitoral, porém era o partido que mais crescia, passando de "24 parlamentares em 1945 para 136 em 1962"196.

Considerado por seus adversários "um corpo sem cabeça", seguia em linhas gerais os postulados do trabalhismo inglês, em voga pós Segunda Guerra Mundial e, neste caso, em suas idéias mestras entendiam, nas palavras do Senador Gaúcho, Alberto Pasqualini, que

a economia socialista era uma técnica e não um fim. Poderá dar eventualmente, bons resultados em países evoluídos social e materialmente, mas daria resultados negativos em países como o nosso, que figura entre os mais atrasados do planeta. Será desnecessário esclarecer que nos referimos aqui a um socialismo do tipo trabalhismo inglês e não as outras formas de socialismo. [. . . ] na Inglaterra, o trabalhismo é socialista. No Brasil [.. .] devemos permanecer no sistema de iniciativa privada, isto é, capitalista ${ }^{197}$.

Nesse aspecto, não diferia do PCB, como assinala seu programa de 1945, pois acreditavam que "o problema econômico imediato do Brasil ainda é o fortalecimento do capitalismo nacional, pois o proletariado sofre mais da debilidade do capitalismo do que do próprio capitalismo" ${ }^{, 198}$.

Posteriormente, o conteúdo programático do PTB sofreu alterações a partir do discurso de Sérgio Magalhães e da práxis de Leonel Brizola, deputados federais petebistas, tendo como instrumento a Frente Parlamentar Nacionalista e defendiam a

democratização constitucional (com reformas constitucionais e da capacidade legal de mobilização partidária e popular); democratização do ensino e da cultura ([para] combater o analfabetismo e fortalecer a escola

\footnotetext{
${ }^{196}$ Ibid., p. 175.

${ }^{197}$ Ibid., p. 175.

${ }^{198}$ PCB (Processo de Cassação de Registro: 1947), p. 99 Apud CHACON, op. cit., p. 175.
} 
pública e a universidade); reforma agrária (para efeito de permitir a desapropriação por interesse social, mediante indenização pelo valor fiscal com o pagamento em títulos da dívida pública e legalização das associações camponesas; abastecimento e custo de vida (combate ao monopólio privado, mais estatizações e suporte creditício às atividades produtivas; desenvolvimento econômico independente, estatização também do monopólio cambial, do comércio externo, do crédito em geral, da pesquisa geológica e exploração de riquezas minerais, bem como extensão do planejamento ao nível nacional e defesa das empresas brasileiras restantes ) e finalmente política externa independente ${ }^{199}$.

Sérgio Magalhães e a maioria da Frente Parlamentar Nacionalista almejavam mudanças sociais, porém nos limites da lei, da Constituição. Por outro lado, há uma grande preocupação deste e outros integrantes da FPN de caracterizar o que entendia por esquerdista e neste conceito agrupar comunistas, trabalhistas, socialistas e até católicos, acentuando também que ser esquerdista não era ser marxista, na medida que as esquerdas brasileiras não defendiam a socialização dos bens de produção. A reivindicação central das esquerdas era pelo revigoramento da democracia, aperfeiçoamento das leis sociais, as reformas de base e as constitucionais, porém a ambigüidade do discurso da FPN e do próprio João Goulart é que se apresentavam ao mesmo tempo como governo e como oposição.

A perspectiva dos petebistas era mais pela dignificação do trabalho circunscrita aos limites do social democratizante do que pelo socialismo propriamente dito.

Mais adiante, em meados dos anos 50, surgiu o Movimento Trabalhista Renovador, que se apresentava como "entidade cívico-apartidária", formada basicamente por parlamentares defendendo a moralização dos costumes, dos serviços públicos e fazendo críticas severas ao suborno, à mentira, ao empreguismo. Ressaltavam que queriam mudanças em profundidade no que se referia à reforma agrária, à democratização da educação e, no campo da Previdência Social, à unificação do seguro social e à criação do seguro desemprego e à industrialização.

${ }^{199}$ CHACON, Op. Cit. p. 177. 
Outro grupo minoritário surgido na época do aparecimento do PTB que se apresentava como trabalhista era o Partido Popular Sindicalista, que se transformou no Partido Social Progressista de Ademar de Barros, que no seu programa defendia a síntese povo-sindicato, pois considerava que o centro da organização democrática de conteúdo social e econômico era o trabalho.

O trabalho na visão dos seus integrantes deveria ser "colocado no centro da vida jurídica, econômica e política. Reconhecia, porém, na iniciativa privada a "regra" da vida econômica sujeita todavia às exceções decorrentes da necessidade da socialização, mediante indenização prévia e a luta contra os cartéis e monopólios e o poder de absorção das grandes empresas, assegurados sempre os direitos de defesa e de indenização consagrados por nossa cultura jurídica"200.

Por outro lado, o corporativismo integralista e estadonovista era proclamado tanto pelo PTB quanto pelo PPS, embora "confundível com autogestão, em termos de participação dos representantes operários nos órgãos destinados a opinar sobre a produção econômica tanto na União como nos estados e municípios"201.

Em 1949, o PPS, sob a influência do catolicismo social do Cardeal Mercia adere a uma espécie de liberalismo social cristianizado, tendo como integrantes Miguel Reale e Mário Beni, dentre outros.

Outro aspecto de destaque é que nem sempre a convivência entre o PTB e PCB fluía tranqüila. Tanto a coexistência quanto a colaboração entre eles era problemática.

No entanto, é importante frisarmos que no seio dos esquerdistas havia mais convergências não só nas coalizões (Frente Parlamentar Nacionalista, Aliança Socialista Trabalhista, Frente do Recife, entre outras, quanto nos seus dois maiores grupos de pressão: a Confederação Geral dos Trabalhadores (CGT) e a União Nacional dos Estudantes (UNE).

${ }^{201}$ Partido Popular Sindicalista (Manifesto, programa, estatutos) SP: s. e. s/d. Apud. CHACON, op. cit. p. 183. 
Enquanto isso o lacerdismo "incendiava" a classe média temerosa da proximidade entre o PCB e o PTB, ao mesmo tempo que, os grandes partidos como a UDN e grande parte do PSD buscam nos quartéis o “apoio" à Ordem. O cenário para o golpe de 1964 está se formando. . .

E no Acre, quem era quem na dança dos partidos, das siglas? Que balanço dessa época fazem os militantes?

Com a palavra, a velha guarda dos militantes políticos do Acre. 
3.2 - A voz do passado - os militantes acreanos

Naquela época havia muita perseguição. . .

Ana Carneiro Paes (D. Inglesinha)

Nesta parte da tese, a nossa perspectiva é apresentar as imagens que os militantes, mulheres e homens, tinham da política, dos políticos e dos partidos políticos existentes no Acre nos anos 50 e início da década de 1960, que marcam a tramitação do processo de elevação do Acre a Estado.

Refazer seus caminhos, acompanhar suas polêmicas, perceber a essência dos seus discursos, suas representações do vivido num cruzamento do tempo individual com o tempo coletivo, possibilitaram-nos aprender e apreender com a "escuta do outro".

A partir das experiências narradas, o "barril de pólvora" que era a política no antigo Território se ressaltava no caráter onisciente e onipresente que o Estado possuía. Desafiar o permitido, fazer leituras dissonantes das estabelecidas implicavam ter que "sair de cena" para sobreviver.

Os anos 50 foi de muita política aqui no Acre. O PTB foi criado por Getúlio. Quando começou a política, o PTB foi fundado aqui, mas o Guiomard não queria adversário, queria ser só. Aliás a gente gostava muito dele. Então eu, o meu marido [Chico Paes] o Raimundo Melo, o pai do Flaviano [Flaviano Melo, ex-prefeito e ex-governador do Acre] a mulher do Euler Braga, Goldovasse Pereira dos Santos, Idelmar Pereira Lima, José Augusto, nós fundamos o PTB. Sabe onde a sede era? Era debaixo dos benjamins que tinha lá naquela praça, naquela que fica lá perto do BANACRE, onde tinha aquelas palmeiras, tinha muita palmeira lá. Então a nossa sede era ali debaixo das palmeiras. A ata era carregada num saco de estilingue, desse que se defumam couro vegetal. Então a nossa ata era carregada ali dentro. Então, oito e meia, nove horas, nove e meia, quando tudo ficava quieto. Naquela época não tinha esse trânsito de carro que tem agora. A gente se sentava ali e fazia a roda. Lia o que era prá lê, escrevia o que era para escrever, assinava o que tinha que assinar. A perseguição era 
muito grande. Eu sempre fui PTB. Eu sou pela alma. Eu ainda hoje sou Getúlio $^{202}$.

Ana Carneiro Paes, conhecida popularmente como D. Inglesinha, por ter a pele muito branca, participante ativa da vida política e social de Rio Branco, ao revisitar o "mundo da política acreana", nos anos 50, representa-o como a época da perseguição e ao mesmo tempo enfatiza que a construção da identidade política dela e das outras mulheres e homens que integravam o PTB foi tecida na luta, na perseguição. A prática de vigiar e punir é expressa como estratégia de dominação dos que constituíam o poder político institucionalizado. A docilidade de mentes e corpos era a meta a ser conseguida. A sociedade tinha que ser integradora. Sem conflitos, sem contradições. Nem que fosse à “mão de ferro".

Quando foi criado, o PTB tinha muita mulher. Não era só eu. Tinha a esposa do Coronel Oscar Passos, a D. Ilda, tia do Flaviano. Tinha muitas senhoras aqui da cidade. Tinha a Lili do Zé Rui, dona Amélia, a mãe dela. Tudo era daqui. E começou assim debaixo daquelas palmeiras, naquela praça, sem sede, depois passou a ter sede própria. Aí começou um movimento e foi mesmo criado o Partido, organizado e registrado, aí eles não puderam fazer mais nada. O meu marido, o Francisco José Paes [chico Paes ou Zé Português] foi o primeiro presidente do diretório do $\mathrm{PTB}^{203}$.

E considerando que a memória faz e refaz o vivido, a partir do que é significante, nesse processo nossa depoente incorpora autocrítica ou a crítica a indivíduos, instituições, idéias, comportamentos, crenças, posicionamentos. . . Há, no entanto. no discurso de D. Inglesinha um sentimento saudosista. Não se faz mais política como antigamente. . .

Naquele tempo o povo gostava de comício. Juntava muita gente. Eu deixei de ir, mas dizem que o povo não vai mais. Naquele tempo quando a gente anunciava que tinha um comício lá no Quinze. Naquele tempo. Naquela época eu morava perto do Atlético, no Quinze, lá no Rabo da Besta. A gente saída anunciando e vinha gente de tudo que é lado ${ }^{204}$.

\footnotetext{
${ }^{202}$ PAES, Ana Carneiro (D. Inglesinha): depoimento. [19 de abril de 1996]. Entrevistadora: Maria José Bezerra. Rio Branco.

${ }^{203}$ Ibid.

${ }^{204}$ Ibid.
} 
Por sua vez, como assinala Michel Foucault, o poder não se ocupa, se disputa e nesta disputa perde-se ou ganha-se, formalmente, as forças políticas que "fizeram” o Estado não receberam o referendum popular para governá-lo, no que se pese neste momento a aliança nacional PSD - PTB, pois Guiomard Santos candidatou-se para governador e senador, mas ganhou apenas para senador. E José Augusto candidatou-se para governador e deputado federal, ganhou as duas, considerando-se ainda que obteve mais votos para o governo do Estado do que Guiomard Santos para o Senado.

E, ainda, Marilena Chauí nos chama à atenção, na obra “Conformismo e Resistência Aspectos da Cultura Popular", com propriedade para o fato de que não há uma relação unilateral de dominação das elites em relação às camadas populares, já que estas últimas se conformam resistindo e resistem se conformando.

As camadas populares do Acre não se constituíam uma massa amorfa manipulada ao bel-prazer das elites do PSD. O poder não deve ser visto como propriedade, mas como estratégia que comporta manobras, táticas, técnicas, disposições e funcionamentos... Há múltiplas redes de poder.

Em 62, o Guiomard se candidatou para governador e Abrahim Isper foi o vice dele. O Abrahim, o marido da D. Alegria. Era um grande comerciante, mas o povo não gostava dele. Pelo PTB, se candidatou o Zé Augusto. Então nós fizemos uma campanha bonita. O Zé Augusto, era lá do Juruá, de Tarauacá, Feijó, não sei bem. Ele estudou aqui, depois foi pro Rio, formou-se de professor. Ele se candidatou para governo e deputado federal. Queria servir a luta do povo do Acre. Ganhou as duas. Nós começamos a dizer que se o Guiomard ganhasse quem iria governar era o Abrahim. Sabe como é política, começaram a inventar um monte de coisa. . . Quando o Zé Augusto ganhou veio aqui em casa ouvir eu, meu marido, o Armando marido da Acirema, aí nós aconselhamos ele a assumir como governador e o Mário Maia como deputado federal. Depois botaram ele prá fora[. . . $]^{205}$.

No entanto, se por um lado a esmagadora vitória eleitoral de José Augusto, representava uma demonstração de força popular, do entusiasmo de colocar nos destinos do

${ }^{205}$ Ibid. 
recém-criado Estado um nativo da região, frente ao acreanismo que sempre esteve subjacente ao movimento autonomista, por outro lado, a postura esquerdista e democrática do seu governo não foi suficiente para garantir a sua permanência no poder pós-64, na medida que a deposição de João Goulart se constituiu num “golpe mortal” na vertente ideológica nacionalpopular. "Diziam que ele trouxe gente pra roubar. Que o Zé Augusto estava fazendo maracutaia. Era os deputados todo dia gritando na Assembléia que o Zé Augusto, defendendo, é porque roubava também. Aí botaram ele pra fora"206.

Lembrar o mundo da política para D. Inglesinha foi mais do que rememorar. A sua percepção dos efeitos políticos do golpe de 64 e a conseqüente deposição do governador José Augusto são apresentadas de forma questionadora, irônica, ressuscitando detalhes de forma crítica e com deboche.

E veio um comandante, um coronel do Exército prá assumir o governo. Sabe como é? Acreano é bicho covarde, fraco e frouxo. . Esse que assumiu, o Cerqueira chegou na Assembléia de short e sandália havaiana. Saiu da piscina e foi lá na Assembléia. Tava com a porta fechada, ele empurrou a porta e entrou. Eu quando lembro acho graça. Ele botou porta a dentro e entrou e disse o governador sou eu. Vocês tem que me aclamar governador aqui e agora. Vão fazer a ata. Ninguém discordou dele, quem tinha coragem. Todo mundo ficou com medo. ${ }^{207}$

Ao fazer sua releitura do passado, a depoente nos mostra o mundo dicotômico da política representado por direita (PSD) e esquerda (PTB), bem e mal, segundo o discurso conservador.

Ambas as forças políticas se alternavam no poder, embora o PSD possuísse uma capacidade maior de penetração junto às camadas populares devido à prática clientelista que adotava e às articulações que estabelecia com as lideranças políticas locais, além do fato de Guiomard Santos possuir uma inegável habilidade de seduzir, persuadir pelo discurso. "Nos 
anos 50 se fazia muita política. A política estava centrada nos dois pólos, dois partidos. O PTB, cuja liderança era Oscar Passos, e o PSD, chefiado por Guiomard Santos. E tinha outros partidos com duração efêmera, tinha outros partidos. A UDN, mas esta não vigou muito aqui $^{, 208}$.

Ao passo que para o ex-governador do Acre-Estado pós 64, Joaquim Falcão de Macedo, uma das lideranças udenistas mais expressivas no Acre, tendo sido, também, prefeito do município de Brasiléia e um dos fundadores da UDN naquela cidade, Guiomard Santos notabilizou-se devido às realizações de sua administração como governador, porém, nas entrelinhas de sua narrativa, está presente o anti-getulismo, que caracterizou a teoria e a prática política dos udenistas.

O Guiomard era. . . Ele se envolveu com a vida do Acre. Foi um dos políticos mais hábeis que já conheci, com quem convivi não conversava com dois partidos ao mesmo tempo. Ficava enrolando, mas nunca ia para o rumo que você queria. Foi o nome mais expressivo que o PSD teve no Acre. Até hoje não teve ninguém que chegasse perto dele. Foi o único governador naquela época [década de 1940] que passou quatro anos no governo. Ele tinha muito prestígio com o Presidente Dutra [. . .] Eu não vejo o crescimento do Guiomard Santos e do Oscar Passos como fortalecimento das Forças Armadas no Acre. Eles cresceram em função da conjuntura regional, nacional. O Guiomard Santos, general reformado na época que se tornou deputado federal, criou uma liderança no Estado. $\mathrm{O}$ $\mathrm{PTB}$, na época, tinha necessidade de um elemento que pudesse falar de igual para igual com ele e foi buscar esse Oscar Passos, que também foi governador. O primeiro militar que foi governador aqui no Acre, em 1942 e não passou nem um ano no governo. Ele não tinha essa liderança toda. Não tinha passado político no Acre. ${ }^{209}$

A reflexão que Joaquim Macedo faz da política da década de 50 até o início dos anos 60, centrada nas experiências políticas de Guiomard Santos e Oscar Passos, não demarca as fronteiras que existiam entre os conteúdos filosóficos e a composição social dos pessedistas e

\footnotetext{
${ }^{208}$ Ibid.

${ }^{209}$ MACEDO, Joaquim Falcão: depimento [25 de abril de 1996]. Entrevistadora: Maria José Bezerra. Rio Branco.
} 
petebistas acreanos. No seu silêncio a esse respeito, ele fala de um lugar marcadamente social e partidário.

O Guiomard era diferente, partiu de uma vivência, mas em função dele. Não havia grande diferença na política deles, dizem até que eles conversavam muito lá em Brasília prá fazer a política aqui sem perder áreas. $\mathrm{E}$ eu acredito que foi isso mesmo. As origens eram as mesmas. $\mathrm{O}$ Guiomard Santos veio prá cá depois da ditadura de Vargas. Aliás na época de Vargas vieram muitos interventores que passavam pouco tempo. E só quem dizia algumas verdades era a UDN, a partir de 1958, nos comícios, antes ninguém falava esses temas nos comícios. Ninguém criticava Vargas aqui não, ele era um mito e tinha muita força coercitiva a partir do Estado Novo. Ele usava a força contra qualquer tipo de oposição. Os dois [Guiomard e Passos] era a mesma coisa, ambos liberais, depois é que o Passos foi evoluindo para o nacionalismo[... $]^{210}$.

Por outro lado, Geraldo Gurgel de Mesquita, um dos fundadores do Partido Comunista no Acre, depois integrante do PSD, ex-governador do Acre na década de 1970 e atualmente "Presidente de Honra" do Partido Socialista Brasileiro, destaca em sua narrativa os confrontos, alianças, manobras e táticas destes "por trás das cortinas" para dividirem o poder entre si e inviabilizar o crescimento de outras facções partidárias, embora isso não seja dito de forma explícita. Está no "silêncio".

Com o tempo esses partidos foram desaparecendo. Só persistiram os que tinham base. Era praticamente o bipartidarismo o que se praticava no Acre. Houve muita inimizade por causa de política. Não eram apenas adversários, eram inimigos. Tanto é que quando viram o Guiomard e o Oscar Passos sentados numa mesa no Clube Rio Branco para um debate sobre a criação do Estado, muitos se admiraram deles se falarem, de se cumprimentarem. Os dois estavam lá como homens civilizados, porque eles nunca foram inimigos ${ }^{211}$.

Outro aspecto destacado na narrativa de Geraldo Mesquita era o papel central que o Estado e seus representantes exerciam sobre a sociedade acreana, na medida que este se constituía no pólo dinamizador não apenas da vida política, mas também social, econômica e

\footnotetext{
${ }^{210}$ Ibid.

${ }^{211}$ MESQUITA, Geraldo Gurgel: depoimento. [16 de maio de 1996]. Entrevistadora: Maria José Bezerra. Rio Branco.
} 
cultural. O grau de dependência e os conflitos não se limitavam apenas à esfera do poder político institucionalizado, mas interferiam no cotidiano das pessoas, no modo de existência.

Naquela época de certo modo se dependia da casa grande, do Palácio Rio Branco para tudo, até para internar uma pessoa, buscar uma pessoa no Aeroporto Velho, pois o avião pousava distante e só quem tinha veículo era o Território. . . A sociedade não era sujeito do Estado, mas era dependente do governo, dos seus atos. Também havia inimizade. Quem era funcionário público tinha medo de ser transferido, demitido. Havia muitos comerciantes e seringalistas que davam suporte para o Guiomard, suporte político e financeiro na época das eleições. Não entregavam para o Guiomard, mas para um encarregado de fazer as campanhas, as viagens, os comícios, a propaganda. Eu era do partido do Guiomard, porém antes de nascer o meu primeiro filho em 43 , até um pouco depois, no fim da guerra em 1946, por aí, no governo Dutra, eu participei aqui no Acre da implantação de um núcleo do partido comunista do Brasil, não é esse atual. Era do Brasil que depois passou a ser brasileiro e depois houve o racha e ficou brasileiro e do Brasil. Digamos assim o partido de Prestes, tinha aquele baiano, o Jorge Amado, aquele guerrilheiro o Lamarca, ou quase guerrilheiro. O Mariguela ${ }^{212}$.

Importante também considerarmos que o PCB, embora tivesse seus simpatizantes e

militantes, estes raramente davam livre curso às suas idéias devido à prática mais comum dos

comunistas acreanos de terem sido abrigados no "guarda-chuva" do PTB, além de carecerem

de fundamentação teórica marxista -, quando muito conheciam as palavras de ordem, de

crítica ao capitalismo.

Foi um período pequeno, mas eu pertencia ao PCB aqui no Acre. Mas era sem orientação filosófica, sem sequer ter visto um retrato de Marx ou de Lênin. Só ouvia comício de comunistas quando ia ao Ceará, lá eu podia falar. Havia tanta coisa ruim no Brasil que a gente só tinha dois caminhos, quando era jovem e pensava no Brasil, ou era integralista ou comunista, o que não podia ser era daquela raça que governava o Brasil nesse período. Não vou incluir aí nem Juscelino, nem João Goulart, ou ainda alguns homens da revolução [64], como Geisel ou Castelo Branco. O Castelo Branco era um homem altamente qualificado. Sem embasamento filosófico e eu não podia fazer curso de sociologia ou socialismo, não podia ter um preparo, aí fiz uma auto-análise da posição tomada e achei que estava sendo inconseqüente. Eu não podia militar, entrar numa luta braba, porque não tinha preparo para aquilo. Eu não podia continuar daquela forma e também não podia adquirir os conhecimentos necessários, aí me desliguei.

212 Ibid. 
Prosseguindo em suas narrativas, Geraldo Mesquita enfatiza sua trajetória partidária

destacando que:

Mas ficou muito tempo aí [a informação de que tinha sido comunista]. Isso nunca me atrapalhou nas minhas campanhas. O Fleming orquestrava essa coisa que ele soube. Passei muito tempo sem partido. Grande parte do governo do Guiomard Santos eu passei fora 47, 48, 49 e aí me filiei ao PSP, um período aí, era o partido do Admar de Barros, depois me filiei ao PSD, passando por seus sucessores até a Arena, o próprio PDS, de onde me desliguei em 1982, por discordar de uma convenção partidária, comandada pelo Senador Jorge Kalume, lá no Ginásio Coberto, quando eu defendia uma outra candidatura, que não fosse a dele. Aí pensavam: você já foi governador, o Dantas já foi. Briguei e sai. Hoje eu faço parte do PSB, do Partido Socialista Brasileiro $^{213}$.

Omar Sabino de Paula, integrante das fileiras do PSD e militante do Movimento Autonomista, tendo sido inclusive Redator-Chefe do jornal "O Estado" e ativo membro do

Comitê Pró-Autonomia, localizado em Rio Branco, ao fazer um balanço se valeu a pena o

Acre ter se tornado Estado, diz o seguinte:

[. . . ] na primeira Constituição do Estado nós já encontramos alguns pontos positivos da elevação do Acre a Estado. Primeiro é a própria organização, a própria presença dos poderes que não existiam no Acre. $\mathrm{O}$ judiciário no sentido de sua cúpula. $\mathrm{O}$ tribunal e o legislativo num sentido muito amplo, prá começar do legislativo estadual para o legislativo municipal. Uma democratização maior. O direito de sufragar, de votar, de eleger os seus representantes. Do outro como conseqüência também de Constituição a criação de novos municípios aqui no Acre. Tudo isto foi muito bom para o povo [. . .] a criação de Universidade, a previsão de necessidade de uma universidade no Acre, a criação da Policia Militar do Estado do Acre, a criação do Banco do Estado do Acre [. . .] A criação do Estado do Acre trouxe muitos benefícios. E a universidade era importante porque iria qualificar recursos humanos para atender as demandas do Estado, do serviço público. [. . .] Diziam na época que o Acre não possuía condições financeiras para ser Estado, para se manter, para manter a máquina administrativa, enfim a democracia ganhou com a elevação do Acre a Estado. Território era um regime unitário, a dependência da União era direta e como as comunicações eram difíceis, nós nem sabíamos quanto tempo ia ficar um governador. Tudo era decidido fora. Ninguém resolvia nada dos problemas do Acre. Com o Estado podemos debater os nossos problemas e encontrar soluções[... $]^{214}$.

${ }^{213}$ Ibid.

${ }^{214}$ PAULA, Omar Sabino: depoimento. [23 de maio de 1996] Entrevistadora: Maria José Bezerra. Rio Branco. 
Nessa perspectiva, segundo a sua concepção, transformar-se em Estado era a alternativa que existia para que a região alcançasse o almejado progresso, inclusive o projeto de criação de uma universidade estava imbricado ao processo de transitação do Acre de Território a Estado, na medida que se tornava necessário qualificar recursos humanos de nível superior para gerir os destinos da máquina administrativa estatal.

Não havia outra saída, senão o Acre ser Estado. Se não fosse naquela época fatalmente seria com a Constituição de 1988. Nós tínhamos confiança nas possibilidades do Acre, a mocidade acreditava que com o Estado o ensino iria melhorar. Viria a Universidade e aí desde Juscilino Kubstchek, mineiro amigo do Guiomard Santos, com aquela euforia que existia o Acre teria uma perspectiva. Viria as estradas. Com a inauguração da rodovia ligando Brasília ao Acre, inaugurada por JK, no governo do Fontenelle. Isto já era uma garantia de que o progresso chegaria ao Acre. Era o ponto inicial para o desenvolvimento. Afinal, passamos a ser responsáveis pelo nosso destino. A nossa luta deu continuidadade a daqueles que conquistaram o Acre, que abriram as clareiras, incorporando o Acre ao Brasil. Também cresceu o sentimento de amor ao Acre. Passamos a integrar a federação brasileira. Nasceu o orgulho de ser acreano. Passamos a ter orgulho de nossa cultura[... $]^{215}$.

Dessa forma, podemos inferir que, subjacente à luta pró-autonomia do Acre, estava presente a perspectiva do "Acre para os acreanos". O acreanismo, enquanto afirmação da cultura e da gente acreana, concretiza-se com a eleição do jovem juruaense José Augusto de Araújo.

Nos debates, ele [Guiomard] sempre admitia que com o Estado o primeiro governador deveria ser um acreano. $O$ ideal dele era que houvesse uma coligação dos partidos para eleger um candidato da terra. Ele admitia concorrer as eleições, para o governo do Estado, mas achava que quem deveria assumir era um filho da terra. Nos contatos que tivemos, eu e o Guiomard com a cúpula do PTB, o Rui Lino, o Aníbal Miranda, o próprio general Passos, eles diziam que já tinham um candidato para o governo. Era o José Augusto[....] $]^{216}$.

${ }^{215}$ Ibid.

${ }^{216}$ Ibid. 
Ressalta também que as organizações pró-autonomistas foram decisivas para articular as forças políticas locais e mobilizar a população para a causa autonomista, em especial o Comitê Pró-Autonomia radicado em Rio Branco, na época Capital do Território do Acre.

Eu, a partir de 1950, é que me engajei na luta autonomista. Na primeira fase do projeto e foi quando o movimento autonomista tomou corpo pela liderança do então deputado federal, Guiomard Santos. O projeto teve uma tramitação muito longa de 1957 a 1962, e enquanto nós acompanhávamos através do Jornal "O Estado", cujo diretor era o próprio Guiomard e eu o redator chefe, nós registrávamos e divulgávamos todos os fatos sobre a questão. Tudo o que o comitê Pró-autonomia do Acre produzia. Também esta fundado por volta de 1957. O comitê foi decisivo para a autonomia do Acre, além de outras organizações que existiam, como a Legião Autonomista fundada em 1934. O Presidente do Comitê era o prof. Geraldo Mesquita e tinha também um grupo de jovens como o Darci Fontenelle, o Edson Martins, eu [Omar Sabino], o prof. Aldenor, o Diniz Aguiar, o Raimundo Gomes de Oliveira e muitos outros. Na Segunda fase eu fui Presidente da Comissão Provisória Executiva e elegemos o prof. Mesquita para compor a Comissão definitiva, como Presidente e eu fiquei como Secretário ${ }^{217}$.

Enfatiza ainda o depoente o papel dos meios de comunicação de massa como essenciais à mobilização popular, mormente considerando que as comunicações internas por via terrestre eram deficitárias, restando apenas o avião ou as embarcações.

O jornal, o rádio e o telégrafo se constituíram nas vias de acesso às populações e lideranças políticas de todo o Território do Acre e deste com a capital da República.

O Comitê prestava esclarecimento ao povo e também rebatia os ataques. Através de correspondência mantínhamos contato com todos os senadores e deputados e as vezes diretamente com o deputado Oscar Passos e outros líderes da oposição tentando demonstrar a possibilidade do Acre ser Estado. Em 1958, governava o Território, o então Coronel Fontenelle de Castro, que já tinha comandado a Polícia Militar e cujo secretário geral, o Jorge Lavocat deram muito apoio ao Comitê. Como diretor de imprensa e rádio difusão eu era também diretor do jornal "O Acre" órgão oficial do governo do Território e dirigia ainda a Rádio Difusora Acreana. Na época a gente instalou a Rádio Difusora de Cruzeiro do Sul. Tudo isto nos ajudava a mobilizar o povo ${ }^{218}$.

${ }^{217}$ Ibid.

${ }^{218}$ Ibid. 
Mais adiante, ao avaliar os fatores que contribuíram para a aprovação do projeto de elevação do Acre a Estado, destaca o papel de articulador de Guiomard Santos junto ao PSD mineiro e nacional e a credibilidade e respeito que ele gozava devido à administração como governador delegado da União nos Territórios de Ponta-Porã e Acre.

Mas a maior repercussão ao projeto deve-se ao prestígio parlamentar do Guiomard. Homem vivido, ligado ao PSD mineiro, duas vezes governador do Território [Ponta Porã e Acre] que buscou sensibilizar seus colegas para a causa do Acre. $O$ trabalho direto e pessoal dele foi muito importante. O apoio do PSD nacional contou muito e naquela época o PSD contava com o apoio do Presidente da República, com o apoio de Tancredo Neves. O Tancredo Neves ainda influiu mais adiante, naquela época de regime parlamentar. Quando foi assinada a lei ele era Primeiro Ministro e João Goulart era Presidente. Além de contar com o apoio do PSD mineiro, ele tinha uma capacidade de convencimento muito grande. Era um homem de muita cultura. Tudo isto contribuiu ${ }^{219}$.

Importante considerar que as memórias dos velhos militantes dos partidos políticos nos permitiram conhecer "quem era quem" na política acreana, a partir do que foi significativo para cada um. Os recortes que fizeram do vivido, ouvido ou imaginado se constituem representações racionalmente inventadas eivadas de nostalgia, sonho, crítica, autocrítica, saudade. . .

Eu nasci no Seringal Nova Olinda, aqui na margem do rio Acre. Fiquei no seringal até praticamente 1948. Nessa época eu vim para Rio Branco. Aí entrei no serviço público em 1948. Meus pais vieram do Maranhão e do Ceará e foram para o seringal Nova Olinda. Chegaram lá no seringal por volta de 1912. Eu sempre lia muito. Lá no seringal de trinta em trinta dias chegava muito jornal. A minha diversão era ler. E foi aí que conheci os maiores jornalistas da Amazônia, inclusive um que era diretor da Folha do Norte, eu através dele peguei amor a política. [. . .] a partir de 1930 é que começa a luta partidária aqui no Acre. $O$ partido daqui era a Legião Autonomista, era o mais importante e a chapa popular era o partido do judiciário. Em 45 foi quando Getúlio criou tanto o PSD quanto o PTB. Tinha ainda a UDN, que era de oposição e eu me filiei a este partido. Eu gosto de ser oposição, isto já me deu muita dor de cabeça, mas eu gosto de ser oposição ${ }^{220}$.

${ }^{219}$ Ibid.

${ }^{220}$ JARDIM, Foch: depoimento [23 de setembro de 1996]. Entrevistadora: Maria José Bezerra. Rio Branco. 
Foch Jardim, udenista ferrenho, oposicionista por convicção e vocação, tendo sido inclusive cassado após 64, destacou-se no cenário acreano como jornalista e sobretudo como "aquele que não tinha papas na língua".

A crítica cortante aos poderosos da época lhe trouxe vários dissabores, porém não arrefeceu seu caráter aguerrido.

Em 1953, nós fundamos o Grupo Renovação. Era muito heterogêneo. Era um grupo de intelectuais. Fazia parte o Geraldo Mesquita, Jerônimo Ferrante, Goldovasse Santos, eu [Foch Jardim] tinha também o Tarzan, Ildemar Pereira Lima. A primeira publicação saiu em 1953. Era um jornal semanal e para produzi-lo era uma luta. Tudo artesanal e aí com a saída de vários companheiros pois o Goldovasse Santos foi para o governo, o Ferrante pegou um cartório, todo mundo foi fazer outra coisa, aí eu o transformei no Liberal e assim ficou até $1974^{221}$.

Lembrar o mundo da política acreana significou trabalhar com acontecimentos de suas próprias vidas, lidar com imagens de pessoas, lugares, fatos que estavam adormecidos no mais profundo da alma, permitindo-nos ter acesso a nuances dos embates presentes na invenção do Acre Estado.

A UDN aqui era uma espécie de fiel da balança, já que os grandes partidos eram o PSD e o PTB. Eu cheguei a presidir a UDN e a gente formava o bloco de oposição ao Guiomard, aliás não era ao Guiomard, era ao Getúlio. Desse pessoal não resta mais ninguém - morreram, foram embora, só resta eu. Era tudo de fora. [. . .] Em 50, começou um movimento político no Acre, e aí vieram as administrações de Amílcar de Menezes, depois o João Kubitchek Figueredo, que também fez um bom governo. Muito pacato. Em 1952 articularam uma aliança entre o PSD e o PTB para escolher o Dr. Abel Pinheiro, que veio lá do Juruá. Como médico excelente, mas como administrador era muito ruim. Como eu fiz uma matéria sobre o governo do D. Abel que não gostaram, me chamaram lá no Palácio, abriram Comissão de Inquérito, passei a ser perseguido, navalhado, tive o jornal quebrado, apreendido ${ }^{222}$.

${ }^{221}$ Ibid.

${ }^{222}$ Ibid. 
Experienciar e recordar fragmentos do mundo político acreano e de suas vidas inseridas nesse contexto demonstrou a relação dialética existente entre ação e representação, numa compreensão do tempo social em que a memória recolheu da política da época o conhecimento do passado, com o olhar do presente.

Era difícil fazer oposição naquela época. [. . .] O Renovação funcionava lá no $2^{\circ}$ Distrito, no porão da casa de Domingos Santos, ali junto do Mercado Velho. No liberal, a gente combatia o projeto do Guiomard. E até dizer que o projeto aprovado não foi o do Guiomard. O projeto dele sofreu alterações, os substitutivos. Aliás, o substitutivo que foi aprovado teve o parecer de um udenista, o Jaime Araújo, lá do Amazonas. Naquela época era difícil fazer um jornal. O jornal era só local não havia condições de enviar para outros lugares. $O$ forte do liberal era a parte política, eram quatro páginas, mas tinha também a parte de esporte e social. O udenista social surgiu no meu jornal, eram João Astro e Cláudio Ribeiro. Como o jornal combatia o governo local, a gente botava vendedor que saía vendendo nas ruas, nas casas. Você tem que levar em conta que naquela época 500 jornais, era essa a tiragem, era muita coisa[. . . $]^{223}$.

O passado é visto como um tempo de luta, de oposição, de repressão. Mais do que reviver, recontar o vivido, foi refazer o vivido reelaborando as lembranças, avaliando e questionando a ordem política estabelecida.

Mesmo com toda a repressão a gente fazia oposição. Eu procurava atacar os dois coronéis. Por exemplo, teve uma matéria, que eu dei o título de "Feudo dos Coronéis", aí um chegava aos dois coronéis [Guiomard Santos e Oscar Passos]. . . Foi um título que quase me levou a cassação. Aí eu também fiz a campanha do Jânio Quadros, eu era Janista roxo e nós ganhamos no Acre. [. . .] Nós apoiamos o Juarez Távora. Cheguei a ser cotado para o governo do Território, mas eu não tinha estrutura para ser governador naquela época, citei o Romildo, mas quem ganhou foi o Altino Machado e ele me apoiou. Depois cheguei a ser diretor da imprensa oficial, mas um dia chegou uma ordem, um decreto nomeando Aloísio Queiroz, Prefeito de Cruzeiro do Sul, aí eu me revoltei, ele era o meu maior inimigo. Passei a publicação, o material, para outro e entreguei o cargo ao governo, depois fiz uma matéria prá valer de quatro páginas contra o Aluísio. Quando veio a "revolução", a primeira coisa que ele fez foi telefonar para o Exército e pedir minha cassação. Não me cassaram, mas tiraram do serviço público, fui posto em disponibilidade. . ${ }^{224}$

${ }^{223}$ Ibid.

${ }^{224}$ Ibid. 
Adentrar as memórias desses velhos militantes é percorrer um território desconhecido para as novas gerações e até para a produção historiográfica acreana, na medida que tais temas ainda não tinham sido abordados. Revisitar os conflitos entre as forças políticas do Acre é também perceber que entre memória e história não há oposição, mas alteridade, em que a construção das identidades políticas e a representação do passado se aproximam. "Logo após 1979, depois da anistia, eu fui aposentado, adiantamos o serviço e me aposentei. Durante o período em que fiquei em disponibilidade mantiveram o meu salário. Depois dessa época passei a escrever apenas artigos culturais" ${ }^{\prime 225}$.

A memória de Guiomard Santos, mito da política acreana, ainda cultuada por representantes das forças políticas atuais do Acre, inclusive de esquerda, é demolida na narrativa do oposicionista Foch Jardim.

O Guiomard foi integralista. O integralismo nos anos 30 foi muito forte aqui. Não, aqui os integralistas não foram perseguidos. Muitos poderosos eram integralistas. Que eu saiba os integralistas aqui eram o Mário de Oliveira, o Miguel Ferrante. As principais autoridades eram integralistas. Nos anos 30, tinha até seringalista que era integralista $[\ldots]^{226}$.

O fascínio que as idéias comunistas exerciam sobre os jovens também se fez sentir no Acre. No entanto, frente ao caráter repressivo do Estado brasileiro e acreano, estes, na sua maioria, ou ficavam "na moita" ou abrigavam-se no PTB.

Comunistas confessos é difícil de saber se havia. Mas existiam dois rapazes que vieram para cá. Eles não eram ideólogos. Eram radicais de rua. $\mathrm{O}$ ideólogo era o Pacheco, um rapaz que era professor no Ginásio Acreano, Toiro Café. Esse sim era ideólogo do Partido Comunista. O Mesquita, o Luís Cavalcanti, o Humberto Soares. Existiam mais intelectuais que tinham afinidade com o comunismo, mas não eram comunistas. $\mathrm{O}$ partido foi fundado aqui. Eram da Aliança Nacional Libertadora. Eles não tinham lugar certo para se reunir. Já os integralistas se reuniam toda semana na Tentamen. O Mário de Oliveira chegou a presidir o Partido Integralista. Já dos comunistas a gente sabe pouco. O João Borborema foi comunista, mas

${ }^{225}$ Ibid.

${ }^{226}$ Ibid. 
passou pouco tempo, o irmão dele é que era comunista, foi até para Cuba. Tinha o João Barbeiro que era meu barbeiro e para eu entrar na casa dele tinha que saudar Carlos Prestes, o cavaleiro dos comunistas. Ele tinha uma raiva danada de mim porque eu combatia o Getúlio. Ele era um sujeito inofensivo, ele não tinha atuação. Ele só conversava na barbearia dele, com quem ia lá. Não era tipo de estruturar o partido ${ }^{227}$.

Wildy Viana, natural de Brasiléia, um dos fundadores do PTB e pai do atual governador petista Jorge Viana, na sua narrativa também apresenta os anos 50 e início da década de 1960 como o tempo da perseguição, da repressão. A fala contrária à ordem partidária estabelecida tinha que ser calada. . .

Nasci em Brasiléia e fiquei lá até os 23 anos. Na época tinha muita perseguição política e então meu pai [Virgílio Viana das Neves] era transferido. Quando vim para Rio Branco o governador aqui era o João Kubstichek. Lá em Brasiléia, nas horas vagas eu aprendi telegrafia. Aí quando cheguei aqui fiz um teste na Rádio do governo e fui aprovado para o serviço público. Na primeira eleição do Acre-Estado me candidatei para vereador. Eu era fundador do PTB, eu e meu pai lá em Brasiléia e a minha candidatura aqui foi rejeitada. Na época quem presidia o PTB era o José Rui da Silveira Lino. Era o dono do PTB, o Raimundo Melo, o Aníbal Miranda e o Oscar Passos que governou o Acre em 1942 e que nessa época [Anos 50] era deputado federal ${ }^{228}$.

Ao olhar aquele outro tempo da política em que teve a experiência de ser rejeitado pela

agremiação partidária que estava relacionada às suas origens familiares e pessoais, Wildy

Viana evidencia como deixou de ser PTB e passou para as fileiras da UDN.

Com a rejeição eu fiquei abatido, mas na época era Presidente da UDN, seu Chiquito, e a médica Lis. Seu Chiquito era o pai do Moacir Fecury, que foi Reitor da UFAC. Seu Chiquito era um dos chefe da UDN. Aí eu me juntei ao Joaquim [Joaquim Macedo foi governador do Acre pós Golpe Militar de 1964]. Era meu cunhado e Presidente do Diretório Regional da UDN. Aí ele disse vamos fazer uma espécie de coligação com a UDN, que era contra o PSD. A gente te dar uma vaga. Eles pegaram três vagas. Um para vereador e duas para deputado estadual e aí eu entrei numa destas 3 vagas e aí bati no ombro do pessoal do $\mathrm{PTB}^{229}$.

${ }^{227}$ Ibid.

${ }^{228}$ VIANA, Wildy.: depoimento [09 de julho de 1996]. Entrevistadora: Maria José Bezerra. Rio Branco.

${ }^{229}$ Ibid. 
Não é sem motivo que as rivalidades entre as famílias mais antigas do Acre estão relacionadas ao jogo político dos anos 50 e 60 . As posições e práticas de vários dos seus integrantes constituem ressonâncias de um outro tempo da política.

Fui o $2^{\circ}$ mais votado. Quando o Aníbal Miranda foi cassado pela Câmara Municipal eu era Presidente da Câmara. Na época tinha 4 do PSD e 4 do PTB e eu sozinho da UDN, não sei porque os 8 votaram em mim e fui presidente. Depois eu renunciei a presidência da Câmara e para o meu lugar, o Kalume [Jorge Kalume] indicou o Adauto Frota. Em 1966 concorri a reeleição e me elegi deputado estadual, e depois mais duas vezes. Em 1979, concorri para deputado federal e me elegi. Em 1982 concorri novamente a deputado federal e me elegi. Em 1986, eu me senti assim incompatível com a realidade política brasileira, eu percebi que era outro tempo $^{230}$.

O repressivo território da política implicava também estabelecer fronteiras físicas, demarcar espaços, numa espécie de geografia político-partidária.

Naquela época dos anos 50, a política era muito dura. Quem não votava no candidato do governador quando terminava a eleição ia para a rua. Era o corte. Naquela época não tinha estatutário aí jogavam todos na rua. Aqui a intriga política era muito grande. Em Brasiléia nem se fala. Tinha rua que daqui prá ali era do PSD e daqui para cá era do PTB. Mas os dois [Guiomard Santos e Oscar Passos] brigavam aqui, mas lá na Câmara se falavam e até pareciam amigo depois da campanha política. ${ }^{231}$.

No universo político acreano, o PSD não reinava sozinho, como faz parecer o discurso oficial, pois, embora o primeiro estivesse relacionado às elites locais da época - grandes seringalistas e comerciantes -, o PTB gradativamente engrossou suas fileiras com militantes oriundos das camadas populares. Embora, também, alguns membros das elites locais integrassem o partido, constituíam minoria.

${ }^{230}$ Ibid.
${ }^{231}$ Ibid. 
O PTB aqui no Acre era uma grande liderança. Muitas famílias aqui em Rio Branco eram do PTB, como os Melo, os Mesquita, não era a família do Geraldo Mesquita, este era do PSD ${ }^{232}$.

O território do Acre aparece no discurso de Wildy Viana como arena dos confrontos entre PSD e PTB.

O PSD era o partido dos ricos, dos seringalistas. Era muito difícil um seringalista ser do PTB. Precisava ter coragem. O PTB, era uma espécie de PT, quando começou precisava ter muita coragem prá botar a cabeça prá fora, porque era perseguido. Não vendia borracha, não conseguia financiamento com o Banco da Amazônia. Os parentes eram perseguidos.. . O PTB tinha um pouco de elite, mas era mais funcionário $[\ldots]^{233}$.

A partir da narrativa abaixo, as desavenças presentes nas relações sociais dos integrantes do PSD, PTB e UDN são "fotografadas" em movimento pela memória. Aquele tempo era o da disputa e não difere de hoje.

A UDN era um pessoal brabo, mas eram poucos, mas brabos. Eram os que não dependiam do governo. Esses eram mais olhados pelo governo, mais odiados. Eles eram a terceira força política. Cabra que assinava ficha de filiação na UDN, assinava escondido. Não dava para brincar não. Se fosse funcionário público estava liquidado. Se tivesse um irmão, cunhado, parente, filho, irmão todos iam ser perseguidos. Todo mundo ia ser perseguido. Mesmo no Acre-Estado não mudou muito. A história continua a mesma. Ah! Fulano é muito amigo de beltrano, então está liquidado. As famílias se dividiam[... . $]^{234}$.

No vaivém dos partidos, na gangorra partidária, a UDN não conseguiu se firmar. O poder no Acre era partilhado entre pedessistas e petebistas e os dois, quando necessário, aliavam-se para combater os udenistas.

Não havia diferença entre PSD e PTB. O PSD ficou no poder quase a vida inteira fazendo as coisas que a gente sabe. O PTB quando assumiu quis se nivelar ao PSD e em 8 anos o PTB não é mais o mesmo. [. . .] A UDN

\footnotetext{
${ }^{232}$ Ibid.

${ }^{233}$ Ibid.

${ }^{234}$ Ibid.
} 
nunca teve oportunidade. Nasceu, cresceu e acabou e nunca chegou lá. Era muito radical. O Presidente Nacional, Eduardo Gomes dizia que lugar de mulher. . . No dia que ele se elegesse Presidente da República tudo que era mulher na política ía para casa. Falavam até dele porque nunca casou. A UDN foi sempre pequena. O Macedo, o Foch, Ilde Maia, Mário Maia, este último só para se eleger depois passou para o PTB. E o Rodolfo Bader, pai da Clara Bader, ele teve um tempo na UDN. O mais forte dela foi nos anos 60. A posição da UDN era de oposição. Ela era contra o roubo, a bandalheira, contra essas coisas erradas ${ }^{235}$.

O governo de Jânio Quadros, como símbolo da mudança, está bem presente no discurso de Wildy Viana. No entanto, esse sonho foi estilhaçado pela renúncia deste.

Aí o Jânio apareceu com a vassoura dizendo que ia varrer todo mundo, batemos palma. Nós queríamos um horizonte de dignidade e apareceu essa chance. O Jânio renunciou, aí tudo acabou. O governador daqui foi demitido. O Joaquim Macedo foi demitido em Brasiléia. O Osvaldo Lima, pai do Peri, demitiu o Macedo do cargo de Prefeito de Brasiléia. [. . .] Na época de transição [de Território para Estado] Rui Lino saiu para candidatar-se aí assumiu o Aníbal Miranda, aí saiu o Aníbal e entrou o Dr. Pojucan Ribeiro. Ele era professor de História ${ }^{236}$.

Por outro lado, Aníbal Miranda, ativista ferrenho do PTB, cassado após 64, rememora sua trajetória política no Acre destacando implicitamente as "estratégias" do partido que integrava para sobreviver frente ao "reinado" do PSD.

Eu vim para o Acre em 1950. Nasci em Manaus e lá estudei agronomia. Ingressei na política nos anos 50. Conheci o Rui Lino em Manaus e aí encontrei ele aqui. Ele e o Passos foram os fundadores do PTB no Acre. E eu antes de chegar aqui já era PTB. Cheguei aqui no dia da eleição 3 de outubro de 1950 e o PTB já estava ganhando as eleições. Aí eu continuei na política comendo só pelas beiradinhas e aí em 1959, é que entro mesmo. Em 60, 61, 62 eu fui ser governador quer dizer o Zé Rui era governador, na época da assinatura da lei 4.070 que elevou o Acre a categoria de Estado. Vale dizer que o projeto aprovado, não foi o mesmo apresentado pelo Guiomard. Sofreu modificações. O PTB não queria o Projeto. O Acre não tinha condições de ser Estado ${ }^{237}$.

${ }^{235}$ Ibid.

${ }^{236}$ Ibid.

${ }^{237}$ SILVA, Aníbal Miranda: depoimento [03 de julho de 1996]. Entrevistadora: Maria José Bezerra. Rio Branco. 
Revisitar o vivido, para Aníbal Miranda, mais do que reconstituir o passado, significou expressar suas convicções, crenças, sentimentos, decepções, vitórias. . Na sua condição de "peixe pequeno" na luta contra os "tubarões" da política acreana, nem sempre "levou a melhor"...

O PSD era elite, mas a UDN era mais elite ainda. A UDN era a elite intelectual. O PSD eram os comerciantes, os seringalistas. As fazendas, tudo era deles. Agora o PTB era peixe pequeno só comia pelas beiradas. Não tinha nada. E aí quando eu fui cassado [. . .] Eu fui cassado pelo Castelo Branco em 4 de julho de 1966. Eu desde o Rio, antes de chegar ao Acre já era PTB, ia aos comícios lá. Então o negócio era o seguinte: O PTB não queria o projeto, aí eles procuraram a UDN pois o Guiomard não conseguia quorum para aprovar o projeto. E a UDN era oposição a Getúlio, tinha Carlos Lacerda e aquele pessoal todo ${ }^{238}$.

Na sua fala, o mérito de Guiomard Santos como autor do projeto de elevação do Acre a Estado é relativizado, pois o projeto original sofreu várias alterações, modificando substancialmente o texto original.

Aí disseram nós vamos aprovar, mais não vai ser este projeto o que nós vamos aprovar, aí eles redigiram [. . .] O Guiomard era um bom administrador, mas era demagogo. Bom administrador é verdade. O Guiomard aqui era como um deus. Não sei quantas ruas tem o nome dele. Conjunto 1, 2, 3, 4 [Conjunto habitacionais], tudo é Guiomard Santos. Ele nem gostava disso. Era os autonomistas. O Omar Sabino, esse pessoal. O projeto foi redigido é pelos economistas da UDN, se ele não aceitasse o projeto não seria aprovado. Eu estou relatando isso aqui, que é prá ficar na história do Acre. Foi o Jaime Araújo, deputado da UDN, que ainda deve estar vivo ${ }^{239}$.

Nas suas lembranças, o território da política é um campo movediço. Aquele que chega ao poder tem que enfrentar armadilhas as mais diversas. Ser esperto é uma forma de conviver num mundo de "lobos". As articulações por trás dos bastidores, o compartilhar "segredos" muitas vezes são vitais para a sobrevivência política.

${ }^{238}$ Ibid.
${ }^{239}$ Ibid. 
Agora a minha cassação, bem quando eu fui nomeado governador, porque eu também já fui secretário do ex-Território do Acre. O Rui era governador e eu secretário, aí o Rui [José Rui] tinha que descompatibilizar do cargo de governador para poder se candidatar a deputado. O secretário dele era o Mesquita [. . .] Eu já sabia que ia ser o governador, mas, ninguém sabia, nem o Passos [Oscar Passos]. O Mesquita queria fazer o governador que fosse do PSD, mas eu assumi o governo legalmente. Tá lá na lei orgânica dos Territórios. Eu guardo esta lei escondido numa gaveta. [... .] Quando o chefe de gabinete leu a minha nomeação no diário oficial, eu assinei a posse, o José Lino, também assinou. Aliás esse livro desapareceu. .. Eles [PSD] durante o meu governo queriam me derrubar[. . .] ${ }^{240}$.

Na sua reelaboração do passado, Aníbal Miranda trabalha qualitativamente o passado e, nesse sentido, dá ênfase às perseguições sofridas e à luta para readquirir seus direitos políticos e as aposentadorias a que fazia jus.

Eu saí um tempo. Depois estavam falando de anistia e coisa e tal. O Presidente era o Figueiredo. Aí eu peguei e vim. O governador era o Macedo e o chefe da Casa Civil o Elias Mansour aí eles fizeram tudo direitinho, eu voltei a trabalhar e em 1963 me aposentei como engenheiro agrônomo. Mas eu tinha direito a ser aposentado como ex-governador. Aí falei com José Rui que levou a papelada para Brasília, falou com o Dr. Ulisses Guimarães e o pessoal dele que entendia de Direito Administrativo, aí eles mandaram para Assembléia do Acre, que em menos de três dias aprovou e aí eu fiquei ganhando como ex governador. Recebi um bocado de tempo, aí esse besta aí [Governador Orleir Cameli] não quer pagar $[\ldots]^{241}$.

Lembrar é também classificar, estabelecer juízo de valor sobre pessoas, instituições, épocas, coisas. . . O Acre Território é pensado e classificado como o espaço da repressão política.

Naquela época do Guiomard fazer política era muito difícil. O Guiomard era nazista. Era integralista. Eu conheci o Guiomard em Manaus, como tenente, ele era integralista. Era adepto das idéias de Plínio Salgado. Tinha muito integralista aqui. [. . .] Eu conheci ele lá em Manaus, com aquela farda dos integralistas, desfilando. Aliás ele nunca negou. [...] Qualquer pessoa que quisesse fazer um partido, o Guiomard falava logo, se fosse casado bota ela prá Feijó e a mulher prá Vila Plácido. Teve muito disso aqui. Na época dele ninguém podia falar. As reuniões do Partido [PTB] tinha que ser escondido[... $]^{242}$.

\footnotetext{
${ }^{240}$ Ibid.

${ }^{241}$ Ibid.

${ }^{242}$ Ibid.
} 
Percebemos durante os contatos que mantivemos que a vida do Sr. Aníbal Miranda, do ponto de vista individual e social, "parou", estagnou-se após a sua cassação. Os fatos lembrados por ele traduzem a amargura de ter sido obrigado a deixar a cena política. Está implícito no seu discurso que outros devem realizar as possibilidades que ele não teve oportunidade de concretizar.

Eu sempre gostei de política. Aprendi a fazer política com meu pai. Meu pai era do PSD. Eu nunca fui na idéia dele. Ele dizia você vai. Eu dizia eu não vou não. Eu ajudava muito ele. [.. .] Agora antes da minha cassação, eu fiz um governo aberto, democrático. Os próprios adversários políticos me tratam muito bem. Tanto é que depois fui Prefeito da Capital. O primeiro prefeito eleito de Rio Branco, depois que o Acre foi Estado e o José Augusto tinha assumido o governo do Acre. O José Augusto queria que o Meira [docente da UFAC e militante do PTB], o Meirinha, fosse o Prefeito, mas eu tinha muitos amigos no PTB, meu partido ainda hoje é o PMDB. Tem gente até que vem aqui dizer porque não me candidato novamente. Aí eu fui prefeito, ganhei na convenção do partido e ganhei do candidato do PSD, Dr. Ari Rodrigues. ${ }^{243}$

Portanto, o "tempo do Guiomard" é algo sempre recorrente na fala de Aníbal como a época da repressão, do arbítrio, da impossibilidade de exercício da democracia. Guiomard Santos marca o tempo, é o tempo, faz o tempo. O tempo deixa de ser uma categoria abstrata para representar uma vivência concreta. As narrativas de nossos depoentes traduzem o olhar de cada um no tempo e através do tempo.

Eu fui cassado depois de 64 por causa do Guiomard. Muita perseguição política. Ele e o Cerqueira foram lá com o Ministro Mendes Sá e disseram "lá no Acre tem 2 que precisam ser cassados: o Aníbal Miranda e o José Augusto". O José Augusto já tinha sido cassado. Faltava eu. Aí eu fui cassado. Eu tinha um amigo lá do PSD que me contou. O PSD era um partido muito forte. E o Guiomard tinha poder. Quando ele chegou aqui prá ser governador pediu a chave do diretório do PSD e trancou a sala, que deixou de funcionar. Não fez mais reunião de partido e trabalhou como se fosse mesmo um ditador. Foi um grande realizador, tinha seus ideais, mas era integralista. ${ }^{244}$

243 ibid.

244 Ibid. 
Assim, nesse contexto marcadamente antidemocrático, ter a ousadia de apresentar-se como comunista implicava ser marginalizado, perder os direitos políticos. No entanto, resistir mesmo na "escuridão" denota a capacidade de contestação das camadas populares à Ordem instituída, na medida que a maioria dos que se denominavam comunistas era proveniente dos setores sociais subalternos.

E os comunistas daqui não tinham o partido bem estruturado, mas existiam os comunistas históricos, o Abel Melo, o pai do Raimundo Melo e o Barbeiro, o João Barbeiro. Existiam alguns, tinha até os da elite como o Geraldo Mesquita. Teve até aqueles que se relacionavam com o Francisco Julião, aquele das Ligas Camponesas lá do Nordeste. Eles se enquadravam no PTB. Não botavam a cara de fora porque no tempo do Guiomard, que era nazista, comunista com ele comia do lado podre. Mas tinha uma porção deles, tinha o Geraldo Brasil. Agora o Zé Augusto na minha classificação era um socialista moderado. Mas quando sabiam que alguém era comunista nem emprego público, nem firma. Era matar de fome. ${ }^{245}$

A relação histórica a nível nacional entre os comunistas e os petebistas é reproduzida no Acre por uma necessidade de sobrevivência política dos primeiros. "Como eles os comunistas não podiam apresentar candidato, votavam com a gente. Eram amigos da gente. Todo mundo sabia quem era comunista aqui. Tinha até um chefe de polícia que perseguia os comunistas. Prendia, batia."246

Também a "fala" do sr. Francisco Thaumaturgo, um dos fundadores históricos do PTB no Vale do Juruá, precisamente na cidade de Cruzeiro do Sul, apresenta a época do Território do Acre como aquela em que o poder do Estado recaía sobre a sociedade de forma coercitiva, repressiva. Ser cidadão significava ser ordeiro, cumprir as determinações sem questioná-las e muito menos seguir correntes partidárias contrárias aos interesses políticos dos que estavam no poder institucionalizado.

${ }^{245}$ Ibid.
${ }^{246}$ Ibid. 
Lá no Juruá o PTB foi fundado em 1961 porque o governo era contra. Ninguém queria reunir nas casas porque quando a polícia sabia, metia a porta adentro e o pau comia. As primeiras reuniões eram assim. . Um dia eu estava lá no Correios passando um telegrama e só via passar gente com esparadrapo na cabeça, não sei o que houve, foram fazer uma reunião do PTB e a polícia chegou e meteu o pau. A patrulha não dava trégua. Eles andavam com os livros, os documentos tudo dentro do saco, de um sacolete, desse que o seringueiro usa. Nada se preservou. Os livros ficavam na mão de um e de outro. Antes de entrar no PTB, eu cheguei a pertencer a UDN. Fizemos até a campanha do Brigadeiro Eduardo Gomes e a ele devemos a inclusão de Cruzeiro do Sul na rota do Correio Aéreo Nacional. Depois fiquei no PTB definitivo[... . $]^{247}$.

Cláudio Nobre, integrante da família do Sr. Quirino Nobre, abastado proprietário de seringais e casas de comércio em Cruzeiro do Sul e também integrante do PSD, rememora em sua narrativa os primórdios do Movimento Autonomista naquela localidade, assinalando ainda o porquê da resistência dos grandes comerciantes em apoiar o projeto de Guiomard Santos de elevação do Acre a Estado.

Meu nome é Cláudio Perez Nobre. Meu pai veio do Ceará e minha mãe é peruana. Meu avô era militar e participou de uma revolução lá no Peru e, para não ser preso, fugiu para os seringais acreanos. Em Feijó [município do Vale do Juruá] constituiu família e aí apareceu os Perez aqui em Cruzeiro do Sul. [. . .] O movimento autonomista já vinha desde o Coronel Mâncio Lima e outros de Cruzeiro do Sul. Era um movimento grande. Mas depois do Coronel Mâncio ficou meio adormecido. Quando o Guiomard Santos apareceu falando do projeto do Acre-Estado, os grandes comerciantes de Cruzeiro do Sul e de outros municípios ficaram com medo do imposto. Então eles não abraçaram a causa. Meu pai foi um dos que correu do Juruá com medo do imposto. Nós abraçamos a causa autonomista e ficamos eu e meus outros irmãos politicamente contra o pai $^{248}$.

Assinala, ainda, as perspectivas que motivaram a aceitação do projeto de elevação do

Acre a Estado, inclusive enfatizando a dupla postura de alguns petebistas.

Aí meu pai achando que ia perder. O Estado viria de qualquer maneira. Vendeu os seringais e foi embora daqui. O general Guiomard Santos era do PSD e o PTB ficou completamente contra mas eu acho que não era por

${ }^{247}$ THAUMATURGO, Francisco: depoimento. [4 de junho de 1996] Entrevistadora: Maria José Bezerra. Rio Branco.

${ }^{248}$ NOBRE, Cláudio: depoimento [11 de novembro de 1996]. Entrevistadora: Maria José Bezerra. Rio Branco. 
convicção, era mais para dar uma satisfação pessoal daqui do Acre; Aí depois o pessoal começou a achar que o Acre sendo Estado o progresso viria mais rápido do que se a gente ficasse como Território. Nós teríamos mais autonomia, uma representação política maior e talvez as condições de dinheiro no Acre melhorasse. A causa autonomista foi crescendo e as pessoas botando na cabeça que com o Estado haveria uma chance maior de vim dinheiro para o Acre e assim foi feito ${ }^{249}$.

A relevância da imprensa e das agremiações recreativas para divulgar e viabilizar os encontros dos defensores da causa autonomista no Juruá também é destacada.

No meu tempo aqui no Juruá, nós tínhamos um jornal "O Juruá" que era a favor da autonomia do Acre e lá no Clube Cruzeiro, Clube Juruá a gente se reunia para organizar os comitês e os comitês faziam a campanha, os comícios. [...] A gente viajava por todos os municípios a batelão [barco] para Rodrigues Alves, Mâncio Lima, Alto Juruá fazendo todo aquele movimento. ${ }^{250}$

Cada tempo é marcado pelas ações humanas, pelos valores e imaginário que conformam esse tempo. E, assim, o depoimento de Cláudio Nobre destaca os "coronéis de barranco", que no Juruá se notabilizaram pelo caráter aguerrido com que enfrentavam o poder central, a União, o governo federal. Senhores em seus domínios, tendo os redutos eleitorais, viam como ameaça aos seus poderes a elevação do Acre a Estado. Mais do que o temor de ter que pagar mais impostos, o que os inquietava era a possibilidade de perda e/ou controle da autonomia que gozavam naquela distante região.

Os chefes políticos daqui eram a Margarida Pedreira, além, lógico, do Coronel Mâncio Lima, o Edson Cadaxo, o Thaumaturgo e, do lado do PSD, além de D. Margarida, tinha o meu irmão, o Fernando Nobre, que era Prefeito, e o pessoal de apoio, mas a maioria queria o Estado, até o pessoal do PTB, pois embora o diretório fosse contra, eles votavam a favor do Estado. Só quem não queria eram os comerciantes com medo do imposto, pois aí o lucro ia diminuir. Teve também as lideranças de Nosser de Almeida, Moacir Rodrigues, que articulavam as classes, o Mário Lobão. Essas lideranças articulavam junto ao povo. ${ }^{251}$

${ }^{249}$ Ibid.
${ }^{250}$ Ibid.
${ }^{251}$ Ibid. 
A imprensa acreana no passado, além de diversificada, era profundamente partidária e efêmera. Os jornais apareciam, desapareciam e tornavam a aparecer, às vezes com outros nomes e proprietários, ao sabor das disputas políticas e dos "rachas" entre as facções políticas locais.

Dessa forma, também no Juruá existiram jornais dedicados à causa autonomista, porém a capacidade de penetração deles deve ser relativizada considerando o número reduzido de pessoas que sabiam ter naquele vale.

Lá em Cruzeiro tinha muitos jornais que serviam a causa autonomista. Tinha o jornal do Sr. João Mariano. Tinha grandes jornalistas no Acre o Foch Jardim, o Garibaldi Brasil aqui em Rio Branco, depois o Zé Leite, depois apareceu o Jornal do Sílvio Montenegro. ${ }^{252}$

Revela, ainda, Cláudio Nobre em sua narrativa o caráter assimétrico que o movimento autonomista teve no Juruá. Houve uma fase de grande efervescência da virada do século XIX até as duas primeiras décadas do século $\mathrm{XX}$, entrando a partir de então numa fase de arrefecimento, para novamente ressurgir em 1958, considerando-se que em 1957, Guiomard Santos dera entrada no Congresso Nacional da segunda versão do projeto de elevação do Acre a estado.

Em 1958 é que a causa autonomista cresceu em Cruzeiro do Sul. Ficou mais aguerrida. O pessoal se conscientizou de que se deveria fazer o Estado, as pessoas de cultura aderiram. Pra nós, o ponto culminante da luta foi 1958, colocamos o Guiomard como deputado federal e aí ele lutou e o Acre virou Estado. ${ }^{253}$

João Moreira de Alencar, seu João Borborema, um dos membros mais antigo do Partido Comunista Brasileira, ao lembrar seu engajamento nas lutas políticas do Acre, a partir de fins dos anos 50, vencendo as distâncias no tempo, enfatiza que:

${ }^{252}$ Ibid.
${ }^{253}$ Ibid. 
O PCB foi criado por pessoas como o Geraldo Mesquita, João Alfaiate, João Barbeiro, Cassimiro e outros. Todos gente daqui do Acre. Tinha ainda o Raimundo Melo e o meu pai. Foi criado a margem da lei nos anos 50 e se agregava ao PTB, porque este era o partido mais de esquerda que tínhamos na época. Era toda uma mistura de PTB com PCB. ${ }^{254}$

Em suas lembranças, João Borborema evidencia 1964 como um tempo político marcado pela ruptura, pela perda da liberdade. O sentido de continuidade histórica é estilhaçado. Aquele é outro tempo, o do terror.

Em 1964 veio a Revolução e todo mundo foi preso, inclusive eu, o Ariosto, o Lourival Messias e todos nós fomos condenados a um ano de cadeia. Mas nosso advogado tirou a gente com mais ou menos três meses de cadeia. Eu fiquei preso na Colônia Penal Agrícola, onde é hoje o Quartel da Polícia Militar, mas fomos, primeiro para o Exército, depois para a Colônia Penal. Porque o Exército não podia manter a gente. ${ }^{255}$

A arbitrariedade, o banimento do seio familiar estão presentes e a possibilidade de escolher que caminho político seguir é duramente arrancada de suas mãos, restando um sentimento de impotência frente à nova ordem política instituída.

Quando a Cerqueira assumiu começou a perseguição. Até pessoas como eu, o Osvaldo. . . Este tinha mais expressão, era formado e fazia parte do Gabinete do José Augusto. Nós não participávamos, éramos amigos do Zé Augusto. Aí denunciaram a gente para o Cerqueira, dizendo que eu e Lourival Messias, éramos esquerdistas, comunistas, que eu tinha curso de guerrilha e não sei mais o que. . A Aí começou a perseguição. Eu tinha uma oficina, era um simples operário. Era jovem e entusiasmado pela política e ficamos revoltado com a queda do Zé Augusto. Aí vieram mais perseguição em cima da gente e eu fiquei sem poder trabalhar por que quando eu batia na oficina chegava um policial para me prender. Rapaz desculpe, mas você está sendo chamado lá na Delegacia. Eu chegava lá e não era nada. Essas coisas aconteciam diariamente[. . . $]^{256}$.

A impossibilidade de trabalhar, o estigma de comunista, de subversivo, são marcantes nas lembranças daqueles anos de luta, de resistência.

\footnotetext{
${ }^{254}$ ALENCAR, João Moreira: depoimentos [19 de outubro de 2004]. Entrevistadora: Maria José Bezerra. Rio Branco.

${ }^{255}$ Ibid.

${ }^{256}$ ibid.
} 
Aí eu fui obrigado a comprar uma colônia, criar gado e galinha e botar roçado para poder sobreviver porque aqui eu não podia trabalhar. Nós ficamos nessa trajetória toda, até que o Cerqueira tirou o governo dele e aí acabaram as perseguições. Mas ficou assim as observações, ao ponto que tinha aqui uma praça, o bar municipal era mais embaixo, lá era onde as famílias se reuniam, os rapazes, as moças. E aí eu chegava e dizia para os meninos: vou acabar com aquela rodinha. Eles diziam: como? Eu dizia vocês vão ver. Eu chegava lá e ficava no meio deles conversando, quando via um dizia eu tenho que fazer não sei o que, e o outro dizia eu também tenho que fazer e naquilo eu ficava sozinho. Chegou a esse ponto de perseguição. Se vissem alguém comigo o governador ia saber e ia perseguir também. Eu, o Koury, o Ariosto Miguéis, o Lourival Messias, nós ficamos nessa coisa[... $]^{257}$

A memória política é a memória da opressão, da discriminação, da fuga. Naquele tempo, qualquer um podia ser preso.

Aí na época da ditadura o Aníbal Miranda era Prefeito de Rio Branco e aí a ditadura interveio na Prefeitura e ia prender o Aníbal Miranda. Eu já tinha tido a experiência de 1964 na Bolívia. Eu fui para a Bolívia para não ser preso. Eu passei seis meses lá. Aí cheguei aqui de madrugada de carro pois o advogado do D. Aníbal ajeitou as coisas por aqui e mandou nos buscar. Aí nos voltamos[... . $]^{258}$.

Em sua narrativa, o clima de insegurança, de delação no qual todos são vistos com suspeição, denota a opressão vivida. Os vínculos de amizade, de companheirismo entre os indivíduos, entre as famílias, que caracterizam a relação de convivência social, são pisoteados pelas forças políticas que venceram em 1964 e seus herdeiros.

Passou esse período, o governador era o Kalume e o nosso processo já estava arquivado no Tribunal de Belém, no Tribunal Militar, aí o Kalume com raiva do Koury [Hélio Koury] pediu o desarquivamento do nosso processo e fomos condenados a 1 ano de cadeia [. . .] No período do Mesquita voltaram as perseguições aos comunistas. O caso de Mesquita era agradar o patrão maior, os generais que mandavam no país. Inclusive fez injustiça com o Careca e o Elias Antunes, só porque ele deu uma carona para um homem que ia para uma "invasão". ${ }^{259}$

${ }^{257}$ Ibid.
${ }^{258}$ Ibid.
${ }^{259}$ Ibid. 
O entusiasmo da juventude e a crença na possibilidade histórica de construir uma sociedade mais justa e fraterna eram a força que impelia os jovens militantes do PCB, desprovidos na quase totalidade de base teórica marxista.

Naquela época a gente fazia política por idealismo, nós queríamos uma sociedade melhor. A gente lia Karl Marx obrigado, quero dizer incentivados, nós queríamos uma política proletária, onde houvesse participação de todos. Os seringalistas diziam que pobre deveria ser pobre, desgraçado devia ser desgraçado, seringueiro devia ser seringueiro, não sair do seringal, ficar produzindo borracha. O patrão botava prá fora o seringueiro sem nada. . . E a gente lendo Karl Marx, a gente queria algo melhor, a gente era chamado de comunista, de não sei mais o que. Nós éramos pelos proletários, ninguém passando fome. Já naquela época a gente defendia o direito do seringueiro plantar e colher. $\mathrm{O}$ seringueiro era proibido de plantar[... $]^{260}$.

Entre o passado e o presente, o sentimento de nostalgia de João Borborema é o do narrador que conhece sua terra, seus conterrâneos. Seu passado o habita, orgulha-se de suas lutas, apesar do desencanto com a falta de coerência daqueles que usam o poder político segundo seus interesses.

A gente se reunia lá na minha casa. Eu aproveitava quando a minha mãe e meu pai não estavam. Aí a gente ia lá para o porão e de lá a gente passava as notícias. A gente não tinha jornal. Então ficava eu e o Lourival Messias até meia noite, uma hora fazendo panfleto que a gente distribuía nas portas das casas, no mercado. A gente distribuindo aquele negócio, se fosse pego a gente ia preso. Nós fizemos isto. Fez parte de nossa vida. As vezes me dá saudade porque a gente vivia pelo entusiasmo pela beleza, aquele sonho de mudar o mundo, é uma inocência [. . . Então eu deixei de acreditar no idealismo pela conveniência de viver. Não vejo mais razão para defender porque existe pessoas que hoje é contra e amanhã é a favor. Pessoas que hoje estão de cima[... $]^{261}$

Francisco Eduardo Pinheiro Mansour, conhecido como "Dadinho", irmão de Elias Mansour, homenageado com a mudança do nome da Fundação Cultural do Estado do Acre para Fundação Elias Mansour, numa ampla seqüência de depoimentos, assinalou-nos detalhes

${ }^{260}$ Ibid.
${ }^{261}$ Ibid. 
da personalidade inquieta e contestadora de Elias Mansour, uma das grandes lideranças da esquerda no Acre, que teve um forte engajamento no movimento estudantil do Rio de Janeiro e, como conseqüência da militância, foi cassado por dez anos.

Destaca-se da narrativa deste o sonho de um idealista, que, juntamente com outros jovens, nos conturbados anos 60, ousou como parte de uma revolução não apenas política, mas também econômica e cultural, insurgir-se contra a ordem política instituída após 64 .

O projeto maior dele era a Revolução. Ele não tinha preocupação com roupa, sapato, com a saúde, alimentação, com nada. Se estava bem senão estava. As vezes a pressão dele estava muito alta e ele pedia prá não dizer nada prá mamãe. Ele trabalhava desesperadamente e ele centralizava muito as coisas, não porque quisesse, mas porque era uma grande liderança. Ele nunca se preocupou com ele[... $]^{262}$.

Tendo a alma contagiada pelo fermento da inquietação, o jovem Elias Mansour fez da Revolução, da mudança, o seu projeto maior de vida. O que nos faz lembrar das conversas de Lênin com os bolcheviques nos "preparativos" da Revolução Russa. O compromisso do revolucionário é com a revolução. . . No entanto, os revolucionários eram pessoas humanas que também tinham suas aspirações pessoais, afetivas, seus valores, suas tradições. . .

Eles [companheiros de luta do Elias Mansour no Rio de Janeiro] achavam esse negócio de traição muito burguês, extremamente burguês, não tinha essa coisa de você flertar com todo mundo. [. . .] Uma vez eu vi Elias dando uma bronca numa menina. Ela era recém admitida e chorando por que o namorado dela não dava atenção prá ela, ele disse: tu é revolucionária ? O que é que tu és? Veio prá cá choromingar, volta para a casa dos teus pais, lá tu namoras com quem tu quiseres. Aqui se tem uma tarefa maior[... . $]^{263}$ [Grifos nossos].

Tempo, memória e política nas falas dos nossos depoentes caminharam juntos, às vezes numa relação tensa de busca da apropriação e reconstrução da memória pela história.

\footnotetext{
${ }^{262}$ MANSOUR, Francisco Eduardo Pinheiro: depoimento [15 de julho de 1996]. Entrevistadora: Maria José Bezerra. Rio Branco.

${ }^{263}$ Ibid.
} 
Ao recompor suas lembranças, esses guardiões/guardiãs da memória dos partidos políticos existentes no Acre-Território nos possibilitaram aprender com a escuta do outro, a partir da postura teórica de que, enquanto sujeitos históricos de um tempo, projetam suas aspirações, utopias e desilusões com os tons do presente, tonalizados pelas nuances do passado, redesenhando a própria vida.

Vários desses homens e mulheres que entrevistamos no ano de 1996, quando a idéia desta tese corporificou-se, faleceram entre aquela data e os tempos atuais, porém, os seus testemunhos se revestem de grande significado, sobretudo porque não havia por parte dos partidos políticos do período em foco interesse de preservar os registros alusivos à trajetória de cada agremiação partidária, constituindo esses testemunhos vivos. 


\section{CAPÍTULO 4 A INVENÇÃO DO ACRE VIÁVEL}

O que será? O que será? Que estão falando alto pelos botecos, que anda nas cabeças, andas nas bocas...

Chico Buarque

Diante do contexto de falência da economia extrativista, a invenção do Acre viável se concentrou, primeiramente na esfera política, na perspectiva de que com a emancipação política seriam formados novos quadros por jovens oriundos da região, os quais poderiam ter acesso a estrutura do poder local, instituindo um Estado democrático e popular.

No entanto, essa possibilidade histórica foi estilhaçada com o golpe militar de 1964.

Portanto, a disputa pelo poder político local caracterizava o Acre pós 1962, sobretudo diante da força política que Guiomard Santos e o PSD passaram a ter, no PTB a perspectiva que se configurou foi "abrir” espaço para as novas lideranças não acatando a imposição do candidato do General Passos. Como resultado dessa "rebeldia”, a convenção do PTB escolheu como candidato ao governo do recém-criado Estado o jovem José Augusto de Araújo.

Assinala Costa Sobrinho (1992, p. 109) que, para viabilizar a eleição de José Augusto, o PTB ampliou o leque de alianças coligando-se com a UDN e PSP, que embora tivessem uma densidade eleitoral baixa, traziam à cena política personalidades de notório reconhecimento público.

Eleito como primeiro governador do Acre constitucional, no seu discurso de posse, na Assembléia Legislativa do Estado do Acre, José Augusto de Araújo estabeleceu como prioridades do seu governo as áreas da agricultura, educação e saúde.

Seu programa de governo estabelecia, em linhas gerais, que

[. . .] através da Secretaria de Agricultura do Estado faremos elaborar um plano de emergência, dentro de nossas reais possibilidades, objetivando a 
produção agrícola em alta escala [. . .] Na pecuária, merecerá nossa atenção, inicialmente a criação de bovinos, suínos e aves, bem como de peixes. No setor de indústrias rurais objetivaremos a preparação, conservação e industrialização dos produtos agropecuários e com relação ao ensino agrícola, dispensaremos toda colaboração a Secretaria de Educação [. . .] O plano de emergência refere-se a dinamização das atividades da Secretaria de Agricultura no que concerne a produção de gênero alimentícios, que ainda é insuficiente para atender o consumo da população. [...] sem detrimento da indústria extrativa da borracha principal fonte de renda do governo pois $80 \%$ da população do Acre vive no meio rural [. . . ] cumpre-nos [ainda] garantir a conservação, o beneficiamento e industrialização dos produtos agropecuários. [...] promover a escolarização gradativa das crianças acreanas de sete a quatorze anos. [. . .] abrir amplas oportunidades educacionais nos estabelecimentos de ensino médio criando e reequipando os cursos ginasial, científico, colegial, normal, técnicocomercial e industrial-agrícola. [...] criação de uma Faculdade de Filosofia, Ciências e Letras e concessão de bolsas de ensino superior para escolas superiores do país. [. . . ] Construção de estradas. [. . .] recuperação da rede hospitalar, destacando o serviço de profilaxia da tuberculose, grave problema de saúde no Estado, conclusão de obras e aparelhamento do Hospital de Tuberculosos, apoio integral ao serviço de profilaxia da lepra e conclusão dos leprosários já iniciados, [. . .] Incentivos a campanha de erradicação da malária, no que diz respeito as endemias rurais, e por fim, dar as cidades acreanas condições sanitárias, partindo dos serviços de água e esgotos. . . ${ }^{264}$.

Numa seqüência de depoimentos comoventes, a viúva de José Augusto, D. Maria Lúcia Melo de Araújo, na condição de partícipe da luta política do marido e companheiro de ideal, assinalou:

O discurso que ele fez quando tomava posse na Assembléia Legislativa é muito bonito e profundo e as pessoas procuram esconder e até dizem que o governo do José Augusto foi infantil, jovem demais, mas era a cabeça dele [. . . E É porque querem esconder o tanto que José Augusto procurou fazer pelo Acre. Infelizmente veio a Revolução de 1964 e ele teve a infelicidade de ser governador num período daquele e aí teve que abandonar. . . ${ }^{265}$

A fala de D. Maria Lúcia denota que a linguagem não é neutra. Ela contamina o que deve ser dito. As palavras que usa e a conotação que dá a elas traduzem um testemunho de uma época que para muitos dos que vivem no Acre se constituiu num período “maldito”.

\footnotetext{
${ }^{264}$ ARAÚJO, José Augusto de. Discurso do governador José Augusto de Araújo pronunciado por ocasião de sua posse na posse na Assembléia Legislativa do Estado. Rio Branco, Acre. Março de 1963 (texto impresso).

${ }^{265}$ ARAÚJO, Maria Lúcia Melo de: depoimento: [11 de junho de 1996]. Entrevistadora: Maria José Bezerra, Rio Branco.
} 
Ele [José Augusto] era um jovem idealista. É uma pena o que aconteceu. . . Ele foi um fenômeno na política nos anos 60. Era um líder impressionante. Falava muito bem. Tinha uma oratória maravilhosa. Quando ele ficava no palanque não queria mais sair. Eu nunca vi uma coisa daquela. . . Mas ele incomodava muita gente com suas idéias, principalmente os que estavam no poder. Queriam colocar outra pessoa que nem era daqui, mas o povo ficou do lado dele e ele sai candidato ao governo do Estado. E naquela época falar de Reforma Agrária era muito difícil, era coisa de comunista, todo mundo tinha medo, mas ele era a favor. Naquela época era os E.U.A que mandavam aqui e ainda mandam. . Q Quando veio a Revolução e aí o coronel Cerqueira pediu que ele renunciasse, ele até pensou em resistir, mas como? Lá no fundo do Palácio os homens armados de metralhadora e a guarda despreparada, aí ele renunciou. . . ${ }^{266}$

Reconstituindo a trajetória política do jovem juruaense, José Augusto, D. Maria Lúcia

ressalta:

Ele morava lá no Rio de Janeiro, num quarto de pensão. Aí ele apoiava as pessoas que chegavam lá e não tinham para onde ir. Essas pessoas vinham no avião da FAB que tinha naquela época. Ele colocava no quarto dele. As vezes tinha oito pessoas no quarto dele. Tornou-se conhecido por este trabalho. Ele encaminhava as pessoas para os hospitais, colégios, tudo. . . Aí ele ficou sendo conhecido na política. Ele estudava muito, ele sabia o que o povo passava. Era uma política assistencialista. Ele era contra mas ele achava que não tinha outro jeito, outros meios. . . [. . . ] Depois que foi cassado, ele ficou muito triste. Adoeceu, teve o primeiro infarto e depois mais cinco ou seis. Quando ele faleceu, ele ia completar 40 anos. $^{267}$

Outro aspecto a considerar do governo José Augusto é a formação das ligas camponesas no Acre, a partir de 1962, através da atuação de Raimundo Moreira Ferreira, o Raimundo Borborema, que no Rio de Janeiro manteve contato com Francisco Julião, líder nacional das ligas camponesas. Ao retornar ao Acre, no início dos anos 60, com apoio dos militantes da esquerda do PTB local, a qual se identificava com a política social de reformas do governo Goulart, formou-se a liga camponesa de Rio Branco.

Abordando esta questão, Costa Sobrinho reproduz um trecho do semanário a "Liga”, de $1^{\circ}$ de junho de 1963 , que diz o seguinte:

${ }^{266}$ Ibid.

${ }^{267}$ Ibid. 
O atual governador se chama José Augusto de Araújo. Foi eleito no dia 7 de outubro, com apoio dos setores mais progressistas do Estado do Acre, principalmente da massa camponesa. Antigo Presidente da União Brasileira dos Estudantes Secundaristas, tem apenas 37 anos e tem merecido, até agora, a confiança dos seus conterrâneos. Toda sua campanha foi feita em sintonia com as reivindicações mais sentidas dos trabalhadores das cidades e dos campos, principalmente dos últimos, que constituem $80 \%$ da população do Estado. Está rodeado de gente nova e idealista. Tem planos de colonização, desapropriação de terras e instalação de cooperativas mistas de produção e consumo em todos os municípios do Estado. ${ }^{268}$

Acrescenta ainda que a liga camponesa, presidida por Raimundo Borborema, contou com a presença de Lourival Messias (professor primário) e Estanislau (ex-seringueiro que ganhava a vida como marreteiro), os quais contribuíram para que as ligas "nascessem e ampliassem os seus quadros com incrível rapidez, graças ao dinâmico trabalho de seu presidente Raimundo Borborema, que atualmente encontra-se no Rio de Janeiro à frente de uma delegação de camponeses”. 269

Destaca também Costa Sobrinho que, frente ao quadro nacional político que caminhava para a ruptura, o governo José Augusto, com apoio de Ariosto Pires Miguéis, cria o Sindicato dos Trabalhadores Rurais em Rio Branco e, com o decorrer do tempo, vários integrantes das ligas do Acre passaram a integrar o sindicato criado. Por sua vez, a Igreja Católica, através do trabalho do Padre Alberto Morine, também iniciava uma política de associativismo fundando a cooperativa Nossa Senhora da Conceição.

Esta ação arrebanhou vários integrantes das ligas.

O sindicato dos trabalhadores Rurais de Rio Branco foi fundado em 2 de fevereiro de 1964 e chegou a ter 3.000 filiados, porém, em abril de 1964, em decorrência do golpe militar, foi fechado e suas lideranças, presas.

No entanto, José Augusto não teve a oportunidade de corporificar suas metas de governo frente ao curto espaço de tempo em que permaneceu na gestão do Estado, pois, à

\footnotetext{
${ }^{268}$ COSTA SOBRINHO, Op. Cit. p. 112.

${ }^{269}$ Ibid.,. p. $112-113$.
} 
medida que o governo de Goulart entrava em crise e as forças golpistas se fortaleciam, passou a sofrer sistemática oposição das forças políticas locais conservadoras, sendo acusado de favorecer e/ou executar a malversação do patrimônio público, pesando ainda sobre ele a acusação de comunista.

Deixar o governo foi um sofrimento muito grande porque ele tinha o ideal de melhorar o Acre. Ele tinha condição porque tinha o apoio do governo federal. O governo federal apoiava ele em tudo que ele queria fazer aqui dentro do Estado. Ele mandou vir técnicos de todos os setores para a educação, saúde e agricultura. O que ele achava que o Acre tinha potencial prá ser desenvolvido aqui com a castanha, a borracha, com a madeira. Ele falava nas estradas vicinais. Tudo isso ele falava. Ele queria tudo que era importante, o rebanho de gado. Ele trouxe gado prá cá. Ele tinha uma visão fora de sério. Ele achava que alimentando as pessoas faria com que as pessoas melhorassem o seu nível intelectual e aí talvez não precisasse tanto de hospital, pois o povo com saúde não procura hospital [. . . ]. Ele pensava no Banco do Estado como uma agência fomentadora de desenvolvimento local, liberando recursos para o colonos. . . Mas aí o que houve? Ele passou como irresponsável [. . . ] Ele tinha um coração muito bom. Tão bom que não resistiu a tanta pressão e estourou. Eu comparo ele a Juscelino Kubitscheck, tudo de bom ele queria para o Brasil e o José Augusto queria tudo de bom para o Acre, mas aí veio a Revolução e tudo acabou. ${ }^{270}$

Outro dado relevante a considerar é que, na condição de Estado da federação brasileira, o Acre passou a ter uma maior representação no Congresso Nacional, que passou a ser composta de sete deputados federais e três senadores - dois com mandato de oito anos e um com mandato de quatro anos.

No entanto, com a deposição de Goulart e a conseqüente intervenção política nos Estados, José Augusto foi arrancado do poder, dando início ao ciclo de governadores indicados pela Presidência da República, no contexto do bipartidarismo, tendo em vista que os partidos políticos existentes até então foram extintos.

Iniciando o ciclo de governos indicados, teve-se a administração do capitão do Exército Edgard Pedreira de Cerqueira Filho, que se notabilizou pelo caráter autoritário que

${ }^{270}$ Ibid. 
imprimiu ao seu governo, marcado pelas perseguições políticas, várias delas culminando em prisões e cassações. Em discurso proferido na Câmara Federal, o deputado Rui Lino enfatiza:

"Senhor Presidente, senhores deputados, as perseguições e as violências no meu Estado, o Acre, repetem-se dia a dia, hora a hora. Lamento profundamente, desta tribuna, que o senhor governador do meu Estado sirva de joguete e teleguiado de um partido tradicionalmente adversário do Partido Trabalhista Brasileiro. Num Estado que tem tudo a fazer, a realizar e a executar, não é possível que o governador se entregue à sede de ódio e vingança de um partido. Estão lá os hospitais para recuperar, as estradas para construir, de tudo enfim necessita o Estado do Acre. ${ }^{271}$

Mais adiante, faz a leitura de um telegrama recebido informando que vários funcionários públicos estavam sendo arbitrariamente transferidos.

Cumpre-nos levar ao conhecimento de Vossência vg a bem do Serviço Público nosso Estado vg perseguições políticas movidas pelo Exmo. Sr. Governador Edgard Pereira Cerqueira Filho vg contra funcionários da administração que não estão conformes com as ilegalidades et atos lesivos mais altos interesses Estado do Acre vg transferindo sumariamente para regiões distantes vg sem observar dispostos Estatutos Funcionários Públicos et ultimamente estão sendo transferidos veterinários vg oficiais guardas territorial para lugares sem mínima condição de vida vg culminando com a transferência de três dos referidos oficiais para localidade nem ao menos possuidora de destacamento policial militar pt Cds Sds Guilherme Zaire vg José Fonseca vg Francisco Thaumaturgo vg Adonai Santos vg Benjamin Ruela vg Geraldo Fleming vg José Feres et Nabor Júnior ${ }^{272}$.

Com o término do governo de Cerqueira Filho, sucederam-se as administrações de Jorge Kalume (1967-71), Francisco Wanderley Dantas (1971-75), Geraldo Gurgel de Mesquita (1975-79) e Joaquim Falcão de Macedo (1979-82).

Por sua vez, como o contexto de crise da borracha vinha se acentuando desde meados da década de 1940, dedicaremo-nos a tecer considerações a esse respeito que são fundamentais para o entendimento das mudanças que ocorreram no Acre a partir dos anos 70.

${ }^{271}$ LINO, Rui. Discurso. Anais da Câmara Federal, sessão de 1 de junho de 1965.

${ }^{272}$ Ibid. 
Assim, merece destacarmos as realizações das II e III conferências nacionais da borracha no período de 1947 - 50, que impeliram o Estado brasileiro a manter-se firme quanto ao compromisso assumido em 1946, e, se possível, reforçar o extrativismo.

Todavia, como assinala Rego (2003, p. 370), o apoio financeiro do Banco da Amazônia não ocorreu como o prometido para as aquisições das safras de borracha, acrescido do fato de que os preços relativos da borracha declinavam.

Segundo Fonseca (1970, p. 185), “o preço da borracha brasileira não se modificou para o produtor desde 1944, ou seja, há 5 anos, ao passo que será difícil indicar outro produto nacional que tenha conservado tal estabilidade e em contrapartida, a produção brasileira de borracha caiu de 32.045 t (1947) para 18.619 em 1950”273.

Como reverter esse quadro?

O governo buscou, através de medidas legais, impelir as grandes indústrias de artefatos de borracha a se engajarem na racionalização da produção de borracha vegetal (ALVES PINTO, p. 112-6) e, segundo Rego (2003, p. 370-1), também estabeleceu como condição para o recebimento de quotas de borracha natural ou importada que as empresas produtos de artefatos aplicassem 20\% dos seus lucros no plantio da seringueira (Decreto $\mathrm{n}^{\circ}$ 30.694, 31 de março de 1952), no entanto estas medidas se mostraram inócuas.

No governo do presidente Kubitschek, diante das preocupações referente à expansão do transporte rodoviário, além do desenvolvimento da indústria automobilística, que conduziu a expansão de artefatos pesados de borracha, houve um aumento da demanda dessa matéria-prima.

Todavia, a manutenção do monopólio estatal do comércio de borracha, o qual visava proteger, e a escassez de divisas não permitiram à indústria fazer uso da possibilidade de substituir a reduzida produção da borracha natural amazônica pela sintética ou pela vegetal importada.

${ }^{273}$ DEAN, Warren. A luta pela borracha no Brasil. São Paulo: Nobel, 1989. In: REGO, Op. Cit. p. 370. 
E, a partir de então, o descompasso entre a produção e o consumo de borracha se acentuará conforme expressa o quadro abaixo.

\section{Quadro 11}

\section{Produção e Consumo de Borracha}

\begin{tabular}{|c|c|c|c|}
\hline ANOS & PRODUÇÃO & CONSUMO & PRODUÇÃO CONSUMO (Percentual) \\
\hline 1950 & 18.619 & 23.894 & 77,60 \\
\hline 1951 & 20.093 & 25.032 & 80,30 \\
\hline 1952 & 25.592 & 28.592 & 80,80 \\
\hline 1953 & 25.482 & 32.642 & 78,00 \\
\hline 1954 & 22.523 & 38.425 & 58,60 \\
\hline 1955 & 21.911 & 39.946 & 54,90 \\
\hline 1956 & 24.224 & 37.497 & 64,60 \\
\hline 1957 & 24.462 & 39.385 & 62,10 \\
\hline 1958 & 21.135 & 43.391 & 48,70 \\
\hline 1959 & 21.738 & 45.629 & 47,60 \\
\hline 1960 & 23.462 & 45.253 & 51,80 \\
\hline
\end{tabular}

Fonte: SUDHEVEA - Mercado Brasileiro de Borracha (Relatório do Grupo de Estudos, Portaria E-2/73, p. 94) In: REGO, Op. Cit. p. 371).

Portanto, o quadro nacional se caracterizara pela desproporção entre as necessidades de maiores demandas de borracha e a incapacidade da produção interna de atendê-las, agravada pelas dificuldades à importação. No entanto, esse fato fará, necessariamente, com que haja pressões no sentido de substituir a borracha vegetal pela sintética.

Outro ponto a destacar é que, a partir da segunda metade da década de 1950, o subsetor de artefatos pesados passou a dominar a indústria de artefatos de borracha e a “produção de pneumáticos no Brasil elevou-se de 1,3 milhão de unidades, em 1950 para 3,3 milhões em 1960. As indústrias de pneumáticos e câmaras de ar e outros artefatos pesados respondiam por $75 \%$ da borracha consumida no país”274. E as questões relativas à borracha, 
no que concerne à indústria, eram resolvidas entre o grupo de seis grandes empresas, a saber: Firestone, Goodyear, Pirelli, Dunlop, Goodrich e General.

O que fazer?

Frente a essa crise de abastecimento da borracha, assinala-nos Rego (2003, p. 372), que o governo Kubischek institui a supressão do controle governamental no que tangia às importações de borracha (art. $6^{\circ}$ da Lei n. 44.728 de 22.10.1958), reduziu inclusive os direitos aduaneiros (art. $2^{\circ}$ da Lei 44.728) e autorizou a implantação da fábrica de borracha sintética da Petrobras, a FABOR, com capacidade para produzir 40.000 t. Buscou também promover a criação de seringais de cultivo por meio do PROJETO ETA - 54, o qual, em função de fatores como condições de tecnologia, infra-estrutura, disponibilidade de recursos financeiros públicos e a falta de interesses do setor privado, não provocou os resultados esperados.

Dessa forma, o Estado garantia a rentabilidade dos capitais envolvidos na indústria de artefatos, seja pela concessão de divisas, seja pela produção de borracha sintética em detrimento dos interesses do capital comercial extrativista da Amazônia.

A partir de então, o consumo interno de borracha sintética e as importações de borracha natural cresceram consideravelmente, atingindo as importações de borracha quase 50\% do consumo (REGO, 2003, p. 372).

Dessa forma, a década de 1960 foi marcada pelo desenvolvimento da produção e do consumo de borracha sintética, permitidos graças ao funcionamento da FABOR e da COPERBO (Companhia Pernambucana de Borracha Sintética), fazendo com que o consumo da borracha vegetal declinasse conforme evidencia o quadro a seguir: 


\section{Quadro 12}

\section{Borracha Sintética: Produção, Importação e Consumo no Brasil - 1960 a 1970}

\begin{tabular}{|c|c|c|c|r|r|r|c|}
\hline Anos & $\begin{array}{c}\text { Produção de } \\
\text { Borracha } \\
\text { Sintética (t) }\end{array}$ & Índices & $\begin{array}{c}\text { Importação de } \\
\text { Borracha } \\
\text { Sintética (t) }\end{array}$ & Índices & $\begin{array}{c}\text { Consumo de } \\
\text { Borracha } \\
\text { Sintética (t) }\end{array}$ & Índices & $\begin{array}{c}\text { Consumo de } \\
\text { Sintética/Cons } \\
\text { umo de } \\
\text { Borrachas* } \\
\text { (\%) }\end{array}$ \\
\hline 1960 & n.d. & n.d. & 16.614 & 100 & 16.612 & 100 & 23,25 \\
\hline 1961 & n.d. & n.d. & 22.577 & 136 & 20.775 & 126 & 29,54 \\
\hline 1962 & 15.990 & 100 & 16.581 & 100 & 29.210 & 177 & 35,52 \\
\hline 1963 & 29.959 & 187 & 8.367 & 50 & 34.372 & 209 & 40,80 \\
\hline 1964 & 32.496 & 203 & 12.887 & 78 & 40.907 & 249 & 47,40 \\
\hline 1965 & 38.691 & 242 & 8.838 & 53 & 37.859 & 232 & 51,05 \\
\hline 1966 & 54.216 & 339 & 9.762 & 59 & 51.408 & 313 & 54,35 \\
\hline 1967 & 51.540 & 322 & 10.263 & 62 & 57.024 & 351 & 55,62 \\
\hline 1968 & 58.856 & 368 & 15.597 & 94 & 70.542 & 433 & 55,62 \\
\hline 1969 & 61.671 & 386 & 11.350 & 68 & 71.211 & 438 & 57,28 \\
\hline 1970 & 75.459 & 472 & 12.701 & 76 & 85.354 & 523 & 59,18 \\
\hline
\end{tabular}

* Inclusive borracha regenerada

Fonte: SUDHEVEA, Mercado Brasileiro de borracha, Relatório do Grupo de Estudos, Portaria E-2/73, p. 94. Índices calculados por JFR. In: REGO, Op. Cit. p. 373.

Diante do fato do crescimento da produção da borracha sintética, sua importação decresceu, contribuindo para aumentar o seu consumo (423\% entre 1960 e 1970), que evolui de 23,25\% (1960) para 59,18\% em 1970 sobre o consumo total de borracha (REGO, 2003, p. 373).

Frente às preocupações que a situação vivida estava gerando para o setor extrativista, o governo João Goulart (1963) respondeu as inquietações deste com uma política de fixação de preços mais elevados para o produto natural, que deveriam ser reajustados acima dos índices da inflação, todavia mantendo intocado o incentivo ao consumo de borracha sintética. Além do quê, a taxa de $10 \%$ atribuída ao preço da borracha importada (artigo $3^{\circ}$ do Decreto 50.422, 
7 de abril de 1961) reforçava a proteção à borracha amazônica e os recursos advindos do recolhimento da referida taxa destinar-se-iam à constituição do fundo de fomento à produção visando estimular na Amazônia a produção de borracha de seringais nativos e a heveicultura.

Por sua vez, os reduzidos preços da borracha praticados pelo Estado incentivaram as indústrias de artefatos a acelerarem o seu consumo. Em direção inversa, o elevado preço de garantia da borracha natural amazônica estimulou a sua produção e reduziu o consumo. Em decorrência desse fato, em 1965 registrou-se um excedente de borracha vegetal não comercializado de quase $10 \%$ da produção.

Entrementes, à fase expansiva do Plano de Metas do governo Kubistschek seguiu-se a crise de 1962 - 67, e neste caso, foi o Estado brasileiro de exceção, oriundo do golpe militar de 1964, que fez intervenções visando a retomada do crescimento econômico.

E, nesse aspecto, a política de concentração de renda e os estímulos ao capital estrangeiro favoreceu a expansão da indústria de automóveis e, por conseguinte, a de artefatos pesados de borracha, fazendo com que nas gestões dos ministros Roberto Campos e Otávio G. Bulhões a política gomífera fosse reorientada com a finalidade de assegurar o suprimento de borracha frente a expectativa de reativação da economia.

O novo direcionamento, consubstanciado na Lei n. 5.227, datada de 18 de janeiro de 1967, almejava atender as reivindicações dos monopólios de indústria de artefatos na perspectiva de garantir o suprimento de matéria-prima aos preços do mercado internacional, oportunizando a redução dos custos de produção, a ampliação do mercado interno e o incremento as exportações.

Para concretizar a meta pretendida, o governo suprimiu todo o monopólio estatal de comercialização de borrachas e a garantia de preços, que era exercida pelo Banco de Crédito da Amazônia S. A, liberou as importações e subsidiou a produção de elastômeros sintéticos. 
Essa política visava liberar o mercado que operava no sentido da equiparação dos preços da borracha vegetal nacional aos da borracha asiática.

Dessa forma, os custos de produção do seringal cultivado na Ásia deveriam regular o preço da borracha produzida internamente em seringais nativos e não o contrário como vinha ocorrendo até aquela data.

Nessa perspectiva, o artigo 12 determinava a gradual redução dos preços internacionais no período de 1968 - 72.

Dessa forma, reforçava-se a tendência já esboçada no período juscelinista de reversão dos fundamentos da política gumífera do Estado brasileiro, em vigor desde o início do século.

A nova política atendia ao essencial das reivindicações dos monopólios que fabricavam os artefatos de borracha

Merece destaque o fato de que, no seu artigo 59, a Lei de n 5.227 revogava o Decreto de $\mathrm{n}^{\circ}$ 30.694, de 31 de março de 1952, que obrigava as indústrias de pneumáticos a investir em seringais de cultivo.

E, essa mesma lei, transformou a CEDB em Conselho Nacional de Borracha (CNB), com a função precípua de torná-lo um órgão formulador, orientador e coordenador da política econômica da borracha.

A lei acima citada também criou a Superintendência da Borracha (SUDHEVEA), com a finalidade de executar a política econômica de borracha e estabelecer a Taxa de Organização e Regulamentação do Mercado de Borracha (TORMB), incidente sobre borrachas naturais e químicas, cuja arrecadação seria destinada a financiar a organização de estoques de reserva e o custeio das transações de compra e venda de borracha pela SUDHEVEA, por meio do Fundo Especial da SUDHEVEA, instituído pelo artigo 40 da mencionada lei. 
Considerando que as perspectivas de crescimento industrial para os fins da década de 1960 apontavam para um crescente déficit de borracha vegetal de produção interna, por outro lado, evoluía a substituição da borracha vegetal pela sintética, de modo que, em 1966, 54\% da borracha utilizada era sintética, dos quais cerca de 1/5 era importado.

Fica evidente, portanto, a partir do governo do Presidente Castelo Branco, o objetivo de baratear os custos relativos à matéria-prima para possibilitar a elevação da taxa de lucros na indústria de artefatos, criando, dessa forma, as condições necessárias à recuperação e expansão compatível com o ritmo esperado de desenvolvimento da indústria de transportes.

Portanto, a nova política instituída tendia a concentrar o suprimento da indústria nas importações e na produção sintética (os preços eram mais baixos) e deprimir a produção de borracha vegetal nacional, em face da rigidez dos seus custos e subordinada ao capital mercantil. Nesse aspecto, torna-se necessário ressaltar que os preços, nesse período, eram reajustados abaixo dos índices de inflação.

Com efeito, em 1967, a produção da borracha natural nacional se reduziu ao nível de 1959, a despeito do crescente consumo industrial, conforme demonstra o quadro abaixo.

\section{Quadro 13}

\section{Produção da Borracha Natural}

\begin{tabular}{|c|c|c|c|}
\hline ANOS & PRODUÇÃO & CONSUMO & PRODUÇÃO CONSUMO (Percentual) \\
\hline 1959 & 21.738 & 45.167 & 48,13 \\
\hline 1960 & 23.462 & 44.550 & 52,66 \\
\hline 1961 & 22.736 & 39.343 & 57,79 \\
\hline 1962 & 21.741 & 40.675 & 53,45 \\
\hline 1963 & 20.205 & 36.058 & 56,03 \\
\hline 1964 & 28.323 & 32.729 & 86,54 \\
\hline 1965 & 29.290 & 26.554 & 110,30 \\
\hline 1966 & 24.347 & 30.862 & 78,89 \\
\hline 1967 & 21.494 & 32.133 & 66,89 \\
\hline 1968 & 22.958 & 38.156 & 60,17 \\
\hline 1969 & 23.950 & 35.071 & 68,02 \\
\hline 1970 & 24.976 & 36.739 & 67,98 \\
\hline 1971 & 24.231 & 41.761 & 58,02 \\
\hline
\end{tabular}

Fonte: SUDHEVEA - Mercado Brasileiro de Borracha (Relatório do Grupo de Estudos, Portaria E-2/73, p. 94) In: REGO, Op. Cit. p. 376). 
Analisando os dados numéricos expressos na tabela acima, percebemos que a relação entre a produção nacional e o consumo total de borracha natural cresceu em ritmo acelerado entre 1959 (48,13\%) e 1965 (110,3\%), apresentando tendência declinante a partir de 1966 (78,89\%), devido à produção ter se mantido estagnada, enquanto o consumo experimenta razoável aumento, tendo em vista o incremento mais lento da taxa de substituição da borracha natural pela sintética.

Destaca-se, também, que a participação da borracha sintética no cômputo geral do total de borracha eleva-se em média 22,29\% ao ano entre 1960 e 1966 e apenas 2,22\% entre 1966 e 1970.

Frente ao exposto, a expectativa, a partir de 1967, era de incapacidade da borracha natural sustentar a alíquota que historicamente lhe cabia no suprimento de borracha.

Diante do fato inconteste da redução da produção da borracha vegetal e da mobilização dos interesses extrativistas da Amazônia por conta da depressão dos preços, da falta de financiamento à produção e do debilitamento do Banco de Crédito da Amazônia, o problema da política gumífera passou para a “ordem do dia” do governo que assume em 1967, cujo ministro da Fazenda era Delfim Netto.

A gravidade da situação chegou a tal ponto que na Câmara Federal foi organizada uma CPI (Comissão Parlamentar de Inquérito) para examinar a questão da borracha.

Acerca dos trabalhos desenvolvidos pela mencionada CPI e das forças que se manifestavam pleiteando a implementação de uma política protecionista (burguesia mercantil extrativista) ou liberal (uma fração da burguesia monopolista do setor de artefatos de borracha), Dean (1989, p. 185 - 186) afirma:

A esfrangalhada legião de seringalistas e aviadores juntou forças para mais uma batalha política. . . Assim, uma coligação de interesses nordestinos e amazônicos determinou-se a impressionar de novo a opinião pública, com a imagem de uma vasta extensão selvática, preservada para a nação graças à persistência de um punhado de bravos fronteiriços abandonados a si 
mesmos e cujo meio de subsistência era a borracha. Os representantes do comércio extrativo - como Guilherme Zaire, seringalistas e deputado estadual do Acre; Albertino Lopes, presidente da Câmara do Comércio de Rondônia; e Manuel Miranda Sobrinho, aviador de Belém veementemente pediram sua parte no bolo. Se a borracha era produzida de maneira anacrônica, o milho, o açúcar e todos os outros produtos agrícolas também o eram. "Porque nos escolher para vítimas?" perguntou Samuel Beuchimol, economista de Manaus. Se os preços internos do Brasil tivessem que ser igualados aos do mercado mundial , porque não começar, sugeriu ele, pela indústria automobilista. [. . . I Insistindo na validade da Lei 5.227, os fabricantes de artefatos de borracha pediram que o Congresso "admitisse a extinção da extração silvestre" e autorizasse a implantação de mais fábricas de borracha sintética. Além disso, queriam que o preço governamental se baseasse no custo da borracha plantada, não da borracha extrativista.

Diante do exposto, em junho de 1968 foi aprovada a Lei de n. 5.459 para reger a política nacional de borracha.

De conformidade com a nova orientação, que no seu artigo $2^{\circ}$ da Lei 5.459 determinava que no caso das borrachas importadas seus preços seriam equiparados ao produto nacional, elevando substancialmente a TORMB, e a diferença creditada ao Fundo Especial da SUDHEVEA, a SUDHEVEA, por sua vez, criada pela Lei 5.227, de janeiro de 1967, foi implantada com o objetivo de contribuir para a constituição e movimentação de estoques de reserva, operando na compra e venda de borracha, bem como prestar assistência técnica e tecnológica aos produtos industriais e aos comerciantes de borracha.

No ano de 1968, a diferença entre os preços de borracha nacional e a importada permitiria à TORMB e, portanto à SUDHEVEA, acumular recursos da ordem de 8,1 a 9,4 milhões de dólares por ano (REGO, Op. Cit., p. 377).

Assim, os custos de produção da borracha de origem extrativa passavam a regular os preços de todos os elastômeros consumidores pela indústria. Dessa forma, subvertia-se o conteúdo da política já delineado no período juscelinista e instituída com toda nitidez após o golpe de 1964. Os preços da borracha brasileira passaram a ser reajustados acima do IGP, 
apesar de, em 1968, já representarem 2,5 vezes a cotação da borracha vegetal importada (ALVES PINTO, 1984. p. 138).

Por outro lado, foram destinados todos os recursos necessários à proteção da produção extrativa, especialmente para atender às demandas de financiamento. Posteriormente, no governo Médice foi instituído o Programa Especial de Assistência Financeira ao setor de borracha vegetal da Amazônia.

Por esse decreto, os recursos arrecadados da TORMB seriam utilizados para financiar a produção extrativa por meio do BASA, além de ampliar o estoque de reserva de borracha natural administrado pela SUDHEVEA.

Para o discurso oficial essas medidas objetivavam a superação da insuficiência da produção interna de borracha vegetal. Todavia, a "solução" existente não atendia aos interesses dos monopólios da indústria de artefatos, que manifestou-se hostilmente às novas diretrizes. Reivindicavam o retorno a política de equiparação de preços, a gradual extinção do extrativismo, a liberação das importações, sem obstáculos, e a ampliação da produção de borracha sintética. Não se cogitava de modernizar a produção vegetal com a implantação de seringais de cultivo.

Entrementes, a política gumífera pós 1968 passou a beneficiar os interesses envolvidos no extrativismo da Amazônia e desembocar no Programa de Incentivo à Produção de Borracha Vegetal - PROBOR (criado em 17 de julho de 1972, através do Decreto-Lei $\mathrm{n}^{\circ}$ 1.232), que mantinha o amparo à produção extrativista e incluía um subprograma de reabertura de seringais nativos.

Dessa forma, o PROBOR dava ênfase à racionalização da produção através dos seringais de cultivo. Destacamos, também, que as políticas anteriores haviam contemplado essa alternativa. No entanto, a dispersão das áreas de plantio e a precariedade da infraestrutura e da pesquisa não indicavam condições de exeqüibilidade. 
Nos anos de 1970 e 1971, realizaram-se esforços no sentido de uma solução para o abastecimento de borracha natural numa perspectiva nacional. E o GEPLASE (Grupo de Estudos para o Plantio de Seringueira), criado em 15 de outubro de 1969 pela Portaria E30/69, em seu relatório apresentou uma proposta de aumento da produção de borracha vegetal para eliminar os déficits que se prenunciavam, baseados na expansão da heveicultura, abrangendo contribuições paritárias da Amazônia, Bahia e Planalto Paulista.

Por outro lado, a SUDHEVEA, em 1971, apresentou o Plano Nacional de Borracha (PNB) fundamentado na produção racional, por meio da heveicultura, nas várias regiões potencialmente produtoras do País.

No entanto, essas tentativas pontuais, na verdade, representavam a resistência da indústria de artefatos de borracha à política protecionista em relação à borracha amazônica.

Portanto, a primeira metade da década de 1970 foi marcada pela elevação dos preços internacionais das matérias-primas, particularmente do petróleo. Esse fato criou uma expectativa de elevação explosiva dos preços da borracha sintética, tendência que vinha se agravando desde o início dos anos 70 (REGO, 2003, p. 380).

E, efetivamente, o preço da borracha sintética atingiu o percentual de 134,1\%, entre 1968 e 1973. Por sua vez, a dependência crescente de borracha sintética ameaçava os lucros da indústria de artefatos. Frente a esse fato, a saída seria aumentar o suprimento de borracha natural por meio da importação ou do incremento a produção interna.

Nos anos seguintes, conforme assinala Rego (2003, p. 381), o quadro se agrava a tal ponto que a produção da borracha natural, que supria 68\% do consumo, passa a abastecer apenas 32\% em 1974.

Como a tendência era de agravamento cada vez maior, o Estado propôs incentivar a produção interna da borracha vegetal através do PROBOR II (Resolução do CNB $n^{\circ}$ 33, de 1977) e do PROBOR III (Decreto de $n^{\circ}$ 85.929, de 23 de abril de 1981). Além de preconizar o 
plantio de 120.000 ha de seringueira, o PROBOR II pretendia recuperar 10.000 colocações de seringais nativos e a abertura de 5.000 novas colocações, entre 1978 e 1982, por meio de subprogramas voltados para os seringais nativos (REGO, 2003, p. 381-382).

No entanto, o resultado não é o esperado e em 1977, a produção de borracha representava apenas " $90 \%$ da obtida em 1970, enquanto o consumo crescia $94 \%$ no mesmo período"275.

Por sua vez, o PROBOR III estabelecia como meta o plantio de 250.000 ha de seringueiras e ampliava os estímulos aos seringais nativos, além da projeção de recuperação de mais de 5000 colocações de seringueira, criava-se um subprograma para financiamento e instalação de 500 mini-usinas de beneficiamento de borracha, voltados especificamente para os seringueiros ditos autônomos. Esse apoio direto ao seringueiro foi mais tarde ampliado com o fornecimento de alimentos e utensílios, a preços subsidiados, por meio de um convênio entre a SUDHEVEA e a COBAL (Companhia Brasileira de Alimentos) e a ações nos setores de educação e saúde, mediante convênio da SUDHEVEA com governos estaduais (REGO, 2003, p. 382).

Todavia, os resultados esperados não ocorrem como previstos pela política governamental fazendo com que, no caso do Acre, nos anos 70 e 80 ocorressem profundas transformações sociais, culturais e econômicas.

No campo cultural teve-se a fundação da Universidade do Acre, que iniciou suas atividades com os cursos de Direito (1964) e Economia (1968), e os de licenciatura curta para atender as demandas dos ensino de $1^{\circ}$ e $2^{\circ}$ graus, sendo estes gradativamente transformados em licenciatura plena.

Em 1974, a Universidade do Acre federalizou-se, passando a denominar-se Fundação Universidade Federal do Acre. Por outro lado, na esfera do governo do Estado, foi criada a

${ }^{275}$ REG0, Op. Cit. p. 382, 
Fundação Cultural, que, frente a amplitude de suas atividades, passou a intitular-se Fundação de Recursos Humanos, da Cultura e do Desporto.

De um lado, a criação da Universidade possibilitando qualificar recursos da região para atender as necessidades do setor público nos mais diversos campos, sobretudo quanto à capacitação de professores para os ensinos fundamental e médio, além de viabilizar aos docentes que a integravam a possibilidade de participarem de cursos de pós-graduação em nível de mestrado e doutorado em outras regiões do País e, do outro, a Fundação Cultural, atual Fundação Elias Mansour, oportunizando a realização de eventos culturais, de acervos básicos de artes e literatura, festivais de música e cinema, publicações de obras, acrescentando-se ainda que a televisão chegou ao Acre na década de 70, quando o empresário de ascendência libanesa. Tufic Assmar criou a TV Acre, retransmissora da programação da Globo, além da popularização do uso do rádio de pilha no interior do Estado.

No que concerne a efervescência cultural vivida em Rio Branco nos anos 70, merece destaque a atuação de Elias Mansour, jovem idealista, descendente de libanês e integrante de uma família tradicional de Brasiléia, que posteriormente radicou-se na capital acreana, o qual teve a oportunidade de estudar no Rio de Janeiro, militar no movimento estudantil, inclusive na UNE, sendo, em função de suas idéias e prática política, cassado após 64 por dez anos. O jovem Elias, ao retornar ao Acre no contexto da repressão política, tornou-se para a juventude acreana, notadamente rio-branquense, um líder, aquele que iria aglutinar em torno de si rapazes e moças sedentos do saber, ansiosos por uma perspectiva de vida diferente da vivida até então por eles e sobretudo pelos seus pais.

Não era um bastião de resistência a Revolução. Era um projeto que visava acomodar essa geração que estava sem nada fazer. Era uma resistência pacífica, sem armas. Era o jovem conhecer os seus direitos e deveres. $\mathrm{O}$ que era capaz de produzir. [. . .] Quando acordaram o Elias já era uma grande liderança através da aliança com várias pessoas da comunidade, pessoas idosas inclusive. Professores da Universidade como o prof ${ }^{\circ}$. Tê, o prof. Tinôco, D. Diná, D. Iolanda, meu pai que foi quem doou a casa. Era um monte de jovens que ficavam lá estudando, ajudando, plantando, 
pintando. . . E a coisa cresceu, as pessoas iam lá gratuitamente se alistar, vamos dizer assim. E assim começou o Juventus [Clube Recreativo], lá tinha sempre encontros, reuniões, palestras, filmoteca, teatro de bonecos, essa coisa toda típica das nossas raízes nordestinas e nesse bojo se fez um grupo que tocou, que encheu de alegria essa cidade. Outros saíram para estudar música em função dessa força que o Elias deu. . . ${ }^{276}$.

Homem de esquerda, convicto de suas posições frente ao quadro político nacional, Elias Mansour buscou, através do Movimento Cultural fez do Juventus, da Fundação Cultural e da Secretaria de Educação e Cultura, sobretudo dos dois primeiros, espaços formadores de lideranças, dinamizadores da cultura, oportunizando a descoberta e valorização dos talentos artísticos e literários dos jovens. A sua gestão à frente da Fundação Cultural propiciou o surgimento de grupos de teatro, de cinema e festivais estudantis de música. A arte e a cultura como resistência política e projeto de vida. . .

O Juventus possibilitou que se pensasse um projeto maior para este Estado. Projeto de vida. Elias era a grande liderança e já começava a incomodar. Só que havia muito respeito por nossa família e por isto ele era poupado de coisas mais violentas, mas sofria porque as pessoas discriminavam muito. Ele não podia trabalhar em lugar nenhum. Mas, ele já tinha uma comunidade com certo peso apoiando - pessoas, pais, professores porque ele era prof. do META [Colégio particular], que na época tinha outro nome. A história que chegava aqui era que ele tinha sido cassado, falavam do julgamento dele, que ele não tinha identidade, não podia votar, nem ser votado. Aí um dia o Dr. Sobral Pinto representou ele no julgamento. Havia os que eram contra, doidos que ele fosse condenado e os que torciam a favor. Ele foi absolvido por unanimidade e mandaram queimar o processo. Já havia outros ares, já se respirava um ar mais leve; já havia passado aquele período doido de 68, 69, 70 de matar as pessoas, de torturar. Era muito perigoso, tinha as organizações paramilitares, e eles estavam aí prá fazer o que mandassem. Mas era impressionante, você olhava para o Elias, seu semblante, e você não via nem o olho dele tremer. Ele não tinha medo de nada, absolutamente nada. . . ${ }^{277}$.

Embora a conjuntura nacional estivesse marcada pelo autoritarismo político, sob a coordenação de Elias Mansour, várias lideranças começaram a surgir como parte da resistência política. Nesse caso, destaca-se o papel da Universidade e da Igreja, com suas

\footnotetext{
${ }^{276}$ MANSOUR, Francisco Eduardo Pinheiro: depoimento [15 de julho de 1996]. Entrevistadora: Maria José Bezerra. Rio Branco.

${ }^{277}$ Ibid.
} 
Comunidades Eclesiais de Base, na formação de jovens que se tornarão intelectuais orgânicos e se destacarão nas décadas de 80 e 90 nos mais diversos setores públicos.

Eu acho que o que matou o Elias foi essa coisa de legitimar um governo que não era legítimo, porque era escolhido. O meu cunhado [Joaquim Macedo, ex governador do Acre pós 64], era um homem de bem, extremamente generoso, mas ele foi escolhido e se assessorou dos cunhados. E foi Elias Mansour quem liderou o governo do Macedo. Ele tinha esse poder. Ele começou a viabilizar no governo aquilo que sonhava e que antes não tinha como fazer. A Fundação era uma coisa no papel, criada pelo Mesquita, mas apenas uma fundação. Com o Elias é que a Fundação cresceu, ampliou-se, mudou de nome envolveu vários setores, pessoas como o Mário Lima, o Valdir, o João, o Lauro Julião essa gente toda. . . Esse projeto que está aí, que Jorge Viana utilizou, já tinha muita coisa, não era inventado, não era um projeto encomendado por quem não tinha nada com esse Estado. E tinha gente lá em Brasília que tinha foto da gente na primeira manifestação dos professores pois a gente cedeu o aparelho de som para eles falarem na frente do Palácio do governo e disseram para o ministro que a gente estava comunizando o Estado. Teve a Associação dos professores, inclusive o Elias foi presidente. E ela foi 0 embrião do SINTEACRE, da atualidade ${ }^{278}$.

Os fins da década de 1970 foram marcados nacionalmente pela organização da sociedade civil brasileira, e no Acre o processo não foi diferente. A resistência política à ditadura implicou não só o movimento das Diretas-Já e da Anistia, como também na organização dos professores das redes pública e privada, nas discussões dos currículos, das condições de trabalho e salariais e, sobretudo, nas filosofias educacionais para se contrapor a um ensino abstrato, descolado da realidads política e social vigente, durante o regime militar.

A gente envolvia a Comissão de Terra, a Igreja, o INCRA, Imprensa. A OAB-AC fez um trabalho de peso, negociando com professores, com posseiros. Era uma coisa muito forte. E aí a Fundação ficou mais abrangente, passou a estimular grupos teatrais, de produtores culturais, de músicos. Se estabeleceu um elo entre a comunidade e o governo. [. . . ] Esse bairro aí, o João Eduardo foi o Elias que organizou as invasões. As primeiras organizações de bairro saíram da cabeça do Elias. Este estimulava as pessoas, dava a elas livre trânsito no Palácio. João Eduardo [líder de posseiros] e Dom Moacir [Bispo da Diocese de Rio Branco] eram muito ligados a ele $[\ldots]^{279}$.

${ }^{278}$ Ibid.

${ }^{279}$ Ibid. 
Num contexto educacional marcado pelas concepções tradicional e tecnicista, Elias Mansour, enquanto educador, caracterizou-se por uma prática educativa conscientizadora e libertadora calcada na pedagogia de Paulo Freire adaptada ao contexto amazônico.

Ele dirigiu o CERB [Colégio de $2^{\circ}$ grau da rede pública]. Ele coordenou o projeto de alfabetização de adultos utilizando o método Paulo Freire. Eu trabalhei com ele. Fizemos um concurso nacional. Fui trabalhar, quando estava no RJ com este método na baixada fluminense. Eu conheço muito bem o método. Fui monitor e depois supervisor. O Elias foi o coordenador geral desse projeto. Este projeto incomodou muito. Ele trouxe este projeto para o Acre e vestiu com outra roupagem. Ele regionalizou o projeto. Tinha coisas que não tinham muito sentido, ele fez adaptações. [. . .] Naquela época, a Secretaria de Educação era também Secretaria de Educação e Cultura e não conflitava com a Fundação Cultural, pelo menos na época dele. A Secretaria trabalhava mais com o projeto nacional, já na Fundação a gente fazia o projeto e captava recursos [... . $]^{280}$.

No aspecto social, foi uma fase marcada pelo crescimento desordenado das cidades acreanas, principalmente Rio Branco, que por ser o principal centro de desenvolvimento do Estado tornou-se pólo de atração dos seringueiros e suas famílias expropriados de suas posses devido ao processo de venda dos seringais acreanos para empresários do Centro-Sul, provocando a transferência de 5 milhões de hectares, o que representava basicamente um terço da superfície total do Acre, embora haja controvérsia a respeito da extensão das terras transferidas aos empresários do Centro-Sul.

As informações oficiais contidas nos cadastros do INCRA, segundo se pode deduzir de informações não oficiais que circulam localmente, não são capazes de relacionar todas as áreas efetivamente já em poder dos grandes grupos e, principalmente, de distinguir os proprietários reais de simples testa de ferro. [...] As primeiras informações sobre o assunto falavam em 5 milhões de hectares, o que representa um terço da superfície total do Acre. Posteriormente, outras fontes chegavam a avaliar em 8 milhões de hectares, enquanto que relatório do INCRA, citado pelo jornal "Varadouro" aparentemente baseado em dados do Recadastramento de 1978, registrava 218 latifúndios por dimensão, com área total de 5,8 milhões de hectares, e 3.102 latifúndios por exploração, abrangendo 6,4 milhões de hectares. Assim $80 \%$ das terras acreanas estariam nas mãos de grandes proprietários, mas isso não chega a elucidar a questão, pois é

${ }^{280}$ Ibid. 
preciso estabelecer quanto dessa proporção efetivamente pertence aos grupos do centro-sul ${ }^{281}$.

Dessa forma, o êxodo rural gerou a formação de bairros periféricos no entorno de Rio Branco, desprovidos dos equipamentos urbanos básicos essenciais aos "ocupantes” dessas áreas.

Por outro lado, esses espaços urbanos, que atualmente perfazem um total de aproximadamente 180 bairros, segundo dados não oficiais da Prefeitura Municipal de Rio Branco, na medida que a grande maioria desses bairros não está cadastrada, passaram a marcar a paisagem da cidade pelas problemáticas sociais que apresentam, pois neles a exclusão social evidencia a sua face mais cruel.

Outro aspecto que fez com que o Acre figurasse na imprensa nacional e internacional foram os conflitos pela posse de terra frente ao confronto entre os "paulistas" e os seringueiros-posseiros, os quais culminam em atos de violência os mais diversos, gerando, inclusive, assassinatos de lideranças do movimento sindical rural, que se organizou no contexto desses conflitos.

As mudanças de mentalidade, o acesso à informação, inclusive a possibilidade de discussões fundamentadas em autores de vertente marxista e neomarxistas no âmbito da Universidade e fora dela, a atuação da imprensa alternativa, através do jornal “O Varadouro”, similar do “Pasquim”, a resistência organizada por setores de esquerda da OAB-AC, da Igreja e políticos, a sindicalização dos trabalhadores rurais e o movimento ecológico, notabilizando nacional e internacionalmente Chico Mendes, são fatores que, conjugados, contribuíram para a vitória da oposição no pleito eleitoral para o governo do Estado em 1982, garantindo a vitória de Nabor Júnior (PMDB).

É a partir dessas mudanças que nos interessa discutir não o governo da floresta, mas a floresta governa.

${ }^{281}$ OLIVEIRA, Luiz Antônio Pinto de. O sertanejo, o brabo e o posseiro (os cem anos de andanças da população acreana) Belo Horizonte: UFMG, 1982. p. 52. 


\section{1 - O grito da floresta}

A alma do governo é a questão ambiental. A questão ambiental no Acre é muito importante porque é a questão da vida dessa cultura e dessa civilização do Ocidente da Amazônia”.

Gilberto Siqueira

Levando em consideração o que abordamos nos capítulos anteriores, mormente no que se refere à anexação das terras do atual Acre ao Brasil, na primeira década do século XX, nos interessa nesta parte do trabalho discorrer acerca da construção do imaginário da Amazônia como selva e depois como floresta e de que forma a natureza tem marcado não apenas a terra acreana, mas, sobretudo, a alma dos acreanos

A Amazônia brasileira - e o Acre está inserido neste contexto - é vista a partir do século XIX como selva e este olhar era não só compartilhado pelas elites nacionais, o Estado brasileiro, mas, também, pelos literatos da região e cronistas do “descobrimento” dessa parte do Brasil, inclusive pelos viajantes estrangeiros que fizeram suas incursões na região através das expedições científicas. Nesse sentido, merece menção a expressão de Euclides da Cunha “A Amazônia selvagem sempre teve o dom de impressionar a civilização distante”.

O cenário verdejante da Amazônia é representado por sua grandeza e mistério. A floresta é tida como um local exuberante, desenhado por caudalosos rios, habitado por índios selvagens e monstros devoradores. É um espaço onde os perigos abundam. Rica, misteriosa, exótica, enigmática, perigosa... são expressões que a representam, segundo o olhar civilizador.

E essas imagens cristalizaram e instituíram uma definição da região, a partir da visão do outro.

Os estigmas que recaíam sobre a região, a partir dos valores dominantes do outro, do “civilizado”, acentuavam como marcas determinantes da região o isolamento, a grandeza e os 
recursos naturais, as quais irão alicerçar a visão dicotômica, dualista, da Amazônia como céu e inferno, luz e treva.

A Amazônia, por essa lógica instituída a partir de conceitos vindos de fora, dos centros culturais do país ou dos países estrangeiros, tem a sua identidade constituída.

A natureza e o homem passam a caracterizar os discursos construídos sobre a Amazônia.

A invenção da Amazônia a partir da versão inaugural descrita acima marcou a inserção desta nos contextos nacional e internacional.

E o Acre emerge nesse universo por sua importância econômica devido ao extrativismo da borracha.

No entanto, os que vinham para a Amazônia Sul Ocidental (O Acre) conservavam na memória a lembrança da terra natal e acalentavam o desejo de retornar a ela.

Desterrados de suas regiões de origens, os seringueiros mergulhados no "holocausto" da borracha aprenderam dolorosamente a dialogar com a natureza, como parte integrante do cosmo amazônico.

Nominaram e dominaram coisas, plantas e bichos que compunham o seu habitat e nessa relação dialógica com um mundo natural, foram tornando conhecido o desconhecido. Gradativamente, a selva foi domada pelo homem, mas imprimiu neste o seu ethos. Céu e inferno não se opunham, completavam-se.

Para os seringalistas que vieram nos primeiros anos de ocupação econômica do Acre, a dualidade de luz e treva também marcava a concepção destes acerca da Amazônia.

A perspectiva da maioria era ganhar dinheiro com a borracha, mas investir noutras regiões como Belém, Manaus e Rio de Janeiro, na medida que era desta última que chegavam as novidades. O moderno vinha de fora pelo rio. 
Vivia-se fisicamente no Acre, porém, os desejos, os sonhos estavam além-fronteira. . . Os mais abastados mandavam buscar gêneros alimentícios, roupas, sapatos, louças e até telhas de outras regiões do Brasil ou do exterior e também sentiam-se desterrados e, entre estes, os mais esclarecidos enviavam os filhos, sobretudo os homens, para estudar fora - Belém, Manaus, Nordeste e Rio de Janeiro, preferencialmente.

Com o passar do tempo, a história da “civilização acreana” foi sendo escrita, mas o glamour dos tempos áureos da borracha foi esmaecendo a medida que a economia gumífera entrava em crise. E a selva sendo “civilizada” transformou-se em floresta.

Importante também considerar que a humanização da selva transformando-a em floresta teve um custo social para os nativos da região, os povos tradicionais - índios, seringueiros e ribeirinhos.

E, dando curso ao processo de invenção da floresta, vieram os novos tempos trazidos pela expansão da fronteira econômica.

Esse conceito nos parece mais adequado para estudar o processo de mudança que ocorreu no Acre a partir da década de 1970, por não se tratar apenas de um movimento de uma área geográfica mais ampla, densamente ocupada, intensificamente para outra menos explorada e também menos ocupada.

A expansão da fronteira econômica inaugurou uma outra invenção do Acre que fundamentou-se no movimento das relações de produção capitalista que caracterizavam as áreas mais desenvolvidas do Brasil, como São Paulo, o Centro-Sul, para outras áreas onde a economia não era especificamente capitalista.

Até então, a base econômica do Acre era caracterizada pela organização extrativista da produção baseada no seringal tradicional, ainda pré-capitalista.

Embora os movimentos de pessoas e capital para a Amazônia sejam anteriores aos governos militares, foi inegavelmente após 64, com os governos militares, que a expansão 
para a Amazônia assumiu um aspecto grandioso, inclusive para atender os objetivos do Estado brasileiro, caracterizado pela ditadura e pela formulação da geo-política, e ainda, a ideologia da segurança nacional.

Esse discurso, construído pelos ideólogos do Estado ditatorial, escudado pelos intelectuais da Escola Superior de Guerra, tendo como expressão máxima o general Golbery Silva, colocava o Brasil no contexto da geopolítica mundial como uma região estratégica frente à reduzida distância deste para a Ásia e África, lembrando ainda que, no período da Segunda Guerra Mundial, o Brasil foi estrategicamente relevante para a dominação do Atlântico pelos aliados e então nessa ótica a geopolítica considerava este fato um “trunfo", um fator fundamental para que o Brasil, mesmo inserido no contexto da hegemonia norteamericana no mundo, tivesse um papel de destaque como "grande potência” e nesse aspecto, a Amazônia assumia um grande destaque pelo seu tamanho, seu território, sendo o contexto interno visto como uma "guerra” permanente interna, uma "guerra civil” permanente cujo inimigo era caracterizado pelos movimentos populares de esquerda, significando, ainda, a vinculação desses movimentos com o comunismo internacional, com a União Soviética.

Este raciocínio levava à conclusão de que se precisava combater o inimigo interno diante das conexões deste com a União Soviética e Cuba, e a Amazônia estava imbricada nesse processo por vários fatores. Em primeiro lugar, havia no Brasil os grupos de esquerda que resistiam à ditadura, inclusive os armados, que integravam a guerrilha urbana e cujo projeto maior era criar as bases para lançar a guerrilha rural, a revolução no campo - neste caso podemos citar a Guerrilha do Araguaia -, e a Amazônia passa a ser vista como território potencial para a organização da guerrilha no campo, agravada ainda pelo fato de a Amazônia estar cercada de países andinos, que na época tinham os seus movimentos revolucionários. Neste arco de conexões, a doutrina da segurança nacional passa a ser o fundamento da geopolítica da Amazônia. 
Assim, nesse contexto a Amazônia precisava ser ocupada militarmente e, principalmente, pelo capital, para se constituir numa barreira à resistência revolucionária.

Nesse “tabuleiro de xadrez” da geopolítica, com a ocupação econômica da Amazônia, a população seria integrada social e politicamente, constituindo-se um "bloco" contra a iniciativa revolucionária, dessa forma se legitimava a expansão capitalista na região.

Sendo assim, nessa época do Brasil grande, do “Prá Frente Brasil”, as determinâncias do processo histórico não foram exclusivamente econômicas e sociais, mas, também, políticas, geopolíticas e culturais

Portanto, o deslocamento do capital para uma área “vazia”, não de gente, mas de capital, foi implementado tendo por base o discurso ideológico "precisamos ocupar a Amazônia”.

Outro aspecto a considerar é que a época da ditadura foi caracterizada pela euforia econômica, conceituada pelos economistas, sobretudo os de vertente marxista de “milagre econômico”. Como desdobramento destas conjuntura, ocorreu a produção de grandes lucros por empresas do Centro-Sul e do Sudeste, levando a um excedente de capital que necessitava de novos canais de investimentos, e a Amazônia passa a ser um desses canais privilegiado para investimentos por possuir terras e, sobretudo, porque teria várias formas de valorização, sendo uma delas a valorização pela renda, que por sua vez depende de vários fatores como a localização, a infra-estrutura. Nesse aspecto se configuram os investimentos realizados pelos governos militares na Amazônia.

Outro fator que atribuía valor à terra eram os subsídios governamentais, sendo este um instrumento para captar capital excedente e lucro considerável, como assinala, em entrevista, o economista José Fernandes Rego.

Se você tem uma inflação como nós tínhamos na época em torno de $40 \%$ e os programas como o PROTERRA e POLO AMAZONIA ofereciam financiamento a $7 \%, 10 \%$ ao ano, então você tinha aí um ganho extraordinário. Estas eram formas de ganhos econômicos pela simples cotação da terra. Então o capital especulativo se estabeleceu na Amazônia, 
se instalou no Acre, comprando terra nos primeiros cinco anos. Os proprietários fundiários vieram do Centro-Oeste, do Sul e Sudeste e compraram um terço das terras do Acre e boa parte dessa terra passou a ser objeto de especulação [... . $]^{282}$.

Portanto, a possibilidade de vir para a Amazônia significava grandes lucros para os que buscavam um canal de investimento a mais, e essa prática não ocorreu apenas na compra de terras, mas, também, nos empreendimentos minerais, minero-metalúrgicos, devido aos volumosos incentivos. E todas essas ações significavam ganho de capital.

Outro aspecto que merece ser mencionado de âmbito social foi a luta social, o enfrentamento de classe. E, nesse sentido, ressaltamos que durante o regime militar, em pleno "milagre econômico", a grande burguesia nacional se fortaleceu consideravelmente. Seu poder era incontrolável, era quase insuperável e o incentivos fiscais eram uma demonstração concreta do seu poder, na medida que esta exercia um forte impacto sob o Estado, levando, inclusive, à imbricação entre Estado e capital, fazendo com que alguns estudiosos de forma simplista identificassem Estado e capital, por considerar que o Estado tinha se tornado um objeto do capital ou era privatizado por este.

Logo, em virtude de sua posição favorável, a grande burguesia contribuiu, sobremaneira, para a implementação dos mecanismos de incentivos fiscais da SUDAM, BASA, através de programas como o POLOAMAZÔNIA e o PROTERRA entre outros, além das grandes concessões de grandes áreas para a mineração, entre as facilidades que existiram.

Para explicitar melhor nossa abordagem, é mister acentuarmos que a expansão da fronteira econômica se desenvolveu por meio de dois grandes fluxos. E o seu caráter capitalista se apresenta no fato de que não existe capital sem trabalho, daí os dois fluxos serem constituídos pelo capital e os trabalhadores, e como parte da "grande migração", os nordestinos vindos diretamente ou pela mediação do Centro-Sul foram para as lavouras do sul

${ }^{282}$ REGO, José Fernandes do: depoimento: [30 de julho de 2004]. Entrevistadora: Maria José Bezerra, Rio Branco. 
fortalecendo o desenvolvimento do capitalismo na agricultura das regiões do Centro-Sul e Sul.

E, como parte desse ato de proceder, ocorreu a modernização do processo produtivo, além da existência de um grande setor populacional, inclusive devido à presença do latifúndio no Nordeste.

Dessa forma, a combinação desses elementos contribuiu para os fluxos de trabalhadores para a Amazônia, além do quê, a fronteira comporta diversidades e os dois fluxos podem vir juntos e se superporem, como aconteceu no sul do Pará, fazendo com que o fluxo enorme de migração e capital resultasse no conflito social no campo.

Há também o caso de Rondônia, que apresenta outra peculiaridade: na medida que veio primeiro o fluxo de trabalhadores, sem o capital, posteriormente é que este se rebateu sob o fluxo de trabalhadores que já integravam processo de colonização, gerando outro tipo de conflito.

\section{E o Acre?}

No caso do Acre, não ocorreu um fluxo de trabalhadores forte para a região, todavia este possuía uma economia extrativista ainda funcionando com uma população extrativista ocupando o seringal. E, então, o fluxo de capital se rebateu sob a estrutura da sociedade extrativista tradicional gerando conflitos violentos frente à desagregação que provocou no extrativismo tradicional, que, por sua vez, já vinha atravessando um processo falimentar, que acelerou-se gerando conflitos pela terra em grandes proporções registrados pela imprensa no Brasil e exterior, e objeto de estudo de economistas, sociólogos e historiadores da UFAC e de outras instituições, a saber: Adalberto Ferreira da Silva, Elio Garcia Duarte, Sandra Tereza Cadioli Basílio e Pedro Vicente da Costa Sobrinho nos respectivos trabalhos "Raízes da Ocupação Recentes das Terras no Acre”, “Conflito pela Terra no Acre”, “A Igreja e a luta pela terra no Acre” e “Capital e Trabalho na Amazônia”, além da consistente pesquisa 
desenvolvida por José Fernandes do Rego, no imprescindível trabalho “Estado e Políticas Públicas - a reocupação da Amazônia durante o regime militar”.

Importante considerarmos ainda que os jornais locais, especialmente o Varadouro e outros nacionais da chamada "grande imprensa”, como “Jornal do Brasil”, "Folha de S. Paulo”, “Estado de S. Paulo” e “O Globo”, citando os de maior expressão, constituem fontes de pesquisa de grande valor no que se refere à expropriação dos seringueiros de suas posses, sobretudo no período de 1972 - 74, considerada pela literatura produzida pelo tema o de maior pico.

Gente indo e gente vindo, gente rica e gente pobre, investidores sérios, pecuaristas, fazendeiros do sul e homens de negócio. Profissionais liberais, dentistas, médicos, farmacêuticos, advogados que se reúnem em grupos para tentar o caminho da libertação financeira. Aventureiros que nada possuem além da boa aparência do terno de casemira inglesa comprado a prazo. Simples lavradores que vendiam tudo, tomavam um ônibus, levando mulher e filho na busca de nova vida. Comerciantes árabes, italianos, espanhóis, brasileiros, judeus. É um mosaico de tipos que se encontra a cada passo nas cidades do Acre, na grande luta pela compra da terra. Vá mais leve dinheiro vivo. Em nota. Se tiver que voltar para fechar o negócio, o preço já será mais alto. ${ }^{283}$

A dramaticidade da situação social vivida pelos seringueiros e suas famílias ocasionada pelas transformações que o Acre vinha passando é registrada em toda a pungência pela imprensa nacional.

Estanislau Siqueira de Souza, um Pernambuco de 60 anos que há 30 vive no Acre, foi escorraçado da sua colocação no seringal Belo Jardim. Só teve tempo de apanhar as roupas e fugir para Rio Branco, onde vive de biscates, depois de mandar a família para Pernambuco. Maria Cassiana dos Santos, viúva, 90 anos, que há 58 anos morava no seringal Belo Jardim, também foi expulsa com seus nove filhos, 50 netos e 38 bisnetos. ${ }^{284}$

\footnotetext{
${ }^{283}$ TAMER, Alberto. O Acre foi lembrado e agora enfrenta a invasão. O Estado de São Paulo. São Paulo, 27 de agosto de 1972, p. 26. In: COSTA SOBRINHO, Op. Cit. p. 55.

${ }^{284}$ FONSECA, Ribamar. Acre muda base econômica e causa tensão nos seringais. Jornal do Brasil. Rio de Janeiro. 26 de junho de 1974, p. 7. In: COSTA SOBRINHO, Op. Cit. p. 58.
} 
E, neste contexto, é importante assinalarmos que o conceito de propriedade capitalista difere do conceito de propriedade da economia extrativista tradicional, que apresenta como particularidade, a visão de que para o seringalista, o que importava não era a propriedade exclusiva da terra.

No seringal, a propriedade era quase "plural”, múltipla, só que hierarquizada. Para o seringalista, não importava que o seringueiro tivesse a posse de sua colocação e o direito de neste permanecer o tempo que desejasse. Era um tipo de propriedade diferente, típica da reprodução do extrativismo. No capitalismo, a propriedade era diferente, tinha que ser exclusiva, a terra transforma-se em mercadoria. Nesse sentido, precisa estar livre para ser negociada. Daí porque o conflito entre o patrão-seringalista e o seringueiro era diferente, como já abordamos, não envolvia a propriedade da terra, não sendo esta questão central em relação aos conflitos que ocorreram, os quais eram de outra ordem. Os conflitos ocorreram por outro tipo de apropriação a do valor que o seringueiro produzia e não pela propriedade da terra.

Portanto, a vinda dos "paulistas" para o Acre gerou pressões de toda ordem para que o seringueiro deixasse o seringal. O extrativismo entrou na sua fase mais aguda, embora, importante destacar mais uma vez, a crise deste era secular devido, desde 1912, à produção de borracha do Sudeste Asiático ter "desbancado" o extrativismo brasileiro no mercado internacional e nos períodos subseqüentes, exceto no surto da Segunda Guerra Mundial, quando a economia gumífera teve um alento episódico, esta agudizou-se sendo substituída por uma economia nova, a economia agrária.

No Acre, a pressão exercida pelos compradores de terra denominados genericamente de "paulistas", ao promoverem as chamadas limpezas de áreas, muitas vezes até pelo desforço imediato tem atirado nos arrabaldes de cidades e vilas numerosas famílias, a maioria constituída de seringueiros pioneiros e tradicionais, que por várias dezenas de anos ocupavam tais terras, de onde tiravam o sustento. Sem dúvida alguma, além da evasão gerada pela expulsão do homem de seu "habitat" 
costumeiro, com prejuízos para a economia básica da região, marginaliza-o dentro de uma nova estrutura que não apresenta suporte para recebe-lo [ . . .] Até o início deste ano, o INCRA de Rio Branco já tinha cadastrado duas mil famílias de seringueiros, expulsas dos seringais pelos novos donos das terras. Outras fontes da capital, entretanto, garantem que esse total atinge a, pelo menos 10 mil famílias $[. .]^{285}$.

E a luta que se desenvolveu no Acre não foi apenas econômica, mas, também, social, ideológica, cultural. A floresta se insurgiu através dos seus atores sociais. A sua negação implicou a resistência, a luta dos seringueiros contra os fazendeiros, em decorrência da expansão da pecuária de corte ou ainda contra os especuladores de terra. A luta caracterizada pelas divergências econômicas, fundamentada também numa atividade que passava a ocupar espaço no mercado, na economia, apresentava também conotações ideológicas, culturais.

Por que cultural?

Na realidade, o que estava em jogo era o confronto de duas culturas. A cultura agrarista que remonta ao período da colonização do Brasil pelos portugueses, cujo discurso era a cristianização dos povos pagãos, dos gentios e, posteriormente, o da vocação agrária brasileira.

Interessante assinalar que no processo civilizatório nos países da Europa, os industrializados, o projeto da civilização coincidiu com a agricultura. Tal fato também ocorreu no Brasil, ensejando a criação da teoria dos ciclos econômicos pela historiografia brasileira clássica, a qual tem sofrido críticas por não comportar outras modalidades de atividades econômicas e de relações de trabalho não escravistas.

Outro aspecto a considerar é o caráter endêmico que a colonização das terras brasileiras assumiu, na medida que estas eram vistas como um eldorado, um paraíso - aliás,

${ }^{285}$ O Globo. Amazônia, seus programas. .. Acre: problema com a especulação da terra. Rio de Janeiro. 21 de maio de 1975. Panorama Econômico, p. 234-238. In: COSTA SOBRINHO, Op. Cit. p. 63. 
esse aspecto foi magistralmente abordado por Sérgio Buarque de Holanda na obra “A visão do paraíso”, cuja análise corrobora o ideal de estabelecimento de uma civilização cristã na América que se coadunava com o cultivo da terra.

Na Amazônia, o processo foi diferente e apesar do extrativismo das “drogas do sertão” ter gerado ganhos de capital, se constituiu uma atividade episódica, o que os colonizadores almejavam era a implantação da agricultura que possibilitaria um ganho econômico, cujo valor se reproduziria.

Dessa forma, o extrativismo era visto como atraso, de forma negativa. Civilizar é domar a terra e o homem e desenvolver a agricutura.

E esse imaginário cultural presente nos primórdios da colonização impregnou o desenvolvimento brasileiro e a cultura da burguesia agrária e da industrial, favorecendo a constituição de uma cultura agrarista, cujo imaginário preconiza que extrativismo é atraso e agricultura é moderno e que o desenvolvimento das regiões interiores do Brasil deve ser realizado através da agropecuária.

A esse respeito, em entrevista, o economista José Fernandes do Rego, atual assessor de Departamento de Produção do governo do Estado do Acre, destacou que há uma frase cunhada pelos colonizadores internos segundo a qual, para desenvolver é necessário fazer avançar a terra para a pata do boi, o que implica assinalar a conotação negativa que tem o extrativismo.

Supor que extrativismo se constitui numa atividade produtiva que tem uma forma social de produção marcada pelo atraso é, num certo sentido, considerar que a ciência é incapaz de gerar conhecimento para melhorar o processo extrativista, o que não procede frente aos avanços da ciência e da tecnologia a esse respeito.

Importante também assinalarmos que, como parte desse processo de expansão de fronteira econômica no Acre, os atores sociais que historicamente vêm interagindo com o 
mundo natural da floresta (índios, seringueiros, trabalhadores rurais), os quais tiveram suas presenças “silenciadas" ao longo desse processo, inclusive pela produção histórica tradicional da Amazônia, na medida que, foi a partir da década de 1970, que começaram a surgir trabalhos mormente monografias, dissertações e teses de discentes e docentes da UFAC e de outras instituições locais, nacionais e internacionais, que os colocam na cena histórica do Acre. Estes "povos da floresta” se insurgiram de forma individual ou organizada, no silêncio ou de forma ruidosa, contra a “morte” da floresta. Lutar pela floresta era lutar pela própria sobrevivência. A floresta agonizava, porém, ainda estava viva o suficiente para lutar.

Cabe-nos, então, ressaltar que a metáfora “a floresta governa” é explicitada historicamente no fato de que a constituição do Acre, enquanto espaço social, econômico, político e cultural, teve como alicerce o extrativismo da borracha, vinculado à economia capitalista internacional.

Nesse sentido, a seringueira não se constitui apenas na árvore de onde se extraía o látex, matéria-prima da borracha, mas, mefatoricamente, se constitui a árvore-mãe dos acreanos, na medida que a sociedade extrativista teve a sua origem nela.

Dessa forma, a seringueira vem desde os primórdios do Acre sendo a fonte da vida, em suas várias dimensões, para os atores sociais presentes na cena histórica acreana. Portanto, a “floresta governa” o processo histórico acreano.

Importante considerarmos que na sua agonia, a "floresta” buscou aliados e entre estes, notabilizou-se a ação da Igreja Católica, que desde 1963 começara a se preocupar com a organização do movimento sindical dos trabalhadores no Acre. Embora suas ações iniciais tenham sido tímidas, o fato é que a orientação do Bispo Dom Giocondo Maria Grotti não se limitou à evangelização tradicional na cidade, às desobrigas no interior dos seringais e às obras assistenciais. 
A inserção da Igreja no movimento social tornou possível em 1965 a criação da Associação dos Pedreiros e Auxiliar de Pedreiros, transformada anos depois no Sindicato dos Trabalhadores da Indústria da Construção Civil de Rio Branco.

Em 1968, também por iniciativa da Igreja, foi criado o Grupo de Elevação Social e Cultural do Acre - GESCA, para constituir pólo de atração dos jovens com preocupações sociais.

No entanto, foi a partir de 1971, com as Comunidades Eclesiais de Base (CEBs) no Acre, que a Igreja Católica demarca o seu espaço no movimento popular.

A este respeito, Mourão afirma:

As CEBS no Acre, por conseguinte, não nasceram por iniciativa popular e a margem da Instituição Católica. Antes, elas são o resultado da intervenção direta de uma equipe no meio popular, via Instituição Católica, na medida em que toda a equipe mantinha vínculos formais com ela ${ }^{286}$.

Ainda nesse mesmo ano, a Igreja criou o informativo “Nós Irmãos”, por meio do qual divulgava a ação religiosa e pastoral da Prelazia, orientava as CEBs, constituindo-se em instrumento de integração e unificação do trabalho.

Esse informativo passou também a divulgar os conflitos de terra, denunciar a violência dos confrontos entre fazendeiros e posseiros e informar e orientar os trabalhadores quanto aos seus direitos.

Posicionando-se acerca dessa questão, Mourão enfatiza:

Revendo os arquivos do boletim “Nós Irmãos” pode-se observar que os principais temas de conjuntura nacional e local foram noticiados, há um relativo balanceamento entre os temas sociais e os temas próprios das CEBs e da problemática religiosa. Seu conteúdo básico procura criar uma consciência crítica e transformadora da sociedade, os temas religiosos são tratados numa linha “libertadora"287.

\footnotetext{
${ }^{286}$ MOURÃO, Nilson Moura Leite. A prática educativa das CEBs: popular e transformadora ou clerical e conservadora? São Paulo: PUC-SP, 1988. p. 125.

${ }^{287}$ Ibid. p. 154.
} 
E, com o agravamento da situação social gerando um clima de alta tensão no Acre, o conflito pela posse da terra passa a ser questão da ação política e social da Igreja, fazendo com que o Bispo Dom Moacir Grechi, sucessor de Dom Giocondo, assumisse institucionalmente o firme propósito de orientar os trabalhadores rurais quanto aos seus direitos, o que se processa, segundo Costa Sobrinho (1988, p. 163), com a divulgação do documento "Catecismo da Terra”, inicialmente distribuído pelo padre Paolino Baldassari na sua paróquia de Sena Madureira, sendo mais de 400 exemplares enviados aos seringais.

O que era o "Catecismo da Terra”? Era uma publicação que objetivava orientar os trabalhadores a como reagir ante a ameaça de expulsão de suas posses e fazia referência ao Estatuto da Terra, enfatizando, com toda cautela, a questão fundiária com base no aparato legal vigente.

Para que a Prelazia do Alto Acre e Purus assumisse uma posição única em relação à questão da terra, Dom Moacir Grechi procurou convencer todo o corpo eclesial diante do problema vivido.

Não teve tempo para uma escolha. A minha condição de Bispo me obrigava a conviver e sentir bem de perto os problemas da população, em sua grande maioria pobre e, especificamente, conviver com o homem da mata [seringueiro] e também com os camponeses. No meu íntimo porém por convicção possível mas até, dada minha missão de pastor necessária. [. .. .] Minha vinda para o Acre, o contato direto, especialmente nas nascentes das comunidades Eclesiais de Base, com o povo simples, pobre, injustiçado, a ajuda insubstituível de padres amigos e muito sensíveis aos problemas do povo, homens lúcidos, corajosos e extremamente evangélicos; a confiança a mim depositada pelas vítimas do problema da terra que começaram em 1973, a se agudizar. Neste campo, fatos bem concretos levaram-me a tomar uma posição: ou assumia a causa dos pobres ou negava minha missão e mesmo minha própria fé $[. . .]^{288}$.

Prosseguindo na sua tomada de posição em favor dos pobres, a Igreja Católica realizou o primeiro Encontro do Vicariato do Acre, em Xapuri, que reuniu os padres da Ordem dos Servos de Maria, contando com a presença de Dom Moacir Grechi e do padre Pacífico. Nesse

${ }^{288}$ SALEM, Helena (Coord.). A Igreja dos oprimidos. São Paulo: Brasil Debates, 1981, p. 123. In: COSTA SOBRINHO, Op. Cit. p. 164. 
encontro, foi elaborado um documento que orientava a ação dos agentes pastorais para dar enfrentamento à questão da terra, o qual foi assinado pelo Bispo Dom Moacir, o Provincial da Ordem dos Servos de Maria, padre Francisco Carmineo, e outros onze padres.

Em face da grave situação criada pelo problema das terras no Estado do Acre e em particular do Território desta Prelazia, a Igreja Acre-puruaense, não entrando no lado técnico deste problema, mas inspirada no Evangelho de Cristo faz questão de dar a esse respeito suas diretivas para todo o povo de Deus. A problemática das terras preocupa em especial os posseiros, colonos e seringueiros que vivem na maioria das vezes há vários anos no interior de nossos seringais e colônias sobre quem pesa a ameaça de deixarem suas posses sem perspectiva alguma de sobrevivência. [. . .] multiplicam os casos de posseiros, colonos e seringueiros que da maneira mais arbitrária e mesmo violenta vêm sendo expulsos de suas posses sem o menor respeito à dignidade da pessoa e mesmo às leis vigentes [. . . $]^{289}$.

Prossegue o aludido documento enfatizando as orientações da Igreja em relação aos posseiros, que em termos gerais visavam conscientizá-los quanto aos seus direitos segundo o INCRA, empreender ações junto aos órgãos competente quanto ao acesso a documentação dos trabalhadores, de conformidade com a legislação trabalhista, denunciar junto ao INCRA, ao $4^{\text {o }}$ Batalhão de Infantaria e Selva ( $4^{\mathrm{a}}$ Cia.), a Polícia Federal, a Polícia Militar e a Secretaria de Segurança Pública os atos de violência cometidos contra os trabalhadores e, ainda, propor ao governo do Estado do Acre e ao próprio INCRA a inserção dos trabalhadores expropriados nos projetos de colonização oficial (COSTA SOBRINHO, Op. Cit. p. 165).

No que se referia aos investidores, a orientação estava centrada nos seguintes pontos: esclarecê-los quanto à real situação das terras, no tocante aos títulos, conforme diretrizes do INCRA; evidenciar, junto ao governo do Acre, e aos investidores, que, sem alternativa de sobrevivência, só restava aos posseiros e seringueiros a marginalização; destacar, junto ao governo do Acre a situação das terras, a qual trazia preocupação tanto aos posseiros quanto

${ }^{289}$ NÓS Irmãos, Junho de 1974. In: COSTA SOBRINHO, Op. Cit. p. 164. 
aos compradores, e também estabelecer o contato permanente com os órgãos já citados com vista aos encaminhos adequados à problemática da terra. (COSTA SOBRINHO, Op. Cit. p. 165).

No entanto, a posição da Igreja Católica em todo o Território do Acre não era unânime pois a Prelazia do Juruá, de orientação mais conservadora e integrada por padres alemães não se envolveu nos conflitos pela posse da terra naquela localidade.

Outro aspecto importante que denota a resistência da "floresta" à morte que lhe estava sendo imposta foi a instalação da CONTAG (Confederação dos Trabalhadores Agrícolas) em julho de 1975, a qual se constituiu um suporte para os trabalhadores com o apoio da Igreja.

Este fato demonstra a preocupação da Igreja de organizar-se e aparelhar-se para melhor exercer seu papel em prol dos trabalhadores rurais e Povos da Floresta. Nessa direção, criou o CIMI (Conselho Indigenista Missionário) em 1975 e a CPT (Comissão Pastoral da Terra) no ano de 1976 e, com o passar dos anos, o CDDH (Centro de Defesa dos Direitos Humanos).

Por que a CONTAG veio para o Acre e que papel exerceu junto aos trabalhadores rurais?

Segundo COSTA SOBRINHO (1988, p. 169), a instalação da Delegacia da CONTAG no Acre não ocorreu devido a nenhuma solicitação formal da Igreja ou do INCRA, mas à necessidade que ela sentiu de atuar em todo o Brasil e, considerando que os territórios de Rondônia e Acre não dispunham ainda da presença da referida organização e, principalmente, por ser uma área conflituosa e carente de orientação, conforme eventuais solicitações de esclarecimentos de órgãos do governo do Acre, foi designado o economista João Maia para coordenar a citada Delegacia por possuir longa experiência na instituição e ter livre trânsito junto aos órgãos oficiais. 
Com a vinda da CONTAG, a gente começou a explicar a legislação e aí havia a vontade do pessoal se unir e resistir para, digamos, não perder a mata, não perder a seringa, a castanha e não perder a terra, mas estava faltando realmente alguém que orientasse, está aqui a Lei, em alguns casos você defende na prática resistindo, não é? Mas muitas vezes tem que entrar na justiça, tem que falar com autoridades, não é? Então o pessoal começou, digamos assim, a sentir o sabor de que aquela vontade de se organizar, quer dizer, tinha um respaldo, aí a coisa evoluiu realmente com a maior força ${ }^{290}$.

Tendo por base o Estatuto da Terra e o Código Civil de 1917, como base jurídica, a CONTAG estabeleceu como linha de ação alguns procedimentos, entre os quais a orientação para que o trabalhador rural permanecesse na terra, resistisse às pressões e não aceitasse indenizações, pois a lei 4.504, do Estatuto da Terra, assegurava-lhe a posse, após um ano e um dia; orientava o seringueiro a não pagar renda, pois tal fato implicaria o reconhecimento do dono da terra; e, também orientava o seringueiro a comprar mercadorias a quem lhe conviesse e a vender a borracha pelo melhor preço oferecido. Dessa forma, a segunda e terceira orientações implicava na extinção do seringalista e do arrendatário de seringais (COSTA SOBRINHO, Op. Cit. p. 171).

As ações da CONTAG começaram a germinar. Na medida que tinham o apoio da Igreja e do governador da época, Geraldo Gurgel de Mesquita, facilitaram de certa forma o trabalho do órgão, possibilitando a instituição do processo de criação de sindicatos rurais no Acre.

Dessa forma, em 20 de setembro de 1975, foi fundado o primeiro Sindicato dos Trabalhadores Rurais de Sena Madureira; ainda em 1975 (21 de dezembro) foi criado o Sindicato dos Trabalhadores Rurais de Brasiléia. No ano de 1976, mais dois sindicatos foram formados: o de Rio Branco (23 de maio) e o de Cruzeiro do Sul (11 de setembro). Em 1977 (9 de abril) foi criado o de Xapuri, fazendo com que, no prazo de dois anos após a sua fundação, a CONTAG criasse e assessorasse sete sindicatos, no que pese a conjuntura ser marcada pelo confronto e violência entre posseiros e fazendeiros.

${ }^{290}$ MAIA, João: depoimento: Entrevistadora. Eloisa Winter Nascimento, docente da UFAC. In: COSTA SOBRINHO, Op. Cit. p. 170. 
Dessa forma, os sindicatos de trabalhadores rurais passam a ser a fonte de referência das lutas sindicais no Estado do Acre, inclusive instituindo novas formas de luta, como a denominada de “empate”.

\begin{abstract}
Aí o Wilson Pinheiro [líder sindical de Brasiléia e depois presidente do STR] disse: daqui prá frente paulista nenhum vai mais abusar conosco, nós vamos empatar. O que que era o empate? Empatar significava que nós, para sobreviver aqui na floresta, nós não precisamos desmatar, nós não precisamos fazer o desmatamento.

Mas, também, se eles desmatarem nós não temos como ficar aqui, porque o que nós sabemos fazer é cortar seringa, quebrar castanha, trabalhar no extrativismo. Ninguém está adaptada à agricultura. Então nós vamos empatar: nem nós derrubamos nem eles derrubam, então está empate. Nós não derrubamos, mas eles também não derrubam. Só que para a gente era uma vitória, porque se a floresta ficasse de pé, a gente sobrevivia. ${ }^{291}$
\end{abstract}

O primeiro empate ocorreu no município de Brasiléia, em 1976, e desde então essa técnica de luta passou a ser utilizada nos demais municípios acreanos.

E, num crescente, os sindicatos foram se fortalecendo, e tornando-se cada vez mais combativos, sobretudo aqueles localizados nos vales do Acre e Purus.

Como peculiaridade, os empates no início eram só compostos por homens, porém, diante do acirramento dos conflitos, mulheres e crianças também passaram a fazer parte, o que, segundo ESTEVES, 1999, p. 144, contribuiu para garantir o caráter pacífico destes.

No entanto, essa posição não é aceita sem contestação.

O empate, quando surge, é um movimento armado. Não existe uma foto de empate em que os trabalhadores não estejam armados, só que não era um movimento de luta para a tomada de poder, mas de resistência armada. Não havia a intenção de montar um exército popular, como existia em Cuba, Bolívia, Peru ou existe na Colômbia ${ }^{292}$.

No entanto, não há registro de que nos empates tenha ocorrido confronto armado.

\footnotetext{
${ }^{291}$ RODRIGUES, Osmarino Amâncio; depoimento. [1997]. Entrevista realizada pela equipe de pesquisadores do projeto 'Seringueiro - memória, história e identidade”. Rio Branco, AC.

${ }^{292}$ PEDRINA, Celina: depoimento. Entrevista realizada por Horácio Antunes de Sant’Anna Júnior. Rio Branco. In: SANT'ANNA JÚNIOR, Horácio Antunes de. Florestania - a saga acreana e os povos da floresta. Rio Branco: EDUFAC, 2004. P. 198 - 199.
} 
Outro ponto a destacar foi a atuação, a partir de 1977, do jornal “O Varadouro”, que, assemelhado ao “Pasquim”, se constituía uma expressão da “imprensa alternativa”, dando voz ao "grito da floresta”.

\begin{abstract}
“O Varadouro saiu com a intenção de marcar uma posição em defesa dos posseiros, que era a questão mais imediata, da luta dos índios e das organizações que começavam a surgir nas cidades. Foi assim que surgiu " $O$ Varadouro”, com uma posição bem radical, por que houve muita radicalização do outro lado. Por isso nós tínhamos que marcar uma posição de defesa destes segmentos mais explorados. A idéia era ouvir os seringueiros, os marginalizados e conscientizar a população sobre o que ela estava passando, a violência que estava sofrendo ${ }^{293}$.
\end{abstract}

A respeito do Varadouro é importante assinalarmos que ao longo dos seus quatro anos de existência, pois surgiu em 1977 e deixou de circular em 1981, embora não tenha conseguido manter a periodicidade mensal, se constituiu veículo de denúncia do que ocorria em relação aos índios, a luta pela terra e a questão ambiental.

Nas eleições de 1978 para a composição dos representantes legislativos, "várias lideranças das CEBs e do movimento sindical engajaram-se na 'Frente Popular do MDB'. Todavia, as contradições vigentes no interior do partido dificultaram a consolidação deste como uma via de expressão política dos movimentos populares e sindicais. No final dos anos 70, seus componentes buscaram outra alternativa partidária”294.

Importante ressaltar que a década de 1980 foi também marcada pelos conflitos pela posse da terra, inclusive culminando em atos de violência ou assassinato, como o que ocorreu com Wilson Pinheiro, presidente do Sindicato de Brasiléia, morto em 21 de julho de 1980, o qual provocou grande revolta no seio do movimento sindical e popular. Inclusive, o desdobramento do ato público que marcou o sepultamento dele gerou prisões, torturas e

\footnotetext{
${ }^{293}$ SILVEIRA, Elson Martins da: depoimento. In: PAULA, Elder Andrade. Seringueiros e sindicatos: um povo da floresta em busca da liberdade. Rio de Janeiro: CPDA/UFRJ, 1991. p. 122 - 123.

${ }^{294}$ FERNANDES, Marcos Inácio. O PT no Acre: a construção de uma terceira via. Natal: UFRN, 1999, p. 52. In: SANT’ANA JÚNIOR, Op. Cit. p. 205.
} 
indiciamento na Lei de Segurança Nacional das lideranças presentes ao evento, como no caso de Lula e Jacó Bittar, representantes da direção nacional do PT.

No entanto, algo novo estava em formação no campo partidário - a criação do Partido dos Trabalhadores do Acre, em 12 de março de 1980, congregando várias lideranças sindicais, as quais constituíram a base de apoio do partido em todo o Estado do Acre. Gradativamente, migraram para as suas fileiras estudantes, intelectuais, lideranças urbanas e vários líderes de outros partidos.

Evidente que a composição interna do partido comportará visões políticas diferenciadas, quais sejam:

1) a Articulação, que era a corrente majoritária tanto nacional como localmente, tinha suas principais bases entre lideranças comunitárias e sindicais ligadas à Igreja, dentre as quais, o nome mais expressivo ainda hoje é o do Deputado Federal Nilson Mourão; 2) o PRC que se manteve como um partido leninista clandestino dentro do PT até 1989, abrigou personalidades que viriam obter muito destaque na política partidária e sindical; [. . .] 3) a Organização Socialista Internacionalista, Fração da Quarta Internacional ou Libelu (denominação da facção no movimento estudantil. [. . .] os "independentes" que na verdade não se constituíam em tendência, mas eram personalidades que atuavam no PT sem estarem vinculadas às tendências organizadas. ${ }^{295}$.

O fato é que o PT organizou-se e cresceu a partir de sua luta em favor dos extrativistas, questionando o modelo de desenvolvimento existente na época.

Nas eleições de 1982 para o governo do Estado, a primeira após os governos militares, o PT concorreu pela primeira vez, tendo como candidato Nilson Mourão, porém “obteve apenas 5,4\% dos votos” - o vencedor foi Nabor Telles da Rocha Júnior. No entanto, esse fato, considerando o contexto da época, foi relevante para os partidos assentarem suas bases legais.

Apenas no Acre, com Nilson Mourão (5,4\%), e em São Paulo, com Lula (9,8\%), o PT superou a meta estabelecida na legislação de atingir 3\% do

${ }^{295}$ FERNANDES, Marcos Inácio. O PT no Acre: a construção de uma terceira via. Natal: UFRN, 1999, p. 70-76. In: SANT’ANA JÚNIOR, Op. cit. p. 206. 
eleitorado. Quando se canaliza esses resultados [. . .], o desempenho do PT acreano não deixa de constituir um feito histórico da maior relevância $[. . .]^{296}$.

A perspectiva que se configurava para o partido era crescer, consolidar-se cada vez mais no campo da esquerda, e a conjugação de vários fatores como a criação da FETACRE (Federação dos Trabalhadores Rurais do Acre); a execução do PDI-AC (Projeto de Desenvolvimento Rural Integrado) através do IPEA (Instituto de Pesquisa Econômica Aplicada) destinado às áreas com maior concentração de produtores rurais; a fundação da CUT-AC (Central Única dos Trabalhadores); a repercussão regional, nacional e internacional da ação devastadora do POLONOROESTE, em Mato Grosso e Rondônia e as pressões ao governo federal e das agências financiadoras internacionais no que concerne à questão ambiental na Amazônia contribuíram sobremaneira para que o PT se consolidasse definitivamente e assumisse a questão ambiental e a luta dos extrativistas como a "razão de ser” do partido.

Todavia, mesmo consolidado, o PT não tinha densidade eleitoral para vencer as eleições municipais de 1985, pois o seu candidato, Raimundo Cardoso, obtivera apenas 3,32\% dos votos.

No entanto, o enfrentamento à questão prosseguia e a luta de Chico Mendes como líder sindical e ecológico ganhava espaço nacional e internacional. Em nível regional, os trabalhadores extrativas ampliavam a sua capacidade de organização criando, em 1985, o Conselho Nacional dos Seringueiros, tendo como contraponto a UDR (União Democrática Ruralista), e assumiu como ponto principal de luta a criação das Reservas Extrativistas (RESEXs).

O Conselho Nacional dos Seringueiros não pretendia e nem pretende ser um sindicato paralelo, mas uma entidade de seringueiros, porque os seringueiros nunca foram reconhecidos como classe. Os sindicatos surgiram com uma importância muito grande, num momento muito

296 FERNANDES, Marcos Inácio. O PT no Acre: a construção de uma terceira via. Natal: UFRN, 1999. p. 95 In: SANT’ANA JÚNIOR. Op. Cit. p. 211. 
importante. Mas os sindicatos dos trabalhadores rurais congregam seringueiros e ao mesmo tempo os agricultores, os peões, os trabalhadores de fazenda, os diaristas, qualquer que seja o trabalhador rural. As outras classes tem o reconhecimento como classe, o seringueiro não. Parece uma coisa que foi passado e que não existia mais. Então, uma das razões do Conselho Nacional dos Seringueiros é fazer reconhecer o seringueiro como uma classe que já deu a sua contribuição, que luta e que tem uma luta importante, luta por um objetivo muito importante que é a defesa da Amazônia. Esta idéia pegou bem [. . . $]^{297}$.

Como parte desse processo, um elo de solidariedade foi unindo o movimento dos trabalhadores, inclusive estabelecendo laços entre os rurais e os urbanos frente aos enfrentamentos dos extrativistas com os “novos donos do Acre”.

E, nas eleições de 1986, o PT concorre ao governo do Estado do Acre, tendo como candidato Hélio Pimenta, porém o vencedor do pleito foi novamente o PMDB, com Flaviano Melo, cujo plano de governo “Diretrizes de governo 1987/1991” “demonstrou preocupações com as críticas ao estilo de desenvolvimento existente e seus efeitos econômicos e sociais"298. E, mais ainda, criou dois órgãos: o IMAC (Instituto de Meio Ambiente do Acre) e a FUNTAC (Fundação de Tecnologia do Acre), os quais serão de relevante valia para as discussões ambientalistas e o desenvolvimento de projetos de intervenção a esse respeito.

No ano de 1987, o movimento dos seringueiros consegue o reconhecimento internacional da sua luta, quando Chico Mendes, na época presidente do Sindicato dos Trabalhadores Rurais de Xapuri, recebe o Prêmio Global 500, concedido pela ONU (Organização das Nações Unidas).

A partir de então, Chico Mendes adentrou o cenário internacional na condição de “tribuno da floresta” e concentrou suas ações em ampliar o leque de aliados nos setores sociais externos a floresta, compreendendo desde os trabalhadores urbanos do Acre às grandes organizações ambientais internacionais, e atuará, também, para construir uma aliança com os

\footnotetext{
${ }^{297}$ MENDES, Chico. Depoimento: In: GRZYBOWSKI Cândido (Org.). O testamento do homem da floresta: Chico Mendes por ele mesmo. Rio de Janeiro. FASE, 1989. p. 26.

298 SILVA, José Portiro. Preservação e sutileza: a política de desenvolvimento do governo do Acre (19841990). Rio de Janeiro: CPDA/UFRJ, 1998, p. 65 In: SANT’ANA JÚNIOR, Op. Cit. p. 228.
} 
povos indígenas, os que ao longo do processo histórico de constituição do Acre sofreram um processo brutal de expropriação de suas terras, configurando o que mais tarde passou a ser denominado de “aliança dos povos da floresta”.

Em função de sua combatividade, penetração nacional e internacional, a luta de Chico Mendes foi interrompida bruscamente com o seu assassinato em 22 de dezembro de 1988.

Porém, a morte do líder sindical não arrefeceu as articulações no sentido de consolidar a ação conjunta de índios e seringueiros, que em 1989 consolidou-se definitivamente.

O I Encontro dos Povos Indígenas do Xingu (realizado em Altamira-PA) entre 20 e 25 de fevereiro de 1989 e o I Encontro dos Povos da Floresta (realizado em Rio Branco - AC entre 25 e 31 de março de 1989, juntamente com o II Encontro Nacional dos Seringueiros) desdobraram-se na denominada Aliança dos Povos da Floresta, articulação formada pela União das Nações Indígenas-UNI e pelo Conselho Nacional dos Seringueiros - CNS, que foi lançada em São Paulo, no dia 12 de maio de 1989. Os objetivos dessa aliança, consoante declaração do Coordenador da UNI, serão os de promover a defesa do ecossistema amazônico, para que não sejam destruídos os recursos naturais e os povos da região. Suas formas de mobilização são amplas e abrangem o conjunto de segmentos sociais que mantém diferentes níveis de contradição com os aparelhos do poder e os novos grupos interessados nas terras ${ }^{299}$.

Outro fator que merece destaque é a instituição legal das reservas extrativistas no “apagar das luzes” do governo Sarney. A efetiva criação de diversas reservas extrativistas, áreas em que a preservação do meio ambiente deve ocorrer sem a exclusão da população que tradicionalmente as ocupavam, e das quais a Reserva Extrativista do Alto Juruá foi a primeira, só veio a constituir-se uma oportunidade histórica de demonstrar a sustentabilidade do modo de vida dos seringueiros. ${ }^{300}$

É inconteste que, com as reservas extrativistas,

\footnotetext{
${ }^{299}$ ALMEIDA, Alfredo Wagner Berno de. Política de Conflitos - o movimento dos trabalhadores rurais e os conflitos agrários na Amazônia. In: Caderno do CEDI. Sindicalismo no campo: reflexões: balanços e controvérsias. Rio de Janeiro: CEDI, 1991, p. 106. In: SANT’ANA JÚNIOR, Op. Cit. p. 233.

${ }^{300}$ WOLFF, Cristina Scheibe. Mulheres da floresta: uma história: Alto Juruá-Acre (1890-1945). São Paulo: Hucitec, 1999, p. 142. In: SANT’ANA JÚNIOR, Op. Cit. p. 235.
} 
A situação mudou, e com ela a validade dos antigos paradigmas. As populações tradicionais não estão mais fora da economia central nem estão mais simplesmente na periferia do sistema mundial. As populações tradicionais e suas organizações não tratam apenas com fazendeiros, madeireiros e garimpeiros. Elas tornaram-se parcerias de instituições centrais como a Nações Unidas, o Banco Mundial e as poderosas ONG's do Primeiro Mundo. Tampouco o mercado no qual hoje atuam as populações tradicionais é o mesmo de ontem. Até recentemente as sociedades indígenas, para obter renda monetária, forneciam mercadorias de primeira geração: matérias-primas como a borracha, castanha do Pará, minérios e madeira. Elas pularam a segunda geração de mercadorias com valor agregado industrial e mal passaram pelos serviços ou mercadorias de terceira geração. E começaram a participar da economia da informação as mercadorias de quarta geração - por meio de valor agregado ao conhecimento indígena e local. . . e entraram no mercado emergente dos "valores de existência”, como a biodiversidade e as paisagens naturais $[\ldots]^{301}$

No entanto, foi a partir das eleições de 1990, quando a Frente Popular do Acre (FPA), numa coligação composta pelo PT, PCB, PC do B, PDT e PV, lançou a candidatura de Jorge Viana para o governo do Estado do Acre, que a “invenção do Acre viável” ganhou nova dimensão, pois se até então o movimento sindical, ecológico e popular tinha demarcado o seu espaço no leque partidário existente, de 1990 em diante passou a se constituir numa força política real com estrutura suficiente para ameaçar o status quo "reinante”, na perspectiva de chegar ao governo no Estado do Acre.

\footnotetext{
301 ALMEIDA, Mauro Willian Barbosa de, CUNHA, Manuela Carneiro da. Populações tradicionais e conservação ambiental. In: CAPOBIANCO, João Paulo Ribeiro et al (org.). Biodiversidade na Amazônia brasileira: avaliação e ações prioritárias para conservação, uso sustentável e repartição de benefícios. São Paulo: Estação Liberdade: Instituto Socioambiental, 2001, p. 188 In: SANT’ANA JÚNIOR, Op. Cit. p. 236.
} 
4.2 - A floresta envergonhada e as novas representações da autonomia acreana

Possuímos um bem conquistado

Nobremente com armas na mão.

Se o afrontarem de cada soldado

Surgirá de repente um leão. . .

Hino Acreano

A década de 1990 tem início no Acre anunciando a necessidade da construção e implementação de um novo modelo de desenvolvimento, bem como a moralização da administração pública frente aos escândalos noticiados pela mídia local e nacional contribuindo para a construção de um imaginário do Acre como uma terra sem jeito, entregue à própria sorte, na contramão de lei. Essa representação tornou-se ainda mais forte quando da CPI do Narcotráfico envolvendo autoridades da região.

Este fato fez com que o PT lançasse como slogan de campanha eleitoral a expressão “O Acre tem jeito”.

O que significa o “Acre tem jeito?” É uma forte expressão de apelo popular referenciada na história do Acre. A forma declarativa e categórica da frase, mais do que um marketing de campanha política fez com que o discurso de Jorge Viana ganhasse dinâmica e funcionalidade.

Por outro lado, as características do jovem político Jorge Viana, como bem-apessoado, carismático, engenheiro florestal, discurso articulado e envolvente e, além de tudo, filho da "tradição" da floresta, constituíam fortes elementos de persuasão, convencimento, de que algo novo estava surgindo no cenário da política acreana.

E a força do seu discurso estava fundamentada numa nova leitura do acreanismo, o que implicou uma apropriação dos ícones da história acreana, na perspectiva de significar a identidade do Acre e dos acreanos. "O discurso é o efeito de sentidos entre locutores" (ORLANDI, 1999, p. 21). 
O domínio do imaginário, do simbólico, tornou-se um importante lugar estratégico no discurso do governo estadual.

E, neste sentido, imaginário não significa ilusório, mas sim buscar no sagrado, naquilo que mais forte falava à alma da gente acreana, os elementos para a construção de uma outra imagem do Acre.

Exercer um poder simbólico não consiste meramente em acrescentar o ilusório a uma potência real, mas, sim em duplicar e reforçar a dominação efetiva pela apropriação dos símbolos e garantir a obediência pela conjugação das relações entre sentido e poder. Os emblemas do poder, os monumentos erigidos em sua glória, o carisma do líder. ${ }^{302}$

O sistema de representações que o candidato Jorge Viana utilizou traduzir e legitimava o novo tempo, o tempo da floresta. Se esta, ao longo de todo o processo histórico de constituição do Acre foi negada ou silenciada, a partir de então, como fênix, a floresta ressurge em todo o seu esplendor. É o imaginário a serviço da mudança social.

Importante considerarmos que governar é fazer acreditar, o que, por sua vez, denota as íntimas relações entre o poder e o imaginário.

Se até então o imaginário que o restante do Brasil e o mundo tinham do Acre era de uma terra de conflito, de uma terra onde se vivia na contramão da ordem, o novo discurso construído busca no sagrado a sua legitimidade, e embora não tenha sido vencedor do pleito eleitoral, inegavelmente a "semente estava lançada”.

Foi efetivamente, com a vitória para administração da cidade de Rio Branco em 1993, numa ampla coligação que envolvia o PT, PC do B, PPS, PDT, PV e PSDB, que Jorge Viana começou a dar corpo institucionalmente a uma proposta de governo calcada na exaltação dos valores, crenças e tradições da região.

${ }^{302}$ BAEZO, B. Imaginação social. In: Enciclopédia Einandi. Portugal: Imprensa Nacional/Casa de Moeda, 1985, p. 299. 
A “vida nova na cidade” traduzia, naquele contexto, onde a exclusão social apresenta a sua face mais cruel, a possibilidade de que se a cidade tinha jeito, o Acre como um todo poderia responder aos desafios com que se defrontava.

A esperança de dias melhores, a ênfase nas expectativas e aspirações de múltipla “gente da floresta” são o cerne do imaginário político como o locus do sonho, do desejo, da crença, mas, também, da luta, do conflito com as forças que oprimem.

Importante acrescentar que as eleições de 1998 no Acre ocorreram num contexto marcado por denúncias de corrupção, esquadrão da morte, narcotráfico, crime organizado veiculados na mídia nacional (Revista Época, Folha de S. Paulo, Jornal do Brasil) e essas notícias contribuíram para que a opinião pública construísse um imaginário do Acre como uma terra sem ordem, onde o banditismo “campeava”.

Diante desses fatos, foi formada pela Câmara Federal a Comissão Parlamentar de Inquérito do Narcotráfico, cujo desfecho gerou processos e prisões de autoridades da região.

A CPI do Narcotráfico atuou em todo o país e, junto com o Ministério Público Federal e Estadual, com a Justiça Acreana e com a Polícia Federal viabilizou o clima de tranqüilidade no Acre do ponto de vista do esquadrão da morte, do tráfico de drogas. Hoje o Acre tem outro tipo de violência, que é do furto pequeno, do crime localizado, mas o esquadrão e quadrilhas foram desmontadas $[\ldots]^{303}$

Frente ao clima de inquietação reinante, a possibilidade concreta de a Frente Popular ser bem sucedida no pleito eleitoral para o governo do Estado implicava o estabelecimento de uma ampla coligação.

Dessa forma, doze partidos (PT, PSDB, PC do B, PMN, PL, PDT, PPS, PV, PTB, PT do B, PSB e PSL) apoiaram a chapa Jorge Viana (PT) e Edson Cadaxo (PSDB), respectivamente para governador e vice-governador do Acre.

${ }^{303}$ VASCONCELOS, Raimundo Angelim: depoimento [23 de junho de 2000]. Entrevistador: Horácio Antunes Sant’Ana Júnior. Rio Branco. In: SANT’ANA JÚNIOR, Op. cit. p. 250. 
No processo eleitoral, tinha-se o diagnóstico de que sem alianças não se ganharia a eleição, sendo necessário flexibilizar a visão de quais deveriam ser os aliados. Se a aliança fosse restrita a PC do B, PV, PSB e PDT, aliados de outros embates eleitorais, não se ganharia a eleição. $O$ grande problema no arco de alianças, composto por 12 partidos era a presença do PSDB pelo que simbolizava na disputa de governo e que poderia interferir na política nacional de alianças do PT. Foi assim objeto de discussão na convenção nacional do PT, que autorizou a aliança local, em caráter de exceção. A necessidade de uma aliança ampla se justificava pela necessidade de um exército de candidatos proporcionais (deputados) fazendo campanha para o candidato a governador, já que a direita sempre teve um número maior de candidatos. Outro aspecto era a possibilidade de um tempo maior de propaganda na televisão [. . . $]^{304}$

O anseio por mudanças não apenas do movimento sindical e dos extrativistas em particular, mas de grande parte da sociedade acreana, diante dos escândalos envolvendo autoridades do Estado explicam alianças entre atores políticos convencionalmente opostos e com profundas divergências.

Outro aspecto que contribuiu para a vitória de Jorge Viana ao governo do Estado em 1998 foi a bem sucedida administração do município de Rio Branco no período de 1993 a 1996 e, sobretudo, o trabalho de base que desenvolveu durante dois anos, ao longo dos quais percorreu os municípios acreanos mantendo contatos com as lideranças dos vários segmentos da sociedade local na perspectiva de aglutinar forças para o embate pela gestão do Estado do Acre.

Foi neste contexto que surgiu a idéia de formular um documento que expressasse as diretrizes do governo denominado “A vida vai melhorar”.

É através das representações ideológicas que uma classe exprime as suas aspirações, justifica moral e juridicamente seus objetivos concebe o passado e imagina o futuro. [. . .] Assim é produzida uma representação global e totalizante da sociedade como uma ordem, em que cada elemento encontra o seu "lugar", sua identidade e sua razão de ser ${ }^{305}$

\footnotetext{
${ }^{304}$ NEPOMUCENO, Francisco (Carioca). Depoimento: [24 de novembro de 2000]. Entrevistador: Horácio Antunes Sant'Ana Júnior. Rio Branco: In: SANT’ANA JÚNIOR. Op. cit. p. 252.

${ }^{305}$ BAEZO, B. Imaginação social. In: Enciclopédia Einandi. Portugal: Imprensa Nacional/Casa de Moeda, 1985, p. 309.
} 
Como contemplar as múltiplas necessidades e aspirações dos diversos sujeitos sociais presentes no chão acreano?

Do diálogo com os vários segmentos o plano de governo foi estruturado tendo como eixo central o desenvolvimento sustentável, priorizando as reservas extrativistas, o uso de recursos naturais de forma racional e inteligente, voltado para o extrativismo. Esta decisão foi tomada com base em três tipos de consulta: a popular, a estudiosos e aos partidos políticos que formavam o Conselho Político da Frente Popular.

A Frente venceu o pleito para o executivo estadual com 57,7\% dos votos.

A perspectiva da reafirmação da identidade do Acre e dos acreanos, como o povo da floresta, significou um resgate histórico, pois até então, a floresta era vista como atraso e seus atores sociais, as populações tradicionais como bárbaros, selvagens, ignorantes, preguiçosos, atrasados, por outro significou também a incorporação das idéias de Chico Mendes e outros líderes sindicais extrativistas e ecológicos que fizeram o "grito" da floresta ecoar no mundo afora...

O governo partiu do diagnóstico de que o modelo de desenvolvimento anterior levou a perda de milhões de dólares na exportação da madeira em toras e de que a falta de incentivos levou a queda assustadora da produção de borracha, provocando o êxodo das florestas, com as famílias de seringueiros vindo para as periferias das cidades provocando marginalização, prostituição e alcoolismo de seus membros e o aumento da violência urbana. Ao assumir, o governo provocou um rearranjo da estrutura organizacional do Estado, criou a Secretaria de Florestas e Extrativismo, voltada exclusivamente para o setor extrativista; criou a Secretaria de Produção vinculando a ela todas as secretarias do setor produtivo: indústria, comércio, serviços, agricultura, pecuária e extrativismo. A Secretaria de Produção discute as políticas e as outras são executivas desta política. A Secretaria de Extrativismo não é a mais importante mas tem a função de resgatar o extrativismo, que faz parte da história do Acre, implantando a florestania $[\ldots]^{306}$.

${ }^{306}$ VASCONCELOS, Raimundo Angelim: depoimento [23 de junho de 2000]. Entrevistador: Horácio Antunes Sant’Ana Júnior. Rio Branco. In: SANT’ANA JÚNIOR, Op. cit. p. 261. 
No entanto, faz-se necessário frisar que, embora a Secretaria de Extrativismo seja o “carro-chefe” do governo, do desenvolvimento sustentável, outras áreas também são priorizadas como a pequena e microempresa, o cooperativismo, o associativismo, a saúde, a educação e a segurança.

A metáfora “governo da floresta” é por nós lida como “a floresta governa”, na medida que esta, num certo sentido, sempre “governou”, porém não de forma reconhecida e institucionalizada.

E a "noção de metáfora [. . . e é imprescindível na análise do discurso. Ela não é considerada como na retórica, como figura de linguagem. A metáfora [. . .] é aqui definida como a tomada de uma palavra por outra. Na análise de discurso, ela significa basicamente "transferência", estabelecendo o modo como as palavras significam ${ }^{307}$.

Relembrar a luta dos que vêm inventando o Acre permite reencontrar o pertencimento.

Quem sou eu? Quem é minha tribo? Indo ao passado, a gente do Acre reencontrou-se, reafirmou a identidade, passou a ter orgulho de ser o que é. A dignidade de um povo, com suas crenças, valores, tradições, suas culturas, seus modos de vida, é reconhecida e respeitada.

A verdadeira percepção do passado consistia em considerar que ele não era verdadeiramente passado. Um esforço de lembrança poderia ressuscitá-lo; o presente tornando-se, ele próprio, a sua maneira, um passado reconduzido, atualizado, conjurado enquanto presente por essa solda e por essa ancoragem. Sem dúvida, para que haja um sentimento do passado é necessário que ocorra uma brecha entre o presente e o passado, que apareça um "antes" e um "depois" 308 .

E a busca da construção de outro modelo de desenvolvimento conduziu à sustentabilidade, entendendo-se esta por economia de pequena produção capaz de gerar renda

\footnotetext{
${ }^{307}$ ORLANDI, Eni P. Análise de discurso - princípios e procedimentos. Campinas, SP: Pontes, 1999, p. 44. ${ }^{308}$ NORA, Pierre. Entre memória e história - a problemática dos lugares. In: História: Revista do Programa de Estudos Pós-Graduados em História e do Departamento de Histórica da PUC-SP (Pontifícia Universidade Católica de São Paulo) São Paulo, 1981. P. 18-19.
} 
e dessa forma contribuir para a correção das desigualdades sociais e manutenção do ecossistema florestal.

O princípio básico dessa proposta de desenvolvimento seria proteger a Amazônia e suas riquezas naturais de interesses externos a esta defendendo uma forma de ocupação que respeitasse os direitos das populações tradicionais que secularmente vêm protegendo a floresta.

Ao passo que a visão antagônica parte do pressuposto que o extrativismo vegetal é por si só incapaz de promover os resultados econômicos necessários à ruptura do padrão de desenvolvimento vigente, o qual reproduz as condições de pobreza e miséria atuais.

E nesse contexto, insere-se a discussão da preservação da floresta amazônica como uma questão de interesse nacional e internacional, que, por sua vez, liga-se as crescentes preocupações com as questões ambientais, particularmente com o aquecimento do planeta e a perda da biodiversidade, o que remete, também às questões relativas ao acesso e uso de terra.

Importante também considerar que foi a partir da década de 1970 que se ampliaram as discussões acerca da formação de uma consciência ecológica global, sendo, também, como já abordarmos anteriormente, um marco do processo de ocupação da Amazônia/Acre através da implantação de um modelo de desenvolvimento assentado na grande empresa agropecuária, cuja lógica era a transformação da floresta em pasto, tudo isso apoiado pelo conjunto de políticas definidas pela “Operação Amazônia” que considerava a região amazônica um imenso vazio demográfico que precisava ser integrado ao Brasil.

A implantação desse modelo de desenvolvimento tinha como padrão o uso intensivo e predatório dos recursos naturais e, dessa forma tornou-se uma ameaça as populações locais e à floresta tropical. 
Essa maneira de apropriação da natureza resultou na instauração de um forte processo de degradação ambiental e do outro na resistência a este modelo através dos movimentos sociais relacionados a terra, aos índios e aos trabalhadores rurais extrativistas.

Outro aspecto a mencionar é que a idéia das Reservas Extrativistas (RESEX) emergiu em 1985 como parte do movimento de resistência dos seringueiros acreanos à expropriação da terra e ao processo de devastação da floresta, constituindo uma “novidade” por ser resultante direta da luta política dos seringueiros acreanos que, têm a experiência de por mais de um século viverem da exploração dos produtos da floresta causando pouco ou quase nenhum dano ao ecossistema florestal.

Foi em decorrência do surgimento de um processo de venda de terras no Acre para investimentos na pecuária e especulação fundiária que a terra desmatada passou a ter maior relevância, implicando a disseminação da prática do deflorestamento.

Rio Branco era uma balbúdia, [. . .] você não tinha lugar para comer, para se hospedar, não tinha táxi, a cidade era um formigueiro. [. . . ] só a cidade de Rio Branco registrava entrada de hóspedes nos hotéis e pensões num total de 14.690, 18.925 e 20.549, respectivamente para o triênio 1971/73 [. . . ] Chegaram e começaram a comprar terras. A maioria dessas terras têm muitos vícios de origem. Ainda assim, compraram. Acreditavam que, no final, uma solução política samiaria o problema e, ao que parece, se deram mal. Enquanto se sentiam fortes atacavam o INCRA. Depois passaram a vítimas. O comentário de um advogado foi elucidativo: “todas as facilidades colocadas a disposição dos empresários por órgãos como a SUDAM, SUDHEVEA e ACAR [. . .] não podem ser alcançadas porque outro órgão, também federal, o INCRA, nos põe uma pedra no caminho. ${ }^{309}$

Como efeito dessa "romaria” de investidores, praticamente dois terços das terras do Estado do Acre foram vendidas, revendidas e extraordinariamente valorizadas.

Diante do exposto, os seringueiros organizadamente elaboraram uma proposta inovadora e alternativa que tem como elementos essenciais a melhoria de vida e a valorização

${ }^{309}$ O Globo. Amazônia, seus programas. .. Acre: problema com a especulação da terra. Rio de Janeiro. 21 de maio de 1975. Panorama Econômico, p. 234 - 238. In: COSTA SOBRINHO, Op. Cit., p. 62. 
dos produtos da floresta na perspectiva da melhoria do conjunto das populações tradicionais. Este fato explica o grau de aceitação das Reservas Extrativistas por parte das "populações da floresta”, além do trabalho político realizado por Chico Mendes na década de 1980, por cientistas e organizações ambientalistas de todo o mundo.

A proposta da RESEX foi sendo amadurecida ao longo de toda a década de 1980, no sentido de sua ampliação e melhor fundamentação e, esta passa a ser encampada pelo Conselho Nacional dos Seringueiros.

Embora não se constitua objetivo do presente trabalho a discussão das RESEX em profundidade, é importante ressaltar que a linha de raciocínio de preservação ambiental como elemento básico e articulador dos princípios de sustentabilidade enseja a elaboração do conceito de neoextrativismo.

Essa categoria conceitual foi elaborado por José Fernando do Rego que, em sua dissertação de Mestrado fez um estudo detalhado das políticas públicas de incentivo a produção de borracha na Amazônia, sendo este, atualmente, Secretário da Produção no governo do Estado do Acre.

Por neoextrativismo, Rego entende uma organização da produção familiar, todavia perpassando todas as instâncias da vida social, econômica, política e cultural. Dessa forma, o neoextrativismo implica uma elevação no nível de qualidade vida, principalmente pela elevação e geração de renda em decorrência da incorporação do progresso técnico e de novas alternativas de extração de recursos associados ao cultivo, criação, beneficiamento e comercialização da produção.

Vale destacar que a concepção do neoextrativismo se encontra ainda em estágio embrionário, porém desde já se apresenta como uma proposta que visa se constituir uma forma ampla de organização da produção baseada em princípios da sustentabilidade, porém 
redefine o conceito de extrativismo que passa a ser considerado algo mais amplo que a simples coleta de recursos naturais como ocorre no extrativismo mineral.

Ainda a esse respeito cabe acentuar que o conceito de neoextrativismo mostra-se adequado a discussão de viabilidade das reservas, notadamente no que se refere a ruptura aos moldes produtivos de organização produtiva dos seringais tradicionais.

E, neste aspecto, o Estado deve assumir um grande papel quanto a integridade dos espaços territoriais definidos como Resex, além do fato de que a concessão real de uso deve ser regulada através de contexto aprovado pelo IBAMA, além de se contrapor ao desmatamento na Amazônia.

Importante considerar que a morte de Chico Mendes em 1988 contribuiu politicamente para que as reservas extrativista passassem a ser vistas como novo paradigma de desenvolvimento para a região amazônica, recebendo estas, apoio de organizações nãogovernamentais, universidades, instituições de pesquisa e agências de desenvolvimento dentro e fora do Brasil.

No entanto, a proposta das RESEX não constitui unanimidade, há os que argumentam que as reservas por serem baseadas no extrativismo vegetal representam uma proposta de perpetuação da miséria. Nesse sentido, consideram que as RESEX são incapazes de incorporar progresso técnico, não se adaptam a um sistema de alta escala da produção, sendo ainda impossível através destas gerar rentabilidade média compatível com os padrões estabelecidos na região. Argumentam ainda que, a instabilidade na atividade extrativa vegetal não permite considerá-la um modelo de desenvolvimento viável para a Amazônia.

Frente a posições tão dispares o governo do Estado do Acre optou por instituir as RESEX como expressão do desenvolvimento sustentável. A perspectiva política era inventar uma “economia da floresta” compatível com o "governo da floresta”, emblema adotado 
como ícone da administração dos herdeiros da luta de Chico Mendes, compatível com a releitura do termo autonomia e a construção de um novo imaginário político.

Como construí-lo? A partir de que referenciais? As condições para a produção do novo discurso político do Estado, implicou em dar novos sentidos ao termo autonomia que, se no passado tinha sido utilizado por forças políticas conservadoras, passava, a partir de então, a ser utilizada por forças políticas de esquerda.

E, nesse contexto, autonomia passa a significar libertação, independência, preservação da natureza, melhoria de vida, moralização da coisa pública...

O sentido não existe em si, mas é determinado pelas posições ideológicas colocadas em jogo no processo sócio-histórico em que as palavras são produzidas. As palavras mudam de sentido segundo as posições daqueles que as empregam. Elas "tiram” seu sentido dessas posições, isto é, em relação as formações ideológicas nas quais essas posições se inscrevem. ${ }^{310}$

A partir da nova conjuntura sócio-histórica do Acre, nos anos 90, era definido o que podia e devia ser dito e, sobretudo como devia ser dito.

Ir ao passado do Acre, conhecer e exaltar esse passado de bravura passou a ser a estratégia política utilizada pelo governo estadual para afirmação do Acre nos cenários nacional e estrangeiro . E, como parte desta prática política foram destinados investimentos governamentais para a revitalização do patrimônio histórico do Acre - restauração e inauguração do Palácio Rio Branco e do seu parque-jardim, do casario antigo do Segundo Distrito, construção do Memorial da Autonomia acreana, tombamentos dos bens patrimoniais da população acreana, republicação de obras esgotadas e publicação de livros atuais sobre a história do Acre, dentre outras ações de menor impacto político, além de ações direcionadas a divulgação do Acre na mídia nacional.

${ }^{310}$ ORLANDI, Eni P. Análise de discurso - princípios e procedimentos. Campinas, SP: Pontes, 1999, p. 4243. 
Na visão do discurso político instituído, da floresta amazônica e suas riquezas, especialmente os povos da floresta, as populações ribeirinhas, deveria emergir o projeto de um Acre autônomo economicamente, o que só seria possível através do “governo da floresta”, que passou a disseminar como logomarca de sua administração a imagem de uma seringueira.

E o discurso construído utiliza uma linguagem que se inscreve na história do Acre, mormente na epopéia acreana vivida pelos nordestinos-seringueiros durante a Revolução Acreana.

A partir da simbologia criada o governo recém-instituído, busca-se produzir os sentidos de coragem, disposição de luta, esperança no futuro, superação do atraso, frente à realidade social, econômica e política do Acre, em meados dos anos 90.

[. . .] o que é dito em um discurso e o que é dito em outro, o que é dito de um modo e o que é dito de outro, procurando escutar o não-dito naquilo que é dito, como uma presença de uma ausência necessária. [. . .] Só uma parte do dizível é acessível ao sujeito pois mesmo o que ele não diz (e que muitas vezes ele desconhece) significa em suas palavras. ${ }^{311}$

O discurso passa a ser o território da mudança centrado no amplo apoio das lideranças extrativistas e das organizações ambientalistas. A partir de então, a palavra de ordem passa a ser sustentabilidade alicerçada em projetos específicos, ações pontuais que não provocam os resultados de impacto almejados.

Sustentabilidade de longo prazo implica, necessariamente, a redefinição dos rumos do desenvolvimento da nação brasileira. [. . . .] o desenvolvimento da região amazônica [deve ser visto] como parte indissociável de um projeto de reconstrução da nação, sem reduzi-la, contudo, a um utilitarismo de base nacionalista. É preciso considerar o seu significado para os sentidos mais nobres da vida da população mundial e combater incessantemente os sentidos mais pobres que a lógica da exploração “destrutiva do capital” impõe sobre ela. ${ }^{312}$

${ }^{311}$ ORLANDI, Op. Cit. p.34.

312 PAULA, Elder Andrade de. Estado e desenvolvimento insustentável na Amazônia Ocidental: dos missionários do progresso aos mercadores da natureza. Rio de Janeiro: UFRRJ, 2003, p. 244. 
Concebendo a sustentabilidade como o cerne do governo, a construção do imaginário do Acre como uma “terra que tem jeito" vai se consolidando à medida que lideranças e intelectuais ligados aos movimentos sociais e ambientalistas são alçados à estrutura de poder. O clima passa a ser o de alvorecer de um novo tempo para o Acre e os acreanos. E o discurso autonomista centrado no simbolismo do passado histórico do Acre passa a ressignificar os embates do presente.

[. . .] É assim que suas palavras adquirem sentido, é assim que elas se significam retomando palavras já existentes como se as classes originassem neles e é assim que sentidos e sujeitos estão sempre em movimento, significando sempre de muitas e variadas maneiras. Sempre as mesmas, ao mesmo tempo, sempre outras. ${ }^{313}$

Inspirado nas idéias e palavra de um outro tempo, do tempo em que o Acre se libertou do jugo do estrangeiro (Bolívia e Peru), ungindo heróis como Plácido de Castro, José Guiomard dos Santos, Chico Mendes e até o que ficou durante muito tempo na marginalidade histórica, José Augusto de Araújo, o governo de coalisão do Acre, mas com perfil de esquerda e amplo apoio dos movimentos sociais imprime na sua administração a marca da mudança.

A mídia local e nacional passa a ser o locus privilegiado para a divulgação da nova imagem do Acre. E o discurso do governo anula quaisquer outros discursos discordantes.

Palavras iguais podem significar diferentemente porque se inscrevem em formações discursivas diferentes. [. . .] observando as condições de produção [do discurso] e verificando o funcionamento da memória, ele deve remeter o dizer a uma formação discursiva (e não outra) para compreender o sentido do que ali está dito. ${ }^{314}$

Por outro lado, no entendimento de ideologia, não como mascaramento ou ocultação da realidade, mas, como função da relação entre linguagem e mundo e, ao mesmo tempo,

${ }^{313}$ ORLANDI, Op. Cit. p. 36

${ }^{314}$ Ibid. Op. Cit. p. 45. 
evidenciando que não há discurso sem sujeito. E não há sujeito sem ideologia. Ideologia e inconsciente estão materialmente interligados pela língua que professa o discurso.

Dessa forma, o discurso foi um instrumento que contribuiu para a vitória do candidato Jorge Viana no pleito eleitoral para o governo do Estado em 1998, garantir a reeleição em 2002 e explica o nível de aceitação do governo na atualidade em mais de 50\%.

Devemos ainda ressaltar que o projeto de invenção do Acre viável que está em curso não é uma unanimidade no seio das esquerdas do Acre.

Elder Andrade de Paula, professor do Departamento de Filosofia e Ciências Sociais da UFAC, constitui uma dessas vozes dissonantes e, neste sentido, na tese de doutorado "Estado e desenvolvimento insustentável na Amazônia Ocidental: dos missionários do progresso aos mercadores da natureza”, defendida no ano passado junto a UFRRJ, questiona de forma enfática a tese de desenvolvimento sustentável.

Segundo sua análise, o que está sendo desenvolvido na realidade é o desenvolvimento insustentável.

Esse negócio de autonomia do Acre é estupendo. Enquanto estão dizendo isso, estão assinando contratos com o Banco Mundial, que nega qualquer possibilidade de autonomia. Partem de um modelo de desenvolvimento que nega qualquer autonomia. As contas do governo do Estado são todas monitoradas no nível macro pelo Banco Mundial. Todos esses projetos que são aprovados aqui estão condicionados a um controle rígido das agências governamentais. $\mathrm{O}$ que pode e o que não pode. Há um abismo enorme entre o que se fala e o que se faz. E a idéia dominante que fica é que de fato tem uma invenção [... . $]^{315}$.

Na realidade, para Elder Paula, a expressão “governo da floresta” é um jargão de governo que faz a tentativa de estabelecer uma identidade entre propósitos conservacionistas e propósitos econômicos. A expressão “governo da floresta” passa a noção de que é possível harmonizar desenvolvimento social com desenvolvimento econômico, com base na

${ }^{315}$ PAULA, Elder Andrade: depoimento [11 de agosto de 2004]. Entrevistadora: Maria José Bezerra. Rio Branco. 
apropriação de uma aliança dos povos da floresta que foi bem construída porque se apropria do que já está no imaginário.

O Acre tem jeito. Que jeito? Esse de não perder a canoa. Se a canoa está remando para o mercado, então vamos lá, vamos ver se entramos nisso daí. Tem estrada, polo para a agricultura. . . Tentam mostrar que o Acre tem jeito. Há como colocá-lo dentro de uma ordem. Ele não é avesso a ordem, a tradição. Isso ajudou para diacho. O que está aqui é insustentável pelo que eles dizem que é sustentável eu digo que é insustentável. E porque é insustentável? Porque não garante nenhum desses quatro componentes que eles dizem que precisa ter para ter sustentabilidade. O tipo de exploração predominante é altamente prejudicial e destrutiva. Essa combinação de exploração madeireira com expansão da pecuária é perversa. Os dados estão mostrando isso $[\ldots]^{316}$.

Fica evidente que, para Elder Paula, não há sustentabilidade econômica nem social e menos ainda política e ambiental. Na sua visão, o que há é uma “maquiagem”. Criou-se um marketing do Acre de acordo com a lógica do capitalismo, mormente com as das agências financiadoras internacionais, e se faz crer à sociedade local que os problemas do Acre estão sendo resolvidos.

Há ainda, os que advogam a tese de que o extrativismo pode e deve ser inserido numa lógica de mercado. Os chamados economicistas. Esta corrente é representada pela atual Secretaria da Floresta.

Ressalta ainda Paula (2003, p. 244) que a idéia de a conservação da natureza não ser incompatível com a exploração para fins comerciais da biodiversidade potencial do Acre, desde que sustentada, exige por parte do Estado a instituição de políticas e subvenções especiais direcionadas para a preservação da paisagem natural e da herança cultural das populações tradicionais.

[. . .] ao “jogar o jogo” da mercantilização da natureza, o Estado [no sentido ampliado] corroborou ativamente para maximizar a apropriação privada do patrimônio natural. É preciso reverter esse jogo, combater esse 
pragmatismo exacerbado, que relegou, em grande parte aos "mercadores da natureza” o destino da conservação da paisagem natural na Amazônia.

Nessa perspectiva de "mudar o jogo da mercantilização" [frente] a necessidade de revalorizar a dimensão pública da conservação das florestas e de subordinar as relações mercadológicas a esse imperativo do interesse público para construir uma sustentabilidade de longo prazo. ${ }^{317}$

Outro aspecto considerado por Elder Paula, que nesse caso concordamos, é que o desenvolvimento da Amazônia não pode ser formulado desarticulado do desenvolvimento nacional como um todo. Que papel econômico cabe à Amazônia nos contextos nacional e mundial?

\begin{abstract}
Se os resultados da centralização governamental no período ditatorial foram trágicas - como revelam, entre outros elementos, as fraudes praticadas pela extinta SUDAM, a devastação de florestas, a grilagem de terras, os assassinatos de lideranças sindicais [que persistem até hoje] etc os efeitos da "descentralização político-administrativa" apoiada nas "virtudes do mercado" não oferecem perspectivas futuras mais alentadoras. [. . .] em que pese o inestimável valor de inúmeras experiências comunitárias de desenvolvimento em curso na Amazônia, parece muito difícil admitir a idéia de que comunidades no vasto território amazônico possam lograr êxitos duráveis ou "sustentáveis" no tempo. Os problemas da Amazônia [. . .] são tão complexos quanto sua biodiversidade e seus processos sociais. ${ }^{318}$
\end{abstract}

\title{
Como viabilizar o Acre?
}

Considerando que na região acreana o maior empregador é governo nas esferas municipal, estadual e federal, onde a pecuária extensiva representa parte significativa da renda do Estado e o comércio e as indústrias se constituem atividades incipientes, além da agricultura ser basicamente de subsistência, fazendo com que frente ao contexto econômico interno, o Acre seja um repassador de divisas para outros mercados.

Por outro lado, os projetos sustentáveis ainda são localizados e não traduzem grande impacto social e econômico.

${ }^{317}$ PAULA, Op. Cit. p. 244.

${ }^{318}$ PAULA, Op.Cit. p. 245. 
O cerne da questão da viabilidade do Acre passa, necessariamente, pela questão da possibilidade de integrá-lo os mercados nacionais e internacionais, nessa fase peculiar do capitalismo internacional.

Necessário se faz manter a exploração de madeira em escala comercial, porém de forma racional, bem como a manutenção do extrativismo da borracha natural e da castanha subsidiada, mas, também é fundamental o desenvolvimento de algumas indústrias não só para atender as demandas locais, como também para comercializar com outros mercados, além de manter a pecuária e incentivar a agricultura em moldes capitalista.

Evidente que há potencialidades na região que interessam ao mercado internacional, como as plantas medicinais e as essências florestais, porém estas, para serem exploradas comercialmente, exigem suporte tecnológico de ponta compatíveis com a terceira Revolução Industrial.

Diante da etapa atual de desenvolvimento do capitalismo em escala mundial, a sobrevivência do Acre implica o estabelecimento de uma economia moderna e diversificada, tendo o Estado a função de, através de políticas e instrumentos legais, coibir a devastação da floresta amazônica em percentuais que comprometam o ecossistema.

Nem a mercantilização da natureza por si só e à revelia dos interesses dos segmentos sociais subalternos que vêm garantindo à sobrevivência por meio da floresta e defendendo-a secularmente, na medida que seus modos de vida estão historicamente vinculados a esta, nem a simples capitulação à lógica de mercado, sem a devida promoção de uma qualidade de vida melhor para as populações tradicionais.

No momento atual, as políticas do governo estadual se “movem” entre as teses de neoextrativismo e as dos economicistas, que gozam de maior aceitação e são conceituados por Elder Paula de “mercadores da natureza”. 
No entanto, é essencial ressaltarmos que a instituição de um novo imaginário político do Acre como uma “terra que tem jeito” tem trazido resultados positivos no que se refere à respeitabilidade externa da região e à elevação da autoestima dos acreanos, que não se resignam às mazelas existentes, na firme esperança de que é possível viabilizar o Acre. 


\section{OS LABIRINTOS DAS INVENÇÕES DO ACRE (CONCLUSÃO)}

"Invenções do Acre - De Território a Estado - um olhar social” é um trabalho acadêmico que reconstitui os momentos históricos decisivos da Constituição do Acre, que de uma "terra de ninguém" disputada entre bolivianos, peruanos e o governo do Amazonas, tendo por "trás dos bastidores", a presença e os interesses do capital internacional, na sua etapa monopolista e imperialista, tornou-se espaço brasileiro com a pecularidade de ter desencadeado uma guerra de fonteira por limites nos cenários dos altos rios do Aquiri (Acre), não só para integrasse ao Brasil, como também estabelecer sua conformação geográfica que, até o presente, não está totalmente concluída, na medida que, através de um proceso encaminhado ao Supremo Tribunal Fderal, o governo do Acre reivindica que o Amazonas devolva $1.000 \mathrm{Km}^{2}$ ao Acre, possibilitando o estabelecimento de uma nova linha Cunha Gomes.

Tem também a peculiaridade de ter sido País antes de ser Estado e experienciado a condição política de República antes da proclamação da República brasileira e, ainda, como parte da luta empreendida para integrar o território brasileiro ter pleiteado a condição de Estado, só alcançada, posteriormente, como resultado do confronto entre o poder da União e a afirmação do poder político local, por meio do Movimento Autonomista, que se sagrou vitorioso em 15 de juho de 1962, com a assinatura da Lei 4.070, pelo presidente João Goulart.

Também apresenta a singularidade de, durante a Segunda Guerra Mundial, por pressão política e ideológica dos E.U.A., ter desencadeado a chamada "Batalha da Borracha", quando soldados-seringueiros inseridos na imensidão da floresta tiveram que produzir incessantemente borracha para atender o esforço de guerra, contribuindo, sobremaneira, para a vitória dos Países Aliados. 
Outro aspecto que denota o caráter peculiar do processo histórico acreano é o fato de a “Revolução Cultural” ter ocorrido em pleno período político de exceção na década de 1970, quando a música, o teatro, o cinema, a literatura e a imprensa alternativa se tornaram veículos de expressão política contra o regime militar, o processo de expropriação dos seringueiros, e dos povos indígenas e a devastação da Amazônia através de movimentos organizados que contaram com a participação do Diretório Central dos Estudantes da UFAC, Centro de Defesa de Direitos Humanos da Diocese de Rio Branco, OAB-AC, Comunidades Eclesiais de Base, Fundação Cultural do Estado do Acre, partidos políticos de esquerda e os sindicatos de trabalhadores rurais, citando os de maior capacidade organizativa e luta política.

O estudo desenvolvido centrado no tema, como o Acre tornou-se Estado e vem sendo inserido nos contextos nacional e internacional possibilitou a reconstituição histórica das invenções do Acre tanto numa perspectiva diacrônica quanto sincrônica.

Diacrônica porque fundamenta-se na Constituição do Acre como processo, mas, ao mesmo tempo, buscou-se particularizar cada período inventivo demarcando historicamente cada invenção do Acre.

Assim, a marca da invenção do Acre estrangeiro liga-se à disputa por domínio de terras na América envolvendo Portugal e a Espanha, numa espécie de "dança" das linhas territoriais nos quadros do velho colonialismo europeu.

Por sua vez, a particularidade da invenção do Acre brasileiro consistiu nos conflitos de fronteira envolvendo o Brasil, a Bolívia e o Peru no contexto de dominação do capital monopolista e imperialista, a invenção do Acre emancipado foi tecida no confronto entre o poder local e o poder nacional, desde as primeiras décadas do século XX até princípio dos anos 60, através do Movimento Autonomista, que, ao longo desse período, adotou estratégias diferenciadas de luta. 
Ao passo que, a invenção do Acre viável está em processo e foi desencadeada pela resistência ao projeto de "modernização" centrado na grande propriedade fundiária e na pecuária de corte, tal como previsto inicialmente para a região, sendo bloqueado politicamente, pela luta liderada pelos extrativistas e seus aliados, e, no estágio atual, caracteriza-se por um tipo de ordenamento da posse e uso da terra que assegure a coexistência de grandes propriedades que exploram a pecuária extrativa de corte, minifúndios que se especializam em formas mistas de exploração - agricultura e pecuária - e as áreas reservadas ao extrativismo, que vêm se desenvolvendo na perspectiva de constituir uma produção centrada no agroextrativismo, num grau ainda caracterizado pela indefinição e num contexto nacional e internacional ditado pela lógica capitalista, pela supremacia do mercado.

Do ponto de vista metodológico, a meta almejada foi possibilitar o diálogo entre as várias invenções do Acre, num viés teórico em que a argumentação construída reflete a teoria na reconstituição histórica de cada invenção.

A opção teórica se insere no contexto das tendências contemporâneas da historiografia, na medida que a história é reconstituída sem determinações e compartimentações, ao mesmo tempo que a teoria não é vista como modelos conceituais expostos em longas digressões. A teoria está diluída no texto e se expressa na interpretação de cada momento inventivo.

Por sua vez, os processos sociais e econômicos abordados são apresentados em sua indeterminação, abertos a soluções inesperadas para romper a rigidez das explicações lineares.

Por fim, é um texto que trabalha as invenções do Acre trazendo para a cena histórica os atores sociais das invenções do Acre, com suas pegadas, vozes, idéias, projetos, contradições. . . num processo histórico marcado pela resistência.

Resistentes foram os migrantes nacionais e estrangeiros e, nestes últimos, destacam-se os sírios e libaneses, que adentraram um território desconhecido, cujo imaginário veiculado 
pelo Estado brasileiro e as elites nacionais era descrito como "selva amazônica", os quais, dominando o meio físico, lançaram as bases da sociedade extrativista.

Da seringueira, árvore-mãe do Acre e dos acreanos, cujo leite transformado em borracha foi alvo da cobiça internacional num momento específico do capital industrial e financeiro, constituiu-se num povo múltiplo étnico e socialmente que dominou e nominou a natureza, dela extraindo o próprio sustento, e, nutridos pela mãe-natureza, vêm tentando construir no chão da Amazônia Sul Ocidental um modelo de desenvolvimento não excludente em relação às populações tradicionais - índios, seringueiros, ribeirinhos, trabalhadores rurais. . que tanto pela historiografia tradicional quanto pelo modelo de desenvolvimento imposto à região, de cima para baixo, foram "silenciados", "apagados", como se o Acre fosse um imenso vazio.

Este povo, marcado pela resistência física necessária para sobreviver inserido no meio da floresta destituído dos equipamentos essenciais à preservação e reprodução da vida, teve que fazer-se a si mesmo.

Resistentes têm sido os migrantes, com ênfase para os nordestinos, e, entre eles, os cearenses, que, juntando-se aos imigrantes estrangeiros, e numa fase mais recente aos migrantes do Sul e Sudeste, os quais na condição de deserdados vieram "fazer o Acre" , lembrando os que foram "fazer a América".

Resistentes foram quando, na condição de "soldados-seringueiros", contribuíram para a derrota da barbárie nazi-fascista.

Resistentes também foram aqueles que se rebelaram contra o mandonismo dos patrões-seringalistas e os que debandaram do regimento de "soldado da borracha" frente às condições impostas.

Resistentes também são aqueles que lutaram contra o arbítrio político local e nacional. 
Resistentes são pela capacidade de sonhar diante das adversidades com que se defrontam.

Resistentes são os que, na atualidade, acreditam e apostam numa revolução científica e tecnológica aplicada ao modo de vida extrativista agregando valor aos produtos da região.

Nesse sentido, o texto produzido não é marcado pela objetividade histórica preconizada pelos historiadores positivistas, mas pelo diálogo entre objetividade e subjetividade, na perspectiva de fazer com que os atores sociais das invenções do Acre apareçam com suas idéias, vozes, sonhos, acordos e desacordos, atos de heroísmo e covardia, suas contradições e seus acertos. . .

Não é uma história de vencidos e menos ainda dos vencedores, tampouco dos de baixo contrapondo-se aos de cima, mas a tentativa da escrita da história na qual a multiplicidade dos sujeitos históricos aparece na sua complexidade no campo de possibilidade que é o território da história.

No entanto, ao expressar o custo social das invenções do Acre, evidenciamos que os setores subalternos vêm pagando um preço maior.

A total imparcialidade não existe, a história é vivida e escrita por seres humanos que se posicionam, que tomam partido, mormente sendo um texto escrito por uma migrante mulher, nordestina e negra.

Destacamos ainda, para os que acharem o texto longo, fazendo uso das palavras de Hannah Arendt, "tudo que é curto demais se torna dogmático".

E, inserindo-me nesta "terra da promissão" que tem sido o Acre no imaginário dos migrantes, ouso dizer: 
Como será a escureza

Desse mato virgem do Acre?

Como serão os aromas

A macieza ou aspereza

Desse chão que também é meu?

Mário de Andrade, 1924 


\section{REFERÊNCIAS BIBLIOGRÁFICAS}

Monografia em Geral ( considerada no todo ou em parte)

ACHA, José Aguirre. De los Andes al Amazonas. La Paz: [s.n.], 1980.

ALMEIDA, Fernando H. Mendes (Org.). Constituições do Brasil. São Paulo: Saraiva, 1954.

ALVES PINTO, Nelson Prado. Política da borracha no Brasil: a falência da borracha vegetal. São Paulo: HUCITEC, 1984.

ANDRADE, Manoel Correia de. Geopolítica do Brasil. 2.ed. São Paulo: Ática, 1993.

BAEZKO, Brovislaw. Imaginação social. In: . ENCICLOPÉDIA Einaudi.

Portugal: Nacional / Casa da Moeda, 1985,

BENCHIMOL, Samuel. A Amazônia: um pouco antes e além depois. Manaus: Umberto Calderaro, 1977.

BENEVIDES, Maria Victoria de Mesquita. O governo Kubitschek: desenvolvimento econômico e estabilidade política - 1956-1961. Rio de Janeiro: Paz e terra, 1976.

BOBBIO, In: DELGADO, Lucília de Almeida Neves. História oral e narrativa: tempo, memória e identidades. História oral. Revista da Associação Brasileira de História Oral. São Paulo, 2003.

BOSI, Ecléa. Memória e sociedade: lembranças de velhos. São Paulo: Companhia das Letras, 1994.

CALIXTO, Valdir de Oliveira. Plácido de Castro e a construção da ordem no Aquiri (contribuições à história das idéias políticas). Rio Branco: Governo do Estado do Acre/ Fundação Elias Mansour, 2003.

CAPELATO, Maria Helena Rolim; PRADO, Lígia Coelho. A borracha na economia brasileira da primeira República. In: . História Geral da Civilização, São Paulo:

Difel, 1975, v.3.

CARDOSO, Fernando Henrique, MULLER, Geraldo. Amazônia - expansão do capitalismo. São Paulo: Brasiliense, 1977.

CARNEIRO, Hugo Ribeiro. Relatório apresentado ao Exmo. Sr. Dr. Augusto de Viana Castelo, relativo ao período de janeiro de 1928 a outubro de 1929. Rio de Janeiro: Imprensa nacional, 1930.

CARVALHO, José A primeira insurreição acreana.(documentada). Pará: Gilelet, 1904./ 
CASTRO, Genesco. O Estado Independente do Acre. Rio de Janeiro: [s.n], 1930.

CASTORIADIS, Cornélius. La institución imaginaria de la sociedad. In: . El imaginario social. Montevedel: Altamira, 1993.

CHACON, Vamireh. História dos partidos políticos. Brasília: Unb, 1981. Abramo, 2004. Brasil - mito fundador e sociedade autoritária. São Paulo: Fundação Perseu

CHAUÍ, Marilena. Conformismo e resistência: aspectos da cultura popular no Brasil. São Paulo: Brasiliense, 1996.

COGGIOLA, Osvaldo. O capital contra a história - gênese e estrutura da crise contemporânea. São Paulo: Pulsar, 2002.

COSTA, Homero de Oliveira. Os partidos políticos no Acre (1945-78). Rio Branco:

UFAC, 1992. (Cadernos da UFAC. Série Estudos Sociais).

COSTA SOBRINHO, Pedro Vicente. Capital e trabalho na Amazônia. São Paulo:Cortez Rio Branco:UFAC, 1992.

. Comunicação alternativa e movimentos sociais na Amazônia Ocidental. João Pessoa: Universitária/ UFPB, 2001.

COSTA, João Craveiro. A conquista do deserto ocidental: subsídios para a história do Território do Acre. 2.ed. São Paulo: Nacional, Brasília: INL, 1973.

CUNHA, Euclides. A margem da história. São Paulo: Marins Fontes, 1999.

DANTAS FILHO, José; DORATIOTO, Francisco Fernando Monteoliva. A república bossanova. A democracia populista ( 1954-1964). 3.ed. São Paulo: Atual, 1991.

DUARTE, Elio Garcia. Conflitos pela terra no Acre: a resistência dos seringueiros de Xapuri. Rio Branco: Casa da Amazônia, 1987.

EPOPÉIA ACREANA( 1902-1903). Cinquentenário do tratado de Petrópolis: homenagem do Sistema Estatístico regional. Rio Branco: [s.n.], 1953.

ESTEVES, Florentina. Enredos da memória. Rio de Janeiro: Oficina do Livro, 1990.

FLORES, Hilda Agnes, HÜBNER, Moacir. Rio Grande do Sul: aspectos da revolução de 1893. Porto Alegre: Martins Livreiro, 1999.

FONSECA, Cassio. A economia da borracha: aspectos internacionais e defesa da produção brasileira. Rio de Janeiro: SUDHEVEA, 1970.

FOUCAULT, Michel. Microfísica do poder. 9.ed. Rio de Janeiro: Global, 1989.

. Vigiar e punir. História da violência nas prisões. Petrópolis: Vozes, 1987. 
A ordem do discurso. São Paulo: Loyola. 1999.

GUERRA, Antonio Teixeira. Estudo geográfico do território do Acre. Rio de Janeiro: IBGE, 1955.

IANNI, Octávio. A luta pela terra: história social da terra e da luta pela terra numa área da Amazônia. Petrópolis: Vozes, 1978.

KALUME, Jorge. Elevação do Território do Acre. Brasília: Senado Federal, 1985. (coletânea de documentos).

HOBSBAWM, Eric; RANGER, Terence. A invenção das tradições. Rio de Janeiro: Paz e terra, 1997.

JAGUARIBE, Hélio. A renúncia do Presidente Quadros e a crise política. Revista Brasileira de Ciências Sociais. nov. 1961.

JANOTTI, Maria de Lourdes Mônaco. Subversivos da república. São Paulo: Brasília, 1986.

MARTIM, André Roberto. Fronteira e nações. São Paulo: Contexto, 1992.

ORLANDI, Eni Puccinelli. Análise de discurso: princípios e procedimentos. Campinas: UNICAMP, 1997. 1997.

As formas do silêncio: no movimento dos sentidos. 4.ed. Campinas: UNICAMP,

OLIVEIRA, Lúcia Lippi. A questão nacional na primeira república. São Paulo: Brasiliense, 1990.

PESSOA, Enock da Silva. Trabalhadores da floresta do alto Juruá: cultura e cidadania na Amazônia. Rio Branco: EDUFAC, 2004.

PORTELLI, Hugues. Gramsci e o bloco histórico. Rio de Janeiro: Paz e Terra, 1977..

QUEIROZ, Maria Isaura Pereira de. O mandonismo local na vida política brasileira e outros estudos. São Paulo: Alfa-Ômega, 1976.

QUEIROZ, Suely Robles Reis de. Os radicais da república: Jacobinos, ideologia e ação. São Paulo: Brasiliense, 1996.

RANCY, Cleusa Maria Damo. Raízes do Acre ( 1870-1912). Rio Branco: SEEA, 1980.

REGO, José Fernandes. Estado e políticas públicas: a reocupação econômica da Amazônia durante o regime militar. São Luís: EDUFMA/ Rio Branco: UFAC, 2002.

REIS, Arthur César. A Amazônia e a cobiça internacional. Rio de Janeiro: Civilização Brasileira, 1982. 
. O seringal e o seringueiro. Rio de Janeiro: Serviço de Informação Agrícola, 1953. (documentário da vida real)

SANTANA, João Crescêncio de. Janela do tempo - registro histórico: José Guiomard dos Santos. No prelo

SANT ‘ANA JÚNIOR, Horácio Antunes. Florestania: a saga acreana e os povos da floresta. Rio Branco: EDUFAC, 2004.

SANTOS, Roberto Araújo de Oliveira. História econômica da Amazônia (1880-1970). São Paulo: T.A. Queiroz, 1980.

SILVA, Adalberto Ferreira da. Raízes da ocupação recente das terras no Acre: transferência de capitais e disputa pela terra. Rio Branco: Governo do Estado do Acre, 1986.

SILVA, Maria do Perpétuo Socorro et al. Seringueiro: memória, história e identidade. Rio Branco: UFAC/DH, 1996, v.2

SKIDMORE, Thmoas. Brasil de Castelo a Tancredo. 1964-1985. Rio de Janeiro: Paz e terra, 1988.

SOUZA, Carlos Alberto Alves. História do Acre: novos temas, nova abordagem. Rio Branco: Carlos Alberto Alves de Souza Ed., 2002.

THOMPSON, E. P. O termo ausente: experiência In:

. A miséria da teoria ou um planetário de erros - uma crítica ao pensamento de Althusser. Rio de Janeiro: Zahar, 1981. p.180-201.

TOCANTINS, Leandro. O rio comanda a vida: uma interpretação da Amazônia. 4.Ed. Rio de Janeiro: Americana, 1972.

VOVELLE, Michel. Jacobinos e jacobinismo. São Paulo: EDUSC, 2000.

WOLFF, Cristina Scheibe. Mulheres da floresta - uma história. Alto Juruá, Acre (18901945). São Paulo: Hucitec, 1999.

\subsection{Dissertações}

BEZERRA, Maria José. A invenção da cidade: a modernização de Rio Branco durante a gestão do governo Guiomard Santos 1946-50. Recife: UFPE, 2002.

COSTA, Francisco Pereira da. Seringueiro, patrões e a justiça no Acre Federal, 1904/1918. Recife: UFPE, 2002.

LIMA, Manoel Ferreira. A Bolívia de 1880 a 1905: nas relações exteriores e a questão do Acre. Niterói: UFF, 1991.

MOURÃO, Nilson Moura Leite. A prática educativa das CEBs: popular e transformadora ou clerical e conservadora? São Paulo: PUC-SP, 1988. 
OLIVEIRA, Luiz Antonio Pinto de. O sertanejo, o brabo e o posseiro (cem anos de andanças da população acreana). Belo Horizonte: UFMG, 1982.

1.3 Teses

BASILIO, Sandra, Tereza Cadiolli. A Igreja e a luta pela terra no Acre. Recife: UFPE, 2000 .

CALIXTO, Valdir de Oliveira. Aquiri (1898-1900) Os patrões e a construção da ordem. São Paulo: USP, 1993.

CARVALHO, Lucas Araújo. Colonização e meio ambiente: estudo de duas experiências de assentamento na Amazônia Ocidental. São Paulo: Campinas, 2000.

CAVAlCANTI, Francisco Carlos da Silveira. A política ambiental na Amazônia: um estudo sobre as reservas extrativistas. Campinas, SP: UNICAMP, 2002.

MARTINELLO, Pedro. A batalha da borracha na Segunda guerra mundial e suas conseqüências para o vale amazônico. São Paulo: USP, 1985.

PAULA, Elder Andrade de. Estado e desenvolvimento insustentável na Amazônia Ocidental: dos missionários do progresso aos mercadores da natureza. Rio de Janeiro: UFRRJ, 2003.

$2 \quad$ Publicações periódicas

2.1 Artigos e/ou matéria de jornal

A BANCADA pessedista a favor do Estado do Acre. O Estado. Rio Branco, 6 ago. 1959. 9 recorte)

À MARGEM da III Conferência econômica da borracha- palestra pronunciada ao microfone da ZYD-9 pelo Dr. Valério Caldas de Magalhães: O Acre. Rio Branco, nov. de 1949. ( recorte)

APROVAÇÃO do projeto do Estado do Acre na Comissão de Finanças retempera o entusiasmo dos acreanos. O Acre. Rio Branco, 13 abr. 1960. ( recorte)

ASPIRAÇÕES autonomistas. O Estado. Rio Branco, s.d.

AUTONOMIA do Acre. O Juruá. Cruzeiro do Sul-AC, 3 mar.1957. (recorte)

CÂMARA federal aprova o projeto do Estado do Acre. O Estado. Rio Branco, 30 out. 1960, p.1.

CARTA- questionário a um anti-autonomista. O Acre. Rio Branco, 28 ago. 1958. ( recorte)

DEPUTADO Oscar Passos discursa na Câmara: Estado do Acre. O Acre. Rio Branco, 15 dez. 1960. ( recorte) 
ELEITO pela vontade soberana do povo o prof. José Augusto de Araújo. O Acre. Rio Branco, 20 out. 1962. ( recorte)

ESPÏRITO bandeirante paulista deve interessar-se pelo Estado do Acre. O Estado. Rio Branco, 8 dez. 1962, p.1.

ESTADO do Acre marcha para a vitória. O Estado. Rio Branco, 4 abr. 1959. ( recorte)

ESTADO do Acre: nossa esperança. O Estado. Rio Branco, s.d. (recorte)

ESTADO do Acre: uma realidade. O Estado. Rio Branco, 16 abr. 1960. (recorte)

INCORPORARAM o Acre ao Brasil mantendo a mesma forma de governo em que vivia. $\mathbf{O}$ Estado. Rio Branco, 19 set. 1959.(recorte)

LEI do Estado do Acre. O Acre. Rio Branco, 21 jul. 1962. (recorte)

MESQUITA, Geraldo. O Acre. Rio Branco, 17 mar.1957. (recorte)

O ACRE progride. O Acre. Rio Branco, 6 ago. 1960 ( recorte)

O PSD mantém sua posição de majoritário. Guiomard o deputado mais votado. O Estado. Rio Branco, 10 out. 1958. (recorte)

O 7 de setembro na Capital Acreana. O Acre. Rio Branco, 13 set. 1958. ( recorte)

PLANO de salvação para o Acre. O Estado. Rio Branco, 8 dez. 1964, p.1.

PRESIDENTE Jango transforma o Acre em Estado. O Estado. Rio Branco. S.d. ( recorte).

PROF. José Augusto recebido festivamente veio assistir à instalação da Constituinte. O Estado. Rio Branco, 22 dez. 1962, p. 1.

PROJETO elevando o Acre a Estado é prematuro e inconstitucional. O Acre. Rio Branco, 16 jul. 1961. ( recorte)

VAMOS plantar seringueira. O Acre. Rio Branco, 12 abr. 1958. ( recorte)

VITAL, Raimundo Sales. Exortação cívica. O Acre. Rio Branco, 19 maio 1957. ( recorte)

3 Documentos pessoais, oficiais e jurídicos

ACRE (estado). Secretaria de Intendência Municipal de Rio Branco. Código de Posturas Municipais: lei no 159. Rio Branco. 1929

ATA da $22^{\mathrm{a}}$ sessão da Junta revolucionária do Acre. IAHP.

ACTA da sessão Extraordinária da Independência do Acre. 7 ago. 1902.

BESOURO, Gabino. Relatório apresentado ao Exmo. Sr. Ministro do Interior, Dr. Augusto Tavares de Lyra. Vila Rio Branco: Departamento do Alto Acre, 1909. 
BEZERRA, Maria José (Org.). Dossiê- Acervo: Guiomard Santos ( Acre), elevação do Acre a estado. Rio Branco: Globo, 1992.

UFAC, 1999.

(Org.). Documenta Galvez. O Estado Independente do Acre. Rio Branco:

CARNEIRO, Hugo Ribeiro. Relatório apresentado ao Exmo. Sr. Dr. Augusto de Viana Castelo, relativo ao período de janeiro de 1928 a outubro de 1929. Rio de Janeiro: Imprensa Nacional, 1930.

CASTRO, José Plácido de. Relatório apresentado ao Exmo. Sr. Dr. Augusto Tavares de Lyra., D.D. Ministro da Justiça, por José Plácido de Castro, Prefeito Interino ( 19061907). [s.1.:s.n.].

DEPARTAMENTO DO PATRIMÔNIO HISTÓRICO DA FUNDAÇÃO ELIAS MANSOUR. Relação dos prefeitos dos departamentos do Acre e governadores do AcreTerritório e Acre-Estado. Rio Branco, 1999.

GOVERNO DO ESTADO DO ACRE. Ação cível originária demarcatória contra os Estados de Rondônia e Amazonas no 415-2. Supremo Tribunal Federal. Brasília, 1996.

JACOME, Epaminondas. Relatório enviado ao Exmo. Sr. Ministro da Justiça e Negócios Interiores.Cidade de Empreza, 1911.

KALUME, Jorge ( Org.). Elevação do Território do Acre. Brasília: Senado federal, 1985 (Coletânea de documentos).

MAGAlHÃES, Valério Caldas de. Relatório do Departamento de Produção. Rio Branco: Governo do Território federal do Acre, 1951.

MATTOS, Raphael Augusto da Cunha. Relatório apresentado ao Exmo. Sr. Dr. José Joaquim Seabra, Digno Ministro da Justiça e negócios Interiores pelo Coronel de Arma de Infantaria Raphael Augusto da Cunha Mattos (20.01.1904).Villa Rio Branco: Prefeitura do Alto Acre, 1904.

MESQUITA JÚNIOR, Geraldo ( Org.). O Tratado de Petrópolis e o Congresso Nacional. Brasília: Senado Federal, 2003 (Coleção documentos para a história do Acre).

MODUS Vivendi, assinado entre o Ministro Sr Dr. Eliodoro Villazón e o Sr Eduardo Lisboa enviado ao Ministro extraordinário dos Estados Unidos do Brasil. Arquivo Histórico do Itamarati, AHI..

PARAVICINI, José. Relatório apresentado ao supremo governo sobre a dupla missão que desempenhou de Ministro Plenpotenciário no Brasil e delegado Nacional nos territórios do Acre. Petropólis: Type. De Pap. Jeronymo, 1900.

SANTOS, José Guiomard dos. Carta ao velho Cintra. Rio Branco: Território Federal do Acre, 1946. 
. Discurso proferido na sessão da Câmara Federal, em 17 de novembro de 1953, em nome da maioria. In: BEZERRA, M. J. (org.). Dossiê-Acervo: Guiomard Santos(Acre) Elevação do Acre a Estado. Rio Branco:Globo, 1992.

Discurso-programa. Rio Branco: Território Federal do Acre, 1946.

. Relatório da Administração do Território federal do Acre no exercício de 1949 (janeiro a setembro). Rio Branco: [s.n.], 1949.

- Relatório apresentado ao Exmo. Sr. General Eurico Gaspar Dutra, D.D. Presidente da República, pelo Major José Guiomard dos Santos, Governador delegado da União no Território Federal do Acre, referente às atividades de administração acreana no exercício de 1946. Rio Branco: [s.n.], 1946.

. Projeto de Lei Especial. In: BEZERRA, Maria José (org.). Dossiê-Acervo: Guiomard Santos (Acre) Elevação do Acre a estado. Rio Branco: Globo, 1992.

. Projeto de elevação do Acre a estado ( versão de 1957). In: BEZERRA, Maria José. Dossiê-Acervo: Guiomard Santos(Acre) Elevação do Acre a Estado. Rio Branco: Globo, 1992..

. Diário do Congresso Nacional, 14 abr. 1961.

SILVA, João Mariano da. Carta ao Guiomard Santos. 3 mar. 1957.

SOUZA, Deocleciano Coelho de. Relatório do Prefeito interino do Departamento do Alto Acre, Dr. Deocleciano Coelho de Souza. Penapólis: Departamento do Alto Acre, 1910. TRATADO Velarde - Rio Branco e informacion complementario ( Rio de Janeiro, 8 de setembro de 1909). Puerto Maldonado: Sub Regional de Educación / Madre de Dios, abril de 1996.

$4 \quad$ Entrevistas

ALENCAR, João Moreira (Sr. João Borborema): depoimento [19 out. 2004]. Entrevistadora: Maria José Bezerra. Rio Branco.

ARAUJO, Maria Lúcia de: depoimento [11 jun. 1996]. Entrevistadora: Maria José Bezerra, Rio Branco.

ISPER, Alegria Abdala: depoimento [18 jun. 1996]. Entrevistadora: Maria José Bezerra. Rio Branco.

JARDIM, Foch: depoimento [23 set. 1996]. Entrevistadora: Maria José Bezerra, Rio Branco.

KOURY, Hélio César: depoimento [01 out. 2004]. Entrevistadora: Maria José Bezerra. Rio Branco.

MACÊDO, Joaquim Falcão: depoimento [25 abr. 1996]. Entrevistadora: Maria José Bezerra. Rio Branco. 
MANSOUR, Francisco Eduardo Pinheiro: depoimento [15 jul 1996] Entrevistadora: Maria José Bezerra, Rio Branco.

MESQUITA, Geraldo: depoimento [16 maio 1996] Entrevistadora: Maria José Bezerra. Rio Branco.

MORAIS, Geraldo Alves: depoimento [1977]. Entrevista realizada pela equipe de pesquisadores do Projeto "Seringueiro- memória, história e identidade". Rio Branco.

MUNIZ, Cizinho: depoimento.[1977] . Entrevista realizada pela equipe de pesquisadores do Projeto "Seringueiro: memória, história e identidade. Rio Branco.

NEVES, Wild Viana das: depoimento [09 jul. 1996]. Entrevistadora: Maria José Bezerra. Rio Branco.

NOBRE, Cláudio: depoimento [11 nov. 1996]. Entrevistadora: Maria José Bezerra. Rio Branco.

PAES, Ana Carneiro (D. Inglesinha): depoimento [19 abr. 1996]. Entrevistadora: Maria José Bezerra. Rio Branco.

PAULA, Elder Andrade de: depoimento [11 ago. 2004] Entrevistadora: Maria José Bezerra, Rio Branco.

PAULA, Omar Sabino de: depoimento [23 maio 1996]. Entrevistadora: Maria José Bezerra. Rio Branco.

REGO, José Fernandes do: depoimento [30 jul. 2004] Entrevistadora: Maria José Bezerra, Rio Branco.

SANTOS, Lydia Hammes Guiomard: depoimento [8 maio 1996]. Entrevistadora: Maria José Bezerra. Rio Branco.

SILVA, Anibal Miranda Ferreira da: depoimento [3 jul. 1996]. Entrevistadora: Maria José Bezerra. Rio Branco.

THAUMATURGO, Francisco: depoimento [4 jun. 1996]. Entrevistadora: Maria José Bezerra. Rio Branco.

ZANINNI, Íris Célia Cabanellas: depoimento [10 junho 1996]. Entrevistadora: Maria José Bezerra. Rio Branco. : depoimento [1 jul. 2004]. Entrevistadora: Maria José Bezerra. Rio Branco. 


\section{GLOSSÁRIO}

Acordos de Washington - conjunto de Acordos/ convênios firmados entre os E.U.A. resultante da III Conferência dos Chanceleres americanos realizada no Rio de Janeiro, em janeiro de 1942 para viabilizar a realização da "batalha da borracha" na Segunda Guerra Mundial assinados pelos Ministros Souza Costa e o Subsecretário de Estado dos E.U. A., Summer Welles e que implicou na criação de vários órgãos nacionais e internacionais que consorciados criaram as bases para a produção de Borracha no Acre para atender o esforço de guerra. Por este Acordo os Estados Unidos aplicariam capital para reativar os seringais e comprar a produção do látex brasileiro por um período de 5(cinco) anos de 1942 a 1947.

Arigó - expressão utilizada para designar o migrante nordestino que chegava à Amazônia

Aquiri - termo indígena, cuja corruptela deu origem ao nome Acre.

Autonomia - termo designado para denominar a luta pela emancipação política do Acre, na medida que, enquanto Território, o Acre se constituía numa região tutelada pelo governo federal.

Banco de Crédito da Borracha- criado em 9 de junho de 1942, atualmente denomina-se Banco da Amazônia S.A.. Tinha a função de financiar e comprar a borracha produzida nos seringais acreanos.

Barracão - símbolo da sede do seringal, que constituía a resid6encia do seringalista e de seus auxiliares diretos. Em muitos casos, concentrava-se num mesmo barracão também o armazém geral. 
Birô Interamericano - espécie de Conselho criado para coordenar o processo de inserção do Brasil na Batalha da Borracha durante a Segunda Guerra Mundial.

Bolivian Syndicate - criado em 11 de junho de 1901 localizava-se em New York e exercia administração fiscal do território do Acre, podendo cobrar toda espécie de imposto, direitos alfandegários e usufruir rendas das terras, conforme as leis bolivianas. Foi instituído através de um Acordo firmado entre Félix Aramayo ( Bolívia) e Frederich Wilinfred Whitridge, da empresa Car Whitridge. Por meio deste instrumento $60 \%$ dos lucros com a borracha ficavam para a Bolívia e 40\% para o Bolivian Syndicate. Também através deste consórcio, a Bolívia concedia ao Bolivian Syndicate o direito de arrecadar qualquer tipo de imposto na região do Acre, além do direito de navegar livre e tranquilamente pelos rios acreanos, bem como fazer uso da força, se necessário, para manter seus direitos e privilégios. Possibilitava ainda que, após um ano de vig6encia, o Bolivian Syndicate poderia estudar os meios para ligar os rios do Acre aos rios bolivianos Orton e Madre de Dios por estradas de ferro.

Brabo - termo que designa o migrante nordestino assim que este chegava no seringal e a medida que este adaptava-se ao novo modo de vida na floresta transformava-se em manso..

Cadeia de dependência - era o elo que unia seringueiro-seringalista-casas aviadoras-casas exportadoras. A borracha era a mercadoria na cadeia de aviamento e matéria-prima nas indústrias internacionais.

Casas aviadoras - eram as casas de comércio localizadas em Belém e Manaus que abasteciam os seringais do Acre. 
Casas exportadoras - eram as responsáveis pela exportação da borracha para os mercados exteriores através de Companhias como : Hamburg Amerika-Line, Lloyde Brasileiro, The Amazon Stenm Navegation Co. Ltda, Liguré Brasiliana, Boat S.S.C. e a Read Cross Line. Ficavam localizadas em Belém e Manaus.

CAETA - Comissão Administrativa de Encaminhamento de Trabalhadores para a Amazônia, que substituiu o SEMTA ( Serviço de Mobilização dos Trabalhadores para a Amazônia) trazia os nordestinos até Belém e os entregava a SAVA para alimentá - los e encaminhá-los aos seringais.Criada em 14 de setembro de 1945 ficava sobordinada a CCAW ( Comissão de Controle dos Acordos de Washington).

Chatas, chatinhas - embarcação a vapor, movida por roda a popa. O nome vem do formato do casco-chato- para melhor vencer os baixios e os paus nos altos rios da Amazônia.

Coronel de barranco- expressão que de um lado tem suas origens na Guarda Nacional e do outro no fato de que a maioria dos seringais foram criados a margem dos rios. Daí o uso "coronel de beira de rio".

Colocação de seringa - é a área do seringal onde o seringueiro mora.

Coronel de barranco - expressão que de um lado tem suas origens na Guarda Nacional e do outro no fato de que a maioria dos seringais foram criados a margem dos rios. Daí o uso "coronel de beira de rio".

Defumar - processo rotineiro de preparar a borracha, coagulando a leite da seringueira, por meio da fumaça de cavacos de madeira ou de certos cocos, como jaci, ouricuri e outros. 
Desobrigas - visitas que os padres faziam periodicamente aos seringais e nas quais ministravam os sacramentos da Igreja Católica, como batizados e casamentos coletivos. Durante ou após as desobrigas, ocorriam as festividades para as comemorações das “cerimônias" realizadas.

Empate - estratégia de luta criada pelos seringueiros para empatar, ou seja, impedir a derrubada da árvore da seringueira.

Estrada de seringa - termo que designa a abertura de trilha na floresta pelo seringueiro para facilitar a coleta do látex da seringueira.

Goma elástica - bola resultante da coagulação do leite da seringueira e que no Acre pesava, geralmente, em média 50 quilos,

Igapó - pântano formado pelo extravasamento dos rios. A água fica presa durante o verão.

Igarapé - afluente menor de um rio, tipo de riacho amazônico que facilita e oferece as condições necessárias para a 1;ocomoção diária dos interioranos na floresta.

Jacobinistas - o termo refere-se ao jacobinismo, como decorrente da transição dos jacobinos ao jacobinismo. Independente dos conceitos, os jacobinistas se consideram herdeiros da França de 1793, cuja prática política sofreu peculiaridades históricas em cada região onde se desenvolveu. No sentido geral, destaca Michel Vovelle, caracterizam-se por um republicanismo que se apresentava como radical, uma intransigência sem concessões, cuja afirmação do Estado era a base, com o risco de que com esta atitude esvaziada do seu 
conteúdo inicial, viesse a se tornar uma afetação, uma postura, às vezes, uma máscara: simplificando seria a última trajetória do radicalismo francês, bem como do partido de ação italiano, das últimas décadas do século às primeiras décadas do século XX. Por fim aconteceram migrações, captações, quando pelo menos parte do movimento operário de Jaurés a Lênin, uniria esta referência a novas experiências, em um quadro ideológico renovado pelo marxismo. Para Lênin, ser comunista era ser jacobino com o povo. No seu caráter transhistórico, o jacobinismo marcou tanto a direita quanto a esquerda dos movimentos políticos do século XX.

Jacobinos - a expressão "jacobino" e a carga de significação que a mesma tem, segundo Michel Vovelle, remete ao convento dominicano dos jacobinos, onde por mero acaso, o Clube de Paris se instalou. E foram os monarcas da Prússia e da Rússia que tornaram o termo sinônimo de radicalidade e subversão, ao rotularem os ativistas [polonmeses, como operários de uma "fábrica de jacobinos". Enfatiza, ainda, este autor que suas origens estão relacionadas as redes de confrarias de devoção, profanas ou devotas, a exemplo das caridades ou das irmandades maçônicas, das quais o jacobinismo é certamente tributário, assim como é das sociedades de pensamento, mas em relação as quais guarda uma diferença essencial, a de ter realizado a "passagem a política real de formas de democracia inédita". Destaca-se, também, que os jacobinos tiveram durante a Revolução Francesa grande atuação, mormente na fase do Terror, encarnada na figura de Robespierre.

Legionárias - o termo é derivado da legião Autonomista, uma das mais antigas agremiações dedicada a luta pela emancipação política do Acre e caracterizará a participação da mulher acreana em grupos organizados em todo o território do Acre, com ênfase em Rio Branco, os quais atuavam através dos partidos políticos PSD e PTB. 
Manso - léxico utilizado para designar o migrante nordestino "domado".

Marreteiro - comerciante que a altos preços fornece aos seringueiros autonômos roupas, mantimentos, utensílos, exceto nas reservas extrativistas.

Modus Vivendi - fase anterior à assinatura do Tratado de Petrópolis, quando o Acre foi dividido em Acre Meridional e Acre Setrentional.

Plano Stevenson - instrumento de restrição compulsória da produção de borracha , por meio do estabelecimento de quotas de exportação, atribuídas individualmente como um percentual do montante produzido por esta unidade, durante o ano agrícola de 1920. É, portanto, resultante da crescente pressão dos capitais investidos sob o governo britânico, fazendo com que este, em 1922 adotasse o referido Plano. Este Plano se constituiu um forte estímulo a produção da borracha fora dos domínios ingleses, de tal forma que em novembro de 1928 foi desativado devido sua comprovada inoperância.

Processo Arante - assim denominada em função do seu criador chamar-se Francisco Arantes. Este método consistia na coagulação e defumação do látex por meio de um ácido pirolenhoso bruto, também chamado de "seiva amazônica", por ser obtido da fumaça produzida pela queima de madeiras e côcos. O método consistia em misturar a madeira e os côcos na proporção de 2/1, duas partes de madeira para uma de côcos.

RDC - Rubber Development corporation surgiu dos diversos conflitos atinentes a política do Board of Economic Warfare que teimava em aplicar à América Latina a política laissez-faire 
em detrimento dos prob;emas sociais e de desenvolvimento dos países periféricos e a Reconstruction Finance Corporation que defendia uma política mais favorável ao desenvolvimento destes países, ainda que sob o controle de Washington. A esta organização foi atraibuída a total responsabilidade pelo desenvolvimento das fontes de suprimento e pela aquisição de toda a borracha produzida fora dos Estados Unidos visando suprir as demandas do esforço de guerra. Possuía escritórios em Manaus e Belém e a Divisão instalada no Rio de Janeiro, a qual compreendia todos os outros estados brasileiros que estavam empenhados na produção da borracha.

RRC - Rubber Reserve Company, ag6encia americana responsável pela implementação da "batalha da borracha" na Amazônia, a qual foi substituída em 23 de fevereiro de 1943 pela Rubber Development Corporation.

Regatão - embarcação para comércio ambulante nos rios e igarapés. Ë um batelão de regular tamanho impelido a remo de faia. Tem tolda corrida e um camarim com balcão e prateleiras. O comércio abrangia: fazendas, calçados, estivas, miudezas, quinquilharias. A palavra era utilizada para designar o dono.

SAVA - Superintendência para o Abastecimento do Vale Amazônico, criada em 4 de dezembro de 1942, com a finalidade de superintender o abastecimento de gêneros alimentícios e outros de primeira necessidade o Vale Amazônico. Era subordinada a Comissão de Controle dos Acordos de Washington e embora sediada em Belém, sua jurisdição compreendia os estados do Pará, Amazonas, Território do Acre, a zona Sul do estado do Maranhão e o Norte dos estados de Mato Grosso e Goiás. 
SEMTA - Serviço de Encaminhamento de Trabalhadores para a Amazônia criado em 30 de novembro de 1942 tinha como atribuições principais proceder os estudos necessários para transportar, por vias interiores, os trabalhadores nordestinos para a Amazônia, organizar o sistema de recrutamento, proteger e assistir os nordestinos durante a viagem do Nordeste à Amazônia, dar assistência médica e econômica aos seus familiares, articular-se com o DNI de forma harmoniosa no cumprimento de suas funções, organizar pontos de pouso em todo o trajeto da viagem, organizar um sistema de comunicação rápido e eficiente entre as instâncias encarregadas de proceder a mobilização e transporte dos nordestinos viabilizando os imprescindíveis serviços de subsistência, assistência médica e ligação entre os trabalhadores e suas famílias.

Seringal - unidade de produção da borracha, localizava-se, em geral, à margem dos rios do Acre e dedicavam-se quase que exclusivamente a extração do látex e a produção das pelas (bolas de borracha), que eram exportadas para as praças de Manaus e Belém, de onde seguiam para os mercados europeus e norte-americanos.

Seringalista - dono do seringal. Senhor das terras. O termo surgiu na década de 1930. Antes eram utilizados seringueiro-patrão, patrão-seringalista ou simplesmente patrão, sempre ilustrado pelo tratamento de coronel ( sobrevivência das patentes fornecidas pela Guarda Nacional).

Seringueiro- extrator do látex na floresta que recebia do patraão-seringalista os equipamentos de trabalho e os mantimentos básicos para a sobrevivência. Sua função era produzir borracha e a entregar ao patrão para pagamento da dívida, alguns obtinham saldo. 
SNAPP - Serviço de Navegação da Amazônia e da Administração do Porto do Pará, responsável pelo tráfego de mercadorias abastecendo os seringais acreanos.

Varadouro - caminho aberto na floresta visando estabelecer a ligação do barracão com as colocações ou destas entre si. 
ANEXOS 


\begin{abstract}
ANEXO A
TRATADO DE PETRÓPOLIS (VERSÕES EM PORTUGUÊS E ESPANHOL) assinado em 17 de novembro de $1903 . *$
\end{abstract}

\title{
EM PORTUGUÊS
}

A República dos Estados Unidos do Brasil e a República da Bolívia, animadas do desejo de consolidar para sempre a sua antiga amizade, removendo motivos de ulterior desavença, e querendo ao mesmo tempo facilitar o desenvolvimento das suas relações de comércio e boa vizinhança, convieram em celebrar um Tratado de permuta de territórios e outras compensações, de conformidade com a estipulação contida no Art. $5^{\circ}$ do Tratado de Amizade, Limites, Navegação e Comércio de 27 de março de 1867.

E para esse fim, nomearam Plenipotenciários, a saber:

O Presidente da República dos Estados Unidos do Brasil, os Srs. José Maria da Silva Paranhos do Rio Branco, Ministro de Estado das Relações Exteriores, e Joaquim Francisco de Assis Brasil, Enviado Extraordinário e Ministro Plenipotenciário nos Estados Unidos da América; e

O Presidente da República da Bolívia, os Srs. Fernando E. Guachalla, Enviado Extraordinário e Ministro Plenipotenciário em Missão Especial no Brasil e Senador da República, e Cláudio Pinila, Enviado Extraordinário e Ministro Plenipotenciário no Brasil, nomeado Ministro das Relações Exteriores da Bolívia;

* MeSQUiTA JÚNIOR, Geraldo. O Tratado de Petrópolis e o Congresso Nacional. Brasília: Senado Federal, 2003, p.70-79. 
Os quais, depois de haverem trocado os seus plenos poderes, que acharam em boa e devida forma, concordaram nos artigos seguintes:

\section{Artigo I}

A fronteira entre a República dos Estados Unidos do Brasil e a da Bolívia ficará assim estabelecida:

$\S 1^{\circ}$ - Partindo da latitude Sul de $20^{\circ} 08^{\prime} 35^{\prime}$, em frente ao desaguadouro da Baía Negra, no rio Paraguai, subirá por este rio até um ponto na margem direita distante nove quilômetros, em linha reta, do forte de Coimbra, isto é, aproximadamente em $19^{\circ} 58^{\prime}$ '05" de latitude e $14^{\circ} 39^{\prime}$ '14" de longitude Oeste do Observatório do Rio de Janeiro (57 47'40" Oeste de Greenwich), segundo o Mapa da fronteira levantado pela Comissão Mista de Limites, de 1875; e continuará desse ponto, na margem direita do Paraguai, por uma linha geodésica que irá encontrar outro ponto a quatro quilômetros, no rumo verdadeiro de $27^{\circ} 1^{\text {' }}$ 22" Nordeste, do chamado "Marco do fundo da Baía Negra", sendo a distância de quatro quilômetros medida rigorosamente sobre a fronteira atual, de sorte que esse ponto deverá estar, mais ou menos, em $19^{\circ} 45^{\prime} 36^{\prime \prime}, 6$ de latitude e $14^{\circ} 55^{\prime} 46^{\prime \prime}, 7$ de longitude Oeste do Rio de Janeiro (5804'12",7 Oeste de Greenwich). Daí seguirá no mesmo rumo determinado pela Comissão Mista de 1875 até $19^{\circ} 2^{\prime}$ de latitude e, depois, para Leste por este paralelo até o arroio Conceição, que descerá até a sua boca na margem meridional do desaguadouro da lagoa de Cáceres, também chamado rio Tamengos. Subirá pelo desaguadouro até o meridiano que corta a ponta do Tamarindeiro e depois para o Norte, pelo meridiano de Tamarindeiro, até 18'54"de latitude, continuando por este paralelo para Oeste até encontrar a fronteira atual.

$\S 2^{\circ}$ Do ponto de interseção do paralelo de $18^{\circ} 54^{\prime}$ com a linha reta que forma a fronteira atual seguirá, no mesmo rumo que hoje, até $18^{\circ} 14^{\prime}$ de latitude e por este paralelo irá encontrar a Leste o 
desaguadouro da lagoa Mandioré, pelo qual subirá, atravessando a lagoa em linha reta até o ponto, na linha antiga de fronteira, equidistante dos dois marcos atuais, e depois, por essa linha antiga, até o marco da margem setentrional.

$\S 3^{\circ}$ Do marco setentrional na lagoa Mandioré continuará em linha reta, no mesmo rumo que hoje, até a latitude de $17^{\circ} 49^{\prime}$ e por este paralelo até o meridiano do extremo Sudeste da lagoa Gaíba. Seguirá esse meridiano até a lagoa e atravessará esta em linha reta até o ponto equidistante dos dois marcos atuais, na linha antiga de fronteira, e depois por esta linha antiga ou atual até a entrada do canal Pedro Segundo, também chamado recentemente rio Pando.

$\S 4^{\mathrm{a}} \mathrm{Da}$ entrada Sul do canal Pedro Segundo ou rio Pando até a confluência do Beni e Mamore os limites serão os mesmos determinados no Artigo $2^{\circ}$ do Tratado de 27 de março de 1867.

$\S 5^{\mathrm{a}}$ Da confluência do Beni e do Mamore descerá a fronteira pelo rio Madeira até a boca do Abunã, seu afluente da margem esquerda, e subirá pelo Abunã até a latitude de $10^{\circ} 20^{\prime}$. Daí irá pelo paralelo $10^{\circ} 20^{\prime}$, para Leste até o rio Rapirran e subirá por ele até a sua na principal.

$\S 6^{\mathrm{a}}$ Da nascente principal do Rapirran irá, pelo paralelo da nascente, encontrar a Oeste o rio Iquiri e subirá por este até a sua origem, donde seguirá até o igarapé Bahia pêlos mais pronunciados acidentes do terreno ou por uma linha reta, como aos Comissários demarcadores dos países parecer mais conveniente.

$\S 7^{\mathrm{a} \infty}$ Da nascente do igarapé Bahia seguirá, descendo por este, sua confluência na margem direita do rio Acre ou Aquiri e subirá por este até a nascente, se não estiver esta em longitude mais ocidental que a de $69^{\circ}$ Oeste de Greenwich.

a) no caso figurado, isto é, se a nascente do Acre estiver em longitude menos ocidental do que a indicada, seguirá a fronteira peloi diano da nascente até o paralelo de $11^{\circ}$ e depois, para Oeste, pon paralelo até a fronteira com o Peru;

b) se o rio Acre, como parece certo, atravessar a longitude de $69^{\mathrm{a}}$ Oeste de Greenwich e correr ora ao Norte, ora ao Sul do citado paralelo de $11^{\circ}$, acompanhando mais ou menos este, o álveo do rio formará a linha, divisória até a sua nascente, por cujo meridiano continuará até o paralelo de $11^{\circ}$ e daí, 
na direção de Oeste, pelo mesmo paralelo, até a fronteira com o Peru; mas, se a Oeste da citada longitude $69^{\circ}$ o Acre correr sempre ao Sul do paralelo de $11^{\circ}$, seguirá a fronteira, desde esse rio, pela longitude de $69^{\circ}$ até o ponto de interseção com esse paralelo de 11 " e depois por ele até a fronteira com o Peru.

\section{Artigo II}

A transferência de territórios resultante da delimitação descrita no artigo precedente compreende todos os direitos que lhes são inerentes e a responsabilidade derivada da obrigação de manter e respeitar os direitos reais adquiridos por nacionais e estrangeiros segundo os princípios do direito civil.

As reclamações provenientes de atos administrativos e de fatos ocorridos nos territórios permutados, serão examinadas e julgadas por um Tribunal Arbitrai composto de um representante do Brasil outro da Bolívia e de um Ministro estrangeiro acreditado junto ao Governo Brasileiro. Esse terceiro árbitro, Presidente do Tribunal será escolhido pelas duas Altas Partes Contratantes logo depois da; troca das ratificações do presente Tratado. O Tribunal funcionará; durante um ano no Rio de Janeiro e começará os seus trabalhos dentro do prazo de seis meses contados do dia da troca das ratificações, i Terá por missão: 1-. Aceitar ou rejeitar as reclamações; $2^{\circ}$. Fixar a importância da indenização; 3-. Designar qual dos dois governos a deve satisfazer.

O pagamento poderá ser feito em apólices especiais, ao par, que vençam o juro de três por cento e tenham a amortização de três por cento ao ano.

\section{Artigo III}

Por não haver equivalência nas áreas dos territórios permutados entre as duas nações, os Estados Unidos do Brasil pagarão uma indenização de $£ 2.000 .000$ (dois milhões de libras esterlinas), 
que a República da Bolívia aceita com o propósito de a aplicar principalmente na construção de caminhos de ferro ou em outras obras tendentes a melhorar as comunicações e desenvolver o comércio entre os dois países.

O pagamento será feito em duas prestações de um milhão de libras cada uma: a primeira dentro do prazo de três meses, contado da troca das ratificações do presente Tratado, e a segunda em 31 dei de 1905.

\section{Artigo IV}

Uma Comissão Mista, nomeada pêlos dois governos, dentro do prazo de um ano, contado da troca das ratificações, procederá à demarcação da fronteira descrita no Artigo I, começando os seus trabalhos dentro dos seis meses seguinte à nomeação.

Qualquer desacordo entre a Comissão Brasileira, e a Boliviana, que não puder ser resolvido pêlos dois Governos, será submetido à decisão arbitrai de um membro da "Royal Geographical Society", de Londres, escolhido pelo Presidente e membros do Conselho da mesma.

Se os Comsissários demarcadores nomeados por uma das Altas Partes contratantes deixarem de concorrer ao lugar e na data da reunião qu forem convencionados para o começo dos trabalhos, os Comissários da outra procederão por si sós à demarcação, e o resultado das suas operações será obrigatório para ambas.

\section{Artigo V}

As duas Altas Partes Contratantes concluirão dentro do prazo de oito meses um Tratado de Comércio e Navegação baseado no princípio da mais ampla liberdade de trânsito terrestre e navegação fluvial para ambas as nações, direito que elas se reconhecem perpetuamente, respeitados os regulamentos fiscais e de polícia estabelecidos ou que se estabelecerem no território de cada uma. Esses regulamentos deverão ser tão favoráveis quanto seja possível à navegação e ao comércio e guardar 
nos dois países a possível uniformidade. Fica, porém, entendido e declarado que se não compreende nessa navegação a de porto a porto do mesmo país, ou de cabotagem fluvial, que continuará sujeita em cada um dos dois Estado às respectivas leis.

\section{Artigo VI}

De conformidade com a estipulação do artigo precedente, e o despacho em trânsito de artigos de importação e exportação, a Bolívia poderá manter agentes aduaneiros junto às alfândegas brasileiras de Belém do Pará, Manaus e Corumbá e nos demais postos aduane que o Brasil estabeleça sobre o Madeira e o Mamoré ou em outras localidades da fronteira comum. Reciprocamente, o Brasil poderá manter agentes aduaneiros na alfầndega boliviana de Villa Bella ou em qualquer outro posto aduaneiro que a Bolívia estabeleça na fronteira comum.

\section{Artigo VII}

Os Estados Unidos do Brasil obrigam-se a construir em solo brasileiro, por si ou por empresa particular, uma ferrovia desde o porto de Santo António, no rio Madeira, até Guajará-Mirim no Mamoré, com um ramal que, passando por Vila Murtinho ou outro ponto próximo( Estado do Mato Grosso), segue a VilaBella( Bolívia) na conflu6encia do beni com o Marmoré . dessa ferrovia, que o Brasil se esforçará por concluir no prazo de quatro anos, usarão ambos os países com direito às mesmas franquezas e tarifas.

$$
\text { Artigo VIII }
$$

A República dos Estados Unidos do Brasil declara que ventilará diretamente com a do Peru a questão de fronteiras relativa ao território compreendido entre a nascente do Javari e o paralelo de $11^{\circ}$, procurando chegar a uma solução amigável do litígio sem responsabilidade para a Bolívia em caso algum.

\section{Artigo IX}

Os desacordos que possam sobrevir entre os dois Governos quanto à interpretação e execução do presente Tratado, serão submetidos a Arbitramento. 


\section{Artigo X}

Este Tratado, depois de aprovado pelo Poder Legislativo de cada uma das duas Repúblicas, será ratificado pêlos respectivos Governos e as ratificações serão trocadas na cidade do Rio de Janeiro no mais breve prazo possível.

Em fé do que, nós, os Plenipotenciários acima nomeados, assinamos o presente tratado, em dois exemplares, cada um nas línguas portuguesa e castelhana, apondo neles os nossos selos.

Feito na cidade de Petrópolis, aos dezessete dias do mês de novembro de mil novecentos e três.

- Rio Branco

- J. F. de Assis Brasil.

- Fernando E. Guachalla.

- Cláudio Pinilla. 


\section{EN ESPANOL}

La República de los Estados Unidos dei Brasil y Ia República de Bolívia, animadas del deseo de consolidar para siempre su antigua amistad, removiendo motivos de ulteriores desavenencias, y queriendo ai mismo tiempo facilitar el desenvolvimiento de sus relaciones de comercio y buena vecindad, convinieron en celebrar un Tratado de permuta de territórios y otras compensaciones, de conformidad con Ia estipulación contenida en el Artículo $5^{\circ}$ del Tratado de Amistad, Límites, Navegación y Comercio de 27 de Marzo de 1867.

Y con ese fin, han nombrado Plenipotenciarios, a saber:

El Presidente de Ia República de los Estados Unidos del Brasil a los Señores José Maria de Silva Paranhos do Rio Branco, Ministro de Estado de Relaciones Exteriores, y Joaquim Francisco de Assis Brasil, Enviado Extraordinario y Ministro Plenipotenciario en los Estados Unidos de America; y

El Presidente de Ia República de Bolivia, a los Señores Fernando E. Çuachalla, Enviado Extraordinario y Ministro Plenipotenciario en Misión Especial en el Brasil y Senador de Ia República, y Cláudio Pinilla, Enviado Extraordinario y Ministro Plenipontenciario en el Brasil, nombrado Ministro de Relaciones Exteriores de Bolivia;

Los cuales, después de haber canjeado sus plenos poderes, que los hallaron en buena y debida forma, acordaron los artículos siguientes:

\section{Artículo I}

La frontera entre Ia República de los Estados Unidos del Brasil y de la Bolivia quedará así establecida:

$1^{\circ}$. Partiendo de Ia latitud Sur de $20^{\circ} 08^{\prime} .35^{\prime \prime}$, frente al desaguadero de la Bahia Negra, en el río Paraguay, subirá por este río hasta un punto en la margen derecha distante nueve kilómetros en línea recta del fuerte de Coimbra, esto es, aproximadamente en $19^{\circ} 58^{\prime} 05^{\prime \prime}$ de latitud y longitud Oeste 
del Observatorio de Rio de Janeiro (57 .47'..40” Oeste de Greenwich), según el Mapa de la frontera levantado por la Comisión Mixta de Límites, de 1875; y continuará desde ese punto, en la margen derecha del Paraguay, por una línea geodésica a encontrar otro punto a cuatro kilómetros en el rumbo verdadero de $7^{\circ} 01$ '22” Nordeste del llamado "Marco del fondo de Bahia Negra", siendo la distancia de cuatro kilómetros medida rigurosamente sobre la frontera actual, de manera que ese punto deberá estar, mas ó menos, en 1945'36", 6 de latitud y 1455'46", 7 de longitud., Oeste de Rio de Janeiro (5804'12",7 Oeste de Greenwich). De allí seguirá en el mismo rumbo determinado por Ia Comisión Mixta de 1875 hasta $19^{\circ} 2^{\prime}$ de latitud y, después para el Este, por ese paralelo hasta el arroyo Concepción, que bajará hasta su desembocadura en lamargen meridional del desaguadero de la laguna de Cáceres, también llamado rio Tamengos. Subirá por el desaguadero hasta el meridiano que corta Ia punta del Tamarinero, y después para el Norte, por el citado meridiano del Tamarinero, hasta $18^{\circ} 54^{\prime}$ de latitud, continuando por ese paralelo para el Oeste hasta encontrar la frontera actual.

$\S 2^{\mathrm{a}}$ Del punto de intersección dei paralelo $18^{\circ} 54^{\prime}$ con la línea recta que forma Ia frontera actual seguirá, por el mismo rumbo que ai presente, hasta $18^{\circ} 14^{\prime}$ de latitud y por ese paralelo irá a encontrar ai Este el desaguadero de Ia laguna Mandioré, por el cual subirá atravesando la laguna en línea recta, hasta el punto de Ia línea de Ia antigua frontera equidistante de los dos marcos actuales, y después, por esa línea antigua, hasta el marco de la margen setentrional.

$\S 3^{\mathrm{a}}$ Del marco setentrional de Ia laguna Mandioré continuará en línea recta, en el mismo rumbo que ai presente, hasta la latitud de $17^{\circ} 49^{\prime}$, y por este paralelo hasta el meridiano dei estremo Sureste de laguna Gahiba. Seguirá ese meridiano hasta Ia laguna y atravesará esta en línea recta hasta el punto equidistante de los dos marcos actuales, en Ia línea de Ia antigua frontera, y, después, por esta línea antigua o actual, hasta la entrada dei canal Pedro Segundo, llamado recientemente rio Pando.

$\S 4^{\mathrm{a}}$ De Ia entrada Sur del Canal Pedro Segundo o rio Pando hasta la confluência del Beni y del Mamoré, los limites serán los mismos determinados en el Artículo 2- del Tratado de 27 de Marzo de 1867. 
$\S 5^{\text {a }}$ Desde Ia confluência del Beni y del Mamoré bajará la frontera por el rio Madera hasta la boca del Abuná, su afluente de la margen izquierda, y subirá por el Abuná, hasta la latitud de 10²0'. De allí irá por el paralelo $10^{\circ} 20^{\prime}$ para el Oeste, hasta el rio Rapirran y subirá por este hasta su naciente principal.

$\S 6^{\mathrm{a}}$ De la naciente principal del Rapirran, irá por el paralelo de la naciente a encontrar al Oeste el rio Iquiry y subirá por este hasta su origen, desde donde seguirá hasta el arroyo de Bahia por los más pronunciados accidentes del terreno o por una línea recta, como pareciere más conveniente a los Comisarios demarcadores de ambos países.

$\S 7^{\mathrm{a}}$ De la naciente del arroyo de Bahia seguirá, bajando por este, hasta su desembocadura en la margem derecha del rio Acre o Aquiry y subirá por este, hasta la naciente, si no estuviese esta en longitud más ocddental que la de $69^{\circ}$ Oeste de Greenwich:

a) En el caso figurado, esto es, si la haciente del Acre estuviere en longitud menos occidental que la modificada, seguira la frontera por el meridiano de la naciente hasta el paralelo $11^{\circ}$ y despues, para el Oeste, poe esse paralelo hasta la fontera com el Peru;

b) si el río Acre, como parece evidente, atravesare la longitud de $69^{\circ}$ Oeste Greenwich y corriere ya al Norte, ya al Sur del citado paralelo $11^{\circ}$, acompanando más ó menos este, el alveo del rio formará la línea divisória hasta su naciente, por cuyo meridiano continuará hasta el paralelo $11^{\circ}$ y de allí, en dirección al Oeste, por el mismo paralelo, hasta la frontera con el Peru; más, si ai Oeste de la citada longitud $69^{\circ}$ el Acre corriere siempre ai Sur del paralelo $11^{\circ}$, seguirá Ia frontera, desde ese rio, por Ia longitud $69^{\circ}$ hasta el punto de intersec-ción con ese paralelo $11^{\circ} \mathrm{y}$ después por el, hasta Ia frontera con el Peru.

\section{Artículo II}

La transferencia de territórios resultante de la limitación descrita ; en el artículo anterior comprende todos los derechos que lês son inherentes y Ia responsabilidad derivada de Ia obligación de mantener y tapetar los derechos reales adquiridos por nacionales y extranjeros según los princípios del derecho civil. 
Lãs reclamaciones provenientes de actos administrativos y de hechos ocurridos en los territórios permutados, serán examinadas y juzgadas por un Tribunal Arbitrai compuesto de un representante del, otro de Bolívia y de un Ministro extranjero acreditado ante el tio Brasileno. Este tercer árbitro presidente deil Tribunal, será por las dos Altas Partes Contratantes después del canje de las ratificaciones del presente Tratado. El Tribunal funcionará durante un año en Rio de Janeiro y dará principio a sus trabajos en el plazo de seis contados desde el dia del canje de las ratificaciones. Tendrá por : 1-Aceptar o rechazar las reclamaciones; 2-- Fijar el monto de la indemnización; 3- - Designar cual de los dos Gobiernos la debe satisfacer.

El pago podrá ser hecho en bonos especiales a la par, que ganen el interes por ciento y tengan la amortización del três por ciento anual.

\section{Artículo III}

Por no haber equivalência en las áreas de los territórios permutados entre las dos naciones, los Estados Unidos del Brasil pagarán una indemnización de £ 2.0000.00 (dos millones de libras esterlinas), que la República de Bolívia acepta con el propósito de aplicarla principalmente a la construcción de caminos de hierro ú otras obras tendientes a mejorar las comunicaciones y desenvolver el comercio entre los dos países.

Os Estados Unidos do Brasil obrigam-se a construir em brasileiro, por si ou por empresa particular, uma ferrovia desde o porto de Santo António, no rio Madeira, até Guajará-Mirim no Mamoré, com um El pago será hecho en dos partidas de un millón de libras cada uma: la primera denro del plazo de três meses, contado desde el canje de las retificacions del presente Tratado, y Ia segunda el 31 de Marzo de 1905 . 


\section{Artículo IV}

Una Comisión Mixta, nombrada por los dos Gobiernos dentro del plazo de un ano, contado desde el canje de las ratificaciones, procederá ala demarcación de la frontera descrita en el artículo I, principiando sus trabajos a los seis meses siguientes a su nombramiento.

Cualquier desacuerdo entre la Comisión Brasilena y la Boliviana que no pudiere ser resuelto por los dos Gobiernos, será sometido a la decisión arbitrai de un miembro de la "Royal Geographical Society", de Londres, escojido por el Presidente y miembros del Consejo de la misma

Si los Comisarios demarcadores nombrados por una de las Altas Partes Contractantes dejasen de concurrir al lugar y fecha que fueren convenidos para dar principio a los trabajos, los Comisarios de la otra procederán por si solos a la demarcación, y el resultado de sus operaciones será obligatorio para ambas.

\section{Artículo V}

Lãs dos Altas Partes Contractantes concluirán dentro del plazo de ocho meses un tratado de Comercio y Navegación, basado en el principio de la más amplia libertad de trânsito terrestre y navegación fluvial para ambas naciones, derecho que ellas se reconocen a perpetuidad, respetando los reglamentos fiscales y de policia estabelecidos o que se establecieren en el território de cada una. Eses reglamentos deberán ser tan favorables cuanto sea posible a la navegación y ai comercio y guardar en los dos países la posible uniformidad. Queda, sin embargo, entendido y declarado que no se comprende en esa navegación la de puerto a puerto del mismo país, o de cabotage fluvial, que continuará sujeta en cada uno de los dos Estados a sus respectivas leyes. 
En conformidad a la estipulación del Artículo precedente, y para el despacho en trânsito de artículos de importación, y exportación, Bo-livia podrá mantener agentes aduaneros junto a las aduanas brasilenas de Belém del Pará, Manaus, Corumbá y demas puertos aduaneros que el Brasil establezca sobre el Madera, Mamoré o otras localidades de la frontera común. Reciprocamente, el Brasil podrá mantener agentes aduaneros en la aduana de Villa Bella o en qualquier outro puesto aduanero que Bolivia estabiezca en la frontera comum.

\section{Artículo VII}

Los Estados Unidos dei Brasil se obligan a construir en território kasileno, por si o por empresa particular, un ferrocarril desde el puerto de Santo António, en el rio Madera, hasta Guajará-mirim, en el Mamoré, con un ramal que, pasando por Villa-Murtinho o otro punto próximo (Estado de Mato Grosso), Üegue a Villa Bella (Bolívia), en Ia confluência dei Beni con el Mamoré. De ese ferrocarril, que el Brasil se tstorzará en concluir en el plazo de cuatro anos, usarán ambos países conderecho a las mismas franquicias y tarifas.

\section{Artículo VIII}

La República de los Estados Unidos del Brasil declara que ventilará directamente con la del Peru la cuestion de fronteras relativa al território comprendido entre la naciente del Yavary y el paralelo $11^{\circ}$, procurando llegar a una solución amigable del litígio sin responsabili-dad para Bolívia en ningún caso. 
Los desacuerdos que puedan sobrevenir entre los dos Gobiernos encuanto a la interpretación y ejecución del presente Tratado, serán sortidos a Arbitraje.

\section{Artículo X}

Este Tratado después de aprobado por el Poder Legislativo de cada una de las dos Repúblicas, será ratificado por los respectivos Gobiernos y las ratificaciones serán canjeadas en la ciudad de Rio de Janeiro, en el más breve plazo posible.

En fé de lo cual, nosotros, Plenipotenciários arriba nombrados, firmamos el presente Tratado, en dos ejemplares, cada uno de ellos en las lenguas portuguesa y castellana, y lês ponemos nuestros respectivos sellos.

Hecho en la ciudad de Petrópolis, a los diecisiete dias del mês de noviembre de mil novecientos três.

- Rio Branco

-J. F. de Assis Brasil

-Fernando E. Guachalla

- Cláudio Pinilla 


\section{ANEXO B}

TRATADO VELARDE RIO BRANCO (08 de setiembre de 1909)

Durante mucho tiempo siguió el Perú con el Brasil la fácil y, a la larga, perjudicial política de los aplazamientos, contenta su cancillería con no asumir las responsabilidades de un arreglo, alucinados algunos escritores con las líneas trazadas ilusamente en los mapas sobre la base de títulos que el Brasil no reconocía.

Entre tanto la penetración brasileña en la amazonía avanzaba. Si el tratado hubiese sido firmado antes, la solución había sido más beneficiosa. Si hubiera sido años después, los daños seguramente habrían sido peores.

El Brasil, vecino de casi todas las Repúblicas sudamericanas, trató con cada una de ellas por separado, a lo largo del siglo XIX y en los primeiros años del siglo XX, y a veces buscó enfrentarlas una a outra. Nunca surgió una tentativa para erigir un frente común hispanoamericano frente a la poderosa nación portuguesa.

JOSÉ MARIA DA SILVA PARANHOS DE RIO BRANCO, diplomático extraordinario, obtuvo por medios pacífricos para su Patria el reconocimiento de grandes cantidades de kilómetros como si hubiera triunfado en cruentas guerras.

En el Perú las líneas teóricas del viejo tratado español portugués de San Ildefonso habían creado la ilusión de vastos limites orientales. La mayor fuerza expansiva nacional y el dominio sobre la parte baja de los ríos amazónicos favorecieron la posesión brasilera. Ya en 1841, 1851 y 1858 el Perú hubo de reconocer un uti possidetis de facto. 
Sobre el destino de este problema influyó una serie de sucesos que se eslabonaram a través de muchos años. Entre ellos estuvieron: el reconocimiento que el Brasil hizo de las pretensiones de Bolivia en 1867 mediante el tratado Muñoz-Netto; el hallazgo del origen del río Yavarí por la comisión de 1874 en una situación geográfica que los negociadores de 1851 no habían sospechado; la rectificación del cálculo de este origen hecho por el brasilero Cunnha Gómez en 1897 para dejar al Brasil 1200 Km2 más de territorioi; la negativa del govierno del Perú para enviar una expedición al Acre en 1901; el tratado de Petrópolis firmado em 1903 entre Bolivia y el Brasil y el modus vivendi peruano brasileño de 1904 que neutralizó la hoya del Alto Yurá y del Alto Purús.

RIO DE JANEIRO 08 DE SETIEMBRE DE 1909 - (VELARDE - RIO BRANCO) Mediante el tratado suscrito en Río de Janeiro el 08 de Setiembre de 1909, por el canciller del Brasil José Maria da Silva Paranhos de Río Branco y el pleni-potenciario peruano Hernán Velarde, se completó la demarcación entre los dos países que iniciara la convención fluvial sobre comercio y navegación de 1851 en la dirección fluvial sobre comercio y del Yavarí hasta el rio Caquetá o Yapurá. Las partes contratantes acordaron que de la referida naciente del Yavarí hacia el Sur y hacia el Este, los confines de los países qudarán así establecidos.

1. - "De la naciente del Yavarí seguirá la frontera en la dirección del Sur, por la línea divisoria de las aguas que van para el Ucayali de las que corren por Yuruá hasta encontrar el paralelo $9^{\circ} 24^{\prime} 36^{\prime \prime}$ que es el de la boca del Breu, afluente de la orilla derecha del Yuruá".

2. - "Continuará en la dirección del Este por el indicado paralelo hasta la confluencia del Breu y subirá por el álveo de este río hasta su cabecera principal".

3. - "De la cabecera principal del Breu proseguirá rumbo al Sur, por la línea que divide las aguas que van para el alto Yuruá, al Oeste, de las que van por el mismo río al Norte y, 
pasando entre las cabeceras del Tarahuacá y del Envira, del lado del Brasil y las del Piqueyaco y Toroyuc del lado del Perú, irá por el divortium aquarum entre el Envira y el afluente de la margen izquierda del Purús llamado Curanja o Curumahá, cuya cuenca pertenecerá al Perú hasta encontrar la naciente del río de Santa Rosa o Surinahuá, afluente también de la orilla izquierda del Purús. Si las cabeceras del Tarahuacá y del Envira estuviesen al Sur del paralelo $10^{\circ}$ latitud sur, la línea continuará por el divortium aquarum entre el Envira y el Curanja o Curumahá hasta encontrar la naciente del río Santa Rosa”.

4. - "De la naciente del río Santa Rosa bajará por el álveo de esse río hasta su confluencia en la orilla izquierda del Purús".

5. - “Frente a la boca del río Santa Rosa, la frontera cortará al río Purús hasta el medio del canal más hondo y de allí continuará en la dirección del Sur, subiendo por el Purús hasta llegar a la confluencia del Shambuyaco, sua afluente de la margen derecha entre Catai y el Santa Rosa".

6. - "De la boca del Shambuyaco subirá por el álveo de esa corriente de agua hacia su naciente".

7. - "De la naciente del Shambuyaco continuará hacia el Sur, ceñida al meridiano de esa naciente hasta encontrar la margen izquierda del río Acre o Aquiry o, si la naciente de este río estuviera más al oriente, hasta encontrar el paralelo $11^{\circ}$ ”.

8. - "Si el citado meridiano de la naciente del Shambuyaco atravesara el río Acre, continuará la frontera, desde el punto de encuentro por el álveo del mismo río Acre, bajando por él, hasta el punto en que empiece la frontera Perú-boliviana en la orilla derecha del Alto Acre".

9. - "Si el meridiano de la naciente del Shambuyaco no atravesara el río, es decir si la naciente del Acre estuviese al Oriente de ese meridiano, la frontera desde el punto e 
intersección de aquel meridiano con el paralelo $11^{\circ}$ proseguirá por los más pronunciados accidentes del terreno o por una línea recta, como pareciese más conveniente a los comisarios demarcadores de los dos países hasta encontra la naciente del río Acre y después bajando por el álveo del mismo río Acre, hasta el punto en que empiece la frontera Perú-Boliviana en la orilla derecha del Alto Acre".

El tratado estabeleció una comisión mixta para la demarcación de las líneas fronterizas y dió algunas normas para su funcionamiento. Fijó además normas para impedir el contrabando.

Ratificó por otra parte el principio de la más amplia libertad de tránsito terrestre y navegación fluvial para ambas naciones en todo el curso de los ríos que nacen o corren dentro o en las extremidades de la región atravesada por dichas líneas.

Fué aprobado por el Congreso Peruano el 10 de Enero de 1910 por 95 votos contra 15. Emitieron dictámenes favorables los miembros de la Comisión Diplomática Javier Prado y Ugarteche, Amador del Solar y Francisco Tudela y Varela (conjuntamente) por separado Antonio Miro Quesada e Hildebrando Fuentes y en forma individual Víctor Eguiguren. El dictamen en contra fué de Joaquin Capelo y Aurelio Sosa.

Era presidente del Perú Don Augusto B. Leguía y del Brasil Nilo Pecanha.

Al defender el tratado Velarde Río Branco en una polémica con el ex-presidente José Pardo y Barreda, Melitón Porras, el Canciller bajo cuya responsabilidad fué firmado dicho arreglo, expresó en unas Cartas publicadas en el "Comercio" del 22 de Octubre de 1919 y el 12 de Enero de 19201 o siguiente:

1. - Ya el Perú en 1851 (presidencia de Echenique) había reconocido el uti possidetis de facto com el Brasil. 
2. - El modus vivendi peruano-brasilero de 1904 prorrogado hasta 1908 refrendó en principio de la posesión; después de él, todo el territorio al oriente de las zonas neutralizadas estaba perdido para el Perú si se celebraba un arreglo definitivo.

3. - El Tratado Velarde-Río Branco, que fué superior al modus vivendi de 1904, obtuvo $1^{\text {a }}$ zona neutralizada íntegra para el Perú, si bien acató la soberanía del Brasil al Este de ella.

4. - Con este tratado quedó detenida la expansión del Brasil que hubiera podido llegar con el tiempo a las márgenes del Ucayali. Esta razón puede considerarse com fundamental.

5. - El Perú tenía la condición, de país débil y el Brasijl las características de país fuerte. Como el Perú se enfrentaba entonces a una grave situación internacional por el peligro de que fuese víctima de una agresión simultánea efectuada por sus vecinos azuzados por Chile, es decir de lo que entonces se llamó un "cuadrillazo", la amistad con el Brasil era útil y conveniente dentro del juego de la política sudamericana como lo demonstró su mediación de 1910 con Argentyna y Estados Unidos en el Conflicto con el Ecuador. Aparte de ello, dicha amistad sirvió para suministrar facilidades en la navegación de los ríos, en las actividades comerciales y en las relaciones de vecindad.

No mencionó Porras el peligro de una alianza brasilero-ecuatoriana. Jorge Pérez Concha en su ensayo histórico-Crítico de las relaciones diplomáticas del Ecuador con los Estados limítrofes (Quito 1958) alude al tratado secreto suscrito entre las cancillerías del Río de Janeiro y de Quito en mayo de 1904 cuyos artículos principales expresaban lo siguiente:

1. - "Brasil y Ecuador se unen en alianza defensiva para evitar toda agresión de parte del Perú y para oponerse a que el gobierno de aquel país ocupe militar o administrativamente territorios a que aquellos países creen tener derecho y que fuero poseídos por el Perú a la fecha de su separación de España”. 
2. - "Para obtener el objeto que se propone esta alianza los dos países contratantes concurrirán con todos los elementos bélicos de que puedan disponer y ejercitarán su acción militar como sea preciso, por el lado del pacífico o por el lado del amazonas”. Según el mismo Pérez Concha el plenipotenciario ecuatoriano llegó entonces al extremo de pedir al Canciller Río Branco que “aceptase la cesión de una zona del territorio disputado con el Perú desde Tumbes hasta el Brasil a fin de que este país llegase a ser potencia del pacífico". En caso del aplazamiento o del rechazo del tratado en Lima, el Brasil estuvo dispuesto a ponerse de acuerdo con el Ecuador y con colombia para una política adversa al Perú.

Brasil pues em 1909, prefirió al entendimiento bélico con el Ecuador el menos complejo arreglo pacífico con el Perú.

Como resultado de este convenio, Melitón Porras negó que la bandera peruana o que ciudadanos peruanos reclamarán en nombre de propriedades situadas en los territorios cedidos o que Brasil crease nuevas circunscripciones administrativas en esas zonas. Sobre, ellas, dijo, el Perú sólo decía tener títulos y únicamente podía presentar alegatos refutados, a sua vez, por otros títulos y otros alegatos.

Hernán Velarde reveló en una carta publicada en "El Comercio" del 27 de Enero de 1920 un cambio de comunicaciones que tuvo con el ex-Presidente José Pardo y Barreda a propósito del tratado com el Brasil. El 10 de Frebrero de 1910 le manifestó éste su opinión adversa a dicho pacto, en una misiva dirigida de París a Río de Janeiro. La respuesta se produjo el 04 de Octubre del mismo año. El gobernante de 1904-1908, o sea José Pardo y Barreda era hóstil al arreglo "porque cedemos al Brasil todas nuestras expectativas sin ninguna compensación, porque esa cesión constituye un sacrificio estéril, desde que la llava de nuestros dificultades externas no está en Río sinó en Santiago; porque habiendo cedido al 
Brasil, nos hemos debilitado ante Chile que nos ha visto ceder; porque el Brasil, que nada tiene ya que esperar de nosotros, se inclinará del lado de sus conveniencias; y finalmente, porque la intervención brasileña en la Aduana de Iquitos es perjudicial a nuestras finanzas".

Así resumió Velarde los argumentos de su ilustre Crítico. Y así los replicó: “Cuáles son las expectativas que sacrifica el tratado? Acaso la de llegar a transformarnos, corriendo los siglos, en un pueblo fuerte, inescrupuloso y guerrero, apto por consiguiente para imponer al Brasil las líneas del tratado de San Ildefonso com la punta de las bayonetas? o, tal vez, por acto de locura o de capricho, el Brasil nos abandonase algún dia sus posesiones para que las ocupásemos holgadamente hasta levantar marcos fronterizos entre los orígenes del Yavarí o el medio Curso del Madera o más allá?”. Mis alcances no llegan a descubrir otras expectativas abrigando, en contrario, la convicción de que la única promesa cuya realización nos resrvaba el porvenir era la completa posesión del Brasil sobre la Cuenca de los ríos que bañan el Oriente y con ella, el aniquilamiento del único título que, como consecuencia de los errores cometidos por nuestros gobernantes, podíamos licitamente invocar en la frijación de nuestros fronteras con esta República, título que no era outro que el de la posesión efectiva en el momento de las negociaciones. Dueño el Brasil de la boca de esos ríos, enorme riqueza fiscal, numerosa población y poderoso comercio, su natural ensanche de posesión sobre territorios productivos, no debilitados, sin dueño aparente y en completo abandono era el cumplimiento de una ley fatal. Descartar semejante expectativa no es, pues un daño; muy por el contrario, es conjurar un peligro de los mayores; y es eso lo que se ha hecho al celebrar el tratado".

"Dicen que Chile nos ha visto ceder y que, por esa circunstancia, hemos perdido fuerzas en el litigio que sostenemos con esse país; afirmación sin fundamento, porque nadie puede ver lo que no existe".

Lo que chile ha visto, lo que está palpando, es la inutilidad de sus esfuerzos para impedir que alcancen solución nuestras dificultades externas; lo que Chile contempla con 
mirada atónica, es precisamente este tratado con el Brasil, negociado y firmado sin que el ministro chileno en Río se apercibiese de ello y adverso, en tal forma a los planes y conveniencias de aquella República, que dió lugar a la reclamación que aquel Ministro presentara al Canciller brasileño por haber faltado el Brasil, en concepto de Chile, al espíritu de las relaciones chileno-brasileñas, al negociar y suscribir semejante tratado con el Perú, enemigo de Chile, sin darle conocimiento ni contar con su anuencia; reclamación que, como es fácil suponer, rechazó Rio Branco en términos enérgicos y perentetorios.

En cuanto a la intervención brasileña, en la Aduana de Iquitos, Velarde aseveró que su único objeto era impedir el contrabando y que el tratado también establecía la permanencia de interventores peruanos en las aduanos brasileñas de la frontera, sin excluir las de Manaos y el Perú.

"De parte del Perú, la eliminación de una expectativa desastrosa; de parte del Brasil, la liquidación legal y pacífica de la última de sus cuestiones fronterizas y, para ambos pueblos la consolidación de una amistad perpétua, sin recelos ni sombras”. Así sintetizaba Velarde en su réplica a Pardo el significado del pacto suscrito por él en Río de Janeiro el 08 de Setiembre de 1909.

En un artículo publicado en el "Comercio" el 27 de Frebrero de 1920, Carlos Wiesse, también se manifestó favorable a dicho arreglo. Dijo que “el examen de los pactos ajustados entre Portugal y España antes de la Independencia sobre cartas geográficas de la época, el de las estipulaciones de la Presidencia de Echenique de 1851, la pérdida de nuestra aproximación al Madeira por el laudo argentino en Julio de 1909 y otros hechos de esa misma época, habían convencido a muchísimos patriotas peruanos que en un arbitraje de juris o de facto, el Brasil sacaría a su favor un línea de fronteras que se confundiria probablemente con la del divortium aquarum, entre las hoyas del Ucayali y las del Yuruá y el Purús”. "El tratado Velarde-Rio 
Branco alejó definitivamente al Brasil de esa línea, adjudicó al Perú todo el terreno neutralizado por instruciones del Ministro Elmore y otros retazos de relativa importancia”.

Rio Branco y Velarde suscribieron en Petrópolis el 07 de Diciembre de 1909 outro tratado; fué el arbitraje sobre controversias que no afectaram intereses vitales, integridad territorial, soberanía un honor nacional. En caso de ponerse en ejucución el compromiso arbitral, cada país debia proponer un árbitro, sujeto a la aceptación del outro; y a ambos personeros correspondia elegir un tercero para presidirlos. 


\title{
ANEXO C \\ PROJETO No 2.654-C/57 - NA CÂMARA DOS DEPUTADOS. * PROJETO N 45/61 - NO SENADO FEDERAL
}

\author{
Eleva o Território do Acre à categoria de Estado e dá outras \\ providências.
}

O Congresso Nacional decreta:

Art. $1^{\circ}$. O Território do Acre, com seus atuais limites, é erigido em Estado do Acre.

Art. $2^{\circ}$. A Justiça Eleitoral fixará, dentro de três meses, após a promulgação da presente lei, a data das eleições de Governador e de Deputados à Assembléia Legislativa, os quais serão em número de quinze e terão, inicialmente, funções constituintes.

Art. $3^{\circ}$. A Assembléia Legislativa reunir-se-á dentro de dez dias da diplomação, sob a direção do Presidente do Tribunal Regional Eleitoral, por convocação deste, e elegerá a sua Mesa.

Parágrafo único. Se, dentro de quatro meses, após a instalação da Assembléia, não for promulgada a Constituição Estadual, o Estado do Acre ficará submetido automaticamente à do Estado do Amazonas, até que a reforme pelo processo nela determinado.

Art. $4^{\circ}$. A posse do primeiro Governador se dará perante a Assembléia Legislativa, no dia da promulgação da Constituição Estadual.

Parágrafo único. Até essa data, o Estado do Acre ficará sob a administração do Governo Federal, através de um governador provisório.

Art. $5^{\circ}$. O mandato dos deputados eleitos, na forma do art. $2^{\circ}$, findará a 31 de janeiro de 1962.

Art. $6^{\circ}$. O número de representantes do Estado do Acre na Câmara dos Deputados será fixado em lei especial, e a sua eleição, juntamente com a dos Senadores, verificar-se-á na data das eleições gerais do Congresso Nacional para a próxima Legislatura.

Parágrafo único. O Senador eleitor com a menor votação, terá o mandato de quatro anos.

Art. $7^{\mathbf{0}}$. As dotações consignadas no atual Orçamento Geral da União, para o Território do Acre, serão transferidas à aplicação do Governo do Estado, mediante convênio.

Parágrafo único. No exercício financeiro subseqüente ao da promulgação da Constituição Estadual, o Governo do Acre perceberá da União um auxílio correspondente ao valor global das verbas orçamentárias que hajam sido atribuídas ao Território, no exercício anterior.

* KALUME, Jorge. Elevação do Território do Acre a estado. Brasília: Senado Federal, 1985, p. 480-482 
Art. $8^{\circ}$. A União celebrará convênio com o Estado do Acre, a vigorar a do exercício financeiro seguinte, ao da promulgação da Constituição do Estado, para que:

a) a União concorra, durante o período de dez anos contínuos, com um auxílio anual não inferior a Cr\$ 300.000.000,00 (trezentos milhões de cruzeiros), e mais, por tempo indeterminado com a contribuição de que trata o art. $9^{\circ}, \S 6^{\circ}$.

b) O Estado se obrigue, no mesmo prazo a:

1 - aplicar, no mínimo, 50\% (cinqüenta por cento) desse auxílio no fomento da riqueza regional;

2 - limitar ao máximo de $3 \%$ (três por cento), por transação, a incidência do imposto de vendas e consignações.

Art. $9^{\circ}$. A partir da data da promulgação da Constituição Estadual, ficam atribuídos ao Estado do Acre e a ele incorporados:

a) todos os bens, serviços e respectivo pessoal ativo e inativo do Território do Acre;

b) todos os serviços públicos de natureza local, exercidos pela União no Território do Acre e por ela não aproveitados, inclusive a Justiça, o Ministério Público, a Polícia e a Guarda Territorial com todos os respectivos bens e pessoal ativo.

$\S 1^{\circ}$. O pessoal dos serviços mantidos pela União e transferidos ao Estado na forma deste artigo, continuará a ser remunerado pela União, inclusive o que passar à inatividade; mas passarão a ser remunerados pelo novo Estado, que os proverá na forma da lei, os novos servidores nomeados para cargos iniciais de carreira ou cargos isolados que se vagarem e para cargos que vierem a ser criados, bem como os acréscimos de vencimentos, proventos e vantagens estabelecidos pelo novo Estado.

$\S 2^{\circ}$. A aposentadoria dos servidores remunerados pela União será por essa decretada, ficando a seu cargo o pagamento dos respectivos proventos, e também assegurado sem restrições, o direito dos atuais contribuintes de entidades federais de previdência.

$\S 3^{\circ}$. Todos os bens móveis e imóveis, encargos e rendimentos, inclusive os de natureza fiscal, direitos e obrigações relativos aos serviços mantidos pela União no Território, passarão ao patrimônio do novo Estado, sem indenização, na data da promulgação de sua Constituição.

$\S 4^{\circ}$. Os serviços transferidos na forma deste artigo continuarão regidos pela legislação vigente, enquanto não modificada pelos Poderes competentes do novo Estado, ao qual incumbe sobre eles legislar, inclusive sobre o pessoal transferido, bem como administrálos, provendo-lhes e movimentando-lhes os quadros.

$\S 5^{\circ}$. Os servidores federais, transferidos ao novo Estado, serão remunerados pela União de maneira nunca inferior aos de mesmo cargo ou de correspondente categoria nos demais Territórios Federais.

$\S 6^{\circ}$. Caberá à União auxiliar o Estado a pagar aos desembargadores do Tribunal de Justiça a diferença entre os seus vencimentos e os dos juízes de entrância mais elevada ou única, até ser a mesma absorvida por majorações outorgadas pelos Poderes constitucionais do Estado. 
Art. 10. Caberá à União o pagamento da importância que for em definitivo arbitrada como justa indenização ao Estado do Amazonas, pela perda do Acre Setentrional.

Art. 11. Até que seja instalado o Tribunal Regional Eleitoral do Acre, suas funções serão exercidas pelo Tribunal Regional Eleitoral do Distrito Federal.

Art. 12. As verbas e créditos orçamentários ou especiais destinadas ao Estado do Acre, em virtude da presente lei, independem de registro prévio no Tribunal de Contas e serão depositados com caráter prioritário, em conta especial do Banco do Brasil S. A, à disposição do Governo estadual, em três parcelas iguais, durante os meses de março, julho e novembro de cada ano.

Art. 13. Esta lei entrará em vigor na data de sua publicação, revogadas as disposições em contrário ${ }^{1}$. 


\section{ANEXO D \\ DISCURSO DO GOVERNADOR JOSÉ AUGUSTO DE ARAÚJO*}

Assumo no dia de hoje o Poder Executivo de minha terra, lançando o meu pensamento e o meu coração para os anos idos e vividos como se, criança, pudesse antever as etapas evolutivas por que o Acre teria que passar e está passando, no encalço do seu verdadeiro destino.

Na verdade instala-se hoje, no Acre, um Governo novo. Na forma e no fundo esta terra, como que num salto brusco, galga mais um degrau na histórica peregrinação dos seus passos, rumo ao progresso. E temos que reconhecer que essa marcha insólita não se delineia através de estrada larga antes, através de caminhos tortuosos e íngremes, esperando que autênticos pioneiros dispensem, se necessário, todas as parcelas de suas atividades em prol de sua evolução, para que os acreanos sejam dignos de sua própria História e apaguem a mancha com que prepostos oportunistas enodoaram as suas páginas, sangrentas, mas aí não mais em conseqüência de duros e heróicos combates, sim, pelo assassinato covarde de Plácido de Castro, o maior pioneiro que por aqui passou.

Não podemos dinamizar o presente, modificá-lo, preparando o futuro, sem conhecer o passado. Inspiramo-nos no exemplo dos nossos maiores, aparecidos com os acontecimentos históricos e, pela análise séria, real, de diversos fatores, cumpre-nos o dever de retomar o fio da meada no momento histórico certo, sem desviá-lo para caminhos que a covardia, o oportunismo e a corrupção inspiram a tantos. Inspiração negativa, que faz a muitos ver em chocantes picadas infectas, plenas das miasmas deletéricas geradas pelo atraso, a ignorância, e conservadas prazeirosamente pelos corrompidos e corruptores - a miragem deslumbrante da 
estrada larga que conduz ao nirvana. Sabemos que esse processo evolutivo nem sempre ocorre de forma contínua, mesmo porque é enorme a influência que os homens exercem, na transmutação de causa e efeito, sobre a marcha da própria História. Por isso, felizes daqueles que, pelo estudo, pelo espírito de pesquisa e sentimento de honestidade, colocam-se à altura de empreender aquela retomada no sentido da verdadeira evolução, contribuindo, historicamente, para destruir as influências da miragem dos diversos caminhos incorretos e que, em prazo de tempo mais ou menos curto, estarão relegados ao esquecimento do povo.

Conterrâneos: a incorporação deste pedaço de terra ao Brasil, como sabemos, não foi ditada por entendimentos de corredores, nem através de fala convincente pormanada de gênios de Embaixada. A influência do grandioso Barão do Rio Branco pode ser citada como uma das últimas entre as principais determinantes. Não pretendo, e nem aqui é o lugar próprio para isto, entrar em minúcias históricas e muito menos fazer sociologia. Mas devemos, em nome da verdade histórica, proclamar sempre a figura que dinamizou a realidade de antanho, perscrutando os sentimentos do povo, as contradições que aqui ocorriam com o seu corolário de injustiças que deviam repercutir no cenário nacional e internacional, dar-lhes sentido; modificar, em meio a obstáculos quase intransponíveis, os anseios de um povo escravizado, mas ignorante, em anseios autênticos de libertação e defesa de um patrimônio que era seu; a figura, repetimos, que dinamizou tudo isso e legou ao nosso povo o maior exemplo de bravura, dignidade e elegância, dentro daquelas características de pioneirismo, foi o grande guerrilheiro gaúcho - Cel. José Plácido de Castro

Plácido de Castro surgiu no momento preciso, quando as condições do meio exigiam a ação que pusesse a termo as irrisórias tertúlias em torno de Tratados; Direito Internacional e exploração imperialista.

* Discurso proferido na ocasião de sua posse na Assembléia Legislativa do Estado do Acre, em 1 de março de 1963. Texto impresso. 
Eis aí, meus caros conterrâneos, quão significativo é o nosso passado e quão glorioso e edificante o exemplo deixado pelo imortal caudilho, homem de ação cujo rosto se fazia banhado de lágrimas por ocasião da imperiosa necessidade do fuzilamento do jovem e irrequieto "Doutor", mas que sabia responder sobranceiramente quando circunstâncias severas o exigiam.

Nossa História está bem viva para que dela não arredemos o passo, tateando caminhos escuros. Saberemos retomar o fio da meada, para uma luta de características diversas da de Plácido, como fenômeno realidade; esforçar-nos-emos para que o idealismo, a ação, e o respeito para com o povo constituam-se em apanágio nosso, dentro da nova realidade, como o foram para o grande herói.

Comprometi-me com o povo e não decepcionarei aqueles que em mim confiaram. Sei que assumo um posto de sacrifício. Tal perspectiva é para mim motivo de incentivo, particularmente quando me lembro que o sacrifício do povo acreano, sempre relegado à própria sorte, tem sido muito maior do que a tudo que se lhe compare. Procurarei fazer justiça a todos, sem discriminações mesquinhas de qualquer natureza, conduzindo, dentro dos postulados trabalhistas, a família acreana pela senda da pacificação para o trabalho e o progresso. Jamais permitirei que aves de rapina encontrem pousada em nosso meio e guerrearei, sem trégua, os indignos corruptores do povo, de nossa mocidade ansiosa de progresso e saber, conjuntamente a nossa infância minada pelo pauperismo, a tuberculose e o impaludismo.

Contarei, disto estou certo, com a colaboração de acreanos cultos e idealistas, plenos de amor à gleba, para o grande trabalho recuperativo do mais novo Estado da Federação. Haveremos de mostrar, na prática, que os acreanos são capazes de grandes coisas, criando condições onde não possa ser possível vicejar a malversação e o suborno. Formaremos um exército de pioneiros para que os mercenários tenham vergonha de se aproximar daqui. 
O regime democrático, dentro desse esquema de princípios, funcionará em minha terra, e peço a Deus que sempre me ilumine para que não me faltem forças, através de esforço conjugado ao dos meus conterrâneos, para conduzir nosso barco até o fim.

Acreanos: se atentarmos para a trajetória que o Acre tem percorrido desde a sua incorporação até a presente data, verificaremos, sem prevenções ou má fé, excluindo mesmo os desmandos conscientes de certos administradores, com o seu cortejo de malversações e falcatruas, que o trabalho nesta nesga sempre fugiu à planificação e à faina de equipe. Trabalho desordenado, caracterizando-se pela vidade dos tons nitidamente pessoais, forjados ao calor de interesses imediatistas - esse trabalho teria que exprimir um acervo ridículo de obras isoladas, a maioria sem nenhum sentido prático, já que os problemas fundamentais do meio permaneciam intocáveis, vislumbrados apenas como se fossem fantasmagorias aterrorizantes. Se alguns assuntos chegavam a ser equacionados, depois de anos de discussões estéreis, esqueciam-se de que o povo carecendo de educação e saúde, não tinha sequer o que comer. Não havia sombra de um esforço consciente no sentido de enfrentar esse problema fundamental, sem o que a sociedade será sempre constituída de um povo desgraçado. Praticou-se sempre no Acre a forma mais negativa e primária de agricultura extensiva. $\mathrm{O}$ principal, que fosse a extração do látex que há havia dado ao Brasil figurar como o maior produtor de borracha do mundo mas que já havia descido à condição de um dos últimos produtores. A monocultura era um terço marcante da economia regional, encravado em condições geograficamente desfavoráveis, onde a única via de comunicações se representava pelos meandros dos rios do Acre.

Queremos, na qualidade de acreanos que sentimos diretamente as penúrias dos nossos conterrâneos; queremos, filhos desta terra cujo bem-estar saberemos colocar acima dos nossos próprios interesses dizer "basta"! a esses métodos retrógrados e irracionais, procurando, mais 
uma vez, colocarmo-nos à altura do nosso tempo, embora que, para isto, tenhamos que destruir inúmeros tabus.

Através da Secretaria de Agricultura do Estado, faremos elaborar um plano de Emergência, dentro das nossas reais possibilidades, objetivando a produção agrícola em alta escala, promovendo a baixa do preço de custo de feijão, arroz, milho, tubérculos e hortaliças. Na pecuária, merecerá nossa atenção, inicialmente, a criação de bovinos, suínos e aves, bem como a criação de peixes.

No setor de indústrias rurais objetivaremos a preparação, conservação e industrialização dos produtos agropecuários e, com relação ao ensino agrícola, dispensaremos toda colaboração à Secretaria de Educação a fim de que seja organizado e venha a funcionar a especialização de tal ensino.

A finalidade precípua do plano de Emergência refere-se à dinamização das atividades da Secretaria de Agricultura, no sentido de ser atingido o fim desejado no que concerne à produção de gêneros alimentícios, que ainda é insuficiente no Estado do Acre, mesmo para atender ao consumo de sua própria população.

Está caracterizada essa insuficiência pelo alto custo dos produtos alimentícios de primeira necessidade que vem sendo importados de outros Estados, quando o custo dos mesmos poderia ser muito mais baixo se fossem produzidos no Acre, o que tem acarretado, inclusive, a sangria, sempre crescente, de nossa economia financeira.

Essa situação, que se nos afigura aflitiva e para todo o povo acreano, é resultante, naturalmente, da falta de planejamentos anteriores mais efetivos que tivessem promovido um verdadeiro desenvolvimento da parte agropecuária, sem detrimento da indústria extrativa na borracha - principal fonte de renda do governo, levando-se em conta que $80 \%$ da população vive no meio rural. 
Em face disso, esperamos com o cumprimento deste plano de Emergência venha mudar inteiramente essa situação, oferecendo melhores condições de vida a este povo sacrificado.

Cumpre-nos fazer um serviço de recuperação do solo nas colônias de Rio Branco, que constituirão uma das futuras zonas de abastecimento da cidade, de forma a desenvolver a agricultura, paralelamente à pecuária ali dominante. Essa pecuária, no entanto, encontra-se ainda eficiente, tendo em vista a necessidade do consumo do Estado. Para se corrigir essa deficiência, é necessário dividi-la em pecuária de leite e de corte, reservando-se à primeira uma área não superior a 8 quilômetros em torno da Capital e das principais cidades, para facilitar o transporte do leite no tempo das chuvas.

Cumpre-nos, pois, em síntese, neste setor, melhorar a qualidade dos rebanhos e das pastagens, industrializar o leite e manter um serviço organizado de defesa sanitária animal.

Simultaneamente deverão ser desenvolvidas a suinocultura, avicultura, psicultura, e a criação de caprinos e ovinos em determinados casos.

Cumpre-nos dar toda a assistência necessária às colônias das zonas de abastecimento, sem, entretanto, deixar de dispensar a cooperação possível à grande família acreana ruralista, localizada fora das áreas mencionadas.

Cumpre-nos, finalmente, garantir a conservação, o beneficiamento e industrialização dos produtos agropecuários.

Em face do nosso planejamento racional, feito tendo como base a dura realidade da situação atual, acreditamos ser possível elevar o padrão alimentar do homem acreano, que no momento, infelizmente, se apoia numa ração diária em que o leite entre como um alimento básico com menos de 30 gramas "per capita", enquanto nas capitais de São Paulo e do Rio Grande do Sul a média é de 192 a 211 gramas, muito embora se considere para padrão internacional, ótimo, 450 a 500 gramas. 
Acresce-se ao deficiente consumo do leite e de seus derivados a insuficiência de frutas e hortaliças que vem sendo um dos fatores negativos para a saúde do povo, como prova, mesmo, a crescente incidência de tuberculose.

Achamos que cabe ao governo a responsabilidade da solução dos problemas agropecuários existentes, e conseqüentemente a solução, também, dos problemas alimentares de seu povo, na contingência atual.

As medidas preliminares de nosso plano, seguir-se-ão outras de longo alcance, como incentivar o plantio de castanheiras, de acordo com a melhor técnica, com aproveitamento e conseqüente industrialização da castanha do Pará; a recuperação dos cafezais acreanos, com beneficiamento no próprio local da colheita; incentivo ao plantio do algodão, dendê e o respectivo beneficiamento, bem assim do coqueiro da praia.

E, finalmente, terão especial atenção de nossa parte os produtos que resultem da indústria extrativa que possam representar fontes de renda para o Estado.

Estabelecemos como o objetivo constante e compulsório do Governo do Estado sem o que serão inconsistentes e frágeis outros quaisquer anseios de progresso - a elevação sistemática dos níveis educacionais da população acreana. Não será essa, evidentemente, tarefa simples, elementar e fácil; mas responsabilidade de extrema delicadeza, que exige, inclusive, aptidões e escrupulosa técnica para reformar, com propriedade, a filosofia, os métodos e os próprios critérios tradicionais de distribuição de ensino, pois as formas adotadas, até o momento, já não atendem às solicitações do desenvolvimento da área, como também não se ajustam - o que por certo será ainda de maior gravidade - às imposições e contingências do plano nacional de educação.

Torna-se imperioso, portanto, se quisermos algo de sério, respeitável e permanente, que o Governo submeta sempre a inventários e estudos rigorosos à aplicação dos recursos estaduais e os que lhe forem distribuídos pelos órgãos da União para que esse esforço de 
melhorar a educação do povo alcance realmente rentabilidade plena e ofereça oportunidades iguais aos moços desta terra para que a dignifiquem e honrem em termos que consolidem e ultrapassem as conquistas do passado.

Visamos, de início, para materializar tal programa:

a) - promover a escolarização gradativa e total das crianças acreanas entre sete e quatorze anos de idade. E que esse esforço não se circunscreva às sedes municipais do Estado: alcance beneficiar e proteja também os filhos desses homens extraordinários que sofrem e suam no interior das matas para ampliar e fortalecer as bases econômicas do desenvolvimento do Acre;

b) - para os adolescentes egressos do currículo primário estará o Governo permanentemente preocupado em abrir amplas oportunidades educacionais nos estabelecimentos do ensino médio, criando e reequipando os cursos ginasial, científico, colegial, normal, técnico comercial e industrial-agrícola, a estes últimos cuidado de assegurar também aproveitamento profissional em novas frentes de trabalho;

c) - para o ensino superior - aquele que permitirá a renovação dos quadros de liderança na sociedade acreana - várias alternativas se encontram em cuidadoso e planejado estudo. Sua última etapa há de ser a Universidade do Acre. Preliminarmente, entretanto, os nossos esforços estarão empenhados na criação de uma Faculdade de Filosofia, Ciências e Letras e na obtenção e crescente aumento de bolsas de estudos nas escolas superiores do país.

Esses, minhas Senhoras, meus Senhores, são os objetivos básicos e diretos que o Governo do Acre se propõe a disciplinar e dirigir durante o seu mandato, no campo da educação da coletividade. Mas devotamos também o máximo carinho aos projetos e iniciativas de suporte ou expansão do plano educacional do Governo. Tais, por exemplo, os programas que visem melhorar os índices de nutrição do escolar acreano, que dilatem, através de bibliotecas e de unidades de ensino audio-visual o ensino ministrado nos currículos, 
sistematizem e difundam o Ministério da Educação de Adultos, que exaltem as tradições cívicas e aprimorem os valores do espírito.

Todos esses programas finalmente visando edificar no Acre um modelo de educação brasileira, harmoniosamente ajustado as realidades da geocultura amazônica - passam a constituir, a partir desta data, os alvos fundamentais do Governo e de que dependerão, pelo menos em termos de perenidade, todos os demais objetivos que, também, neste instante, iremos projetar para o futuro.

No setor de Saúde Pública, acreanos, a terra está carecendo de quase tudo. As nossas populações do interior e, mesmo da Capital, sentem na própria carne as conseqüências do completo abandono em que sempre viveram e atualmente vegetam, implorando, numa percentagem irrisória se levarmos em conta o grosso dos nossos habitantes, uma passagem na FAB com destino a outros centros, principalmente o Rio de Janeiro, onde chegam miseráveis e famintos, alguns implorando a caridade pública. Digo isto porque, durante anos lidei com milhares desses seres humanos, que a falta de idealismo e visão administrativa de robustos administradores, se viam a braços com a doença e a miséria.

Também neste setor empenharemos grandes reservas de nossas energias, envidando esforços para que, no menor prazo de tempo possível possamos recuperar nossa rede hospitalar, destacando o serviço de Profilaxia da Tuberculoso que se nos apresenta como um dos mais graves problemas de saúde do Estado. A conclusão das obras e aparelhamento do Hospital para Tuberculosos, impõe-se às condições do regime de maior urgência. Apoio integral ao serviço de Profilaxia da Lepra e conclusão dos leprosários já iniciados. Incentivo à campanha de Erradicação da Malária, no que diz respeito às endemias rurais e dar às cidades acreanas condições sanitárias, partindo dos pontos básicos relativos aos serviços de água e esgotos. Dar assistência médica rural, levando o médico ao campo, e fazer funcionar, 
efetivamente, os Postos de Saúde do Estado. Dar, particularmente, assistência médica à infância, concluindo, em curto prazo, o Hospital Infantil.

Em síntese, meus senhores, o programa a que nos obrigamos, neste setor de Saúde Pública, nada tem de mirabolante, mas é um programa sério ditado pelas reais necessidades de um meio onde está quase tudo por fazer. Iremos a ele com o mesmo idealismo, com a mesma energia, e certos estamos de que contaremos com a boa vontade do nosso povo indomável.

No que tange ao setor propriamente de Obras, nossos esforços serão também ingentes. Claro que se trata de um setor de trabalhos mais concretos, subordinados em suas finalidades, a programas elaborados por diversos outros setores da pública administração, como Agricultura, Educação e Saúde. Mas terá, também, independentemente, um acervo bem grande de trabalhos a serem concluídos e iniciados, como asfaltamento de ruas, recuperação de prédios já existentes e em execução; construção de estradas rurais e asfaltamento das que ligam Rio Branco às principais colônias agrícolas. Construção da estrada Rio Branco x Porto Acre x Boca do Acre; Rio Branco x Vila Plácido de Castro; Rio Branco x Paraguassu; Rio Branco x Sena Madureira; Feijó x Tarauacá, bem como a ligação da cidade de Cruzeiro do Sul à Pucalpa (Peru) e ao Japiim. Construção, dentro do plano educacional e da Secretaria de Agricultura, de escola de Iniciação Agrícola, rede hospitalar e casas residenciais para funcionários, esta parte já em execução. Aproveitamento do potencial de cachoeiras localizadas no rio Ituxi, que já sobrevoamos, para observação da lâmina d'água das cachoeiras. A pista de pouso internacional e a Ponte sobre o rio Acre.

Aqui está, meus senhores, minhas senhoras, uma súmula daquilo que pretendemos realizar para o Acre e os seus filhos. Embora nos esforcemos, através destas frases despretensiosas, no sentido de elaborar um trabalho de síntese, damos, aqui, uma idéia do que nos propormos concretizar. Não julguem alguns, pelo simples ouvir, sobretudo os que se deixaram contaminar por um pessimismo que corrói as fibras d' alma, que os nossos planos 
sejam inexeqüíveis. Mas nós sabemos também compreender o estado d' alma daqueles que, deixando-se esmagar por experiências desalentadoras nesta terra, por força de circunstâncias adversas, foram arrastados pela torrente devastadora dos negativismos pessoais. E se quedam, depois, à margem da estrada, ociosos, vendo a vida passar. Mas, o brado do grande de William Shakespeaer ainda prevalecerá, temos certeza, para a esmagadora maioria dos filhos desta terra: "A ociosidade engendra os covardes. O homem forte nasce da luta", ou os versos do nosso imortal Gonçalves Dias: “A vida é luta renhida, viver é lutar".

Se o grande combate

Os fracos abate

Aos fortes, aos bravos

Só pode exaltar.

Povo acreano:

Antes de encerrar minhas palavras não me posso furtar ao ensejo de asseverar aos meus conterrâneos que, também, não medirei esforços a fim de que Administração Pública no Acre se realize como um exemplo de lisura, expressa através da honorabilidade Pública dos homens sobre os ombros dos quais recaem responsabilidades. No setor das Finanças, o Código de Contabilidade norteará os trabalhos dos nossos administradores, para que a Administração do Estado venha a possuir, realmente, uma contabilidade Pública. Conto ainda, para isto, com acreanos competentes e honestos que o nosso povo receberá de braços abertos, convictos de que um dos seus grandes anseios será realizado em nossa terra.

Minhas Senhoras, meus senhores: escusado é dizer da minha forte emoção e subida honra ao penetrar este recinto, receber o Diploma que o povo acreano me conferiu e entrar em contato com os nobres representantes do povo em sua própria casa, bem como as autoridades 
aqui presentes e, particularmente, com o Governador do Departamento Pando e sua comitiva, da vizinha e amiga República da Bolívia, e os dignos emissários dos governos estaduais que se fizeram aqui representar. Enorme, senhores representantes do povo, irmãos na Democracia, é a missão que o povo vos confia nesta etapa singular do histórico político-administrativo da Placilânida.

Tenho fé em vosso idealismo e no vosso propósito inquebrantável de defender o nosso povo em suas reivindicações, como um Poder consciente e elevado, harmônico com os demais na salvaguarda da Democracia e na defesa intransigente do nosso indômito povo, sobretudo dos mais humildes. Junto marchamos para mostrar ao Brasil que o regime democrático vive agora no Acre, e que o seu pulso é firme. Acredito em vós, ó! Dignos Deputados do povo, na vossa intenção elevada, no vosso desprendimento, na confiança que há de crescer mais ainda entre vós e os filhos da terra de Plácido de Castro. Senhores Deputados, muito obrigado.

Agradeço, ainda, sensibilizado, o comparecimento de todos aqueles que me honraram nas festividades e solenidades, programadas para minha posse, o que me alicerça ainda mais, pelo apoio que esse gesto simboliza, o sentimento de confiança em nossa brava gente e a certeza de que conto com o povo para o cumprimento sagrado de meu desiderato. Particularmente àqueles que se deslocaram de outros Estados, ao Poder Judiciário aqui presente, e ao mui digno Governador do Departamento Pando, da República irmã da Bolívia - que este momento represente o selo em nossos laços de fraterna e indissolúvel amizade, sentimento que tem caracterizado substancialmente os entendimentos entre o Brasil e a grande Pátria de Simon Bolivar.

Senhores Deputados; minhas senhoras; meus senhores; glorioso povo acreano, mais uma vez, muito obrigado!

Pelo progresso do Acre! Pela crescente consolidação da Democracia em nossa Pátria! Tudo pela grandeza do Brasil." 


\begin{abstract}
ANEXO E
CONSTITUIÇÃO DO ESTADO DO ACRE *

TÍTULO I
\end{abstract}

Da Organização do Estado

CAPÍTULO I

Dos Poderes

SEÇÃO ÚNICA

\title{
Disposições Fundamentais
}

Art. $1^{\circ}$ O Estado do Acre, parte integrante da Federação Brasileira, com os limites geográficos do Território que the deu origem, reger-se-á pela presente Constituição e leis que adotar.

Art. $2^{\circ}$ São Poderes do Estado: o Legislativo, o Executivo e o Judiciário, independentes e harmônicos entre si.

$\S 1^{\circ}$ - Ressalvadas as exceções previstas nesta Constituição, o cidadão investido nas funções de um dos Poderes não pode exercer as de outro.

$\S 2^{\circ}$ - É vedado a qualquer dos Poderes delegar atribuições.

Art. $3^{\circ}$ A cidade de Rio Branco é a Capital do Estado.

\section{CAPÍTULO II}

\section{Do Poder Legislativo}

* * MESQUITA JÚNIOR, Geraldo. Constituições do estado do Acre. Brasília: Senado Federal, 2003, p. 19-40. 


\section{SEÇÃO I}

\section{Da Assembleia Legislativa}

Art. $4^{\circ}$ - O Poder Legislativo é exercido pela Assembleia Legislativa composta de, no mínimo, 15 (quinze) representantes do povo, eleitos simultaneamente com o governador.

§ I O número de deputados, nunca inferior ao estabelecido neste artigo, será fixado em lei, na proporção de l (um) para cada 15.000 (quinze mil) habitantes, até o limite de 30 (trinta), quando a mesma passará a ser de l (um) para cada 30.000 (trinta mil) habitantes.

$\S 2^{\circ}$ A legislatura terá duração idêntica à da Câmara Federal.

$\S 3^{0^{\circ}}$ A Assembleia reunir-se-á na capital do Estado de 7 de março a 30 de junho e de $1^{\circ}$ de agosto a $1^{\circ}$ de dezembro, salvo prorrogação ou convocação extraordinária. ${ }^{\prime}$

$\S 4^{\circ}$ A Assembleia Legislativa poderá ser convocada, extraordinariamente, por iniciativa de 2/3 (dois terços) de seus membros ou pelo governador, com declaração do motivo, restringindo-se as deliberações ao assunto que for objeto da convocação.

$\S 5^{\circ}$ Na composição das Comissões e da Mesa assegurar-se-á, tanto quanto possível, a representação proporcional dos partidos.

$\S 6^{\circ}$ A Assembleia Legislativa criará Comissões de Inquérito sobre ocorrência determinada, sempre que o requerer 1/3 (um terço) de seus membros, observado o critério do parágrafo anterior.

Art. $5^{a}$ São condições de elegibilidade para a Assembleia Legislativa: I - ser brasileiro (art. ${ }^{a}$ 129, números I e II da Constituição Federal);

\footnotetext{
${ }^{1}$ Redação dada pelas Emendas Constitucionais no 5 e 6/66. Redação original: s $3^{\circ}$ - A Assembléia reunir-se-á na capital do estado, de 15 de março a 15 de dezembro, salvo prorrogação ou convocação extraordinária.
} 
II - estar no exercício dos seus direitos civis e políticos;

III - Ser maior de 21 (vinte e um) anos.

Art. $6^{\circ}$ A Assembleia funcionara, em sessões públicas ou secretas, com a presença de, pelo menos, 1/3 (um terço) dos Deputados e se poderá deliberar com a manifestação da maioria absoluta de seus mem bros.

\section{Art. $7^{0}$ - Compete à Assembleia Legislativa:}

I - elaborar seu Regimento Interno, dispor sobre a organização de seus serviços, inclusive Polícia, criação e provimento de cargos em seu quadro;

II - dar posse ao governador eleito, conhecer da sua renúncia e conceder-lhe ou não licença para ausentar-se do estado por mais de 30 (trinta) dias;

III - apreciar os vetos;

IV - julgar objeto de deliberação a denúncia contra o governador e os Secretários de Estado e decretar a procedência da acusação, nos crimes de responsabilidade;

V - indicar ao governador, em lista tríplice, o Auditor-Geral;

VI - suspender, no todo ou em parte, a execução de qualquer lei ou ato do Poder Público declarado inconstitucional;

VII - julgar, no curso da sessão legislativa em que forem recebidas, as contas do governador, relativas ao exercício anterior;

VIII - fixar, no último ano da legislatura, os vencimentos do Governador e dos Secretários de Estado, bem como os subsídios e ajuda de custo dos deputados;

IX - estabelecer e mudar o local de suas reuniões;

X - propor emenda à Constituição Federal e emendar esta Constituição;

XI - autorizar a celebração de acordos e convénios pelo governador, com a União, outro Estado ou Município, e ratificar, ou não, os que, por motivo de imperiosa urgência, forem realizados sem prévia autorização; 
XII - aprovar ou suspender a intervenção nos municípios, quando decretada pelo governador;

XIII - conceder ou negar licença para que seus membros sejam processados criminalmente;

XIV - criar Comissões de Inquérito;

XV - convocar Secretários de Estado, fixando dia e hora para comparecimento;

XVI - resolver sobre a incorporação, anexação, subdivisão ou desmembramento do território do Estado, nos termos da Constituição Federal;

XVII - decretar a perda do mandato do deputado que proceder de forma incompatível com o decoro parlamentar.

Art. 8 Compete à Assembleia Legislativa, com a sanção do governador.

I - legislar sobre todas as matérias, dentro dos limites fixados pela Constituição Federal;

II - dispor sobre a dívida pública estadual e autorizar o governador a contrair empréstimos internos e a realizar operações de crédito;

III - fixar o efetivo da Polícia Militar;

IV - mudar, temporariamente, a Capital do Estado;

V - votar o orçamento;

VI - alienar, ceder, arrendar, adquirir ou desapropriar imóveis.

\section{SEÇÃO II}

\section{Dos Deputados}

Art. $9^{\circ}$ Os deputados são invioláveis, no exercício do mandato, por suas opiniões, palavras ou votos.

Art. 10. Depois de diplomado e até o início da legislatura seguinte, nenhum deputado poderá ser preso, salvo em flagrante de crime inafiançável, nem processado criminalmente, sem prévia licença da Assembleia. 
Parágrafo único. A prisão em flagrante será, incontinenti, comunicada ao Presidente da Assembleia e o respectivo auto ser-lhe-á enviado dentro de 48 (quarenta e oito) horas, a fim de que esta decida quanto à prisão e autorize ou denegue a formação da culpa.

Art. 11. Os impedimentos constantes dos incisos I e II, do art. 48, da Constituição Federal, são extensivos aos Deputados Estaduais.

Art. 12. Mediante provocação de qualquer de seus pares, de Partido Político ou do Procurador-Geral e por decisão da Assembleia, perderá o mandato o deputado:

I - por infração ao disposto no artigo anterior;

II - no caso de falta às sessões, por 60 (sessenta) dias consecutivos;

III - pelo procedimento incompatível com do decoro do mandato.

Art. 13. É permitido ao deputado, independentemente de licença da Assembleia:

I - exercer cargo de magistério provido por concurso;

II - afastar-se temporariamente, do exercício do mandato para exercer as funções de Ministro de Estado, Interventor Federal ou Estadual, Secretário de Estado ou missão oficial do Governo Federal no Exterior,

§l’ Será convocado o suplente do deputado nos casos de vaga por:

I-falecimento;

II - renúncia expressa;

III - perda de mandato;

IV - licença superior a 60 (sessenta) dias;

$V$ - afastamento previsto no inciso II deste artigo.

$\S 2^{\circ}$ Ocorrendo vaga e não havendo Suplente, o Presidente da Assembleia comunicará o fato, no prazo de 48 (quarenta e oito) horas, ao Tribunal Regional Eleitoral, que marcará eleição para o preenchi- 
mento, salvo se faltar l (um) ano para o término da legislatura. O deputado eleito exercerá o mandato pelo tempo restante.

Art. 14. Os deputados perceberão ajuda de custo anual e substituto mensal fixados em cada legislatura para a subsequente. O subsídio dividi-se em duas partes: uma fixa, paga no decurso de todo o ano e outra variável correspondente aos comparecimentos. ${ }^{2}$

Parágrafo único. Os deputados não podem perceber, a qualquer titulo, remuneração superior a $2 / 3$ do que percebem os deputados federais. ${ }^{3}$

\section{SEÇÃO III}

\section{Das Leis e Resoluções}

Art. 15. A iniciativa das leis, inclusive as que dispuserem sobre matéria financeira, cabe a qualquer deputado ou Comissão da Assembleia Legislativa e ao governador. ${ }^{4}$

$\S$ I $^{\circ}$ - Ressalvada a competência da Assembleia e do Tribunal de Justiça no que concerne aos respectivos serviços administrativos, compete exclusivamente ao governador a iniciativa das leis que criam

Cargos, funções ou empregos públicos aumentar vencimentos ou despesa pública, e dispondo sobre anexação do efetivo da Polícia Militar do Estado. 5

- Aos projetos dessa competência exclusiva do governador devem estar, não serão admitidas emendas que aumentem a despesa prevista. 6

$\S 3^{\circ}$ A discussão e votação dos projetos de iniciativa do governador devem estar concluídas dentro de 45 dias, a contar de seu recebimento. ${ }^{6}$

\footnotetext{
${ }^{2}$ Redação dada pela Emenda Constitucional, n ${ }^{o}$ 4/65, de 1/12/65. Redação anterior: "Os dependentes vencerão, anualmente, subsídio e ajuda de custo."

${ }^{3}$ Redação dada pela Emenda Constitucional no 4/65, de 1/12/65. Redação anterior: "A iniciativa das leis, ressalva dos os casos de competência exclusiva, caabe ao governador e a qualquer membro ou Comissão de Assembléia.

${ }^{4}$ Redação dada pela Emenda Constitucional,, $n^{\mathrm{o}}$ 4/65. Redação anterior: "A iniciativa das leis ressalvados os casos de competência exclusiva, cabe ao governador e a qualquer membro ou Comissão da Assembléia. financeiros."
} 
$\S 4^{\circ}$ O governador, se julgar urgente a medida, poderá solicitar que apreciação do Projeto se faça em 30 dias. Se julgar, por outro lado, que o projeto não sendo urgente, merece maior debate pela extensão de seu texto solicitará que sua apreciação se faça em maior prazo. ${ }^{<<}$

§ 5- Não apreciados dentro dos prazos previstos no parágrafo anterior, os Projetos serão todos como aprovados, com texto original da Mensagem Governamental. ${ }^{<\triangleleft}$

Art. 16. A Assembleia deliberará:

I - por maioria de votos, presente a maioria absoluta de seus membros, nos casos que não estejam sujeitos a quorum especial;

II - por 2/3 (dois terços) dos membros presentes, sobre a aprovação de projetos vetados;

III - por maioria absoluta de votos;

a) para julgar objeto de deliberação a denúncia contra o Governa dor e secretários de estado;

b) sobre projetos que criem cargos e funções ou, salvo o orçamento, aumentem a despesa pública, exceto em caso de guerra, comoção intestina ou calamidade pública;

5. Redação dada pela Emenda Constitucional, $n^{\circ}$ 4/65, de 1/12/65. Redação anterior: "As leis que aumentem vencimentos ou proventos de qualquer natureza ou modifiquem os quadros dos servidores públicos, inclusive da Polícia Militar; dependerão sempre, para a sua execução de prévia atribuição e destinação de recursos financeiros".

6. Dispositivo acrescentado pela Emenda Constitucional , $\mathrm{n}^{\mathrm{o}}$ 4/65, de 1/12/65.

c) sobre transferência e isenção de impostos;

d) sobre a criação de municípios, subdivisão ou desmembramento do Estado ou Município, assim como incorporação do território, no todo ou em parte, a outro Estado, ou formação de novo estado. 
IV - por 2/3 (dois terços) de seus membros;

a) para decretar a procedência de acusação, nos crimes de responsabilidade do governador e secretários de estado;

b) para a aprovação de projetos relativos a favores e benefícios a pessoa física ou jurídica de direito privado;

c) sobre alteração do número de deputados, quando na mesma legislatura;

d) para declarar a perda de mandato do deputado.

Parágrafo único. A votação será secreta nos casos estabelecidos no Regimento Interno e, obrigatoriamente, para:

I - eleição da Mesa;

II - deliberação sobre veto;

III - aprovação das contas do governador;

IV - resolução sobre prisão e processo de deputados;

$\mathrm{V}$ - perda de mandato de deputados;

VI - aprovação de indicações pela Assembleia;

VII - decretar a procedência da acusação, nos crimes de responsabilidade.

Art. 17. Os projetos de lei e de resolução serão submetidos a duas discussões e votações.

$\S 11^{\circ}$ Será dispensada a segunda discussão e votação, quando na primeira o projeto for aprovado pelo voto de 2/3 (dois terços) dos membros da Assembleia.

$\S 2^{\circ} \mathrm{O}$ projeto aprovado, quando depender de sanção, será enviado ao governador, que o sancionará ou vetará no prazo de $10(\mathrm{dez})$ dias. Decorrido o decénio, o silêncio do governador importará em sanção e o Presidente da Assembleia promulgará a lei, em 48 (quarenta e oito) horas, neste caso e no de rejeição do veto.

$\S 3^{\circ}$ As leis de competência exclusiva da Assembleia serão promulgadas e mandadas publicar pelo seu presidente. 
$\S 4^{\circ}$ Os projetos de lei rejeitados, inclusive por efeito de manutenção de veto, somente poderão renovar-se na mesma sessão legislativa quando subscritos pela maioria dos membros da Assembleia.

\section{SEÇÃO IV}

\section{Do Veto}

Art. 18. O governador julgando o projeto inconstitucional ou contrário aos interesses do Estado, poderá vetá-lo total ou parcialmente, dentro de prazo de $10(\mathrm{dez})$ dias, contados da data em que o receber, devolvendo-o com as razões do veto ao Presidente da Assembleia.

$\S 1^{\circ}$ Independente da deliberação sobre a matéria vetada, à parte sancionada do projeto entrará imediatamente em vigor.

$\S 2^{\circ}$ A matéria vetada será apreciada em discussão única, após relatório da Comissão competente.

$\S 3^{\circ}$ Considerar-se-á aprovado o projeto de lei vetado que obtiver sufrágio de 2/3 (dois terços) dos deputados presentes.

$\S 4^{\circ} \mathrm{O}$ veto parcial não poderá ser utilizado em relação a palavras ou algarismos de artigo, parágrafo, inciso ou alínea.

\section{SEÇÃOV}

\section{Das Emendas à Constituição}

Art. 19. A Constituição poderá ser emendada.

$\S 1^{\circ}$ Considerar-se-á proposta a emenda se for apresentada pela terça parte, no mínimo, dos membros da Assembleia, ou por mais da metade das Câmaras Municipais no decurso de duas sessões legislativas, manifestando-se cada uma delas pela maioria de seus componentes. 
$\S 22^{\circ}$. Dar-se-á por aceita a emenda que for aprovada em duas discussões pela maioria absoluta da Assembleia, em duas sessões legislativas ordinárias e consecutivas.

$\S 3^{\circ}{ }^{\circ}$ Se a emenda obtiver em duas discussões, na mesma sessã legislativa, o voto de $2 / 3$ (dois terços) dos membros da Assembleia, dar se-á por aceita.

$\S 4^{\circ}$. A proposta não poderá ser emendada, salvo antes da pn meira votação.

$\S 5^{\circ}{ }^{\circ}$ Não se emendará a Constituição na vigência do estado de sítio, ou de intervenção federal.

$\S 6^{\circ}$. Quando houver modificação da Constituição Federal, que importe em alteração desta Constituição, sua revisão poderá ser feita em uma só sessão legislativa, se aprovada pela maioria absoluta da Assembleia.

$\S l^{\circ}$ Promulgada pela Mesa da Assembleia, a emenda será incorporada ao texto desta Constituição, com o respectivo número á ordem.

\section{SEÇÃO VI}

\section{Do Orçamento}

Art. 20. O orçamento observará, além do disposto nos arts. 73 a 75 da Constituição Federal, os preceitos seguintes:

I - a proposta orçamentaria, remetida à Assembleia até o dia 31 de julho, será elaborada sob a direção do Secretário de Estado competente, e condicionar-se-á aos planos de ação do Poder Executivo;

II - a lei poderá ordenar ou autorizar a transferência de créditos orçamentados ou adicionais, sem aumento de despesa, de um fim para outro, assim como a abertura de créditos extraordinários, se ocorrer qualquer dos casos previstos no parágrafo único do art. 75 da Constituição Federal;

III - serão obrigatoriamente incluídas na despesa, as dotações previstas em programas plurianuais aprovados por lei.

IV - serão incluídas no orçamento a estimativa da receita e a previsão da despesa de quaisquer órgãos autónomos e empresas patrimoniais, comerciais ou industriais do estado; 
V - a proposta deverá exprimir, qualitativa e quantitativamente, os fins definidos e concretos, por alcançar em cada despesa, aplicando-se ao orçamento norma idêntica;

VI - a mensagem que encaminhar a proposta orçamentaria deverá mencionar, em bases de contabilidade económica, os objetivos fiscais e os presumíveis efeitos da política financeira;

VII - na despesa variável, destinar-se-á uma dotação, nunca inferior a 10\% (dez por cento) da receita tributária, para cobertura dos créditos adicionais que vierem a ser abertos no curso do exercício;

VIII - as leis de criação ou majoração de tributos, para execução no exercício imediato, serão anteriores ao orçamento e neste constará a autorização prévia para a sua cobrança, nos termos do art. 141, $\S 34$ da Constituição Federal;

IX - não se autorizará a abertura de créditos suplementares antes de decorrido o primeiro semestre do exercício;

$\mathrm{X}$ - todo aumento de despesa, além do crescimento vegetativo médio da receita no triénio anterior, só será computado nos créditos orçamentários e adicionais se for decretada a majoração proporcional das alíquotas dos impostos que devem cobrir os gastos respectivos;

XI - se até o dia 31 de julho não for enviada a proposta orçamentaria, passará a ser considerado, para discussão, o orçamento vigente;

XII - o estado não despenderá com o seu funcionalismo mais de 40\% (quarenta por cento) de suas rendas.

\section{SEÇÃO VII}

\section{Da Fiscalização Orçamentaria}

Art. 21. A Auditoria-Geral de Contas, órgão auxiliar do Poder Legislativo na fiscalização da execução orçamentaria e da administração financeira do Estado, tem por chefe o Audiíor-Geraí, e escolhido pelo Governador em lista tríplice, feita pela Assembleia, dentre brasileiro maiores de 30 (trinta) anos, no exercício dos seus direitos civis e políticos e de notórios conhecimentos financeiros. 
$\S 1^{\circ} \mathrm{O}$ Auditor-Geral terá os vencimentos, direitos, vantagens, impedimentos e incompatibilidades dos Secretários de Estado.

$\S 2^{\circ} \mathrm{O}$ Auditor-Geral terá assegurado o exercício de seu mandato pelo prazo de 4 (quatro) anos, podendo o mesmo ser extinto, a qualquer tempo, por decisão da Assembleia, aprovada por maioria absoluta.

$\S 3^{\circ}$ Ocorrendo à hipótese prevista no parágrafo anterior, a Assembleia procederá na forma do art. 21 desta Constituição, devendo o novo escolhido exercer o seu mandato pelo prazo previsto no $\S 2$ deste artigo.

Art. 22. Compete ao Auditor-Geral:

I - acompanhar e fiscalizar, diretamente ou por delegados e subordinados, a execução orçamentaria, ordenando quaisquer diligências in loco;

II - cumprir as instruções da Assembleia;

III - emitir parecer sobre as contas dos responsáveis por dinheiros e outros bens públicos, bem como sobre a legalidade dos contratos, aposentadorias, reformas e pensões quanto aos respectivos registros;

IV - praticar, em relação ao seu pessoal, aios de administração;

$\S l^{5}$ Os contratos que, por qualquer modo, interessarem à receita ou à despesa, só serão considerados perfeitos depois de registrados previamente pela Auditoria-Geral de Contas. A recusa do registro suspenderá a execução do contrato, até que a respeito se pronuncie a Assembleia.

$\S 2^{\circ}$ Será sujeito a registro prévio, pelo Auditor-Geral, qualquer ato de que resulte obrigação de pagamento pelo Tesouro Estadual ou por contadeste.

$\S 3^{\circ}$ A recusa do registro, por falta de saldo no crédito ou por imputação a crédito impróprio, terá caráter proibitivo. Quando a recusa tiver outro fundamento, a despesa poderá efetuar-se, após despacho do governador, com registro sob reserva pelo Auditor-Geral, que o comunicará à Assembleia. 
$\S 4^{\circ}$ O Auditor-Geral dará parecer prévio, no prazo de 30 (trinta) dias, sobre contas da gestão anual do governador. Se elas não lhe forem enviadas no prazo da lei, comunicará o fato à Assembleia, apresentando-lhe, num e noutro caso, relatório do exercício financeiro encerrado.

\section{CAPÍTULO III}

\section{Do Poder Executivo}

\section{SEÇÃOI}

\section{Do Governador}

Art. 23. O Poder Executivo é exercido pelo governador com a cooperação responsável dos Secretários de Estado.

$\S 1^{\circ}$ São condições de elegibilidade do Governador do Estado:

I - ser brasileiro nato (Constituição Federal, art. 129,1 e II);

II - estar no exercício dos direitos civis e políticos;

III - ser maior de 30 (trinta) anos.

$\S 2^{\circ}$ A eleição do Governador será realizada por sufrágio direto e majoritário, simultaneamente com a dos Deputados.

$\S 3^{\circ} \mathrm{O}$ governador tomará posse perante a Assembleia Legislativa ou, em caso de recesso desta, perante o tribunal Regional Eleitoral, prestando, no ato da posse, o seguinte compromisso:

"Prometo manter, defender e cumprir a Constituição e as leis da República e do Estado, servindo com honra, probidade e dedicação ao povo do Acre. "

$\S 4$ Será de 4 (quatro) anos o mandato do Governador, contados a partir da data da posse. $\S 5^{\circ}$ Aplicam-se ao governador os impedimentos previstos no art. 11 desta Constituição.

$\S 6^{\circ}$ O governador será substituído, provisória ou definitivamente, pelo:

I - Presidente da Assembleia; 
II - Presidente do Tribunal de Justiça;

III - Vice-Presidente da Assembleia;

IV - Vice-Presidente do Tribunal de Justiça.

Art. 24. Assumirá o cargo de governador o seu substituto legal, nos casos de:

I - vacância provisória do cargo:

a) por impedimento ocasional;

b) pela ausência, do território estadual ${ }^{(7)}$

II - vacância definitiva do cargo:

d) por falecimento;

ti) por renúncia expressa;

c) por perda dos direitos civis e políticos por prazo igual ou superior ao que restar do seu mandato;

d) pela infração do disposto no art. 11 desta Constituição;

e) quando não tomar posse na data designada pelo Tribunal Regional Eleitoral;

f) pela destituição, decretada pela Assembleia;

g) pela ausência superior a 30 (trinta) dias, sem licença da Assembleia, do território estadual;

h) pela incapacidade física ou mental, por mais de 6 (seis) meses, comprovada por junta médica;

O quando não tomar posse na data designada pela Assembleia;

7. A expressão "superior a 30 dias": foi suprimida pela Emenda Constitucional, no 1, de 28/11/63.

y) quando não assumir o exercício imediatamente após o término da licença.

$\S 1^{\circ}$ A vacância do cargo, prevista neste artigo, será declarada:

I - pelo Tribunal Regional Eleitoral, nos casos das letras a, b, c, d, e, do inciso II deste artigo; 
II - pela Assembleia Legislativa do Estado nos demais casos.

$\S 2^{\circ}$ No caso da vacância definitiva do cargo, verificada na primeira metade da legislatura, realizar-se-ão novas eleições, dentro de 90 (noventa) dias, exercendo o eleito o tempo que restar do mandato.

$\S 3^{\circ}$ No caso de vacância definitiva do cargo de Governador declarada pela Assembleia Legislativa, a eleição do novo Governador, para exercer o tempo que restar do mandato, será realizada pela maioria absoluta dos membros da Assembleia Legislativa, dentro de dois dias a contar da vacância em sessão pública e votação nominal. ${ }^{8}$

$\S 4^{\circ}$ Para eleição regulada neste artigo não haverá inelegibilidade..8

$\S 5^{\circ}$ O Governador eleito na conformidade das disposições deste ato exercerá um mandato até 31 de janeiro de $1967 .^{8}$

Art. 25. Compete, privativamente, ao Governador do Estado:

I - enviar mensagem à Assembleia, no início de cada sessão legislativa, dando-lhe conta da situação económica, administrativa, social e política do Estado;

II - sancionar ou vetar projetos, fazer publicar as leis e expedir decretos e regulamentos para sua execução;

III - nomear e exonerar, livremente, os Secretários de Estado;

IV - nomear, depois da indicação da Assembleia, o Auditor-Geral;

$V$ - prover, na forma da lei, os cargos públicos;

8. Redação acrescentada pela Emenda Constitucional , $n^{\circ} 3$, de 8/5/64.

VI - manter relações com o Congresso Nacional, o Presidente da República, os Ministros de Estado e os Governadores de outros Estados; 
VII - celebrar acordos e convénios com os órgãos da União, de outros Estados e Municípios, ad referendum da Assembleia Legislativa ou nos termos das autorizações previamente concedidas (art.7 $7^{a}$, inciso XI);

VIII - dispor da Polícia Militar e administrá-la, nos termos da lei; DC - enviar à Assembleia, até 31 de julho, a proposta orçamentaria;

$X$ - decretar a intervenção nos Municípios, ad referendum da Assembleia Legislativa, nos termos da Constituição Federal;

XI - prestar, anualmente, à Assembleia, dentro de 60 (sessenta) dias após o início da sessão legislativa, as contas relativas ao exercício

XII - prestar por escrito, dentro de 30 (trinta) dias, todas as informações que a Assembleia solicitar;

XIII - convocar, extraordinariamente, a Assembleia Legislativa, quando os interesses do Estado o exigirem;

XIV - praticar quaisquer atos de interesse do Estado;

XV - representar o Estado em Juízo, por intermédio dos Procuradores e Advogados do Estado;

XVI - representar ao Supremo Tribunal Federal, por intermédio do Procurador-Geral da República, contra leis e atos que violem os arts. $7^{\circ}$ e $8^{\circ}$ da Constituição Federal;

XVII - contrair empréstimo externo ou interno, após autorização da Assembléia Legislativa, observando, quanto ao primeiro, o disposto no art. 63, inciso II, da Constituição Federal.

$\S 1^{\circ}$ Sem prejuízo da competência da Assembleia Legislativa e do Tribunal de Justiça, no que se relaciona com os respectivos serviços administrativos, compete, exclusivamente, ao governador a iniciativa de lei que crie cargos e funções em serviços existente, aumentem vencimentos ou proventos 
qualquer natureza, ou modifiquem no curso da legislatura, o quadro e o efetivo da Polícia Militar ou de quaisquer corporações do Estado.

$\S 2^{\circ}$ Ressalvados os casos de competência privativa, previstos na Constituição ou em lei, é facultado ao governador, mediante decreto, delegar competência aos Secretários de Estado e dirigentes de órgãos descentralizados para assinar atos de administração.

\section{SEÇÃO II}

\section{Dos Secretários de Estado}

Art. 26. Os Secretários de Estado cooperarão com o governador na direção dos negócios públicos e a cada um deles incumbirá a responsabilidade dos serviços e unidade administrativa da respectiva Secretaria.

$\S 1^{\circ}$ São condições essenciais para a investidura no cargo de Secretário de Estado ;

I - ser brasileiro;

II - ser maior de 25 anos;

III - estar no exercício de seus direitos civis e políticos.

$\S 2^{\circ}$ Além das atribuições definidas em lei, compete ao Secretário de Estado:

I - executar, por meio dos serviços e unidades administrativas sob sua direção, de conformidade com a orientação geral do governador, o plano de Governo decorrente das leis e do orçamento;

II - referendar os atos do governador, pertinentes à sua Secretaria ou a todas as Secretarias, quando de ordem geral;

III - expedir instruções necessárias à fiel execução das leis e regulamentos;

IV - apresentar ao Governador, até 31 de janeiro de cada ano, relatório dos serviços a seu cargo;

V - organizar os elementos para a proposta orçamentaria de sua Secretaria; 
VI - comparecer perante a Assembleia ou a qualquer de suas Comissões, dentro de 8 (oito) dias a partir de sua convocação, ou na data que lhe for fixada, quando pedir para expor qualquer assunto ao Poder Legislativo.

$\S 3^{\circ}$ Os Secretários de Estado são responsáveis por seus atos, ainda quando praticados por ordem do governador ou conjuntamente com este.

$\S 4^{\circ}$ É facultado ao Secretário de Estado, mediante ato expresso e prévia autorização do governador, delegar competência a Diretores para assinar atos de administração.

Art. 27. O Governador do Estado, para um fim especial e só enquanto este durar, poderá nomear, até o máximo de 2 (dois), Secretários de Estado, sem pasta.

Art. 28. Aplicam-se aos Secretários de Estado os impedimentos previstos no art. 11 desta Constituição.

\title{
SEÇAO III
}

\section{Da Responsabilidade}

Art. 29. São crimes de responsabilidade do Governador e dos Secretários de Estado, quando por eles praticados, os atos definidos como tais pela Lei Federal $\mathrm{n}^{\mathrm{fl}} 1.079$, de 10 de abril de 1950 .

Parágrafo único. O processo e o julgamento dos crimes de responsabilidade são os determinados pela lei referida neste artigo.

\author{
CAPÍTULO IV
}

Do Poder Judiciário

SEÇÃOI 


\section{Dos Órgãos do Poder Judiciário}

Art. 30. O Poder Judiciário é exercido pêlos seguintes órgãos:

I - Tribunal de Justiça;

II - Juizes e Tribunais de primeira instância.

\section{SEÇÃO II}

\section{Do Tribunal de Justiça}

Art. 31. O Tribunal de Justiça, órgão de última instância do Poder Judiciário, com sede na Capital e jurisdição em todo o território do Estado, compor-se-á de cinco desembargadores, nomeados pelo governador, na forma prevista pela Constituição Federal. Esse número, mediante lei, por proposta do próprio Tribunal poderá ser elevado.

Art. 32. Compete ao Tribunal de Justiça:

I - privativamente:

a\} elaborar seu Regimento interno, eleger seu Presidente e demais membros de direção;

b) organizar os quadros da Justiça Estadual, secretaria do Tribunal e Serviços Auxiliares, Titulares de Ofícios e Serventuários da Justiça, provendo-lhes os cargos e funções;

c) propor as leis relativas ao Poder Judiciário e aos quadros da Justiça Estadual que criem ou extingam cargos $e$ funções, e que fixem ou aumentem, a qualquer título, os respectivos vencimentos, gratificações e vantagens.

II - processar e julgar, originariamente:

d) o Governador e os Secretários de Estado, nos crimes comuns;

b) o interventor nos Municípios, o Procurador-Geral, o Auditor-Geral, os Juizes de instância inferior e os membros do Ministério Público, nos crimes comuns e de responsabilidade; 
c) as causas e conflitos entre o Estado e seus Municípios, e os destes entre si;

d) habeas corpus, quando houver perigo de consumar-se violência antes que a autoridade judiciária competente dele conhecer;

e) os mandatos de segurança contra atos do Governador, dos Secretários de Estado, da Assembleia Legislativa, por sua Mesa ou Presidente, e do próprio Tribunal ou do seu Presidente; i f) as ações rescisórias de seus acórdãos;

III - processar e julgar os recursos ordinários das decisões de primeira instância;

IV - exercer as demais funções que lhe forem atribuídas por lei.

Art. 33. Os desembargadores e os juizes gozarão das garantias previstas na Constituição Federal e nas leis, sendo que os vencimentos dos primeiros serão fixados em quantia não inferior à que recebem, a qualquer título, os Secretários de Estado e os últimos, com diferença não excedente a 30\% (trinta por cento) de uma para outra entrância, atribuindo-se aos de entrância mais elevada não menos de 2/3 (dois terços) dos vencimentos dos desembargadores.

\section{TÍTULO II}

\section{Do Ministério Público}

|Art. 34. O Ministério Público do Estado, órgão da sociedade e fiscal da execução da lei, organizar-se-á em carreira, constituída de Defensores Públicos, Promotores Substitutos, Promotores Públicos eCuradores, com as garantias dos arts. 127 e 128, da Constituição Federal.

Parágrafo único. A primeira investidura nos cargos que integram as classes da carreira do Ministério Público far-se-á na inicial, por meio de concurso público, sendo que as promoções obedecerão, alternadamente, aos critérios de merecimento e antiguidade, exceção feita à classe final, quando os mesmos serão de 2/3 (dois terços) por merecimento e $1 / 3$ (um terço) por antiguidade. 
Art. 35. O Procurador-Geral, Chefe do Ministério Público do Estado, será nomeado pelo governador dentre bacharéis em Direito, com mais de 25 anos de idade, de notório saber jurídico e reputação ilibada, e que contém, pelo menos, dois anos de prática forense.

Art. 36. Aplicam-se aos membros do Ministério Público os impedimentos, vencimentos e vantagens dos magistrados.

Art. 37. O Conselho do Ministério Público, sob a presidência do Procurador-Geral, exercerá jurisdição suprema na ordem administrativa e disciplinar sobre toda a classe, e será constituída:

I - pêlos 2 (dois) curadores mais antigos;

II - por 2 (dois) membros efetivos da carreira do Ministério Público, eleitos pela maioria absoluta dos demais.

\section{TÍTULO III}

\section{Da Organização dos Municípios}

Art. 38. O Poder Legislativo, no município, é exercido pela Câmara Municipal, composta, no mínimo, de 5 (cinco) vereadores, salvo o da Capital e de Cruzeiro do Sul, que terão, pelo menos, 9 (nove) e 7 (sete)! representantes, respectivamente.

Art. 39. O Poder Executivo, no município, é exercido pelo Prefeito. Parágrafo único. O mandato do prefeito será de 4 (quatro) anos.

Art. 40. São crimes de responsabilidade dos prefeitos municipais os mencionados na Lei Federal $n^{2} 3.528$, de 3 de janeiro de 1959 .

Art. 41. São condições de elegibilidade para prefeito e vereador:

I - ser brasileiro;

II - estar no exercício dos direitos civis e políticos; 
III - ser maior de 21 (vinte e um) anos.

$\S$ I Aplicam-se aos prefeitos e vereadores os impedimentos previstos no Art. 11 desta Constituição.

$\S 2^{\circ}$ Os vereadores eleitos para as Legislaturas subsequentes não perceberão remuneração, seja a que título for. ${ }^{9}$

Art. 42. A iniciativa da lei e resolução municipal cabe a qualquer vereador e ao prefeito, sendo privativa deste a relativa à lei orçamentaria e a das que aumentem vencimentos ou criem cargos em serviços existentes.

$\S$ I Se a lei orçamentaria não for promulgada dentro de 30 (trinta) dias antes do início do exercício financeiro, ficará prorrogada a lei orçamentaria do exercício anterior.

$\S 2^{\circ}$ Aplicam-se, no que couber, aos órgãos do Executivo e Legislativo Municipal, o disposto nos Capítulos II e III, do Título I, desta Constituição.

"Somente poderão ser criados municípios novos depois de feita a prova cabal de sua viabilidade econômico-financeiro, perante a Assembleia, pela forma que for estabelecida em Lei ordinária." (Dispositivo acrescentado pelo art. $3^{\circ}$ da Emenda Constitucional n ${ }^{\circ}$ 4, de l2-12-65).

\section{TÍTULO IV}

\section{Da Organização Administrativa}

\section{CAPÍTULO I}

\section{Do Património}

Art. 43. Constituem património do Estado:

I - os bens de sua propriedade; 
9. Dispositivo acrescentado pela Emenda Constitucional no 4, de 27/10/65.

II- A divida ativa proveniente de receita não arrecadada

Parágrafo único. Os bens móveis e imóveis pertencentes ao Estado não poderão ser objeto de doação, permuta, cessão, aforamento ou alienação, senão em virtude de lei especial que prescreverá o seu processamento.

\section{CAPÍTULO II}

\section{Dos Tributos e sua Arrecadação}

Art. 44. A competência tributária do Estado e dos Municípios é a expressa nos arts. 19 e 29 da Constituição Federal, respectivamente.

Parágrafo único. A lei disporá, em Código, sobre sistema de arrecadação tributária do Estado.

\section{CAPÍTULO III}

\section{Dos Serviços e Servidores}

Art. 45. Observadas as prescrições da Constituição Federal e as desta Constituição, a lei disporá sobre a organização administrativa dos serviços do Estado e o regime jurídico de seu pessoal.

Art. 46. Além dos direitos e garantias previstos no Título VIII, da Constituição Federal, é assegurada aos servidores do Estado aposentadoria aos 30 (trinta) anos de serviço, com vencimentos integrais.

Parágrafo único. A aposentadoria com vencimentos integrais dos funcionários que exerçam atividade de magistério é garantida após 25 (vinte e cinco) anos de serviço na referida função. 
"Fica estabelecida, a partir desta data, o princípio da paridade na remuneração dos servidores dos três poderes do Estado, não admitida, de forma alguma, a correção monetária, como privilégio de qualquer grupo ou categoria." (Dispositivo acrescentado pelo art. $4^{\circ}$ da Emenda Constitucional n 4 , de $\left.1^{\circ}-12-65\right)$.

\section{TITULO V}

\section{Disposições Gerais}

Art. 47. São mantidos o hino, a bandeira, as armas e demais símbolos tradicionais do antigo Território Federal do Acre, sendo considerado feriado estadual o dia 6 de agosto, data da Revolução Acreana.

Art. 48. E criada a Polícia Militar do Estado, instituição permanente destinada à manutenção da ordem e segurança internas, sendo sua organização estabelecida em lei.

Parágrafo único. O Coronel José Plácido de Castro é o Patrono da Polícia Militar do Estado.

Art. 49. O Estado organizará o seu sistema de ensino, orientando-o de acordo com as exigências do desenvolvimento do País e da região, respeitada a Lei de Diretrizes e Bases da Educação Nacional.

Art. 50. Ao Estado cabe zelar pela saúde e bem-estar da população prestando assistência à maternidade, à infância e para os que não dispuserem de recursos, a assistência médico-hospitalar gratuita.

Art. 51. Ficam obrigados a prestar, anualmente, declaração de bens os Secretários de Estado, Auditor-Geral, Assistentes do Governador, Presidente e Diretores do Banco do Estado, Diretores de Departamentos, Chefes de Serviço, Ocupante de cargo em comissão, Presidente, Superintendente e Diretores de Autarquias, e quaisquer servidores com atribuições fiscais.

Parágrafo único. A declaração envolverá os bens do casal. 
Art. 52. O Governo assistirá e orientará técnica e financeiramente as iniciativas agropecuárias e industriais, para garantia de empreendimentos.

Art. 53. O sistema de concorrência pública é adotado nos serviços e obras do Estado e dos Municípios, de acordo com as normas estabelecidas em lei.

Art 54. Serão reservados, na emissora oficial do Estado, nos dias úteis, horários para divulgação dos trabalhos do Legislativo, Executivo e Judiciário.

55. São Municípios do Estado: Rio Branco, Cruzeiro do Sul, Sena Madureira, Tarauacá, Feijó, Xapuri, Brasiléia, Califórnia, Jordão, Marechal Taumaturgo, Porto Valter, Mancio Lima, Gregório, Assis iil, Iracema, São Francisco do Iracema, Epitácio Pessoa, Plácido Castro, Porto Acre, Manoel Urbano, Quinari, Guanabara, Santa Rosa, Reforma, São Pedro do Icó, com os limites geográficos a serem fixados em lei, e sede nas cidades, vilas ou povoados de igual nome.

Parágrafo único. Os Municípios Califórnia, Porto Valter, Gregário, São Francisco do Iracema, Epitácio Pessoa, Quinari, Guanabara, Reforma e São Pedro do Icó passam, respectivamente, a denominar-se Dimpolis, Mário Lobão, Leôncio Rodrigues, Francisco Conde, Epitaciolândia, Senador Guiomard, Avelino Chaves, Hugo Carneiro e João Câncio e Senador Passos, ${ }^{10}$

Art. 56. Serão cobradas taxas pêlos serviços efetivamente prestados ao contribuinte, ou postos à sua disposição e ainda, quando este provocar, por seu interesse ou atividade, despesas especiais do Estado.

Parágrafo único. É vedada a isenção ou redução de taxas.

Art. 57. Esta Constituição e o Ato das Disposições Constitucionais Transitórias, depois de assinados pêlos deputados presentes, serão promulgados, simultaneamente, pela Mesa da Assembleia Constituinte e l entrarão em vigor na data de sua publicação.

Sala das Sessões da Assembleia Legislativa, com função Constituinte, na cidade de Rio Branco, em 
10. Redação dada pela Emenda Constitucional no 2, de 10/12/63, que substituiu a denominação do Município de Santa Rosa por Senador Passos.

$1^{\circ}$ de março de 1963, $142^{\circ}$ da Independência, $75^{\circ}$ da República e $61^{a}$ do Tratado de Petrópolis. - Carlos Afonso, Presidente. -José Fonseca, $1^{a}$ Secretário, -Aluizio Queiroz, $2^{a}$ Secretário, Adonay Santos, Augusto Hidalgo, Benjamin de Jesus Ruella, Chaar Filho, Eloy Abud, Francisco Taumaturgo, Geraldo Reis Fleming, Guilherme Zaire, Joaquim Lopes da Cruz, Joaquim Macedo, Nabor Júnior, Ornar Sabino. 